ANDREA ALEXANDRA DO AMARAL SILVA E BIELLA

\title{
FAMÍLIAS NO MUSEU DE ARTE: LAZER E CONHECIMENTO um estudo sobre o programa educativo Interar-te do MAC USP
}

Dissertação apresentada à Faculdade de Educação da Universidade de São Paulo (FEUSP) para obtenção do título de Mestre em Educação.

Área de Concentração: Psicologia e Educação.

Orientadora: $\operatorname{Prof}^{\mathrm{a}}$. Dr ${ }^{\mathrm{a}}$. Rosa Iavelberg. 
AUTORIZO A REPRODUÇÃO E DIVULGAÇÃO TOTAL OU PARCIAL DESTE TRABALHO, EXCLUSIVAMENTE PARA FINS ACADÊMICOS E CIENTÍFICOS, SEM FINALIDADE COMERCIAL, POR QUALQUER MEIO CONVENCIONAL OU ELETRÔNICO, DESDE QUE CITADA A FONTE.

\section{Versão: original}

Biella, Andrea Alexandra do Amaral Silva e.

Famílias no museu de arte : lazer e conhecimento : um estudo sobre o programa educativo Interar-te do MAC USP / Andrea Alexandra do Amaral Silva e Biella ; orientadora Rosa Iavelberg. - São Paulo, 2012.

162 f. : il.

Dissertação (Mestrado) - - Universidade de São Paulo, 2012.

1. Educação em museus. 2. Lazer. 3. Família. I. Iavelberg, Rosa. II. Título. CDD 707

Capa e contracapa - Arte: Karen Montija \& Bruno Nunes. Imagens: Andrea Amaral Biella. 
Nome: BIELLA, Andrea Alexandra do Amaral Silva e.

Título: Famílias no museu de arte: lazer e conhecimento - um estudo sobre o programa educativo Interar-te do MAC USP.

Dissertação apresentada à Faculdade de Educação da Universidade de São Paulo para obtenção do título de Mestre em Educação.

Área de concentração: Psicologia e Educação.

Aprovado em:

Banca Examinadora

Prof. Dr.:

Instituição:

Julgamento:

Assinatura:

Prof. Dr.:

Instituição:

Julgamento:

Assinatura:

Prof. Dr.:

Instituição:

Julgamento:

Assinatura: 

A Anna Claudette, minha mãe, e Augusta, minha querida tia Gú, ambas in memorian, porém vivas em minhas lembranças e muito presentes em minha vida.

E à "minha" tia Dolores, por sempre ter me incentivado a continuar navegando...

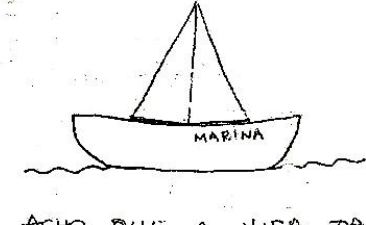

ACHO QUE A VICA DA

GENTE É COMO UM

BARCO, QUE POR MAIS

que naVEgue oNde

YA TENHA ESTADO, NUNCA OFAZ EXATAMENTE

PELO MESMO TRAJETO.

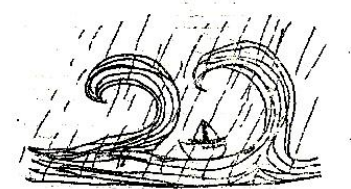

NUM DIA HŔ.

TEMPESTADE...
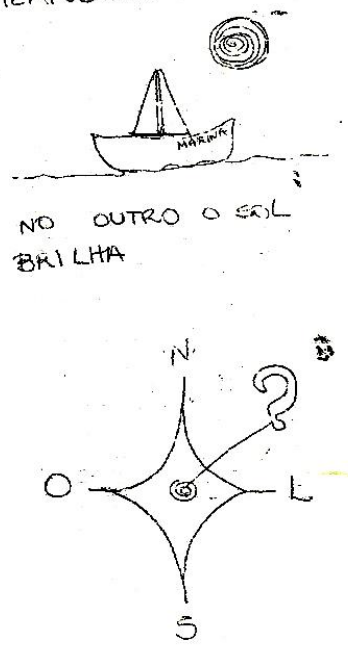

TEM DIA QUE

PERDE O RUMO

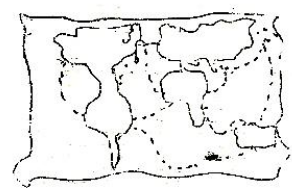

MAS NAO TEM NIMIA COMO

olhar $D$ mapa e lembrar.

de nunca ter parado

DE NANEGAR!

$$
\begin{aligned}
& \text { ANI } \\
& \text { ANDEEF. AMAPA } \\
& 26.01 .201
\end{aligned}
$$

Figura 1 - Desenho de Andrea Amaral Biella de 26/01/2001. 



\section{Agradecimentos}

A meu ver, nada se constrói ou se elabora sozinho. Meu mais sincero reconhecimento a todos aqueles que direta ou indiretamente me apoiaram na realização desta pesquisa. E em especial para:

Luiz, meu cônjuge, pela dedicação cotidiana de valor incomensurável, verdadeiro ato de amor.

Eduardo, meu filhinho, hoje com seis anos, pelas inúmeras vezes em que se viu frustrado ao solicitar, por mais da metade de sua vida: “Mamãe, brinca comigo?”. E, nos últimos meses: "Posso usar o computador?".

Prof $^{\text {a }}$. Dr ${ }^{\mathrm{a}}$. Rosa Iavelberg, da qual me orgulho do privilégio de ter tido como orientadora e mestra. Obrigada por ter transformado cada reunião de orientação e cada leitura de avaliação da pesquisa em construção em uma aula de dedicação e competência.

Prof $^{\text {a }}$. Dr ${ }^{\mathrm{a}}$. Silvia M. G. Colello, pelo aceite de minha orientação no Programa de PósGraduação da Faculdade de Educação sem qualquer contato prévio, como previsto pelo programa, e pela delicadeza em minha recepção na FEUSP.

Prof $^{\mathrm{a}}$. Dr ${ }^{\mathrm{a}}$. Belinda P. H. Mandelbaum, pela gentileza em auxiliar na elaboração da entrevista às famílias e pelo incentivo sobre a pertinência deste trabalho.

Prof ${ }^{\mathrm{a}}$. Dr ${ }^{\mathrm{a}}$. Lisbeth Rebollo Gonçalves, pelo estímulo à elaboração de novos programas educativos para a Divisão Técnico-Científica de Educação e Arte do MAC USP em sua segunda gestão como diretora do Museu.

Os professores doutores que se dispuseram a colaborar participando da banca de qualificação e de defesa dessa dissertação: Amanda Tojal, Carmen Aranha, Denise Grinspum, Katia Canton, Sumaya Mattar e Marcos Neira.

Todos os educadores assistentes que atuaram sob minha supervisão no MAC USP, pela dedicação, dinamismo e competência com a qual vivenciaram a intersecção entre a academia e o mundo do trabalho. 

A colega e grande amiga Silvana Karpinscki, responsável pelo Arquivo MAC USP, pela generosidade e maestria com que articula o contato do pesquisador com os documentos e, não menos importante, pela sensibilidade e pronto apoio, muito preciso, em meus momentos mais confusos. A Léia Cassoni, da biblioteca do Museu de Arte Moderna de São Paulo, e Monica Aliseris, da biblioteca do Museu Lasar Segall.

Todas as famílias entrevistadas, pela generosa contribuição à pesquisa e pelo cuidado na educação dos seus entes queridos.

Os amigos, pelo famoso e valioso "apoio quando mais precisamos": Anderson Tobita, Carla Augusto, Evandro Nicolau, Natália Frizzo, Paula Yurie, Pauline Martines, Ricardo Streich, Roberta Oliveira, Sara Valbon e, de novo, Silvana Karpinscki. Aos que ainda colaboraram na revisão: Paulo Marquezini, arte gráfica: Karen Montija e gráficos, Suzana Costa.

Minha família, que, talvez sem saber, me ajudou no gosto pelas exposições: primos Dinah Batista, Delma Alberti e Mauri Alberti.

Penso que as conquistas são como nos diz João Cabral de Melo Neto em "Tecendo a manhã" (1994, p.345):

Um galo sozinho não tece uma manhã: ele precisará sempre de outros galos. De um que apanhe esse grito que ele e o lance a outro; de um outro galo que apanhe o grito de um galo antes e o lance a outro; e de outros galos que com muitos outros galos se cruzem os fios de sol de seus gritos de galo, para que a manhã, desde uma teia tênue, se vá tecendo, entre todos os galos. 



\section{RESUMO}

BIELLA, Andrea Alexandra do Amaral Silva e. Famílias no museu de arte : lazer e conhecimento : um estudo sobre o programa educativo Interar-te do MAC USP. 2012, $162 \mathrm{f}$. Dissertação (Mestrado). Faculdade de Educação, Universidade de São Paulo, São Paulo, 2012.

A pesquisa "Famílias no museu de arte: lazer e conhecimento - um estudo sobre o programa educativo Interar-te do MAC USP" teve como objetivo investigar as motivações dos adultos que optam por proporcionar a crianças e jovens, nos momentos de lazer de sua família, atividades de cunho cultural e educativo e, com isso, observar os desdobramentos destas iniciativas na formação e na criação do hábito de frequentação de museus de arte de todos os envolvidos. Foi selecionado para estudo de caso o programa Interar-te do Museu de Arte Contemporânea da Universidade de São Paulo. Este programa - uma das ações de extensão universitária da Divisão Técnico-Científica de Educação e Arte do MAC USP - tem como público-alvo famílias e é realizado aos sábados, uma vez ao mês, entre janeiro e novembro; foi criado a partir de uma demanda institucional para a sede do Museu no Parque Ibirapuera, que é muito frequentado aos finais de semana pelas opções de lazer que oferece. Para compreensão do contexto da pesquisa, foram delimitados os conceitos de lazer e de família e abordados princípios sobre educação em museus de arte. Utilizou-se metodologias de análise qualitativa de pesquisa e outras informações complementares foram obtidas através de instrumentos quantitativos direcionados à amostra selecionada para estudo. Constatou-se que há influências da família de origem sobre os adultos na criação de seus hábitos de frequentação de programações artístico-culturais, assim como destes sobre suas próprias famílias, considerando-se a delimitação do perfil que a amostra representa; e, ainda, que o programa educativo Interar-te do MAC USP promove ensino e aprendizagem em artes visuais a diferentes faixas etárias e promove integração entre os membros das famílias que o frequentam.

Palavras-chave: Educação em museus. Lazer. Família. 



\begin{abstract}
BIELLA, Andrea Alexandra do Amaral Silva e. Families in the museum of art : leisure and knowledge : a study about the Interar-te Educational Program from MAC USP. 2012. $162 \mathrm{f}$. Masters Dissertation. College of Education, University of São Paulo, São Paulo, 2012.

The research "Families in the museum of art: leisure and knowledge - a study about the Interar-te Educational Program from MAC USP" aims to investigate the motivation of adults who provide their children with cultural and educational activities during their families' leisure time, in order to observe the impact of these initiatives on the habit of attending museums of art among these family members. A program called Interar-te, which is developed by the Museum of Contemporary Art of the University of São Paulo (MAC USP), was chosen for this case study. This Program, whose target audience is directed to parents and their children, is held once a month, on Saturdays, between January and November, and is one of the university extension activities provided by the Technical-Scientific Division of Education and Art of MAC USP. It was created to supply an institutional demand of the Museum's headquarters, located at Ibirapuera Park, which is a park that receives lots of visitors on weekends because of the leisure options it offers. The concepts of leisure and family were approached, and the principles related to education in art museums were approached in order to provide a better comprehension of the research context. The research was based on methodologies for qualitative research analysis, and other complementary information was collected by using quantitative tools, which were directed to the sample selected for the study. Considering the delimitation of the sample profile, we verified that families play an influential role on adults in relation to the construction of their habits of attending cultural-artistic programs, and that these habits also influence their own families. We also concluded that the Interar-te Educational Program of MAC USP promotes teaching and learning concerning visual arts for people of different ages and promotes integration among the family members who visit the Museum.
\end{abstract}

Key words: Education in museums. Leisure. Family. 



\section{LISTAS}

\section{LISTA DE ILUSTRAÇÕES}

Figura 1 - Desenho de Andrea Amaral Biella de 26/01/2001 ................................................................... 3

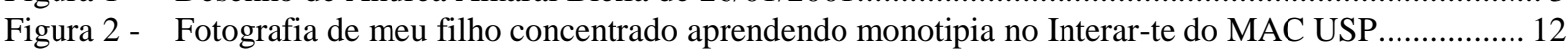

Figura 3 - Fotografia da vista do Parque Ibirapuera e da Cidade de São Paulo a partir da entrada do MAC

USP em 2007............................................................................................................... 13

Figura 4 - Fotografia do público do Interar-te construindo um inflável em oficina conduzida pelo artista

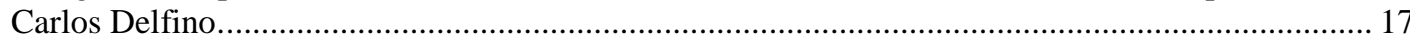

Figura 5 - Fotografia de mãe comentando os resultados do trabalho coletivo. ........................................... 39

Figuras 6 e 7 - Fotografia de menino comentando a produção, observado pela artista Renata Barros................ 39

Figura 8 - Fotografia da artista Renata Barros comentando os trabalhos realizados sob sua condução em oficina especial do Interar-te...................................................................................................... 39

Figura 9 - Fotografia da artista Renata Barros apresentando sua obra na exposição Poéticas da Natureza....... 39

Figura 10 - Fotografia de obra produzida por participante do Interarte..................................................... 42

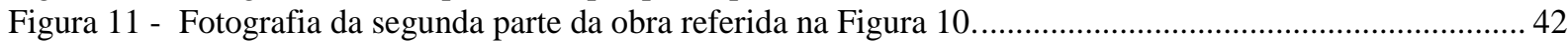

Figura 12 - Fotografia de mãe auxiliando filha num desenho de observação................................................. 45

Figura 13 - Fotografia de menina elaborando uma máscara do rosto da mãe. ............................................ 51

Figura 14 - Fotografia de carimbos criados por menino de 11 anos durante oficina do Interar-te. .....................57

Figura 15 - Fotografia de criança de 4 anos explicando trabalho coletivo em oficina especial do Interar-te....... 65

Figura 16 - Mapa da cidade de São Paulo indicando o bairro de residência dos entrevistados adultos na época da participação no programa educativo Interar-te.................................................................... 74

Figura 17 - Desenho de menino de 8 anos da família 4 ............................................................................. 112

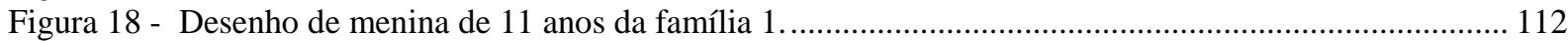

Figura 19 - Desenho de menino de 6 anos da família 5 ........................................................................... 113

Figura 20 - Segundo desenho do menino de 6 anos da família 5 ............................................................ 113

Figura 21 - Desenho do menino de 6 anos da família 10 representando o gesto de macerar pigmento............ 114

Figura 22 - Fotografia do menino referido na Figura 21, sua mãe e uma prima. ....................................... 114

Figura 23 - Fotografia do menino referido na Figura 21, utilizando a tinta que ele preparou na oficina. .......... 114

Figura 24 - Fotografia de jovem de 18 anos estampando camiseta em oficina do Interar-te. ........................ 121

Figura 25 - Fotografia de participantes da oficina especial do Interar-te com a artista Paola Parcerisa............ 127

Figura 26 - Fotografia de criança explorando a câmera escura que construiu em oficina do Interar-te. ........... 131

As fotografias apresentadas neste trabalho são de autoria da pesquisadora.

\section{LISTA DE QUADROS}

Quadro 1: Qualificação (no âmbito da pesquisa) das famílias entrevistadas................................................. 70

Quadro 2: Perguntas feitas às famílias diante das 3 questões centrais da pesquisa a serem investigadas ............ 77

Quadro 3: Atividades de lazer dos 13 adultos na infância e adolescência - relatadas espontaneamente. ............. 77

Quadro 4: Atividades de lazer dos 13 adultos na infância e na adolescência, por categoria (local de

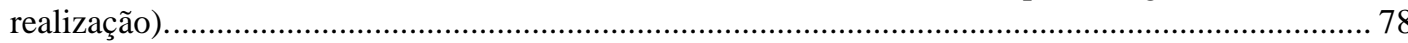

Quadro 5: Primeiro contato dos adultos com a arte em geral, por modalidade. ............................................ 79

Quadro 6: Atividades de lazer dos 13 adultos na atualidade - relatadas espontaneamente................................ 83

Quadro 7: Atividades de lazer dos 13 adultos na atualidade, por categoria (local de realização) .......................83

Quadro 8: Atividades de lazer das 12 famílias na atualidade - relatadas espontaneamente.............................. 88

Quadro 9: Atividades de lazer das famílias na atualidade por categoria (local de realização)........................... 89

Quadro 10: Conduta dos entrevistados adultos, pais das crianças e jovens, sobre atividades escolares extraclasse..

Quadro 11: Conduta dos entrevistados adultos, pais das crianças e jovens, sobre os produtos culturais que os

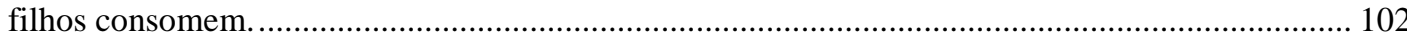

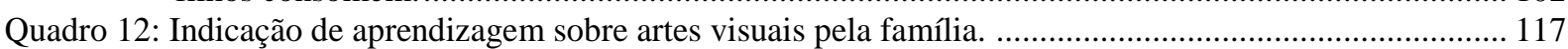

Quadro 13: Indicação de programações da família além do Interar-te nos dias que o frequentaram. Houve indicação de mais de um fator por família. 



\section{LISTA DE GRÁFICOS}

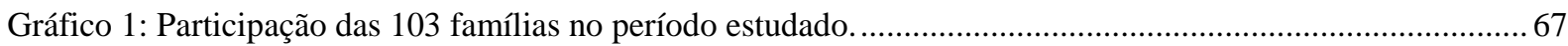

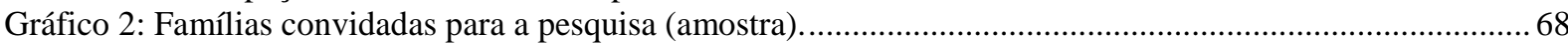

Gráfico 3: Famílias entrevistadas diante do total que participou do Programa Interar-te....................................68

Gráfico 4: Número de vezes que cada família entrevistada participou do Interar-te no período estudado............6 68

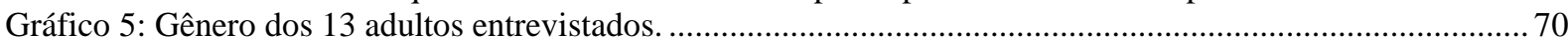

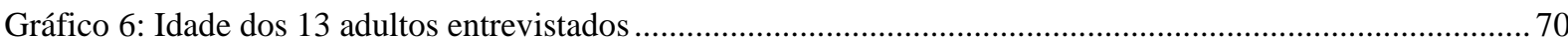

Gráfico 7: Gênero das crianças (5 a 12 anos - idade por ocasião da entrevista) ........................................... 71

Gráfico 8: Gênero dos jovens (13 a 21 anos - idade por ocasião da entrevista)............................................ 71

Gráfico 9: Rede de ensino das escolas de educação básica onde estudam ou estudaram as 17 crianças e jovens. 71

Gráfico 10: Nível de escolarização dos 13 adultos entrevistados .................................................................72

Gráfico 11: Tipo de vínculo dos 13 adultos com as crianças e adolescentes................................................. 72

Gráfico 12: Classificação econômica dos agrupamentos familiares............................................................73

Gráfico 13: Distância em quilômetros entre o bairro em que moram ou moravam os adultos das 12 famílias..... 73

Gráfico 14: Meio de transporte utilizado pelas famílias para irem ao MAC USP no Parque Ibirapuera. .............75

Gráfico 15: Formas de contato inicial com a arte em geral, indicadas pelos adultos, por modalidade ................. 79

Gráfico 16: Grau de parentesco dos familiares responsáveis pelo primeiro contato com a arte...........................80

Gráfico 17: Indicação de fator que desenvolve o gosto pela cultura. ............................................................. 82

Gráfico 18: Acompanhante(s) dos entrevistados em seu lazer atual. ........................................................... 87

Gráfico 19: Indicação sobre quem opta pelas atividades de lazer das famílias. ..............................................93

Gráfico 20: Critério de seleção das atividades de lazer das famílias. ..........................................................93

Gráfico 21: Meio de divulgação consultado sobre programações para a família. ............................................94

Gráfico 22: Frequência a exposições de arte em viagens. ....................................................................95

Gráfico 23: Existência de instituição cultural próxima à residência dos adultos..............................................96

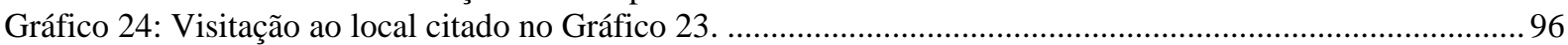

Gráfico 25: Visitação de adultos a exposições de arte sem a companhia de crianças e jovens. ...........................97

Gráfico 26: Exposição visitada pelos adultos que lhes foi mais significativa, por modalidade (local). ...............97

Gráfico 27: Exposição mais significativa para as crianças e jovens, por família, por modalidade (local). ...........98

Gráfico 28: Frequência anual das crianças e jovens a exposições de arte com a escola, por família. ..................98

Gráfico 29: Frequência anual das crianças e jovens a exposições de arte com a família, por família..................98

Gráfico 30: Frequência anual a exposições de arte das famílias que declararam frequência maior ou igual a 3...99

Gráfico 31: Preferência de crianças e jovens sobre práticas culturais para realizar na companhia de adultos.... 102

Gráfico 32: Opinião comparativa das crianças e jovens sobre visitar exposições com a família e com a escola.103

Gráfico 33: Preferência de 7 crianças e jovens entre ir a exposições com a escola e com a família. ................. 103

Gráfico 34: Motivos indicados pelos adultos para frequentarem o Interar-te............................................... 104

Gráfico 35: Modo de conhecimento do programa Interar-te. ................................................................... 107

Gráfico 36: Membro da família que optou por participar do Interar-te. ......................................................... 107

Gráfico 37: Justificativa dos adultos sobre não participar mais vezes do Interar-te....................................... 114

Gráfico 38: Justificativa dos adultos para a reincidência na participação da família no Interar-te..................... 116

Gráfico 39: Famílias que indicaram o Interar-te para conhecidos. ......................................................... 116

Gráfico 40: Indicação de participação no Interar-te caso a atividade não fosse gratuita. ................................. 116 



\section{SUMÁRIO}

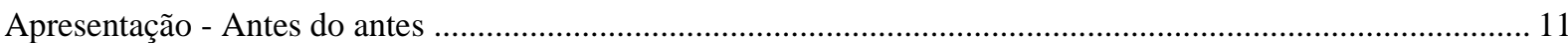

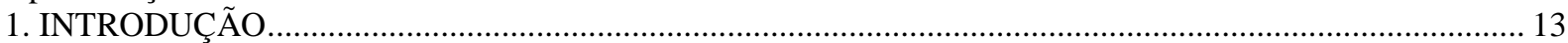

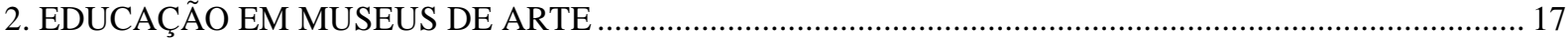

2.1. Breves considerações sobre educação em museus .................................................................... 19

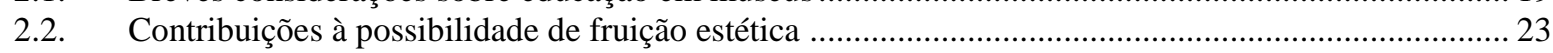

2.3. Educação no Museu de Arte Contemporânea da Universidade de São Paulo.....................................29

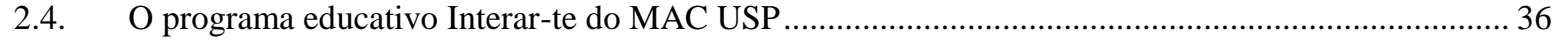

2.5. Programas educativos para famílias em museus de arte ............................................................ 43

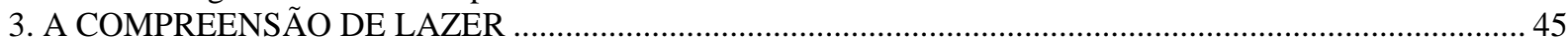

3.1. Tempo humano de trabalho e de não trabalho: localizando as atividades de ócio .................................47

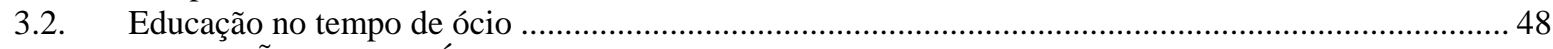

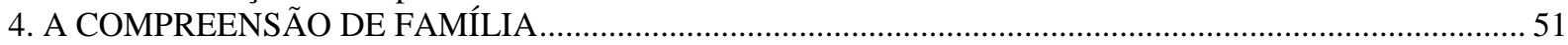

4.1. A família em atividade de ócio em um museu de arte ...............................................................5 53

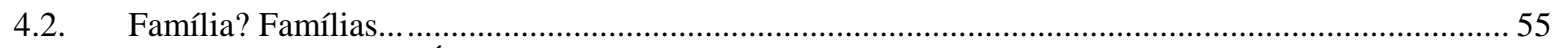

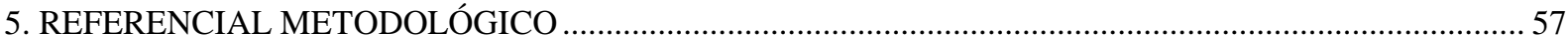

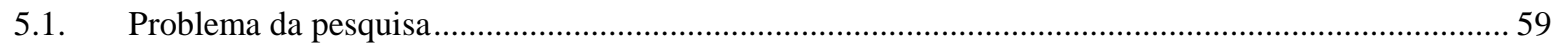

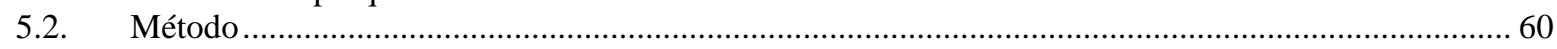

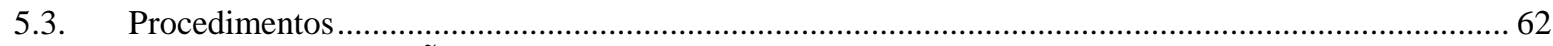

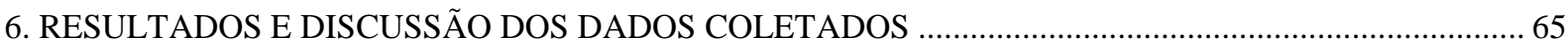

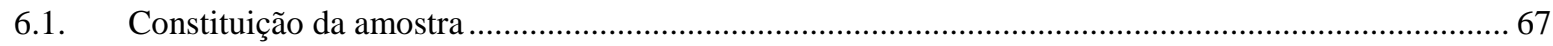

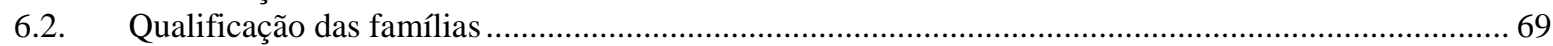

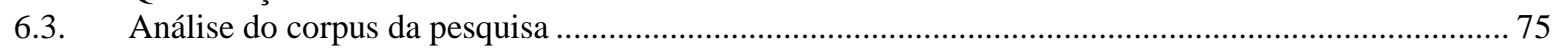

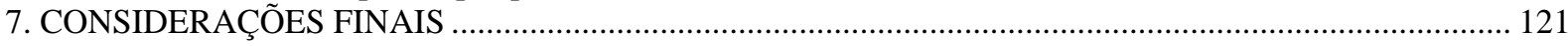

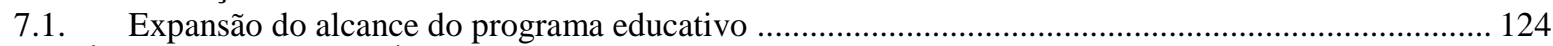

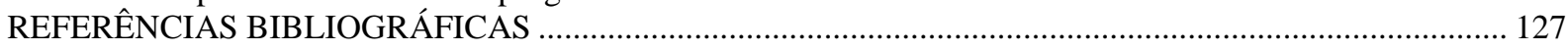

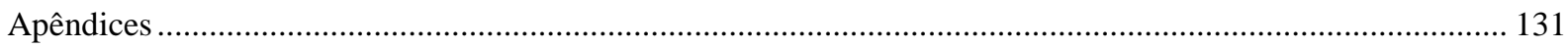

Apêndice 1 - Entrevista semiestruturada aos agrupamentos familiares ................................................. 133

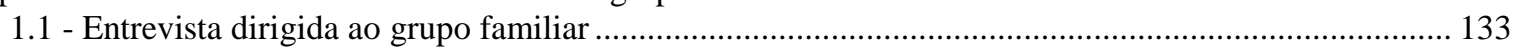

1.2 - Desenhos solicitados às crianças como instrumento de apoio e comentários da pesquisadora .......... 135

Apêndice 2 - Questionário fechado sobre índice de classificação econômica dos agrupamentos familiares.. 137

Apêndice 3 - Dados da equipe de educadores assistentes (bolsistas e estagiários) do programa Interar-te

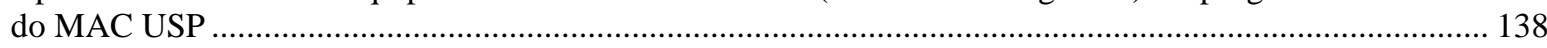

3.1 - Relação de atividades do período em estudo nos quais atuaram..................................................... 138

3.2 - Questionário aberto aos educadores assistentes (antes da entrevista por grupo focal) ..................... 140

3.3 - Planejamento da entrevista por grupo focal ......................................................................... 141

3.4 - Transcrição da entrevista por grupo focal.................................................................................. 142

Apêndice 4 - Transcrição de entrevista semiestruturada da Prof ${ }^{\mathrm{a}}$. Dr ${ }^{\mathrm{a}}$. Lisbeth Rebollo Gonçalves,

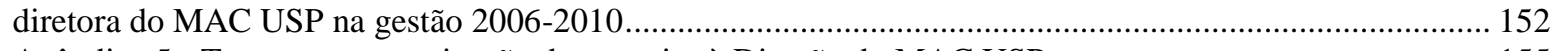

Apêndice 5 - Termo para autorização de pesquisa à Direção do MAC USP …......................................... 155

Apêndice 6 - Termo de consentimento livre e esclarecido dos agrupamentos familiares ............................. 156

Apêndice 7 - Termo de consentimento livre e esclarecido de ex-estagiários ou ex-bolsistas do programa

Interar-te do MAC USP ......................................................................................................... 158

Apêndice 8 - Termo de consentimento livre e esclarecido da ex-diretora do MAC USP (gestão 2006-

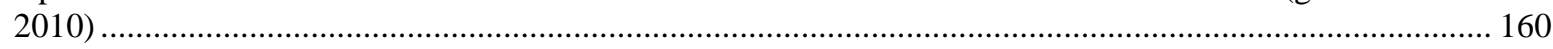

Apêndice 9 - Termo de autorização de uso de imagem de artista ministrante de oficina em sessão especial do programa educativo Interar-te do MAC USP ................................................................. 162 



\section{Apresentação - Antes do antes}

Não me lembro de ir com meu pai a exposições. Íamos muito a restaurantes e viajávamos. Quando criança, morei por um período com tios e os meus primos me levavam ao circo, ao SESC Pompeia e ao cinema, além das muitas matinês de carnaval. Depois, por iniciativa de minha primeira madrasta, fui matriculada numa escola de arte, por volta dos 15 anos. O ensino de arte nessa escola famosa em São Paulo era muito técnico e visava produtos vistosos, mas lá conheci um pouco de história da arte que a escola formal não me apresentou. No colégio eu produzi objetos artesanais, adquiri trauma em me expor em atividades cênicas e, em música, não passei da desafinada Asa Branca mal tocada na flauta doce.

$\mathrm{Na}$ escola de arte eu conheci vários "ismos", apesar de não entender o porquê das propostas práticas que geravam e aprendi que podia entrar em galerias de arte e ousar pedir um catálogo mesmo aparentando não ser compradora. Por ocasião de um trabalho para essa escola, fui pela primeira vez a uma Bienal de São Paulo, em 1989, aos 17 anos.

Ah, a Bienal... Não entendi muito de tanta coisa, mas me encantei com um torso masculino, enigmático pelo halo de luminosidade que o pigmento de uma só cor que o cobria deixava emanar, uma coisa, a meu ver naquela época, inexplicável pela arte; talvez só a física, aliada à química, desse conta: parecia que o volume da obra era expandido em quase dois centímetros em algo que não era matéria; uma luz sem energia elétrica, simples cor do pigmento! Claro que meu trabalho sobre a visita à Bienal foi sobre esse artista. Recortei todinho o catálogo que comprei para ilustrar meu texto datilografado... Arrependo-me até hoje por essa destruição, mas foi assim que me apaixonei pelo azul de Yves Klein, na época um artista sem nome para mim, apenas o "cara" que havia me encantado pela luminosidade enigmática do torso azul.

Ir a exposições em galerias e museus ou apenas entrar no SESC era o conforto para as angústias juvenis, um refúgio introspectivo onde a melancolia promovia encontros equilibradores e reconfortantes comigo mesma, entre quem eu era e aquela pessoa que eu queria um dia vir a ser.

Acho que por isso resolvi ser educadora na área de arte: arte por ser o campo onde o esquisito, o estranho e o não compreendido muitas vezes representam possibilidades saudáveis de existência, mesmo que reconhecidas postumamente; e um lugar, sem dúvida, onde se pode deparar inesperadamente com o encantamento. Nesse lugar, o tempo que nos impõem ou que absorvemos cotidianamente sem saber como administrar pode ser suspenso. E educadora para poder compartilhar o sentido dessa experiência, para poder fazer o maior 
número possível de pessoas acreditarem que as incertezas podem nos mover positivamente e que a arte pode produzir conforto e confronto nesses e em outros momentos. Para fazê-los acreditar na possibilidade de convivência com as dores e as angústias, principalmente quando o que temos de sólido é apenas o agir íntegro num mar de dúvidas mas, também, propulsor.

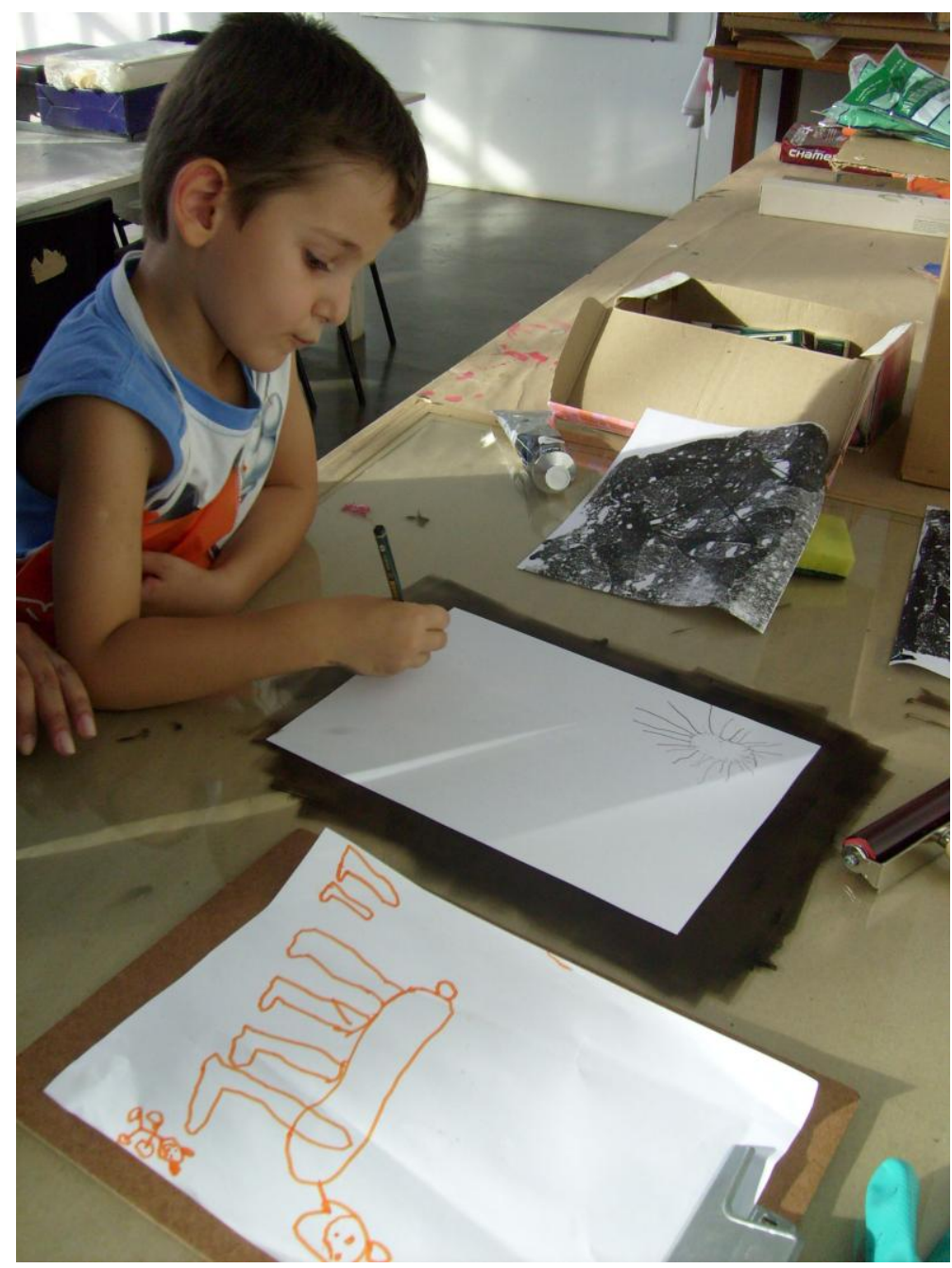

Figura 2 - Meu filho, muito concentrado ao aprender monotipia, participando do Interar-te do MAC USP com a idade mínima recomendada (5 anos), embora fosse frequentador desde os 2 anos; muitas vezes me acompanhou involuntariamente ao trabalho aos finais de semana. 


\section{INTRODUÇÃO}

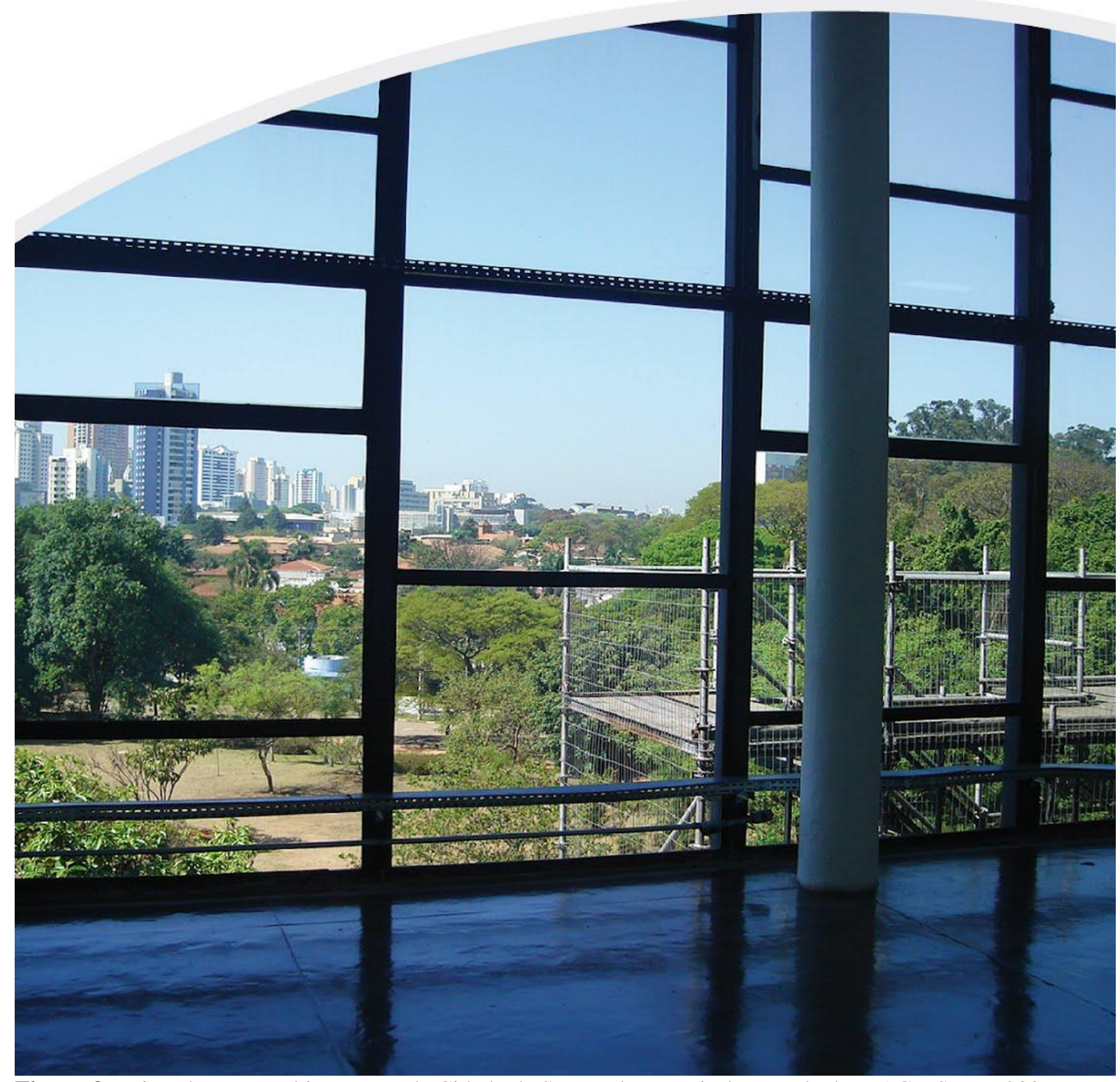

Figura 3 - Vista do Parque Ibirapuera e da Cidade de São Paulo a partir da entrada do MAC USP em 2007. 


\section{INTRODUÇÃO}

Existem várias maneiras de aprender as coisas. A mais convencional delas é a do discurso pedagógico, a fala organizada que pretende nos ensinar o que precisamos saber. Mas aquela que nos marca de modo mais profundo e duradouro é sempre a da observação do gesto do outro, o exemplo do qual somos testemunhas e cujo significado reconhecemos visceralmente.

Cacá Diegues ${ }^{1}$

Esta pesquisa tem como objeto de investigação as motivações (a origem, o passado, o que os mobiliza no presente) e as aspirações (o que esperam com ações que contribuem à educação) de adultos que, nos momentos de lazer, propiciam a seus familiares crianças e adolescentes atividades de cunho cultural e educativo.

Para estudo de caso foi selecionado o programa educativo Interar-te, que é uma das ações de extensão universitária ${ }^{2}$ do Museu de Arte Contemporânea da Universidade de São Paulo e tem como público-alvo famílias. Educação e divertimento estão presentes sem conflito nas estratégias educativas desenvolvidas no Interar-te, mas cabe perguntar se é função de um museu propiciar atividades com o caráter de lazer. O International Council of Museums (ICOM), em seus estatutos, define museu como:

(...) uma instituição sem fins lucrativos, permanente, a serviço da sociedade e de seu desenvolvimento, e aberta ao público, que adquire, conserva, pesquisa, divulga e expõe, para fins de estudo, educação e o divertimento, testemunhos materiais do povo e seu meio ambiente. ${ }^{3}$

Sendo assim, o MAC oferece atividades de extensão cultural que abrangem programas educativos dessa natureza. No Interar-te é objetivo geral o aprimoramento da qualidade das relações familiares, além dos objetivos específicos relacionados ao ensino de artes visuais no âmbito da educação não-formal.

Para a investigação proposta foram utilizadas metodologias de análise qualitativa de pesquisa e outras informações complementares foram obtidas através de instrumentos quantitativos direcionados à amostra selecionada para estudo.

\footnotetext{
${ }^{1}$ Cacá Diegues. In (COLOMBINI, 2006, p.5).

${ }^{2} \mathrm{O}$ estatuto da Universidade de São Paulo prevê ações sob três grandes eixos: ensino, pesquisa e extensão universitária. Este último é o eixo de ações destinadas à comunidade em geral.

${ }^{3}$ Definição de museu do artigo $2 \S 1$ do Estatuto do Conselho Internacional de Museus (ICOM) disponível em: <http://www.revistamuseu.com.br/legislacao/museologia/eticaicom.htm>. Acesso em 05/04/2011.
} 


\section{EDUCAÇÃO EM MUSEUS DE ARTE}

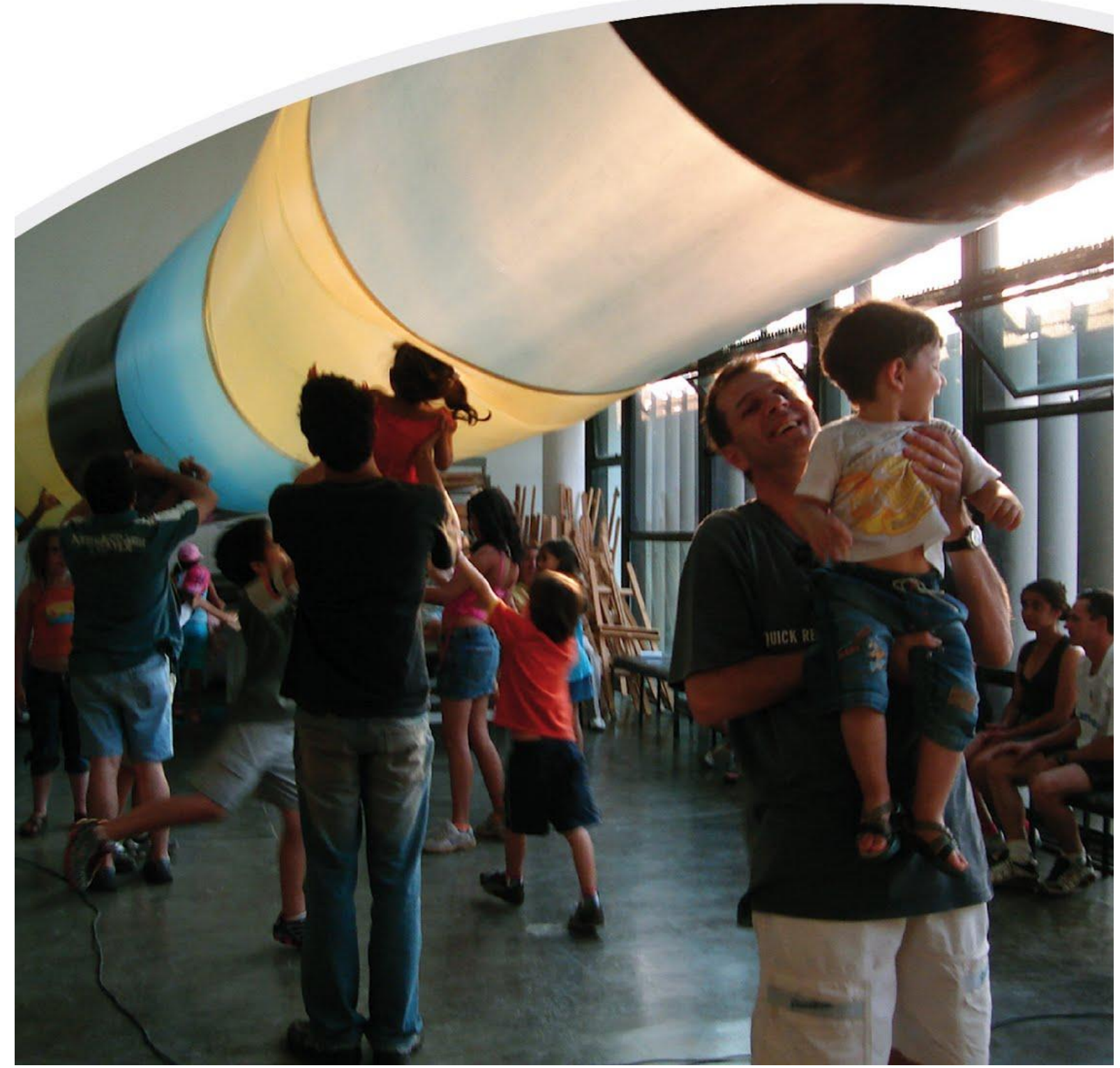

Figura 4 - Público do Interar-te constrói um inflável em oficina conduzida pelo artista Carlos Delfino, em 12 de outubro de 2007. 


\section{EDUCAÇÃO EM MUSEUS DE ARTE}

\subsection{Breves considerações sobre educação em museus}

Quadro nenhum está acabado, disse certo pintor; se pode sem fim continuá-lo, primeiro, ao além de outro quadro que, feito a partir de tal forma, tem na tela, oculta, uma porta que dá a um corredor que leva a outra e a muitas outras.

João Cabral de Melo Neto ${ }^{4}$

Em sua palestra inaugural ao Congresso Poéticas e Políticas da Natureza do Programa de Pós-Graduação Interunidades em Estética e História da Arte (PGEHA-USP), em 2008, o Prof. Dr. Ulpiano Toledo Bezerra de Meneses (FFLCH-USP) discorreu sobre a importância do museu à sociedade contemporânea. Ulpiano considera que, num tempo em que a rapidez vigora e o ritmo da vida, principalmente nos grandes centros urbanos, é acelerado, o comportamento humano parece querer competir com as mudanças tecnológicas, sobretudo as relacionadas à informática e à obsolescência dos bens de consumo. Nesse contexto, o museu, por excelência, é o local em que se pode ter uma experiência única, que envolve os sentidos. Mas para que essa experiência se estabeleça é uma exigência a disponibilidade para a percepção e a vivência de outra relação temporal - a de um tempo que não é o do cotidiano em grandes cidades nem o da tecnologia, mas o necessário para o fruidor se relacionar com objetos que, com a cautela que exigirão, poderão fazê-lo indagar sobre o que ali se apresenta e representa. Esta relação que não é a habitual no cotidiano poderá lhe fazer sair do museu com mais perguntas do que respostas, tudo o que é evitado corriqueiramente, quando mensagens curtas e notícias bombásticas nos meios de comunicação de massa substituem o envolvimento das pessoas com as coisas da vida. (informação verbal) ${ }^{5}$

Podemos complementar esta percepção da importância da frequentação de museus com a reflexão da psicanalista Maria Rita Kehl sobre a modernidade, mas que pode ser compreendida na atualidade:

\footnotetext{
${ }^{4}$ A Lição de Pintura, in: (MELO NETO, 1994, p.401).

${ }^{5}$ Informações fornecidas por Meneses no Congresso Poéticas e Políticas da Natureza em 2008.
} 
(...) $\mathrm{O}$ heroísmo de Baudelaire não consiste em se fazer defensor da multidão fascinada e consumida pelas mercadorias e pelo trabalho braçal que a aproxima e afasta do brilho das mercadorias. Consiste apenas, o que já é muito, em descrer de tal fascínio. (KEHL, 2009, p. 75)

No entanto, não basta entrar no espaço físico do museu para vivenciar essa experiência única. Grande parte da população de uma cidade como São Paulo sequer reconhece esse tipo de instituição como uma das possibilidades de lazer ou mesmo que tem o direito de conhecêlo, ainda que o ingresso seja gratuito, como demonstram pesquisas com público de grandes mostras de arte; ou seja, estas pessoas não veem sentido no usufruto de bens patrimoniais em instituições dessa natureza e quando vivenciam a experiência de visitação a um museu não se reconhecem nestes locais. Em contrapartida, em relação ao público frequentador de exposições em museus, questiona-se qual a qualidade de sua visitação. Sobre o público visitante do Museu do Louvre, o filósofo francês Jean Galard, em entrevista concedida a Martin Grossmann no sítio Fórum Permanente ${ }^{6}$, comenta:

Em relação ao público, permanece esse fenômeno fundamental da dificuldade na relação com as obras, porque todas estão chamando a atenção ao mesmo tempo. $\mathrm{O}$ público está um pouco disperso de maneira totalmente inevitável, eles não olham nada, passam pelas obras e dão uma olhada de dez segundos. (GROSSMANN \& MARIOTTI, 2011, pp.127-8)

Galard, que foi diretor cultural do Louvre e é também conhecedor de instituições no Brasil, trata de sua experiência em um museu de grande visitação em que muitos turistas ávidos por estarem naquele espaço percorrem-no sem se aterem à qualidade da experiência e à crítica do que ali se apresenta. A reflexão do museólogo Marcelo Araújo, diretor da Pinacoteca do Estado de São Paulo sobre para quem se fazem museus, corrobora com a ideia:

Os museus existem para a população como um todo.

Essa é uma visão fundamental, que os museus devem ter hoje em dia. O museu tem que ser voltado à toda a sociedade. No entanto, estamos falando de segmentos que são absolutamente diferenciados em termos de formação e de necessidades, o que nos leva, entrando em questões mais técnicas, à busca de ações específicas para esses diferentes públicos, seja do ponto de vista das necessidades, da faixa etária, da formação e da compreensão. Mas se o museu não tiver essa visão e não se preparar para isso, ele corre um altíssimo risco de se isolar e perder a sua função social. (GROSSMANN \& MARIOTTI, 2011, p. 139)

Nessa esteira de pensamentos apontamos a importância social dos setores educativos dos museus e instituições culturais. Se apenas adentrar um museu não é garantia do acesso a uma experiência estética de qualidade ou à fruição dos bens patrimoniais que ali se apresentam, é preciso buscar elementos que ajudem esse acesso, tais como: reconhecer este espaço; sentir necessidade de entrar para usufruir do que ali é apresentado sob a forma de

\footnotetext{
${ }^{6}<$ www.forumpermanente.org>.
} 
exposições e ações para o público; ver sentido em estar nesse lugar, ver-se ali representado, por questões de identidade ou de alteridade; sentir-se desafiado a duvidar e a conhecer; e sentir-se confortável, ter uma estada prazerosa e, por que não?, divertir-se. O que não se pode permitir é que o visitante, principalmente aquele que não tem o hábito, tenha a sensação de exclusão num mar de construções museológicas e museográficas que fazem o não frequentador assíduo se perceber diminuído e desqualificado e que ao invés de motivá-lo em buscar conhecimento pode torná-lo incapaz de se interessar-se por essa parcela da cultura de seu povo.

Deve-se, portanto, considerar a qualidade da relação do indivíduo com objetos e com um espaço que o desloca do mundo exterior e que, por isso mesmo, pode ou não promover uma experiência que o estimule a questionamentos, ao conhecimento e à fruição estética.

\footnotetext{
A fruição da arte não é imediata, espontânea, um dom, uma graça. Pressupõe um esforço diante da cultura. Para que possamos emocionar-nos, palpitar com o espetáculo de uma partida de futebol, é necessário conhecermos as regras desse jogo, do contrário tudo nos passará desapercebido, e seremos forçosamente indiferentes.

(...). A arte, no entanto, exige um conjunto de relações e de referências muito mais complicadas. Pois as regras do jogo artístico evoluem com o tempo, envelhecem, transformam-se nas mãos de cada artista. Tudo na arte - e nunca estaremos insistindo bastante sobre esse ponto - é mutável e complexo, ambíguo e polissêmico. Com a arte não se pode aprender "regras" de apreciação. E a percepção artística não se dá espontaneamente. (COLI, 1990, pp.115-116)
}

O setor educativo de um museu pode contribuir para a iniciação do conhecimento sobre artes visuais pelo público em geral, não especializado, promovendo experiências e auxiliando-o na construção de repertório.

No Interar-te, o programa educativo selecionado como estudo de caso deste trabalho, uma das condições de participação é que esteja presente a família, ou parte dela - sem a condução de adultos, os menores não participariam das sessões. Sob essa premissa surgiram as questões, ainda a serem investigadas, sobre quem escolhe a programação de lazer das famílias e se são os adultos os responsáveis pela iniciação do gosto pelas artes visuais nas crianças. A formação do hábito, porém, é determinada pelo significado que os sujeitos atribuem à experiência; afinal, memória é aquilo que se seleciona dos acontecimentos, então, mesmo que por muitos anos uma pessoa fique sem voltar a realizar uma atividade em sua vida, ela pode vir a retomá-la. O psicólogo húngaro Mihaly Csikszentmihalyi (1999, p. 25) aponta que "(...) embora o que fazemos todo dia tenha muito a ver com o tipo de vida que levamos, o modo como experimentamos o que fazemos é ainda mais importante". 
Para esta pesquisa, interessa investigar o que leva adultos a buscarem uma opção de lazer num museu de arte. A visitação a exposições de artes plásticas estaria em suas experiências da infância com a família de origem ou, talvez, de suas relações sociais posteriores? De qualquer modo, a qualidade da experiência no museu é fator importante para o acesso voluntário continuado de frequentação de exposições pelo público.

Ao participar do programa Interar-te, além de promover esta vivência às crianças, os adultos também participam e se transformam. As atividades não são mecânicas, não visam a aprendizagem de procedimentos técnicos, mas o modo, utilizado pelos artistas, de materializar ideias, percepções, questionamentos, provocações. A convivência é valorizada e estimulada, assim como a troca de opiniões, de papéis - muitas vezes adultos, crianças e adolescentes discutem seus trabalhos como colegas, como iguais, apesar de suas diferenças. Ou seja, investe-se na qualidade da experiência no museu - não só do contato com a arte, mas da relação que se estabelece entre visitantes, familiares, a equipe de educadores e demais grupos que se encontram neste espaço, que é institucional. O objetivo da pesquisa é conhecer o perfil do público adulto que frequenta um museu com a família em busca de lazer assim como o impacto dessas ações na qualidade das relações e vínculos no interior de cada família. Porém não há dúvidas de que nesse ínterim promove-se conhecimento sobre arte. Afinal, o que move o programa são as exposições em cartaz no Museu de Arte Contemporânea, instituição que abriga mostras de arte moderna e contemporânea tanto de seu acervo quanto de demais procedências (colecionadores, outras instituições públicas ou privadas, artistas, etc.).

Segundo Vygotsky (1989, pp. 265-277), para a psicologia a atividade é uma reação do sujeito mediada pelo reflexo psíquico, mas não é uma reação corporal (um reflexo, instinto, algo fisiológico); é um sistema que tem estrutura, trânsito e transformações internas, tem desenvolvimento. A atividade não pode ser examinada desvinculada das relações sociais, da vida da sociedade. Ela representa um sistema, incluindo os sistemas de relações da sociedade, sem as quais não existe.

Estabelecendo uma relação entre esta compreensão de atividade e atividades do Programa Interar-te, entendemos que a proposição se dá no sentido mediador-público: o educador do museu é o proponente de uma situação específica, com objetivo de difundir conhecimento em artes visuais, abordados por meio de diferentes estratégias e de promoção da integração familiar por intermédio da cultura. As relações sociais promotoras da atividade estão presentes tanto no âmbito da educação não-formal, no qual se insere a especificidade da Divisão Técnico-Científica de Educação e Arte do Museu, quanto da informal, que visa 
promover trocas de experiências e vivências entre os participantes de um mesmo agrupamento familiar, seja ele nuclear ou não.

No entanto, Vygotsky aponta que "a sociedade produz a atividade dos indivíduos que a formam" (1989, p.266). Em menor grau de complexidade, aproximando esta afirmação da realidade institucional do MAC USP, perguntamos em que medida o vínculo entre atividades e exposições em cartaz é promotor de formação e conhecimento em artes visuais. E, ainda, qual a política institucional que permite certas mostras e recusa outras, às quais as atividades educativas estão subordinadas? Não entraremos no mérito dessa questão, mas certamente obras expostas no museu são avalizadas como "arte" pelos especialistas que a escolheram. A responsabilidade dos curadores, através de suas pesquisas, é fundamental; não incorreriam em chancelar produções de baixa qualidade. Porém há que se considerar que muita produção de qualidade fica de fora do circuito institucional da arte.

\subsection{Contribuições à possibilidade de fruição estética}

O mais difícil, mesmo, é a arte de desler.

Mário Quintana ${ }^{7}$

Qual o papel da arte na vida do ser humano? Questão intrigante que cientistas e filósofos, entre outros, buscam compreender a ponto de estudarem as sinapses do cérebro que levaram à produção simbólica, também presentes nas manifestações que, hoje, chamamos de artísticas. A partir de um certo ponto da existência, a produção simbólica estabeleceu uma diferenciação de comportamento de nossa espécie em relação a outras. Daí em diante, nunca deixou de ser realizada em todas as culturas. O antropólogo português José Antônio B. Fernandes Dias, ao tratar do significado da produção simbólica artística, diz:

Tudo isto aponta para uma concepção da prática artística, na criação e na recepção, como um modo humano e universal de relação com o mundo. Victor Turner distingue-o do da vida quotidiana e da esfera do trabalho, que são o domínio da adaptação racional a meios e fins, da operação invariante das relações de causaefeito, da racionalidade, do senso comum; e que designa por "modo indicativo da cultura". As artes, diferentemente, pertencem ao "modo subjuntivo ou conjuntivo da cultura" - o domínio do como se, da hipótese, da fantasia, da conjectura, do desejo; quando as estruturas da experiência são analisadas e os seus factores recombinados, mais ou menos ludicamente, com mais ou menos liberdade; explorando sempre, em maior ou menor grau, a variação e a experimentação, para suspender a realidade pragmática e simbolizar num vínculo material uma outra realidade. (1994. p.196)

\footnotetext{
${ }^{7}$ Para perceber a arte, In: (QUINTANA, 2007, p.33).
} 
Qual a importância, então, do ensino de arte? Por que ensiná-la? Pragmaticamente, há que se reconhecer a importância da educação visual numa sociedade altamente povoada por imagens como é a ocidental. Em entrevista a Martin Grossmann em 2005, Marcelo Araújo argumenta:

(...) No mundo de hoje, o museu é fundamental, devido a processos culturais cada vez mais complexos e de uma certa maneira frágeis. Há principalmente a questão da educação do olhar. Farei uma comparação que é politicamente paradigmática: dez anos atrás, no Brasil, a condição necessária para o voto, para o exercício da cidadania, era você ser alfabetizado. Hoje em dia, essa condição não é mais exigida, porque o voto é efetuado através de um computador no qual aparece a fotografia dos candidatos, e a leitura é, portanto, visual. É fundamental entender que uma imagem não é desprovida de valor; ele não é o dado de uma realidade pura, mas é uma construção, e um dado que foi construído pode ser manipulado. Essa é uma questão de educação do olhar, e o uso da arte tem um papel fundamental nesse processo. Quando lembramos das grandes linguagens que surgiram e se consolidaram no século XX como a fotografia, o cinema, o videoclip e a publicidade, elas têm a característica comum de serem linguagens que trabalham com a visualidade, muitas vezes acelerando à velocidade um número incomensurável de imagens. Na verdade, o museu de arte tem a capacidade de educar o olhar dos visitantes para que eles possam entender esse processo de formação de imagens e cidadania na sociedade contemporânea. Se não tivermos o olhar preparado para ver como as imagens podem ser construídas e quais são seus significados ficamos praticamente entregues ao universo das imagens, sem uma condição de exercício real da cidadania. Portanto, o museu tem um sentido político, que eu considero fundamental, e um sentido mais amplo, a construção dos significados essenciais para a formação da personalidade e para a criação de valores. (GROSSMANN, 2011, pp.138-9)

A educação do olhar para uma percepção crítica de imagens apresentadas pela mídia é de fato importante. Porém, para além da arte como conhecimento e como instrumento capaz de habilitar o ser humano a ter consciência de que muitas imagens são manipuladas no intuito da indução de comportamentos, sejam eles do consumo de bens materiais, alteração de modos de agir ou pensar, o contato com a educação em arte pode devolver-lhe a consciência da importância de algo que lhe é inerente à existência: a necessidade de relação simbólica com o mundo. Um ensino de arte que contemple o conhecimento de manifestações artísticoculturais, o experienciar respostas múltiplas, complementares e não excludentes, diante dos mesmos desafios e que favoreça a convivência, o respeito à diferença, não apenas de sua aceitação.

Desse modo estamos apontando aspectos e objetivos do ensino de arte (habilitar a viver e conviver com as imagens do mundo contemporâneo); mas o ensino de arte pode, ainda, propiciar a construção de repertório que leve os sujeitos à fruição estética. A fruição é mais ampla, alcança o impalpável, o não mensurável. Discorrendo sobre as transformações acerca da compreensão do que pode ser considerado arte, enfatizando as grandes mudanças trazidas pela arte moderna, Dias aponta: 
O breve esboço do estado da arte hoje era indispensável para pensar esta questão. Ele permite evitar o erro fácil de reduzir a educação artística ao domínio de técnicas, e à formação do gosto, à aprendizagem de princípios estéticos, segundo uma bipolarização tradição/modernidade, para a manter ou para a ultrapassar; como se a modernidade e a actual constelação de práticas a que chamamos arte também pudessem identificar-se por princípios unitários, amplamente partilhados, recorrentes e relativamente estáveis. Coloca a questão num nível mais profundo e correcto: o de uma discussão coerente sobre o conceito de arte de nosso tempo. E sobretudo evidencia uma situação em que a prática artística não se esgota, não se limita aos objectos artísticos. Em que se enfatiza o carácter processual, criativo e experiencial da arte, e se resiste a uma visão imanentista do objecto artístico como uma entidade formal, autônoma e autoritária. Na criação, os procedimentos (mentais e técnico-formais) de que os produtos são o traço, o rasto, assumem um papel pelo menos tão importante quanto estes. Quando produz, o artista não só produz um objecto material, mas também uma concepção de que a obra vai ser o veículo e a confirmação. $\mathrm{Na}$ recepção esses resultados não são também todos autocontidos, determinados e finais; antes situações, cheias de potencialidades evocativas e sugestivas.

Parecem-me aspectos fundamentais a ter em consideração quando se pensa a educação artística hoje. Ajudam ainda a distinguir o ensinável do que não é. A posição central do novo, da capacidade de uma manifestação artística poder ser para nós instauradora de sentido, de poder alargar a nossa relação com o mundo, como critério de valorização da prática artística, implica que a criação artística é ela própria impelida por um componente irredutível de desconhecimento. Que não se confunde com espontaneidade, pureza ou inspiração. Pois bem, não me parece que se possa ensinar a consciência intensa desse desconhecimento. Os pontos de vista dos professores (e é irrelevante se são grandes artistas ou artistas menos grandes) não a substituem, evidentemente. Além deste, há outros elementos do processo criativo que não são ensináveis, e que seria interessante isolar cuidadosamente do que pode ser ensinado - a inventividade, a intuição, por exemplo.

Dentro do domínio do ensinável é possível, então, pensar, e decidir o que se deve ensinar. Nos dois casos que se consideraram, da educação artística na educação geral e como formação específica. (DIAS, 1994, pp.199-200)

\section{Qual a contribuição do setor educativo de um museu de arte neste processo? Pensamos}

que seja o de investir na possibilidade de fruição estética. Favorecer a compreensão da arte pelo contato com a produção dos artistas e também pela prática criativa em arte, permitindo experiências dos envolvidos, solução de problemas, exploração e experimentação na mesma linguagem que se apresenta nos objetos da cultura dos artistas. Uma visita ao museu com o educador sem a prática criativa pode ficar apenas na verbalização sobre o que ali se apresenta.

Para Dewey:

Art is a quality that permeates an experience; it is not, save by a figure of speech, the experience itself. Esthetic experience is always more than esthetic. In it a body of matters and meanings, not in themselves esthetic, become esthetic as they enter into an ordered rhythmic movement toward consummation. The material itself is widely human. (...) The material of esthetic experience in being human - human in connection with the nature of which it is a part - is social. Esthetic experience is a manifestation, a record and celebration of the life of a civilization, a means of promoting its development, and is also the ultimate judgment upon the quality of a civilization. For while it is produced and is enjoyed by individuals, those individuals are what they are in the content of their experience because of the cultures in which they participate. (DEWEY, 2005, p.339) 
Certamente o diálogo e o trânsito entre linguagens promovem conhecimento, mas possuem limites - busca-se traduzir em linguagem oral algo que se constitui de outro modo. A aproximação com a produção de um outro, o artista, colocando o visitante como alguém que faz "sua arte" no museu, considerando o repertório e as necessidades de quem se predispõem a esta situação, favorece a compreensão da outra linguagem de modo muito eficaz. Isto é o que se busca com as atividades do programa Interar-te: aproximar o participante do processo de criação dos artistas, como pessoas críticas e sensíveis, alguém que aprende não só pela razão mas que deixa aspectos internos, subjetivos, relacionados à percepção da relação consigo mesmo e com mundo serem exercitados nestas atividades. A produção contemporânea favorece este tipo de trabalho educativo, pois o contexto do artista ou especificamente da obra muitas vezes é semelhante ou próximo dos sujeitos "não artistas".

\begin{abstract}
A educação artística deve, para além do treinamento técnico, que também deve ser o mais amplo possível, e do ensinar a apreciar, exactamente habilitar os estudantes a abranger o mundo presente, e a desenvolver uma relação singular consigo próprios, e com seu ambiente, natural, social e cultural. Seja ela apropriativa, citacional, irônica, crítica ou paródica. É necessário habilitá-los com a capacidade de discernirem possibilidades fecundas e eficazes de actos criativos. E para isso é indispensável introduzi-los aos discursos sobre os vários aspectos do mundo contemporâneo. Sobre o lugar da criação artística e do indivíduo neste mundo. São discursos que se prolongam em palavras e materiais, que transitam, para trás e para diante, de artista a artista, de obra a obra, de tendência a tendência. Por isso a sua introdução deve ser feita a partir de obras artísticas. Até porque, para as compreender e apreciar, acabamos sempre por ter de tocar em assuntos que estão além dos ensinados numa formação clássica - sociológicos, históricos, políticos, científicos, econômicos, psicológicos, antropológicos. Se não o fizermos, a história da arte contemporânea não será mais do que um desfile gratuito de modas. (DIAS, 1994, pp.200-201)
\end{abstract}

Num museu de arte moderna e contemporânea muitas vezes trabalha-se a partir de resíduos de ações e produções de artistas, com imagens que não são a obra, mas registros de ações. O alargamento de significados a partir do que se vê, em discussão com o público não especializado, com posterior proposição para que ele possa se colocar no lugar do artista numa proposta desafiadora, reverberará em sua vivência de arte e museu (instituição) e constituirá uma experiência que ecoará por muito tempo, em detrimento de uma abordagem mecânica em que a obra lhe é explicada mas o sujeito não se reconheça nela, mesmo que contemple alguma proposta de atividade e esta não seja desafiadora. As sessões do programa Interar-te, em andamento até o presente momento, são justamente desafiadoras.

Diante do objetivo de investigação desta pesquisa, que é procurar a motivação dos pais a favorecerem a seus filhos crianças e adolescentes o conhecimento sobre arte, perguntamonos por que favorecer o ensino de arte em um museu? E mais, tratando-se do Museu de Arte 
Contemporânea da USP, cujo acervo é moderno e contemporâneo ${ }^{8}$, devemos nos perguntar o porquê de aproximar o público infanto-juvenil da produção artística moderna e contemporânea. Qual a importância em se discutir a arte contemporânea? É importante o distanciamento para se pensar o presente, num viés hegeliano, condição na qual podemos nos aproximar da arte moderna em detrimento da contemporânea? ${ }^{9}$

No Interar-te optou-se por tomar outro caminho. Acredita-se que ensinar arte pode favorecer o alargamento de experiências estéticas: a compreensão dos códigos do mundo da arte podem facilitar a fruição da natureza, do cotidiano, das construções humanas, assim como da própria arte, e também reverberar na política, no comportamento, nos modismos, no consumo.

Kant, em Resposta à pergunta: Que é 'esclarecimento'?, nos diz

Esclarecimento [“Aufklärung”] é a saída do homem de sua menoridade, da qual ele próprio é culpado. A menoridade é a incapacidade de fazer uso de seu entendimento sem a direção de outro indivíduo. O homem é o seu próprio culpado dessa menoridade se a causa dela não se encontra na falta de entendimento, mas na falta de decisão e coragem de servir-se de si mesmo sem a direção de outrem. (...) É tão cômodo ser menor. Se tenho um livro que faz as vezes de meu entendimento, um diretor espiritual que por mim tem consciência, um médico que por mim decide a respeito de minha dieta, etc., então não preciso esforçar-me eu mesmo. Não tenho necessidade de pensar, quando posso simplesmente pagar; outros se encarregarão em meu lugar de meus negócios desagradáveis. (KANT, 1974, pp.101-102)

Kant, neste texto, delega ao indivíduo a responsabilidade por sua capacidade de mobilização. Sem adentrar na complexidade de relações culturais e sociais da época de que nos fala (seu texto data de 1763), consideramos a mobilização interna, própria do indivíduo, numa perspectiva piagetiana, porém compartilhamos da compreensão de que a mobilização subjetiva é influenciada pelos aspectos da cultura e das experiências sociais, numa abordagem vigotskiana. Olhares culturais e experiências de vida são diretrizes da mobilização interna, individual. As experiências são relações com diversos grupos, em diversos momentos da vida. Esta pesquisa busca as relações entre aspectos favorecidos no âmbito das famílias e da educação não-formal (proveniente de ações da área educativa em museu de arte). Ou seja, as relações que favorecem a educação compreendida pela qualidade das relações significativas entre os sujeitos. É nesse campo de inter-relações e intersecções que se dá o processo pelo

\footnotetext{
${ }^{8}$ A obra mais antiga do MAC USP é uma pintura do artista Giacomo Balla de 1906.

${ }^{9}$ Há autores que datam o início da arte contemporânea na década de 1960, com a Arte Pop e Arte Minimal; outros apontam os anos 1980 como o marco histórico. Independente de datações, o que importa é que se trata da produção artística mais recente, no qual, compartilhe o público ou não disto, os aspectos de contemporaneidade, podem lhe ser apresentados e favorecidos pelas discussões e vivências elaboradas pelos educadores do Museu tendo como motivo a produção artística contemplada nas exposições do MAC USP.
} 
qual o sujeito adquire um referencial ao qual pode recorrer ao fazer suas escolhas - processo do qual a educação faz parte.

Pode a arte ensinar a pensar? A educação - trata-se aqui do ensino e aprendizagem de arte - pode. Para tanto a educação deverá ser não condicionadora ou meramente informativa, que exige respostas imediatas e mecânicas e a subserviência aos padrões pré-estabelecidos, à manutenção dos sistemas de dominação (econômicos, sociais, culturais). Considerando a educação de forma emancipatória, a arte pode levar à leitura do mundo de modo não acomodado e passivo: seja pela compreensão dos códigos dos meios de comunicação de massa, dos hábitos de um grupo ou da qualidade das relações sociais.

Este olhar sobre o papel do ensino de arte denuncia apenas seu aspecto pragmático, porém o ensino de arte possui também um caráter poético - afinal, por que o ser humano recorreu a esta forma de compreender, sentir, comunicar e expressar não vinculada a necessidades utilitárias? Dias (1994, p.196) discute os modos como o ser humano se relaciona com o mundo e produz cultura e afirma: racionalidade e fantasia coexistem.

O que importa aqui é constatar a importância da poesia (o simbólico) nas relações humanas - interpessoais, intrapessoais, com o meio natural, com o ambiente cultural - e, nesse âmbito, a arte é uma de suas manifestações necessárias. O homem não é só matéria, não se relaciona com o mundo apenas por este viés, por suas necessidades de sobrevivência, fisiológicas ou de aquisição de bens produzidos pela cultura; tão pouco apenas a lógica e a razão norteiam seu comportamento e seu modo de compreensão do mundo.

A reflexão de Kant sobre o esclarecimento citada acima (p.27), aponta, com todas as ressalvas, também o aspecto da atualidade: "não tenho necessidade de pensar, quando posso simplesmente pagar". Adaptando a questão para os sujeitos desta pesquisa, teríamos: "por que estar com os filhos durante a atividade no museu se eles estarão da mesma forma com os monitores e eu posso ficar sossegado e, depois, ir buscá-los?”. Esse seria um slogan para as áreas de lazer de shopping centers. Foi uma experiência da educadora criadora do Interar-te e proponente desta pesquisa, num contexto próximo ao citado, que motivou a estrutura e o objetivo maior desse programa - algo que, de tão simples e que deveria ser cotidiano, tornouse distante e esquecido: conviver, estar junto, trocar com os familiares.

A fruição estética é compreendida aqui como o ápice do contato com a obra de arte; momento em que, independentemente do grau de conhecimento sobre ela, porém sem desconsiderá-lo, há a identificação de elementos reconhecíveis pelo sujeito. Não se trata aqui do trabalho de especialistas, que cada vez mais redescobrem o objeto sobre o qual se 
debruçam durante $\operatorname{anos}^{10}$, mas da vivência do visitante leigo, mesmo aquele com hábito de frequentação de exposições de arte, que aprecia ir a museus, porém de modo algum se considera especialista. E, mais, considera-se a fruição estética como a capacidade de percepção e valorização de sutilezas ocasionais do cotidiano. Adquirir esta capacidade seria um potente aspecto do ensino de arte utilizado como metáfora para a melhoria da qualidade de vida, educando o ser humano a usufruir do que lhe é inerente e essencial: a necessidade de relações simbólicas.

Para “desler”, como diz o poeta Mário Quintana na epígrafe deste tópico, é preciso, primeiro, aprender a ler. Para desconstruir, para ler as brechas, perceber as metáforas, precisase, primeiro, reconhecê-las, identificá-las, localizá-las. E é nesse sentido que a educação em museu de arte pode contribuir, sempre como parceira das outras instâncias educativas: educação formal, não-formal, a que se passa nas famílias (nosso objeto de pesquisa) e, ainda, na educação em arte. Ela pode ensinar a ler e a almejar, por estratégias e abordagens abertas, reflexivas, o "desler”. Nesse sentido, pode contribuir à fruição estética mas não realizá-la, pois cabe ao sujeito a autoria deste processo.

\subsection{Educação no Museu de Arte Contemporânea da Universidade de São Paulo}

O MAC USP, desde suas primeiras gestões de diretoria, contou com ações educativas. Apresentamos a seguir algumas delas.

O Museu de Arte Contemporânea da Universidade de São Paulo, criado em 8 de abril de 1963, é um museu universitário e público. Seu primeiro diretor, o Prof. Dr. Walter Zanini, foi seu gestor da inauguração até março de 1978. A gestão de Zanini deu abertura a jovens artistas para produzir e expor seus trabalhos no Museu; realizou duas exposições do Jovem Desenho Nacional (a primeira em 1963), duas da Jovem Gravura Nacional (a primeira em 1964) e oito edições da Jovem Arte Contemporânea (entre 1967 e 1974). Como diretor, ele fez do Museu não só um espaço para a produção mas, também, de debate e discussão democráticos sobre arte contemporânea, lembrando que o MAC foi criado num momento político delicado para esse tipo de atitude: um ano antes do golpe militar de 1964.

\footnotetext{
${ }^{10}$ Pesquisa de Abigail Housen nos Estados Unidos na década de 80, conhecida como "Níveis de Apreciação Estética", aponta indícios nesse sentido.
} 
O MAC USP, na gestão do Prof. Zanini, ainda não contava com equipe técnica especializada em educação ${ }^{11}$, mas já podemos destacar ações que poderiam ter surgido por demanda de uma área de educação do Museu. Ou seja, o MAC USP iniciou suas atividades com uma política que valorizava ações educativas. Podemos, aliás, inferir que dessa natureza política da instituição criou-se condições para a implantação desse setor.

A primeira exposição de cunho didático do MAC foi realizada em 1963, intitulada 14 Reproduções de Obras de Pintores Americanos, organizada pelo MAC USP e apresentada na FAU USP e no Centro de Ciências, Letras e Artes de Campinas. Também exposições de trabalhos infantis foram realizadas, sendo de 1966 a 85 Colagens Infanto-juvenis, de 1970 a Arte Infantil nos Museus dos Estados Unidos", de 1971 a Homenagem a Franz Cizek ${ }^{12}$ e de 1972 a A Expressão Plástica da Criança Excepcional. Para esta última foi organizado, em palavras do próprio professor Zanini (1972), “um projeto educacional/cultural com painéis de debates e um catálogo com textos sobre o menor deficiente mental com artigos que tratam das questões por vários ângulos".

Em 1973, entre 22 de maio e 13 de junho, foi oferecido o curso de "divulgação e extensão cultural" Arte-educação no $M A C^{13}$ ministrado pela Prof ${ }^{\mathrm{a}}$. Ana Mae Barbosa, que mais tarde viria a ser diretora do MAC.

A segunda gestão de direção do Museu, do Prof. Dr. Wolfgang Adolf Arthur Pfeiffer, inaugurou as gestões de quatro anos de duração: teve início em 1978 e foi até 1982. Nesse período ocorreu a I Mostra de Artes Plásticas Infanto-juvenil Metropolitana.

Durante a gestão de direção da Prof ${ }^{\mathrm{a}}$. Dra ${ }^{\mathrm{a}}$. Aracy Abreu Amaral ${ }^{14}$, de 1982 a 1986, a criação de um departamento de educação no MAC esteve em discussão. Em janeiro de 1985 foi criado o Setor de Arte-Educação, vinculado à Divisão de Difusão Cultural. Anos antes, num documento de 1983 intitulado "Cronograma de implantação", consta o planejamento para criação de um "Departamento de Educação do Museu de Arte Contemporânea da USP"15 que, embora vislumbrasse privilegiar a comunidade uspiana (alunos, professores e funcionários) em suas atividades, também previa atender a comunidade externa. Foram esboçados neste documento muitas áreas de atuação para diferentes perfis de público, que

\footnotetext{
11 O Museu contava, em 1966, com apenas quatro funcionários regulares: o diretor, dois serventes e um motorista. O quadro aumentou em 1967 com a contratação de colaboradores para serviços técnicoadministrativos. (Walter Zanini. Texto de 17 de janeiro de 1968. (Arquivo do MAC USP - Fundo MAC USP 00049/001 V.1).

${ }^{12}$ Educador que criou, em 1897 em Viena (Áustria), a Escola de Arte Infantil ou Escola de Arte e Ofícios.

${ }^{13}$ Boletim Informativo no ${ }^{\circ} 196$, de 12/05/1973. (Arquivo do MAC USP - Fundo MAC USP 0030/14).

${ }^{14}$ A gestão da Prof ${ }^{\mathrm{a}}$. Aracy Amaral foi marcada por uma reestruturação do Museu para adequação ao Regimento Geral de Museus da USP, de 1982. Foram criadas as divisões Administrativa, Científica e de Difusão Cultural.

${ }^{15}$ Proposta de Cronograma de Implantação do Departamento de Educação do MAC USP de 09 de maio de 1983 de Elvira Vernaschi. (Arquivo do MAC USP - Fundo MAC USP DE 0001/001).
} 
vieram a ser realizadas pelo Setor anos depois, tais como monitoria, conferências, audiovisuais, exposições didáticas, ciclo de estudos para professores, laboratório de redação, laboratório prático, representação teatral, aula prática sobre o acervo (um ator representando o artista no ato da feitura da obra) e exposições temporárias (debates com os próprios artistas sobre sua obra e projeção de audiovisual sobre a exposição).

Em 1983, no Boletim Informativo de junho das atividades do Museu ${ }^{16}$, há a divulgação de um serviço de visitas guiadas para escolas e público em geral, com organização da Prof ${ }^{a}$. Elvira Vernaschi, que em 1984 seria incumbida da coordenação do Centro de ArteEducação. Nesse ano a Prof ${ }^{\text {a }}$. Elvira estabeleceu contatos com a Secretaria de Educação para receber no Museu público externo à Universidade, tendo realizado um mapeamento de escolas próximas ao Parque Ibirapuera e à Cidade Universitária, com visitas guiadas para professores e alunos do ensino básico, estudantes de pós-graduação e professores do Centro Cultural São Paulo. O Departamento de Educação foi planejado com base em pesquisas e visitas técnicas a outras instituições e implantado para atender diferentes perfis de público, contemplando um leque de ações inclusivas e diversificadas.

As atividades educativas junto ao Setor de Arte-Educação se iniciaram em janeiro de 1985 , com atuação de Martin Grossmann e Mônica Nador. Ambos, juntamente com Luciana Brito, haviam proposto à Prof ${ }^{\text {a }}$. Aracy Amaral, em 1983, o projeto de monitoria-ateliê elaborado como trabalho de conclusão do grupo das disciplinas pedagógicas da Licenciatura Plena em Educação Artística da Fundação Armando Álvares Penteado (FAAP) que, como comenta Grossmann em sua dissertação de mestrado (1988, p.51), “de simples trabalho avaliativo em grupo, este projeto aprofundou-se de tal modo, que acabou por se transformar em uma proposta a nível profissional”. A implantação do projeto tornou-se possível com a contratação de Grossmann pelo MAC USP em 1985.

Esta proposta estava em consonância com discussões que seriam tratadas com afinco ainda na mesma década, pela Prof ${ }^{\mathrm{a}}$. Ana Mae Barbosa, que é o ensino de arte nas escolas e a inserção da História da Arte no currículo escolar. (GROSSMANN, 1988, pp.51-52) A proposta do trio Brito, Grossmann e Nador era relevante, também, sob o aspecto de sua implantação no Setor de Arte-Educação do MAC, com uma estratégia de trazer a experiência em ateliê somada à abordagem das obras. Destacamos por tangenciarem aspectos estruturais do atual programa Interar-te:

Gerado com a intenção de proporcionar uma maior interação entre a comunidade e o museu, este projeto estruturou-se em uma concepção de monitoria mais dinâmica e

\footnotetext{
${ }^{16}$ Boletim Informativo $\mathrm{n}^{\mathrm{o}}$ 455, de junho de 1983. (Arquivo do MAC USP - Fundo MAC USP PUB/BI/0021).
} 
participativa: não apenas uma visita rápida e efêmera pelo espaço expositivo, mas uma experiência além de inquietante, prazerosa, que provocasse e estimulasse um estar crítico e sensível do visitante, uma experiência passível de aquisição de conhecimento. Para tanto, subdividiu-se a permanência do grupo no museu em dois momentos interdependentes: a) a visita em si pelo espaço expositivo: a condução pelo espaço do museu, sob a coordenação do monitor (por ser ele conhecedor íntimo deste espaço) segue certos roteiros, ou melhor, traçados transformados pela interação entre grupo e monitor nos diversos momentos desta convivência. b) atividade prático-plástica no atelier: complemento à visita, esta fase visa proporcionar a cada participante um momento prazeroso através do fazer expressivo individual ou em grupo (dependendo das propostas ou do andamento da visita) onde não se espera a priori resultados concretos (trabalhos acabados ou mesmo relacionados com a visita). A intenção implícita é facilitar acesso à consciência da expressão pessoal e reforçar/ampliar a vivência no espaço expositivo.

Julga-se que a somatória/interação entre estas duas etapas no museu possa produzir efeitos qualitativos no visitante/estudante facilitando assim uma digestão $a$ posteriori das poucas horas de permanência no museu. (GROSSMANN, 1988, pp.52-53)

Em abril do mesmo ano Grossmann e Nador elaboraram ações para uma exposição dirigida ao público deficiente sensorial visual intitulada Espacialidade e Materiais na Escultura Contemporânea (27 de agosto a 13 de outubro). Conforme um relatório de visitas ${ }^{17}$ deste público, elaborados por ambos, nas "visitas dirigidas" à exposição era permitido o toque nas obras. Em um registro descritivo e reflexivo acerca desses atendimentos, Nador conclui:

Foi interessante a mostra como estímulo a esse público (e a nós mesmos, por que não?) perceberem as possibilidades de ampliação do seu repertório vivencial que um museu como esse pode oferecer, independente das etiquetas nas esculturas em Braille. Aliás, o interessante seria que essas etiquetas fossem uma regra no Museu. Agora que já aprendemos que cegos também gostam de arte, acho que outras exposições como essa teriam uma conotação discriminatória e paternalista questionáveis. Tanto nós quanto eles devemos entender que o Museu está aberto para todos que o quiserem. ${ }^{18}$

Somam-se a estas, outras ações do Setor, como encontros com artistas; o curso $O$ Museu como Escola ${ }^{19}$ de aperfeiçoamento para professores, em que além de visitas às exposições havia aulas práticas em ateliê, palestras e aulas sobre História da Arte ministradas por docentes convidados; a publicação do catálogo $O$ que é o $M A C$, em "linguagem simples para crianças e para público leigo"; e a organização da Semana de Arte-Educação e o Museu para professores da rede estadual de ensino "mantido por um convênio entre a Secretaria Estadual de Educação e a USP" 20 que contou com apresentações dos setores educativos de outras instituições da cidade (Pinacoteca, Museu Lasar Segall, Museu de Arqueologia da

\footnotetext{
${ }^{17}$ Relatório de visitas dos deficientes visuais, 04 de novembro de 1985, assinado por Martin Grossmann. (Arquivo do MAC USP - Fundo MAC USP DE 001/001).

${ }^{18}$ Relatório de visitas dos deficientes visuais, 29 de outubro de 1985, assinado por Mônica Nador. (Arquivo do MAC USP - Fundo MAC USP DE 001/001).

${ }^{19}$ Relatório das atividades do Setor de Arte-Educação do MAC USP, 24 de fevereiro de 1986. (Arquivo do MAC USP - Fundo MAC USP DE 0023/001).

${ }^{20}$ Boletim Informativo $\mathrm{n}^{\mathrm{o}}$ 516, de junho de 1986. (Arquivo do MAC USP - Fundo MAC USP PUB/BI/0024).
} 
USP, Museu de Pré-História da USP, Centro Cultural São Paulo e Museu de Arte de São Paulo), além de atividades programadas em conjunto com o curso de atualização organizado pela Prof ${ }^{\mathrm{a}}$. Ana Mae Barbosa da Escola de Comunicação e Artes da USP. Para as exposições, preparava-se "pasta com material didático (questionário, jogos, etc.) para enriquecer a visita monitorada das crianças e adolescentes" 21 .

Na gestão seguinte, da própria Prof ${ }^{\mathrm{a}}$. Dr ${ }^{\mathrm{a}}$. Ana Mae Tavares Bastos Barbosa (19861993), intensificou-se as ações do Setor de Arte Educação no Museu. Em 1991 o Setor passa a ter o estatuto de Divisão de Educação.

Uma das diretrizes assumidas pela Direção do MAC, manifesta logo nas primeiras promoções desta gestão, trata de ir ao encontro de um público mais amplo, diversificando suas atividades, no esforço de diminuir a distância entre a produção artística erudita e um público de extração sócio-cultural mais carente. As exposições "Arte e Loucura" e "Carnavalescos", com as palestras, mesas redondas e vídeos que as acompanhavam, exemplificam essa diretriz, abrigando e divulgando a produção artística de grupos sociais geralmente alijados do circuito de galerias, centros culturais e museus de arte. ${ }^{22}$

Em 1986, em conjunto com a Prof ${ }^{\mathrm{a}}$. Elza Ajzenberg, Barbosa organizou o primeiro curso de especialização Arte-Educação em Museu. (BARBOSA, 2005, p.84) Em sua gestão, promoveu simpósios internacionais intitulados de Ensino de Arte e sua História e outros cursos com educadores estrangeiros. O compromisso da Prof ${ }^{\mathrm{a}}$. Ana Mae Barbosa com a educação no Museu pôde ser atestado desde sua Oração de posse na diretoria do MAC USP. ${ }^{23}$

\begin{abstract}
(...)
Um dos fatores responsáveis pelo aumento de público para a arte moderna e/ou contemporânea foi a mudança do conceito de museu.

Museu não é mais visto apenas como o lugar da guarda cuidadosa da obra de arte. É isto mas na mesma medida é um lugar de aprendizagem, de educação informal de alto desenvolvimento para os indivíduos, e de impregnação estética provocada.

Além de preservar a obra de arte o museu é responsável em relação ao seu público pelo desenvolvimento de modos de apreciação artística, e pela decodificação da imagem estética levando ao desenvolvimento do processo criador e da educação emocional daqueles que o freqüentam.

Por outro lado a função da arte também mudou.

Os cognitivistas nos demonstraram a importância da arte para o aprimoramento do conhecimento sensual, sensorial e presentacional do mundo que é igualmente importante mas termologicamente diferente do conhecimento científico.

(...)

Para tudo isto o MAC está aí, Magnífico Reitor. Gostaria que fosse usado pela USP da mesma maneira que as Universidades de Yale e Harvard usam os seus museus (e o nosso acervo é tão importante quanto o deles) isto é para servir de instrumento de inter-relação entre a Universidade e o público que está do lado de fora dela.
\end{abstract}

\footnotetext{
${ }^{21}$ Relatório de Atividades do Setor de Arte-Educação de 1985, 1986 e 1987, s/d. (Arquivo do MAC USP Fundo MAC USP DE 001/002).

${ }^{22}$ Introdução do Relatório Anual de Atividades do MAC USP de 1987. (Arquivo do MAC USP - Fundo MAC USP DR0061/002 V.1).

${ }^{23}$ Ana Mae Tavares Bastos Barbosa: Oração de posse na diretoria do Museu de Arte Contemporânea da Universidade de São Paulo, dezembro 1986. (Arquivo do MAC USP - Fundo MAC USP DR 0049/001 V2).
} 
Na gestão da Prof ${ }^{\text {a }}$. Ana Mae Barbosa foram criados: um ateliê permanente de gravura, sob orientação do professor e artista Evandro Carlos Jardim; a Revista do MAC, que incluía artigos sobre o ensino de arte; o Projeto Olharte, coordenado pela educadora Renata Sant'Anna, que funcionou de 1991 até 1997 com exposições e quatro publicações para crianças sobre artistas cujos volumes Maria Martins, com texto da Prof ${ }^{\mathrm{a}}$. Katia Canton e projeto gráfico de Maria Tereza Louro e Goeldi, de Alberto Martins e Luise Weiss, receberam o Prêmio Jabuti de melhor livro infantil e juvenil, respectivamente em 1997 e 1996; o programa Lazer com Arte para a Terceira Idade, coordenado pelo educador Sylvio Coutinho desde 1989 até hoje, cujos cursos culminam em exposições de extroversão da produção dos participantes; projetos de exposições e atendimento com recursos materiais específicos para públicos com necessidades educativas especiais como o Museu e a Pessoa Deficiente, denominado a partir de 1998 como Museu e Público Especial (TOJAL, 1999), coordenado de 1991 a 2002 pela educadora Amanda Tojal; e o programa Museu, Educação e o Lúdico, para crianças de Educação Infantil, criado em 1995 pela educadora Maria Angela Serri Francoio.

Em 1993, as docentes Prof $^{\text {a }}$. Carmen Aranha e Prof ${ }^{\text {a }}$. Katia Canton passam a integrar a equipe da área de Educação. Ambas desenvolvem pesquisas que geram publicações tanto para o público universitário como à comunidade externa à USP: materiais educativos, exposições e ações educativas para o Museu.

Consideramos importante visualizar, numa instituição pública, este processo de implantação do departamento de educação, de seu projeto às ações efetivas, no decorrer de décadas, mas não é objeto desta pesquisa um histórico completo da Divisão TécnicoCientífica de Educação e Arte do MAC USP. As ações da Divisão continuaram a ser desenvolvidas nas gestões seguintes dentro do perfil de atuação traçado; além das ações citadas anteriormente, que adentraram gestões seguintes, houve a criação de novos programas e projetos educativos. Em 1998 a Divisão de Educação passou a ser denominada de Divisão Técnico-Científica de Educação e Arte, a partir de Regimento Interno de final de 1997.

A segunda gestão da Prof ${ }^{\text {a }}$. Lisbeth Rebollo Gonçalves (2006-2010) foi de apoio à atuação de educadores da Divisão Técnico-Científica de Educação e Arte e de retomada de atividades na sede do Parque Ibirapuera ${ }^{24}$. Nesse momento solicitou-se projetos de atividades para crianças nessa sede e a contra-proposta de uma ação para famílias foi aceita, tendo sido criado o programa Interar-te.

\footnotetext{
${ }^{24}$ Entre meados de 2000 e agosto de 2003 o MAC USP não realizou exposições na sede Ibirapuera, período em que o espaço passou por reformas e foi cedido para a realização de eventos artísticos de outras instituições, como a Mostra do Redescobrimento.
} 
Em entrevista exclusiva para esta pesquisa (Apêndice 4), a Prof ${ }^{\text {a }}$. Lisbeth Rebollo fala de sua experiência e concepção do lugar da educação no Museu. Sobre ações educativas para as famílias, afirmou que,

(...) na linha do que disse antes, talvez esse tipo de atividade pudesse ser algo fundamental para a formação do futuro cidadão. Em vez de ir ao museu sozinho ou com o grupo de sua escola, ir com a sua família criaria um sentido diferente para esta vivência. Começaríamos a construir uma experiência de sentido como a que se encontra, por exemplo, na França, quando as famílias, levando seus filhos nos carrinhos, ainda sentadinhos nos carrinhos, visitam o museu e compartilham de modo mais afetivo a experiência de aproximação à arte. Começaríamos a colaborar para acontecer a troca de valores sociais fundamentais no momento da socialização primária, que dá as bases para o futuro cidadão. $\mathrm{Na}$ educação familiar estão os pilares de socialização que serão complementados depois pela escola. É claro que, paralelamente, da escola mais elementar até a universidade, no convívio dos museus, vai se construindo o gosto pela arte, o hábito de frequentar estas instituições, e acontecerá a sensibilização, fundamental na formação das pessoas.

Observando as ações educativas do MAC, desde seu início, que incluem ações destinadas ao público infantil e portador de necessidades educativas especiais, entre outros, antes mesmo da criação de um departamento específico para isso, com profissionais especialistas, podemos inferir que da prática chegou-se à demanda, ou, de direcionamentos inclusivos e democráticos chegou-se ao momento institucional propício para a criação de um setor educativo. Está gravada na política institucional desse Museu sua função social - a de formar público que frui de arte, preocupando-se com o início desse processo, da educação formal básica e a educação informal até o público universitário, que poderíamos considerar outra ponta desse processo.

As ações educativas da instituição citadas acima foram mencionadas relacionando-as apenas às gestões de diretoria por considerarmos que estas ocorrências são relevantes no âmbito da política institucional mesmo antes da criação de uma área específica sobre educação sob a responsabilidade de funcionários especialistas. No MAC, as decisões institucionais são tomadas por um conselho consultivo do qual o diretor é um dos membros e seu presidente. As propostas da equipe de educadores são discutidas com a chefia imediata e os demais membros da equipe antes de serem encaminhadas ao conselho para aprovação.

O MAC é uma instituição comprometida com as premissas de ensino, pesquisa e extensão da Universidade. Sob essa premissa, ao promove pesquisa sobre seu acervo com o trabalho dos docentes, oferece aulas de Graduação e curso de Pós-graduação. Com a atuação da Divisão Técnico-Científica de Educação e Arte aproxima-se da comunidade externa.

Um último aspecto do educativo do MAC a ser ressaltado é o fato de que, sendo um museu universitário, pode contar com o apoio de programas de bolsa para acolher estagiários, tanto alunos da própria Universidade como de outras instituições de ensino superior. Bolsistas 
e estagiários que atuaram no programa Interar-te no período estudado sob supervisão da pesquisadora participaram de entrevista por grupo focal. Seus depoimentos indicam que, com a experiência no Museu, obtiveram formação significativa em educação e em arte contemporânea, evidenciando, assim, a contribuição do Interar-te com a formação acadêmica dos graduandos.

No depoimento abaixo (Apêndice 3.4), uma aluna de Artes Visuais, aponta a relevância do estágio no MAC USP para sua formação, tanto sobre arte contemporânea quanto sobre mediação em museu de arte:

\begin{abstract}
Para mim, primeiro foi o contato com arte contemporânea, porque até o momento em que comecei a fazer estágio lá, muito pouco a academia falava de arte contemporânea, ou nem falava de arte contemporânea. Então, foi o primeiro lugar que eu tive contato com arte contemporânea e pensar arte contemporânea, porque, a partir do momento que você vai ser um mediador, você já vai discutir e já vai buscar referências, pra você poder mediar. Então, é... Mais do que aprender sobre a questão educativa, pra mim foi aprender sobre arte contemporânea e sobre o Interar-te é... Porque tinha uma questão das relações, tinha a questão familiar, mas acima de tudo tinha um processo pra chegar até ali, assim...

E isso me marcou muito, em muitos aspectos, assim... Vontade de, depois, de começar eu mesma a produzir, vontade de trabalhar com arte-educação, porque até então eu não sabia que, que... $\mathrm{O}$ que era ser um arte-educador. Foi meio que junto com as disciplinas, e tal, mas eu comecei acho que antes no MAC, até, que as aulas foram... Foram aperfeiçoando isso. E acho que uma outra coisa que me marcou, é... Aquela leitura despretensiosa, assim... Então não era leitura de estudante de arte, não era leitura de adulto que acha que sabe, era criança e muitos pais que, às vezes, sei lá, no dia a dia, no cotidiano deles, não, não... Sei lá, estavam sempre naquela rotina, assim... Então, o Interar-te parecia que trazia eles pra uma outra realidade que eles não estavam acostumados, então, quantos pais pintados igual os filhos, sujos, iguais aos filhos. Então, essa relação colaborativa dos dois era muito marcante, assim, e... Porque a criança tem aquela coisa espontânea, fala coisas legais, tal, mas, assim, dos pais é... Com os filhos. Foi lá, também, que eu me liguei assim e que foi muito prazeroso.
\end{abstract}

\title{
2.4. O programa educativo Interar-te do MAC USP
}

O programa educativo Interar-te da Divisão Técnico-Científica de Educação e Arte do MAC USP foi criado para atender a uma demanda institucional da sede do Museu no Parque Ibirapuera: reativar as ações de educação por especialistas da área nessa sede. Ações desse tipo foram interrompidas durante a gestão de diretoria do Prof. Teixeira Coelho. Na gestão da Prof $^{\mathrm{a}}$. Elza Ajzenberg foram retomadas e na gestão da Prof ${ }^{\mathrm{a}}$. Lisbeth Rebollo foi solicitado à educadora lotada no Ibirapuera que organizasse uma programação infantil. Considerou-se que iniciar mais um programa educativo destinado ao público infanto-juvenil em uma cidade como São Paulo, onde há inúmeras atividades para este público, só representaria uma 
contribuição diferenciada se visasse a qualidade da educação da população, no âmbito das ações em educação não-formal.

$\mathrm{Na}$ cidade que educa todos os seus habitantes usufruem das mesmas oportunidades de formação, desenvolvimento pessoal e de entretenimento que ela oferece. $\mathrm{O}$ "Manifesto das Cidades Educadoras" aprovado em Barcelona em 1990 e revisto em Bolonha em 1994, afirma que "a satisfação das necessidades das crianças e dos jovens, no âmbito das competências do município, pressupõe uma oferta de espaços, equipamentos e serviços adequados ao desenvolvimento social, moral e cultural, a serem partilhados com outras gerações. (...) A cidade oferecerá aos pais uma formação que lhes permita ajudar os seus filhos a crescer e utilizar a cidade num espírito de respeito mútuo". (GADOTTI, 2006, pp.133-139).

Após um levantamento de atividades para diferentes perfis de público, considerando aspectos específicos dos frequentadores do Parque Ibirapuera, os programas foram aprovados pela chefia imediata, Prof ${ }^{\text {a }}$. Katia Canton, implantados paulatinamente - dentre eles o Interarte. Desde a concepção do programa, a própria procura de um nome que o representasse facilitou a compreensão dos objetivos que teria: aproximar da arte e integrar as famílias que buscam lazer aos finais de semana no Parque Ibirapuera e que poderiam vir a conhecer obras de arte no Museu de Arte Contemporânea da $\mathrm{USP}^{25}$ nesse passeio. E alguns desafios também foram delineados nesse processo: como integrar os componentes dos grupos compostos por adultos acompanhantes do público infanto-juvenil, representantes de diferentes gerações e com diversos vínculos afetivos e sociais? O público-alvo estabelecido para o programa Interar-te, diante desses desafios, foi adultos com crianças ou jovens em visita ao parque. $\mathrm{O}$ Museu considera este como público espontâneo. A definição de família para o programa é, portanto, adulto acompanhado de criança, não importando se o responsável é parente ou não vizinhos, amigos, pais de amigos também são acompanhantes bem-vindos.

Conceitos sobre família e lazer que auxiliam na compreensão do programa Interar-te serão abordados nos capítulos seguintes. Adiantamos que, embora o termo lazer seja, segundo Edmir Perrotti (PERROTTI, 1990, pp.94-95) ao interpretar palavras de Hannah Arendt, “(...) comportamento subordinado à esfera da produção, do econômico, uma vez que sua medida é dada pelo trabalho destinado à satisfação de necessidades vitais", busca-se através do Interarte, com a exigência da participação efetiva da família, a contribuição para a qualidade desse “tempo exíguo" em nossa sociedade. Puig e Trilla (2004) apontam caminhos nesse sentido: se estivéssemos buscando entreter os menores para os maiores se dedicarem a outros afazeres num fim de semana, estaríamos contribuindo para a manutenção do sistema da cultura

\footnotetext{
${ }^{25}$ O Museu de Arte Contemporânea da USP, desde sua inauguração, em 1963, possui uma sede no Parque Ibirapuera, no terceiro andar do Pavilhão Ciccillo Matarazzo. Possui, também, sedes na Cidade Universitária e está em vias de receber do Governo o Palácio da Agricultura.
} 
atrelada ao mercado. Porém, é na exigência e na manutenção de uma participação ativa de todos os envolvidos numa sessão do programa que se contribui para a qualidade da educação no Museu, considerando seu potencial como promotor de experiências significativas com a cultura e com a sociedade, através de atividades de ócio que popularmente vemos nomeadas como de entretenimento. A relação entre tempo dedicado ao trabalho e tempo livre e atividades de ócio serão discutidas em outro capítulo da pesquisa.

Durante as atividades do Interar-te os adultos participam de diferentes maneiras e quase sempre são pegos de surpresa quando iniciantes quando estão lá pela primeira vez. Um pai declarou, certa vez: "Eu não sabia que ia ter que fazer também, não tenho habilidades manuais... Mas foi importante ter vivenciado isso com minha filha" ${ }^{26}$. Essa frase apresenta uma visão preconcebida acerca das artes visuais: a necessidade de habilidades manuais para o desenvolvimento de qualquer atividade. Podemos atribuir essa opinião a modelos tradicionais de ensino, além de uma concepção própria de arte: obras boas são as bem feitas tecnicamente, trabalhosas. Considera-se técnica importante, senão a obra não se materializaria, mas o artista não precisa necessariamente dominá-la e sim conhecê-la a ponto de orientar e dialogar com técnicos, sejam estes auxiliares de ateliê, trabalhadores de indústrias, especialistas em informática, designers ou outros tantos que a construção de uma obra de arte contemporânea requeira.

No mais, uma atividade de duas horas ${ }^{27}$ que inclui o contato com uma obra de arte além da prática em ateliê não pode pretender aprofundar técnicas, exigindo esse domínio como pré-requisito do público. Vale retomar que os objetivos do Interar-te são: promover maior aproximação entre membros familiares e alargar seu conhecimento em artes visuais. Para tal, as estratégias privilegiam algumas vezes aspectos cognitivos, outras vezes técnicos ou, ainda, contextuais sobre a obra, o processo de criação do artista ou a história da arte.

As propostas de atividade do programa são muito variadas de sessão para outra. Os acompanhantes adultos interagem de maneiras diversas com os menores: ora são os seus auxiliares, ora realizam, lado a lado, suas próprias tarefas. Ao final, todos participam das discussões sobre os trabalhos e as reflexões realizadas sobre as obras em exposição, apresentando sua própria produção e o que os marcou no desenrolar das propostas. Com a produção de cada um do grupo sendo comentada, aprende-se com o colega: sua interpretação da proposta, seu olhar sobre o próprio trabalho e sobre o dos demais participantes e as relações com as obras visitadas na exposição. A aprendizagem decorrente dessa forma de abordagem, a

\footnotetext{
${ }^{26}$ As falas espontâneas dos participantes foram registrada no diário de campo da educadora.

${ }^{27} \mathrm{O}$ programa tem, atualmente, duas horas e meia de duração.
} 
partir da qual há leitura visual não só da produção de artistas mas das variadas formas de apresentação contemporânea de imagens da cultura visual, é apontada por Iavelberg (2006).

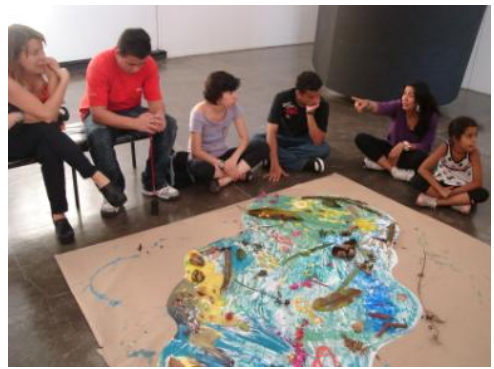

Figura 5 - Mãe (apontando) comenta os resultados do trabalho coletivo.

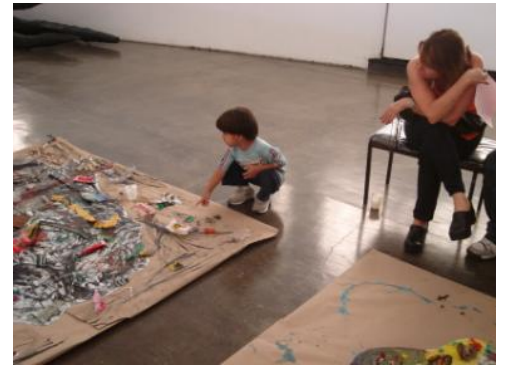

Figuras 6 e 7 - Menino de 4 anos comenta a produção, observado pela artista Renata Barros.

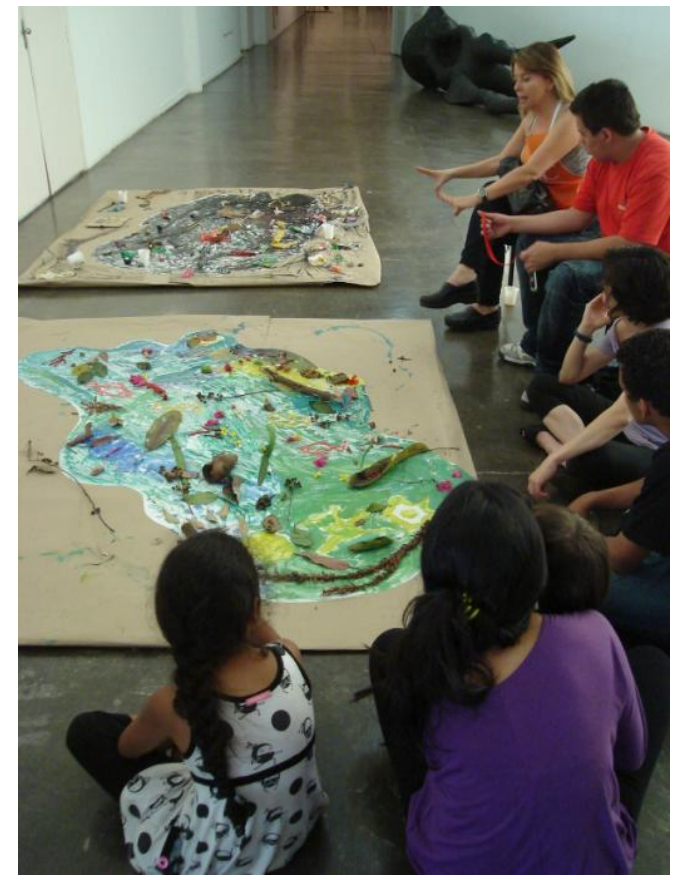

Figura 8 - A artista Renata Barros comenta os trabalhos realizados sob sua condução em oficina especial do Interar-te na exposição Poéticas da Natureza, em agosto de 2008.

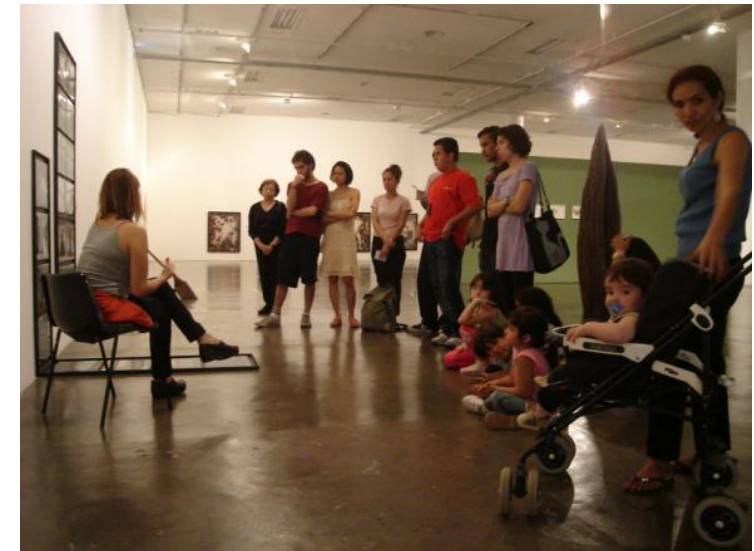

Figura 9 - A artista Renata Barros (à esquerda) apresenta sua obra integrante da exposição Poéticas da Natureza.

Quando há disponibilidade, artistas podem ser convidados a apresentarem sua obra em exposição e conduzirem uma oficina. Acima, à direita, a artista Renata Barros apresenta sua obra integrante da exposição Poéticas da Natureza.

São as exposições em cartaz na sede do MAC USP no Parque Ibirapuera que motivam as propostas de cada sessão do Interar-te. Pressupõe-se que o diferencial de um museu de arte sejam suas obras, portanto nada melhor do que elas para servir de ponto de partida para as oficinas que visam a integração familiar e a aproximação com as artes visuais. Esse vínculo com a obra de arte original é fundamental dentro das ações do Museu, uma vez que trata-se do gerenciador de um acervo público e entende-se como uma de suas obrigações a geração de diálogos sobre sua 
coleção e demais obras integrantes de exposições. No Interar-te, a partir desse contato, propõe-se atividades que aproximem o público dos procedimentos presentes no trabalho de arte do artista em questão e, assim, cumprir a função social de aproximar os membros familiares. Todas as oficinas são gratuitas, assim como o acesso às exposições do Museu.

Uma exposição de arte no MAC costuma durar alguns meses e pode gerar diferentes sessões do Interar-te. Uma das estratégias das oficinas é a visitação a um recorte (obras selecionadas) da exposição que servirá de tema para as atividades no ateliê. Considera-se importante a desaceleração numa visita a exposições, por isso a opção pelo contato com poucas, geralmente uma, obras. Essa postura reconhece e busca responder à análise de Jean Galard (citada anteriormente na página 20) sobre o comportamento do público em exposições, ficando poucos segundos diante de cada obra. Acredita-se que para chegar à fruição estética o visitante precisa aprender a conhecer o objeto, formulando perguntas que nem sempre são respondidas só pela observação e que demandam uma postura de desaceleração para acompanharem-no na busca do conhecimento significativo.

As etapas de um dia de atividades no Interar-te são: leitura de obras na exposição como dissemos, o contato com a obra de arte original é insubstituível e o grande diferencial do aprendizado de arte em um museu - e oficina. Nessa segunda etapa são propostas situações que contemplem o repertório de cada participante, levando-se em conta suas diferentes faixas etárias para facilitar a compreensão de questões relacionadas às obras vistas e discutidas na exposição. Deste modo, prática e reflexão podem se dar a partir ou não de atividades que geram "produtos". O resultado, individual ou em grupo, das oficinas pode também ser efêmero. E, ainda, dependendo da pertinência, a programação pode ser invertida, com a visita à exposição ocorrendo após a oficina no ateliê.

Até uma definição de duração, horário e dia para sua realização, as oficinas do Interarte passaram por um período de experimentações, entre os meses de outubro de 2006 e janeiro de 2007. Foi constatada maior frequência do público aos sábados à tarde e optou-se, então, pelo horário das 15 às 17 horas, com periodicidade mensal. As oficinas acontecem no segundo sábado de cada mês, salvo quando há a coincidência de algum feriado, a montagem de novas exposições no Museu ou a adequação à agenda de artistas convidados para ministrarem oficinas nos eventos chamados de "especiais". Também a sessão do mês de outubro, prefere-se realizá-la no próprio feriado que coincide com o Dia da Criança. Pretendese com essa regularidade a criação de uma identidade do programa e minimizar a competição com ações de mesma natureza de outros museus de arte na cidade de São Paulo. 
Um diferencial do Interar-te é contemplar pessoas de faixas etárias tão diferentes. No período estudado houve a participação de crianças e jovens de 4 a 18 anos, acompanhados por pais, irmãos, vizinhos, tios, avós, amigos, padrastos e madrastas. A idade mínima recomendada é 5 anos, mas menores acompanhantes de grupos familiares são bem recebidos: quando a proposta pode ser desenvolvida por eles, são inseridos ao grupo; quando não, são disponibilizados materiais de desenho e pintura para que realizem atividades livres e de exploração de materiais artísticos.

Parte do público do Interar-te no período pesquisado foi de famílias de funcionários e prestadores de serviços do Museu: dois educadores, uma analista acadêmica, uma curadora, um artista, uma segurança e uma auxiliar de limpeza trouxeram familiares. Esta participação permitiu algo muito peculiar: no contato informal da educadora com os colegas de trabalho depoimentos espontâneos, que de outro modo não ocorreriam, puderam ser registrados. Uma funcionária da equipe de limpeza terceirizada que havia participado com os dois filhos, comentou posteriormente sobre o filho mais velho, de oito anos: "quando chegou em casa, ele contou tudo pro pai dele. Disse que não queria mais ser bombeiro, queria ser artista. Contou até como era onde o artista pintava, que tinha moldura para pendurar no museu. O pai achou importante ele voltar sempre. Quer até colocar a pintura dele num quadro na parede”.

Outra funcionária, analista acadêmica, mãe de uma menina de 5 anos, registrou na ficha de avaliação que os visitantes preenchem ao final das atividades:

\footnotetext{
A atividade pode estimular o interesse pelas obras de arte?

Sim, prova disso é que mesmo antes de terminar, minha filha já perguntou se poderá voltar.

Você gostou de tê-la acompanhado? Acha isso importante?

Sim, gostei e pretendo fazê-lo muitas vezes. Acho importante esse estímulo desde cedo.
}

Outro aspecto que podemos ressaltar sobre o programa Interar-te é o conhecimento dos participantes sobre arte contemporânea. A educadora teve a seguinte conversa com uma garota de 6 anos, sobre uma obra que não fazia parte da programação mas que despertou o interesse das crianças durante uma das oficinas:

\footnotetext{
(menina) - Aqui tem arte com umas coisas estranhas...

(educadora) - Pois é. E o artista pode fazer arte com estes materiais diferentes?

(menina) - Ah, ele tem uma ideia. Aí ele faz do jeito que ele acha melhor, né? Pra aquele ali dou o nome de plastical! [apontando obra de Sérgio Romagnolo na exposição Arte Contemporânea: Aquisições Recentes, em março de 2007]
}

Já o público adulto muitas vezes a considera a arte contemporânea estranha e esquisita. O pai de uma adolescente de 15 anos indagou sobre a obra Infância de Nina Moraes: “Ah, 
mas isso é arte? O que tem a ver uma coisa com outra? É muito discutível...”. Depois, produziu no ateliê um objeto complexo, cheio de significados metafóricos e abstratos, como a obra por ele incompreendida, e a realizou com materiais não tradicionalmente artísticos, mas sim do cotidiano.

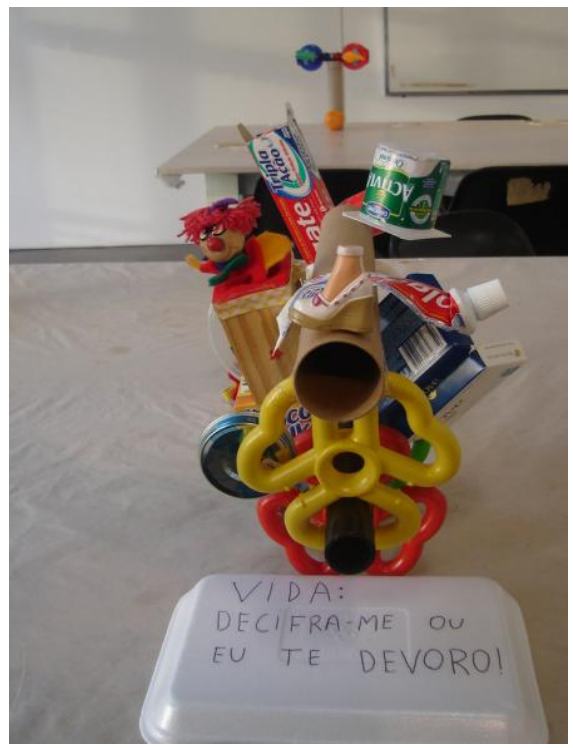

Figura 10 - Pelo orifício do cilindro de papelão avista-se a segunda parte da obra, ao fundo.

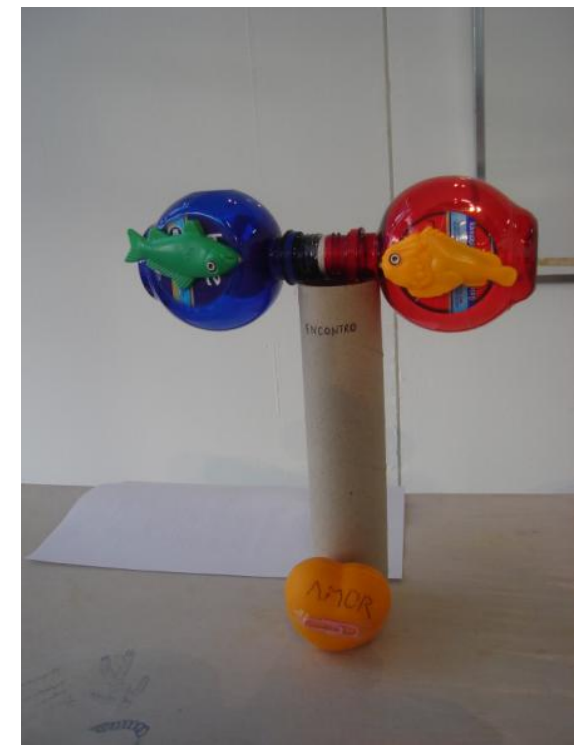

Figura 11 - A segunda parte da obra, com a questão "desencontros do amor", trazida por ele, representada pela palavra "encontro" escrita entre dois brinquedos com formato de peixe colados sobre garrafa pet, um de pontacabeça em relação ao outro.

Esse depoimento, somado ao do outro pai (citado à p.38) que acreditava ter que possuir habilidades manuais para participar da oficina, ressalta a afirmação de Iavelberg (2006, p.72): "Libertar-se dos cânones acadêmicos é importante para a orientação contemporânea (...)".

O Interar-te aproxima o público da arte contemporânea, não só por meio de suas estratégias educativas, propiciando a compreensão dos procedimentos utilizados em algumas obras apresentadas e dos processos de criação dos autores, mas também pelo contato com os próprios artistas, curadores e equipe técnica do Museu, pessoas ligadas em maior ou menor grau ao sistema das artes visuais. Beth Moysés e Carlos Delfino, dois dos artistas que participaram das sessões especiais realizadas no período estudado, ficaram surpresos com o comportamento do público. Moysés achava que os adultos interviriam na produção das crianças e surpreendeu-se com o envolvimento e o "mergulho" de todos. Constatou, na oficina que conduziu, que, independentemente da idade e do vínculo social ou afetivo, todos atuaram como colegas: representaram e discutiram a partir de suas próprias percepções. 


\subsection{Programas educativos para famílias em museus de arte}

O programa educativo Interar-te, do MAC-USP, certamente não é uma ação pioneira para famílias, nem haveria de ser no percurso fértil do setor educativo das instituições museais no país. Apresentamos, a seguir, sem no entanto fazer um apanhado extensivo, propostas educativas para famílias em museus e instituições culturais, ressaltando a ciência da diversidade de ações para o mesmo perfil de público no âmbito da educação não formal.

Na cidade de São Paulo, o Museu Lasar Segall oferece programações para famílias desde 1997. No ano seguinte a atividade foi interrompida ${ }^{28}$. De 1999 até o presente, o Museu realiza o programa Arte em Família mensalmente. Atualmente este programa é ofertado aos domingos. O Museu de Arte Moderna de São Paulo, também localizado no Parque Ibirapuera, oferece o Família MAM desde 2003 - nesse ano houve uma sessão especial no Dia das Mães $^{29}$. Ações para famílias constam dos relatórios anuais da instituição desde $1998^{30}$, nas atividades intituladas Minimam para crianças de 7 a 12 anos acompanhadas pelos pais, em tardes de sábados e domingos. O Família MAM é oferecido atualmente com ações relacionadas a obras em exposição no próprio MAM ou em consonância com a programação de outras instituições do Parque. Entre 2001 e 2002, aproximadamente, o Instituto Itaú Cultural realizou o Programa Compartilhar, no qual a pesquisadora atuou quando funcionária, monitora cultural, do Núcleo de Projetos Educativos da instituição.

Museus de arte internacionais também têm programas para famílias. Citamos as seguintes instituições como referência: os norte-americanos MoMA (Museum of Contemporary Art), de Nova Iorque, e o Chicago Art Institute, além dos europeus ThyssenBornemisza, em Madri, na Espanha, a Tate Modern, em Londres, na Inglaterra, e o Museu do Louvre e o Centre Pompidou, ambos em Paris, na França ${ }^{31}$. Algumas dessas instituições investem na produção de materiais de apoio para auxiliar famílias na obtenção de conhecimento sobre arte, tais como cadernos de atividades, livros e fantasias, além de oferecerem no sítio eletrônico da instituição instruções específicas para a visita ao museu em família.

Embora não se tenha explicitado as ações das instituições nomeadas acima para famílias, ressaltamos que são de alta qualidade em termos de educação sobre artes visuais. A

\footnotetext{
${ }^{28}$ Relatórios da Ação Educativa de 1997 e 1999. (Biblioteca MLS).

29 Mensagem de correio eletrônico de 06 de maio de 2003 entre imprensamam@mam.org.br e biblio@mam.org.br. (Biblioteca MAM SP).

${ }^{30}$ Relatório Geral-Anual MAM/SP, 1998. (Biblioteca MAM SP).

${ }^{31}$ Sobre os recursos e produtos educativos destas instituições francesas, vide o depoimento da Prof ${ }^{a}$ Dr $^{\mathrm{a}}$ Lisbeth Rebollo (Apêndice 4).
} 
respeito do que se considera educação sobre artes visuais de qualidade, compartilhamos das palavras da Prof ${ }^{\mathrm{a}}$. Maria Isabel Leite, da Universidade do Extremo Sul Catarinense, ideias que norteiam as ações do programa Interar-te. Para a professora, que é contundente na crítica ao uso de recursos de apoio à visita de uma exposição,

\begin{abstract}
Alguns museus, ao se abrirem explicitamente ao público infantil, esmeram-se em recursos quase circenses e pirotécnicos para atraí-lo. Quando se objetiva levar crianças às exposições, normalmente se cria uma atividade anterior, um "chamariz", uma "sedução" para atrair a presa à sua jaula - teatros, danças, filmes, brincadeiras ligadas ao pintor cuja obra está exposta... Será que precisamos criar "iscas" ou "disfarces" para as crianças se interessarem pelos espaços culturais? Parece que a obra como tal não é suficientemente atrativa. Mas coloco uma questão: os fins justificam os meios? Isto é: devemos fazer teatro de fantoches, jogos etc. e atrair o público abrindo uma possibilidade de experiência estética com as obras de arte, ou permanecer firmes no princípio de que as obras, por si, devem continuar sendo o foco central e serem atrativas por elas próprias? (LEITE \& OSTETTO, 2005, p.29)
\end{abstract}

Compreendemos suas palavras e concordamos que o excesso de recursos, de referências ou mesmo de atividades são desnecessários quando substituem a experiência do contato com as obras. No entanto reconhecemos que, bem dosados, estes elementos facilitam a contextualização e podem favorecer o conhecimento e a experiência do público com as exposições. 


\section{A COMPREENSÃO DE LAZER}

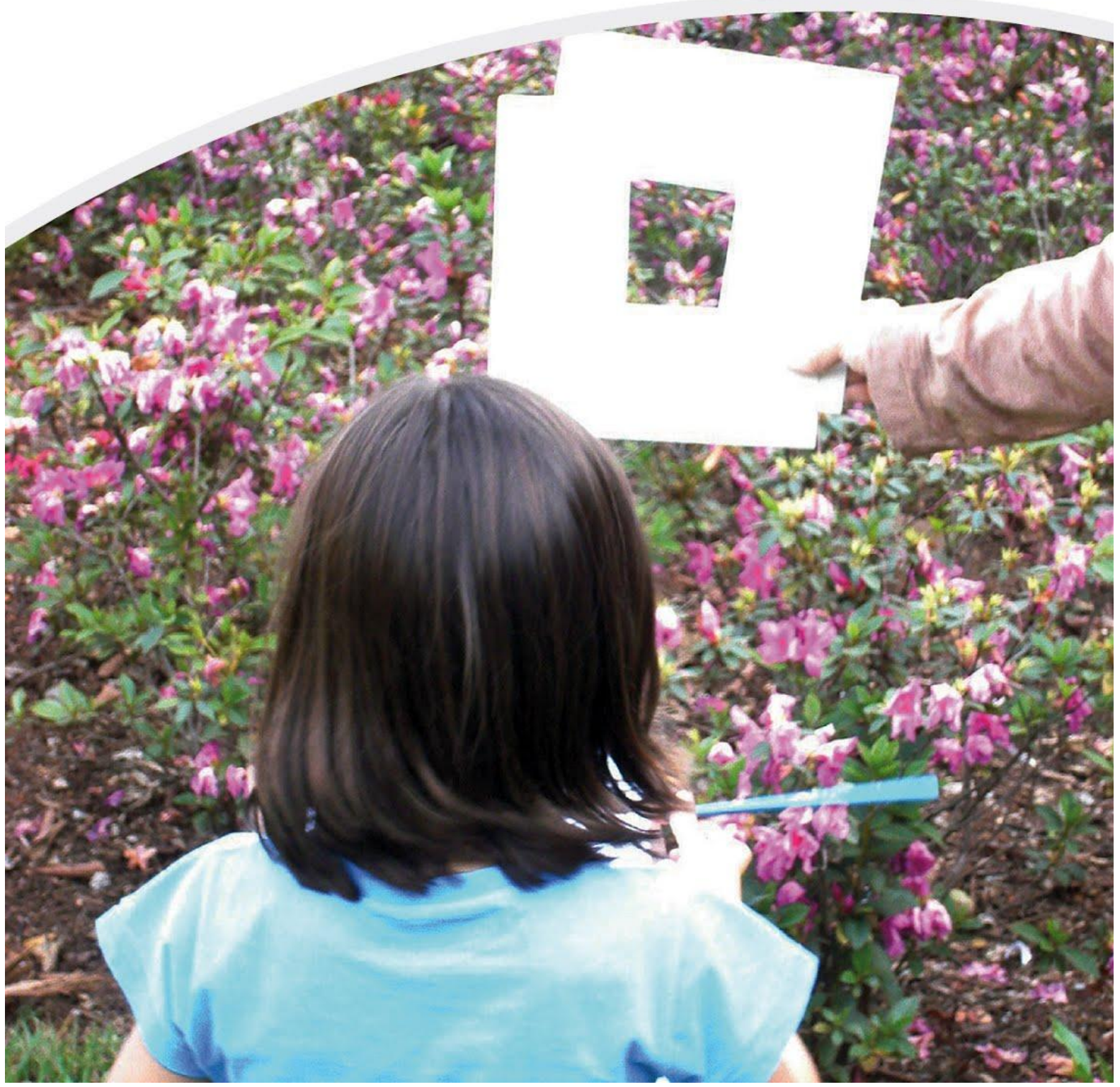

Figura 12 - Mãe auxilia filha a selecionar uma vista para realizar um desenho de observação durante a oficina do Interar-te Quantas cidades nessa mesma São Paulo na exposição Radiografias da cidade, em agosto de 2007. 


\section{A COMPREENSÃO DE LAZER}

\subsection{Tempo humano de trabalho e de não trabalho: localizando as atividades de ócio}

Para analisar a relação entre entretenimento e educação diante dos propósitos do Interarte - programa que oferece atividades a agrupamentos familiares em seus momentos de lazer e que gera aproximações e conhecimentos em artes visuais, dada a especificidade da instituição que o promove -, recorreremos a autores que discorrem sobre a educação no tempo livre.

Ócio e trabalho sempre estiveram presentes nas sociedades humanas; como fato social e objeto de reflexão, Puig e Trilla (1996) ressaltam que o significado dessa relação, que também é uma elaboração humana, acompanha as diferenças e semelhanças entre essas sociedades em cada época.

Cientes dessa diversidade, optamos por apontar concepções e considerações mais recentes acerca dessa relação, no intuito de fornecer subsídios ao contexto no qual o objeto de pesquisa está inserido. Trataremos da problemática moderna do ócio pós-Revolução Industrial e no âmbito de países de organização econômico-política capitalista.

Então, o que se entende por ócio?

O fenômeno do ócio implica sempre um marco temporal. Distinguimos e opomos o tempo que dedicamos ao trabalho do tempo livre. O ócio supõe a liberação das obrigações do trabalho e a disponibilidade pessoal do tempo. Mas o ócio não é sinônimo de tempo livre. O tempo livre é unicamente uma condição necessária, mas não suficiente. Muitas vezes, utilizam-se equivocadamente ambos os termos com sentidos equivalentes.

O ócio requer e se configura também a partir de outro tipo de condições. Cria-se uma situação de ócio quando o homem, durante seu tempo livre, decide e gestiona livremente suas atividades, obtém prazer e satisfaz necessidades pessoais, como descansar, se divertir ou se desenvolver. (PUIG \& TRILLA, 2004, p.21)

Essa definição é aproximada à que selecionamos do sociólogo francês Joffre Dumazedier, embora já revista por ele próprio:

(...) o ócio é um conjunto de ocupações às quais o indivíduo pode se dedicar de maneira totalmente voluntária, seja para descansar, se divertir, desenvolver sua informação ou sua formação desinteressada, sua participação voluntária, após se libertar de obrigações profissionais, familiares e sociais. (PUIG \& TRILLA, 2004, p.36)

A dicotomia primordial dessa relação é a existente entre o tempo de trabalho e o tempo de não-trabalho, dedicado às atividades livres e ao ócio; porém, ressalta-se que ócio não é sinônimo de tempo livre. O tempo é uma das indicações do ócio, mas não a determina. No tempo do não-trabalho há a dedicação a outras obrigações: as "paraprofissionais" (o tempo gasto no transporte é um exemplo), familiares, religiosas e políticas. Estes dois últimos fatores 
são questionados por alguns autores, porém se configuram como momentos de menor disponibilidade pessoal e não serão considerados como momentos de ócio dada a perspectiva acima citada, da qual compartilharemos.

Deste modo, além da distribuição do tempo, somam-se outros fatores quando da caracterização do ócio: a atitude com a qual se vive o tempo, a liberdade de escolha e a forma pela qual se pratica o que se escolhe. Outro aspecto importante é a satisfação de necessidades pessoais durante as atividades do tempo livre, como a de se desenvolver, que corresponde ao ócio ativo. Nesse sentido, o tempo livre pode ser utilizado para o aprimoramento pessoal em áreas de interesse. Mas, em que medida numa sociedade com forte influência dos meios de comunicação de massa, as escolhas das atividades com o propósito do entretenimento são realmente livres, partem do interesse pessoal ou são desvinculadas do consumo alienado?

\begin{abstract}
O ócio era considerado um tempo antieconômico, já que não facilitava o acúmulo de capital. Essas opiniões foram mudando lentamente conforme o tempo livre foi se impondo como uma realidade social e adquirindo uma função econômica nova e mais positiva. $\mathrm{O}$ aumento do tempo livre começava a significar um considerável aumento do tempo de descanso dos trabalhadores. Ou seja, adquiria utilidade econômica, pois favorecia uma melhora nas condições de vida e força de trabalho. Além disso, numa etapa superior, o tempo livre servirá também para melhorar a capacitação profissional dos trabalhadores. Portanto, como descanso ou formação pessoal, o tempo livre começa a ser apreciado pelos economistas. Finalmente, com a chegada das sociedades de consumo massivo, como defende e apregoa o primeiro Riesman, o ócio adquire um novo sentido, enquanto tempo liberado da produção e disponível para o consumo. Consumo que, além de cumprir a função social de adaptação às novas necessidades, estimula também o desenvolvimento das forças produtivas. A obra de Riesman representa o reconhecimento definitivo dessa função do ócio. (PUIG \& TRILLA, 2004, p.31)
\end{abstract}

\title{
3.2. Educação no tempo de ócio
}

Diante de problemas socioeducativos presentes na última década do século XX, como os decorrentes das tecnologias de informação, da desigualdade de disponibilidade temporal, da crise socioeconômica e os graves problemas de desemprego e reorganização administrativa e de produção, das alterações nas relações sociais de trabalho, além do crescimento populacional e aumento demográfico da terceira idade, da fome, dos estados de guerra e préguerra, da violência e da dependência de drogas, o pedagogo espanhol Alexandre Sanvisens i Marfull (PUIG \& TRILLA, 2004, p.11) indaga: que tipo de educação se requer para ocupar adequadamente o tempo disponível e enfocar conveniente preparação técnica e humana diante do futuro? E afirma: a educação tem um papel ecológico a cumprir.

Com vistas ao quadro apresentado, que em grande parte pode ser estendido ao panorama do início do século XXI, qual seria o papel da educação no tempo de ócio? 


\begin{abstract}
Os trabalhos carentes de responsabilidade e iniciativa, além do desgaste psíquico que provocam, costumam conduzir a ócios passivos, consumistas e padronizados. Por outro lado, a influência do trabalho no ócio expressa-se também na forma como as diferenças profissionais marcam as atividades e costumes de ócio. Os ócios não fazem desaparecer a divisão do trabalho nem a diferença de meios econômicos. As diferenças culturais e de iniciativa pessoal tampouco se alteram significativamente no ócio. Por último, mesmo que menos importante, a idade ou o local de moradia são traços diferenciais que também se manifestam no ócio. Por todos esses motivos, parece lógico defender a tese da influência do mundo profissional no tempo livre. (PUIG \& TRILLA, 2004, p.34)
\end{abstract}

Se, na amostra de adultos selecionados para esta pesquisa, essa premissa puder ser comprovada, o papel da educação pela família será ratificado na ampliação do leque de opções de ócio, pois as referências da família de origem (ROMANELLI, 1986) poderão influenciar no repertório de opções que ficariam estagnados por motivos de demandas de trabalho e do tempo livre.

O sociólogo francês Georges Friedmann (apud PUIG \& TRILLA, 2004, p.33) afirma que, em uma metrópole com o ritmo de vida acelerado como São Paulo - grande parte da população empregada em trabalhos psiquicamente desgastantes, os apelos da indústria cultural que promove o consumo de produtos com fim em si e que não investem na formação dos consumidores -, teremos um cenário que pode alimentar a alienação, o trabalho não criativo, mecânico, repetitivo e fragmentado. Nesse cenário, ações que proporcionem "ócios de mais qualidade" são de vital importância. Deste modo cremos ser necessário refletir como o lazer é afetado pela programação cultural numa sociedade de massa, onde a mídia tem forte poder de influência sobre as opções das famílias. Qual a relação entre lazer e consumo de eventos, produtos da indústria cultural?

É preciso construir uma sociologia do ócio que considere os problemas práticos enfrentados em todos os níveis quando se quer aplicar um projeto de democratização social e cultural. Dumazedier pensa que o tempo de ócio é idôneo para desenvolver planos de ação sociocultural destinados a fazer compreender, recriar e criar cultura: fazer do ócio um tempo de educação. (PUIG \& TRILLA, 2004, p.38)

Ao encontro dessas reflexões acerca da ampliação do conceito de educação, Puig e Trilla discutem que houve ampliação tanto "vertical: considerava-se a infância e a juventude etapas quase exclusivas da ação educativa, mas se passou a entender que a pessoa pode ser educada durante toda a sua existência", como:

horizontal: não apenas escola e família são agentes educativos, mas se educa a partir de muitas outras instituições, meios e âmbitos que nem sempre são reconhecidos como especificamente educativos: trata-se dos conceitos de educação informal, educação não-formal e outros paralelos ou similares, que ultrapassam os limites do que, antes, era considerado educação. (PUIG \& TRILLA, 2004, p.58) ${ }^{32}$

\footnotetext{
${ }^{32}$ No âmbito da pesquisa tratamos das relações entre a família (educação informal) e o museu (educação nãoformal), com considerações pontuais sobre o ensino de arte na escola (educação formal) no capítulo 6 Resultados e discussão dos dados coletados.
} 


\section{A COMPREENSÃO DE FAMÍLIA}



Figura 13 - Elaboração de uma máscara do rosto da mãe durante oficina do Interar-te Quem é você (hoje)? na exposição MAC Contemporâneo - Instalações, em outubro de 2008. 


\section{A COMPREENSÃO DE FAMÍLIA}

\subsection{A família em atividade de ócio em um museu de arte}

O papel da família é essencial para que seus membros, principalmente crianças e adolescentes, vislumbrem possibilidades de ócio, fato que investigaremos e será tratado posteriormente ao apresentarmos a metodologia da pesquisa.

Puig e Trilla (2004, p.126) afirmam que "os hábitos que a família construirá sobre essas atividades costumam ser de grande importância para os filhos e para satisfação futura que encontrarão no tempo livre"; e citam o sociólogo Pierre Fougeyrollas 33: "a família e a escola são as duas instituições fundamentais para a custódia da infância. A família, além de unidade econômica, afetiva, social, etc., constitui uma comunidade de ócios”. (apud PUIG \& TRILLA, 2004, p.56) Ainda: “A maior parte da atividade de tempo livre infantil transcorre no meio familiar. Tanto no que se refere aos ócios cotidianos como aos semanais e anuais (fins de semana, férias, etc.), a família era a instituição que determinava sua forma e conteúdo" (PUIG \& TRILLA, 2004, p.57), mas os autores fazem a ressalva de que isso estava vinculado às famílias nucleares e mudou com transformações sociais que atingiram as dinâmicas familiares, como a maior participação da mulher em:

[...] trabalho fora de casa, um grande relaxamento nas relações intrafamiliares, uma progressiva desvinculação da família (pais e filhos) com outros membros familiares (avós, etc.), a busca de níveis mais amplos de autonomia pessoal de cada membro do grupo foram mudando a imagem da família como comunidade de ócios. (PUIG \& TRILLA, 2004, p.57)

Puig e Trilla (1974, p.19) afirmam que atualmente há a delegação parcial dessa responsabilidade a instituições como brinquedotecas, clubes infantis e colônias de férias, acreditamos que a ocorrência maior de agrupamentos familiares não nucleares não significa a descaracterização da importância da família na formação e educação de crianças e jovens. Discorreremos sobre esse fator em outro momento da pesquisa, mas adiantamos que a cientista social Cynthia Andersen Sarti (2009, p.85-86) aponta que em alguns grupos familiares o vínculo é estabelecido pela qualidade da relação entre seus membros e não pelo parentesco consanguíneo. Ou seja, a existência de diferentes arranjos familiares ressalta a importância de atividades de ócio de mais qualidade e o papel dessas atividades na promoção de integração dos novos agrupamentos.

\footnotetext{
${ }^{33}$ FOUGEYROLLAS, P. La família, comunidad de ócios. In: DUMAZEDIER, I. e outros: Ocio y sociedad de classes. Barcelona, Fontanella, 1971, pp.167-182.
} 
Puig e Trilla dividem as atividades de ócio em quatro grandes grupos. Um primeiro relacionado ao físico, com predominância de atividades corporais como esportes, excursões e passeios; um segundo onde predominam a produção pela prática de trabalhos manuais em que bricolagem e jardinagem são exemplos; um terceiro que inclui todas as práticas culturais, sejam de elite ou de massa, criativas ou passivas; e um quarto grupo que se caracteriza por atividades de caráter social ou coletivo, com predominância de relações interpessoais, como encontros e festas, ida a locais públicos como praças, clubes ou cafés e ainda a vida familiar. O terceiro grupo contempla as ações do programa Interar-te.

Considerando que atividades de ócio podem ter caráter de formação pessoal, acreditamos que o programa Interar-te do MAC USP cumpre esse papel em relação à opção das famílias que o frequentam. Desde o início das atividades desse programa educativo, não houve solicitação de inscrição prévia. Por se tratar de uma atividade em momento de lazer, a presença não deveria ser garantida por intermédio de compromisso assumido com a instituição, mas sim pela disponibilidade e motivação do próprio grupo familiar naquele dia.

Visando o convívio familiar, as atividades propiciam o contato com obras de arte que, mesmo partindo das memórias do grupo, promovem situações de conhecimento de procedimentos artísticos e da história da arte. Diante desse quadro, qual a contribuição da ação educativa de um museu à formação da população nos momentos de não trabalho e demanda não escolar?

Talvez um dos fenômenos mais críticos de que trata a educação, hoje, é o que promove o grande âmbito, cada dia mais amplo e intenso, das demandas educativas, escolares e não escolares, com relação à comunicação e à expansão da cultura. A educação não tem limites definidos por idade ou pela escola, pelos deveres profissionais ou pela relação circunstancial de cada um; estende-se e se aplica a todos sempre, sincrônica e diacronicamente. Os grandes meios de comunicação colocam ao alcance de todo o mundo os benefícios - e, às vezes, os malefícios - da cultura. O homem, os grupos, os coletivos humanos, as comunidades e a sociedade em geral podem participar mais intensamente do que nunca da socialização e da educação. Mas se torna clara a necessidade de sermos conscientes desse fenômeno e de conduzi-lo em nosso benefício e de todos. Por outro lado, é preciso que, da maneira correta, todos participem da aquisição da cultura e da formação, sem situações de privilégio promovidas pela posição territorial, econômica, social, religiosa, política, profissional ou de qualquer outra ordem. A educação é direito do homem, inalienável, sem exceção, individual, familiar, social... hoje e sempre. Se em alguma época houve discriminação, é hora de proclamar e defender esse direito tão importante, adotando todas as medidas para concretizá-lo, em nível pessoal e coletivo. (PUIG \& TRILLA, 2004, p.12)

Pensamos ser esse o intuito dos adultos que buscam propiciar às suas famílias atividades em um museu de arte em seus momentos de lazer. Mas quais as motivações dessas pessoas? Uma hipótese, baseada nas ideias de Romanelli (1986) é a de que se trata de pessoas cujas representações simbólicas incluem aspectos de valorização da educação e da formação 
de hábito de fruição da cultura, através das vivências em grupo. Estariam estes valores incluídos nos hábitos criados pelas famílias de origem desses adultos? Ou, ainda, estes valores seriam influenciados pelas experiências recentes dessas pessoas, atreladas ao trabalho? Qual o papel da família nas atividades de tempo livre?

Primeiro, a responsabilidade de organizar e ensinar os filhos a organizar o tempo recai em grande parte sobre as famílias. Não é possível o ócio, se não tiver ficado claro e disponível um espaço de tempo livre de qualquer tipo de obrigação. A família é responsável pelo tempo que o filho não ocupa indo à escola. Ela define quais obrigações ocuparão o tempo não-escolar e qual será também o tempo que ficará completamente para os filhos, o tempo que não é empregado para satisfazer necessidades ou cumprir obrigações impostas. Pensamos que uma boa educação para o ócio garantirá que todos disponham livremente de uma parte de seu tempo. Em consequiência, os pais permitirão que os filhos tenham tempo livre. Tempo este em que deverão aprender e se organizar. Uma condição tão elementar da ação educativa da família é muitas vezes esquecida. Os pais temem o tempo livre dos filhos. Buscam de toda forma enchê-lo de obrigações mais ou menos interessantes e educativas. Pretendem que os garotos tenham todo o tempo ocupado, desde a saída da escola à hora de voltar para a sala de aula. Tais espaços de tempo são preenchidos com cursos complementares, televisão e outras atividades. Ocupações que nem sempre são intrinsicamente más, mas que muitas vezes têm apenas o objetivo de ocupar o tempo dos filhos. Tais atividades são positivas sempre que não requeiram um esforço físico e mental pouco recomendável depois do que se faz na escola, mas que respondam a uma necessidade dos filhos e, se possível, sejam livremente escolhidas por eles. Seja como for, uma boa pedagogia do ócio implica respeitar e ampliar o tempo livre disponível. Obviamente, não cremos que seja positivo o aborrecimento que poderia ocorrer no caso de se dispor de muito tempo livre desorganizado. Trata-se de aprender a organizar o próprio tempo livre e fazer dele um tempo de autodesenvolvimento. (PUIG \& TRILLA, 2004, pp.125-126)

As propostas do Interar-te partem de obras em exposição no Museu. As atividades são orientadas pela equipe de educadores, embora haja o intuito de deixá-las abertas às referências e interpretações do público e a sua ressignificação. As memórias dos adultos, as experiências com a família, as interpretações, são favorecidas no conjunto das ações educativas.

\subsection{Família? Famílias...}

Quem são os adultos dos agrupamentos familiares que frequentam o programa Interarte do MAC USP? São mães e pais, em sua maioria, porém algumas crianças e jovens vêm acompanhados por tios, avós, madrastas, padrastos, vizinhos e pais de amigos dos filhos, ou seja, grupos com perfis bem diversificados. Tanto familiares quanto amigos da família têm sido os condutores e acompanhantes das crianças e jovens. Isso, muitas vezes, havia deixado dúvidas na caracterização do público no âmbito da própria divulgação institucional - a quem se referir como público-alvo? Famílias? Mas, o que se entende por família? 
Embora até então o programa tenha sido divulgado para famílias, numa concepção leiga, sempre foram aceitos para as atividades os agrupamentos compostos por adultos e crianças ou jovens, independentemente do vínculo entre seus membros, fosse de parentesco ou não. Dizia-se que o conceito de família estava estendido e o que importava era a participação do adulto junto aos mais jovens. Porém esta orientação estava de acordo com conceitos atuais sobre os diferentes arranjos familiares.

Nesse sentido, Sarti (1996, pp.85-86), apesar de se referir a camadas específicas da população, nos aponta a possibilidade de compreensão dos agrupamentos familiares em geral que certamente estiveram presentes no Interar-te e foram considerados como familiares, pelos princípios morais da reciprocidade e da confiança, mesmo sem a relação de parentesco entre seus membros:

A família, para os pobres, associa-se àqueles em quem se pode confiar. Sua delimitação não se vincula à pertinência a um grupo genealógico, e a extensão vertical do parentesco restringe-se àqueles com quem convivem ou conviveram, raramente passando dos avós. (...) Como não há status ou poder a ser transmitido, o que define a extensão da família entre os pobres é a rede de obrigações que se estabelece: são da família aqueles com quem se pode contar, isto quer dizer, aqueles que retribuem ao que se dá, aqueles, portanto, para com quem se tem obrigações. São essas redes de obrigações que delimitam os vínculos, fazendo com que as relações de afeto se desenrolem dentro da dinâmica das relações descritas neste capítulo.

A noção de família define-se, assim, em torno de um eixo moral. Suas fronteiras sociológicas são traçadas a partir de um princípio da obrigação moral, que fundamenta a família, estruturando suas relações. Dispor-se às obrigações morais é o que define a pertinência ao grupo familiar. A argumentação deste trabalho vai ao encontro da de Woortmann (1987), para quem, sendo necessário um vínculo mais preciso que o de sangue para demarcar quem é parente ou não entre os pobres, a noção de obrigação torna-se central á idéia de parentesco, sobrepondo-se aos laços de sangue. Essa dimensão moral do parentesco, a mesma que indiferencia os filhos de sangue e de criação, delimita também sua extensão horizontal. Como afirma Woortmann (1987), a relação entre pais e filhos constitui o único grupo em que as obrigações são dadas, que não se escolhem. As outras relações podem ser seletivas, dependendo de como se estabeleçam as obrigações mútuas dentro da rede de sociabilidade. Não há relações com parentes de sangue, se com eles não for possível dar, receber e retribuir.

Como bem pontua Sarti, de que adianta alguém considerar pessoas como membros familiares, apenas pelo parentesco entre eles, se nas horas mais difíceis com eles não se pode contar? Afinal, como é apontado poeticamente na canção Família ${ }^{34}$, de Arnaldo Antunes e Tony Bellotto, do grupo de rock Titãs, se o vínculo é questionado ou alargado quando do surgimento de conflitos, ele não é tão forte, mesmo sob justificativas das mais arraigadas à cultura dos parentes em questão.

\footnotetext{
${ }^{34}$ Letra disponível em: <http://letras.terra.com.br/titas/48973/>. Acesso em: 29 jun. 2009.
} 


\section{REFERENCIAL METODOLÓGICO}

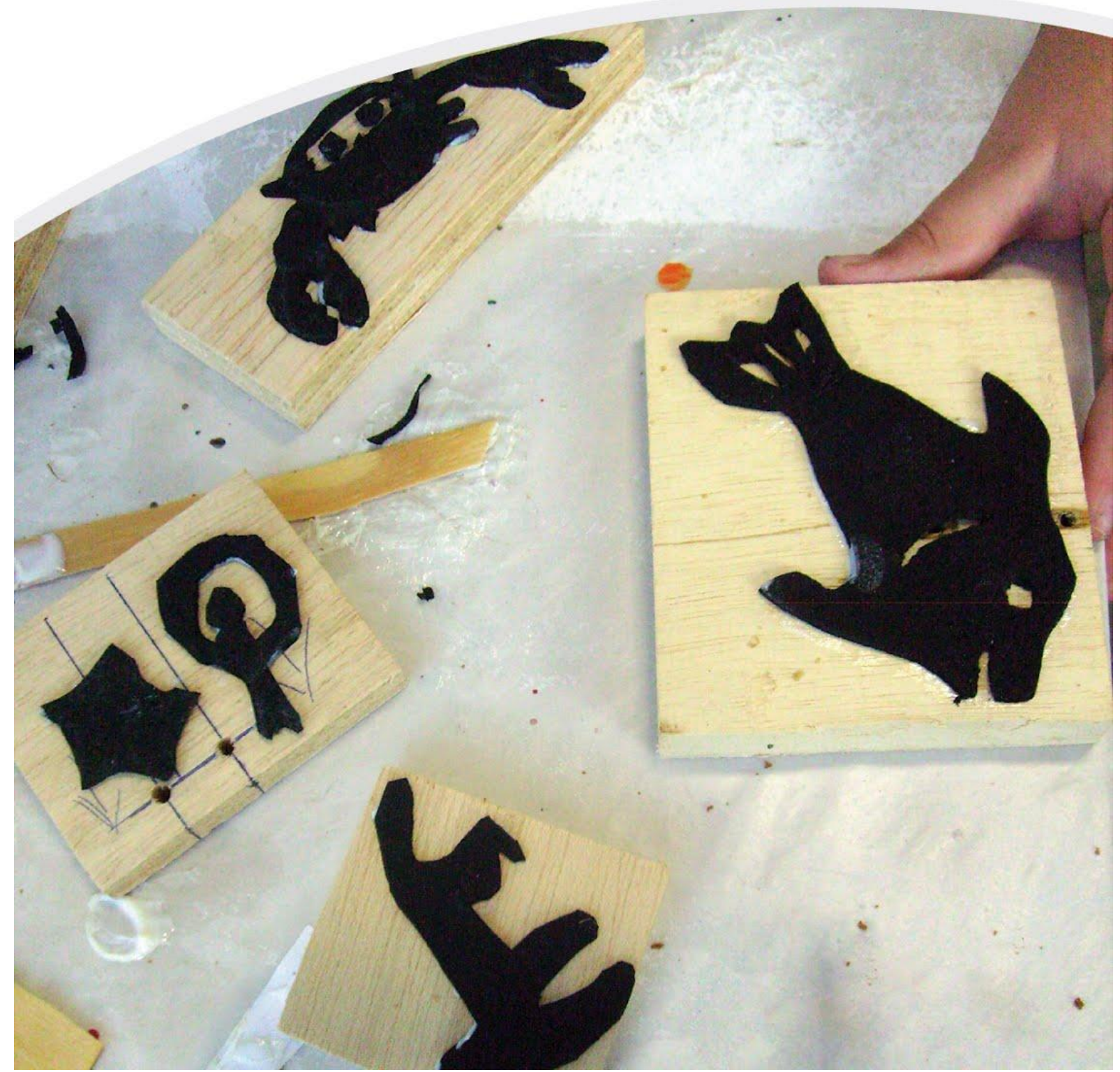

Figura 14 - Carimbos criados por menino de 11 anos durante a oficina do Interar-te Eu quero um bichinho de estimação! na exposição Coleções sob a guarda provisória do MAC USP, em março de 2010. 


\section{REFERENCIAL METODOLÓGICO}

\subsection{Problema da pesquisa}

Os objetivos da pesquisa "Famílias no museu de arte: lazer e conhecimento - um estudo sobre o programa educativo Interar-te do MAC USP" são: 1. conhecer as motivações dos adultos que buscam, em seus momentos de lazer, propiciar a crianças e jovens atividades em um museu de arte e 2. conhecer as aspirações desses adultos em relação aos resultados que esperam das experiências que proporcionam aos mais jovens. São eles habituados a frequentar museus de arte sozinhos? Quem os levava a museus em sua infância? Se a origem deste hábito não está na relação com a família, o que os motiva a irem a essas instituições com crianças e adolescentes na atualidade?

O papel de protagonistas dos adultos na formação de hábitos culturais da família estará evidenciado se a análise dos dados coletados em campo demonstrar que são eles quem determinam a escolha pela frequentação a museus de arte. Pressupõe-se que trata-se de pessoas que valorizam a educação dos filhos em detrimento do consumismo (BAUMAN, 2008, pp.37-69) de espetáculos e eventos atrelados à indústria cultural, de grande porte e com apelo nos meios de comunicação de massa (parques temáticos, oficinas de shopping centers, peças teatrais e shows). O MAC USP é um museu universitário e sua programação está em um ritmo diferente da de instituições atreladas ao capital de patrocinadores; não possui tanto destaque na mídia se comparado a eventos relacionados a exposições blockbusters.

Se a influência dos adultos nos hábitos de frequentação a museus for confirmada, a pergunta que segue é: até que idade essa ascendência predomina sobre a escolha dos jovens? Por que adolescentes participam das atividades? Se forem eles, os adolescentes, quem escolhem participar de atividades culturais, por que o fazem? Terão criado o hábito espelhando-se no papel formador dos adultos que os acompanham desde crianças? Ou, ainda, como as famílias equilibram os interesses pelas opções de puro entretenimento com outras de cunho educativo e de formação de repertório artístico-cultural?

É possível constatar se as atividades do Interar-te contribuem para a formação de público frequentador de museus e ampliam os conhecimentos em artes visuais dos familiares de todas as idades. E é possível constatar se o Interar-te tem sucesso em seu outro objetivo: promover o estreitamento dos laços dos integrantes de um mesmo grupo familiar? Os 
participantes têm notado diferenças na qualidade dos vínculos da família quando da frequentação ao programa? Ele realmente promove interação entre os participantes?

A importância da participação e convivência dos adultos em programas educativos para famílias foi percebida pela pesquisadora e educadora responsável pelo programa Interarte em uma experiência profissional anterior em outra instituição cultural localizada em uma avenida comercial de grande movimento e próxima a um shopping center. Houve, entre 2001 e 2002, uma programação de atividades para famílias em que esta pesquisadora pôde verificar que, não raro, os adultos não queriam acompanhar as crianças durante as oficinas, mas delegálas aos cuidados da equipe de monitores para realizarem atividades fora da instituição. Embora as atividades não fossem especificamente direcionadas aos adultos, estes poderiam participar.

\subsection{Método}

A pesquisa "Famílias no museu de arte: lazer e conhecimento - um estudo sobre o programa educativo Interar-te do MAC USP” insere-se no campo das investigações qualitativas, sendo os dados coletados predominantemente descritivos. Esta opção metodológica não descarta o levantamento de informações quantitativas. ${ }^{35}$ (BOURDIEU, 2008; FERNANDES, 2009)

Esta pesquisa consiste de um estudo de caso, indicado segundo André (1995, p.51):

(1) (...) quando as perguntas da pesquisa forem do tipo 'como' e 'por quê'; (2) quando o pesquisador tiver pouco controle sobre aquilo que acontece ou que pode acontecer; e (3) quando o foco de interesse for um fenômeno contemporâneo que esteja ocorrendo numa situação de vida real.

Ainda segundo André (1995, p.54), “[...] os estudos de caso podem fornecer informações valiosas para medidas de natureza prática e para decisões políticas”, o que justifica a escolha do programa educativo Interar-te para a obtenção da amostra, pois os resultados desta pesquisa podem se reverter como benefício à própria instituição, como avaliação de aspectos relacionados ao público-alvo. A pesquisadora é educadora do MAC USP e responsável pelo programa Interar-te, o que facilita o feedback ao museu.

Utilizou-se estratégias de análise do material coletado pelos instrumentos de pesquisa selecionados visando eleger categorias e sub-categorias passíveis de interpretações, com

\footnotetext{
${ }^{35}$ Por exemplo, para a classificação econômica das famílias foram utilizados questionários fechados; quadros e gráficos foram gerados para a quantificação de dados colhidos nas entrevistas semi-estruturadas.
} 
cruzamentos entre as mesmas e por triangulação $0^{36}$, assim como pelas observações registradas pela própria pesquisadora acerca da realidade que a ela se apresentou. (BARDIN, 1977)

Para triangulação de informantes e $\operatorname{sujeitos~}^{37}$ (GÓMEZ, 1999) com os adultos - a amostra que se constitui como o objeto desta pesquisa -, foram colhidos depoimentos das crianças e jovens dos mesmos agrupamentos familiares. Complementarmente, não constituindo amostragem para a pesquisa, foram entrevistados educadores assistentes (estagiários ou bolsistas que atuaram no Interar-te no período do estudo) ${ }^{38}$ e a ex-diretora do MAC USP Lisbeth Rebollo, que motivou diretamente a concepção do programa Interar-te.

Sendo assim, foram constituídos como instrumentos para a investigação empírica, diante de estratégias de triangulação metodológica ${ }^{39}$ (GÓMEZ, 1999):

- entrevista semiestruturada com adultos dos agrupamentos familiares e, quando passíveis de serem entrevistados, com crianças e jovens que os acompanharam (se residentes no mesmo lar ou se familiares próximos);

- desenho das crianças com idade entre 5 e 12 anos, como técnica de apoio a uma das questões da entrevista;

- questionário fechado sobre índice de classificação econômica para os adultos. Este instrumento foi utilizado para verificar as facilidades e dificuldades das famílias na frequentação ao museu devido às condições econômicas (gastos com transporte, alimentação e tempo de deslocamento);

- entrevista por grupo focal ${ }^{40}$ e questionário aberto orientado aos educadores assistentes (estagiários e bolsistas) que atuaram no programa Interar-te no período estudado;

- entrevista semiestruturada com a ex-diretora do MAC USP Lisbeth Rebollo.

As entrevistas foram gravadas em áudio e transcritas pela pesquisadora.

O sigilo da identidade dos entrevistados dos agrupamentos familiares lhes foi assegurado. As entrevistas e o questionário de classificação econômica com informações prestadas pelas famílias (adultos, crianças e jovens) seguem como apêndices na pesquisa sob o modo de formulário, sem as respostas. Os dados coletados são apresentados sob a forma de

36 “Triangulação. A prática de comparar resultados de dados destinados a medir o mesmo construto, mas coletados de diferentes fontes e/ou por diferentes métodos para aumentar a certeza da validade do construto. Glossário In: Avaliação de programas: concepções e práticas.” (WORTHEN, SANDERS \& FITZPATRICK, 2004, p.703)

37 "A triangulação de informantes e sujeitos: conhecer e contrastar os múltiplos pontos de vista que se conjugam numa mesma circunstância constitui uma prática recomendável e essencial, que pretende aproximar-se de um entendimento profundo da realidade que permita interpretações justificadas." (GONZAGA, 2006, p.87)

${ }^{38}$ Seis dos sete educadores assistentes envolvidos estiveram presentes na entrevista por grupo focal. A ausência deveu-se a falecimento de familiar.

39 "A triangulação metodológica se produz: em duas direções. Por um lado se conjugam dados de natureza qualitativa, por outro, quantitativa." (GONZAGA, 2006, p.87)

40 "Grupos focais. Um método de entrevista em grupo destinado a obter informações que resultam da interatividade orientada dos membros do grupo; produz tipos de informação diferentes dos obtidos em entrevistas tradicionais a dois ou em entrevistas estruturadas em grupo." (WORTHEN, SANDERS \& FITZPATRICK, 2004, p.698) 
quadros, gráficos, mapa e citação de depoimentos neste capítulo, quando da análise do corpus da pesquisa. As entrevistas com a equipe do MAC USP (ex-diretora e educadores assistentes) estão anexadas na íntegra, como apêndices, mas apenas a ex-diretora tem seu nome revelado junto aos depoimentos.

\subsection{Procedimentos}

As entrevistas dos agrupamentos familiares, constituídos apenas pelos adultos ou pelos adultos acompanhados de criança(s) ou jovem(s), foram realizadas após a apresentação de imagens digitais nas quais eles podiam visualizar momentos de sua participação no programa. Este recurso foi muito útil sob vários aspectos: promoveu maior aproximação entre os entrevistados e a pesquisadora mostrou-se eficaz quanto à ativação da memória dos entrevistados. As imagens (fotos) foram um estímulo (DELVAL, 2002, p.92) e delimitaram o foco da pesquisa, auxiliando na abordagem de questões pontuais sobre o programa educativo.

Sendo os adultos o objeto da pesquisa, a eles foi direcionada a maioria das questões da entrevista semiestruturada elaborada para os agrupamentos familiares.

No início do trabalho de campo percebeu-se que quando havia crianças era mais produtivo iniciar a entrevista com elas, para evitar que ficassem impacientes e passassem a interromper os adultos. Depois da participação, elas ficavam próximas e, mesmo quando se dedicavam a outras atividades, intervinham quando achavam necessário ou podiam ser abordadas pelo adulto ou pela pesquisadora. Isso evitou que a curiosidade natural e a ansiedade das crianças frente à situação de entrevista atrapalhassem os adultos.

A participação da pesquisadora como educadora responsável pelo planejamento, execução e avaliação do Interar-te favoreceu a compreensão de aspectos das respostas dos entrevistados que não ficariam claros de outra maneira. Esta proximidade favoreceu redirecionamentos e aprofundamentos de questões durante as entrevistas. Outra facilidade que a proximidade da pesquisadora ao caso estudado proporcionou foi o levantamento de informantes para triangulação. E, ainda, o vínculo estabelecido com os entrevistados, que, por isto, sentiram-se motivados a contribuir sem se sentirem intimidados diante de uma pesquisadora. (BOURDIEU, 2008)

O processo de elaboração da entrevista contou com um estudo-piloto, no qual a entrevista estava muito longa, com questões repetitivas ou subentendidas em anteriores. 
Algumas questões foram reelaboradas, outras foram mantidas para confirmação de dados; estas últimas foram evitadas quando já respondidas pelo entrevistado.

Outra estratégia, advinda de estudos sobre o método clínico em pesquisa com crianças e utilizada em entrevistas com agrupamentos quando elas estavam presentes, foi a solicitação de desenhos. Este recurso de apoio foi utilizado com participantes de idade entre 5 e 12 anos como complemento às questões que lhes foram dirigidas em entrevista. Sobre a limitação da idade para a solicitação do desenho Delval (2002, p.95) explica que:

A partir dos 12 ou 13 anos, essa técnica começa a perder sua utilidade, pela relação
que os sujeitos têm com o desenho. Entraram na fase do realismo visual e se
preocupam muito com a adequação de seu desenho à realidade; com isso, vão
desaparecendo as capacidades expressivas que têm os desenhos das crianças
menores.

Este instrumento de pesquisa não foi utilizado nas primeiras entrevistas de famílias com crianças. Foi inserido como recurso de apoio após a pesquisadora detectar, numa entrevista, que as crianças (uma de 6 e outra de 9 anos) não compreendiam uma das questões a elas dirigidas. Uma vez constatado que o desenho foi mais eficaz sobre a referida questão, os agrupamentos com crianças que já haviam sido entrevistados foram contatados novamente e todos aceitaram complementar a entrevista.

Enquanto desenhavam, as falas espontâneas das crianças e as intervenções da pesquisadora com perguntas de esclarecimento sobre o que estava sendo representado foram registradas em diário de campo. Mais do que uma resposta a uma questão, os desenhos motivaram um momento a mais de investigação com as crianças, uma pequena entrevista dentro da entrevista planejada. A partir do registro da fala delas no diário de campo, associada ao desenho solicitado, a pesquisadora pôde compreender a referência da memória representada, facilitando a checagem sobre a qualidade da informação expressa no desenho. Isto permitiu identificar o que era imaginação, fantasia ou associação a fatores externos e o que estava relacionado diretamente ao programa educativo vivenciado no Museu. Esta experiência da pesquisa fez jus às orientações metodológicas de Delval (2002, p.96) para utilização de desenho como técnica de apoio em entrevista com crianças:

Com todas as suas vantagens, o problema é que às vezes fica difícil interpretar os desenhos. Então, o melhor é complementar o desenho com a entrevista. Se primeiro fazemos a entrevista e depois pedimos o desenho, pode ocorrer que este reflita sobretudo os temas que surgiram na entrevista e limite a expressão do sujeito. É por essa razão que se recomenda, em muitos casos, fazer primeiro o desenho e depois perguntar sobre ele. Naturalmente, essa não é uma norma geral, mas depende do estudo que estamos empreendendo e dos objetivos que temos em vista. 
Respeitando aspectos éticos de pesquisa, a cada família ou adulto entrevistado foi enviada a transcrição para que manifestassem concordância. As manifestação de discordância foram discutidas e consideradas, tendo o depoente o direito de se sentir representado satisfatoriamente pelo instrumento de pesquisa utilizado. O feedback aos entrevistados permitiu, também, contribuir com as famílias, pois os sujeitos envolvidos puderam ter ciência, ou, quem sabe ainda, consciência, dos valores de educação que vivenciaram e compartilharam. Solicitou-se, quando do envio da entrevista transcrita, reflexões (que o participante pôde optar por responder ou não) a partir de questões como: "Para você, foi importante ler esta entrevista? Por quê? Há algum aspecto de suas relações sociais e familiares (com filhos, amigos, pais, outros) não percebido que a entrevista lhe fez notar? Gostaria de fazer algum outro comentário sobre esta experiência até este momento?”.

Como retribuição simbólica, por sua participação na pesquisa, cada agrupamento familiar recebeu um CD com as imagens digitais de sua participação no Interar-te (exceto imagens de atividades desenvolvidas no espaço expositivo do Museu). Todas as imagens são de autoria da própria pesquisadora (em respeito às leis dos diretos autorais), que as realizou por ser educadora na instituição do programa em estudo. Após a conclusão da pesquisa receberão uma versão digitalizada da dissertação. 


\section{RESULTADOS E DISCUSSÃO DOS DADOS COLETADOS}

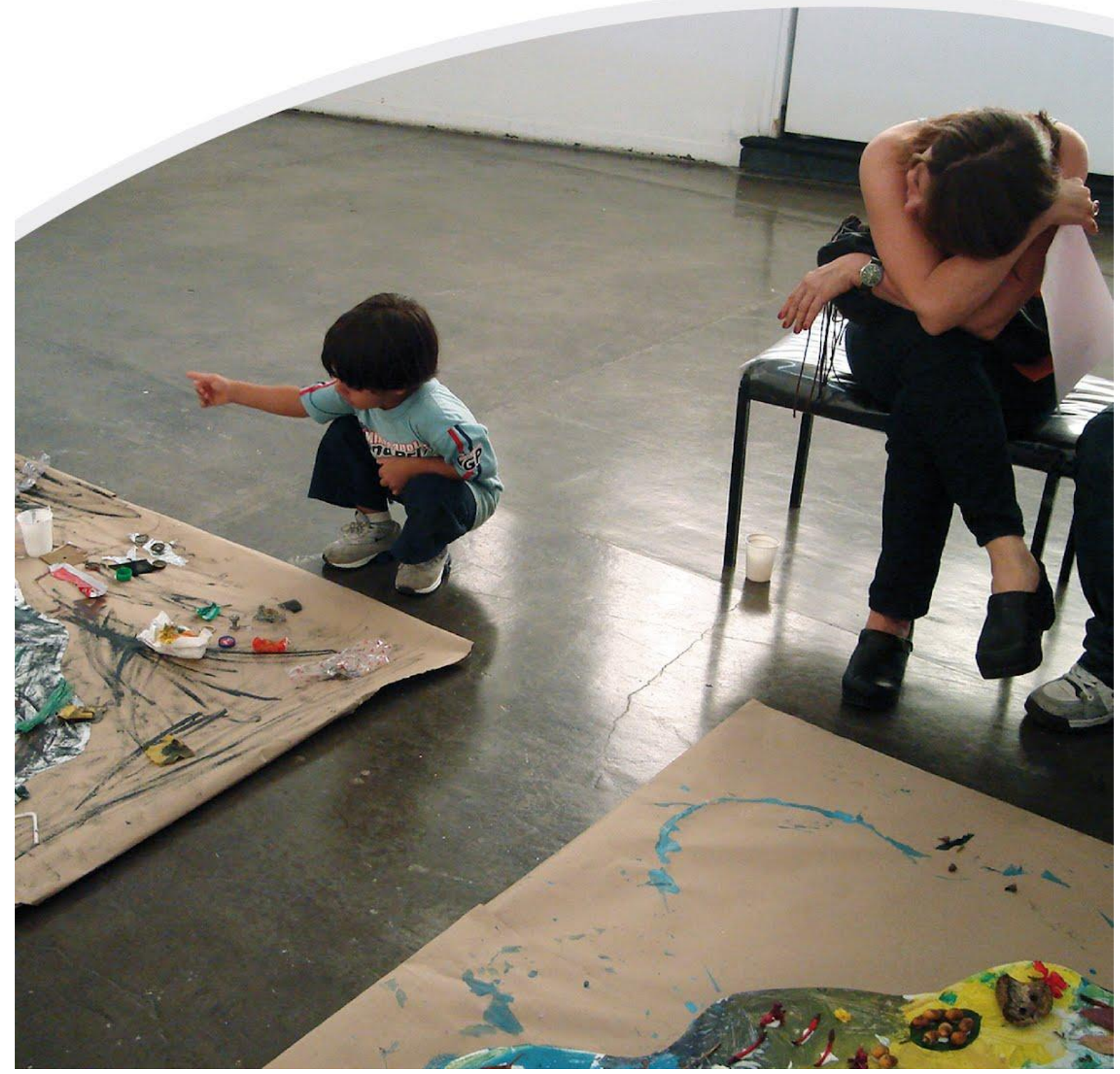

Figura 15 - Criança de 4 anos explica o trabalho coletivo aos participantes em oficina especial do Interar-te conduzida pela artista Renata Barros (também na imagem), na exposição Poéticas da Natureza, em agosto de 2008. 


\section{RESULTADOS E DISCUSSÃO DOS DADOS COLETADOS}

\subsection{Constituição da amostra}

Delimitado o programa educativo para estudo de caso, realizou-se um levantamento nos registros de participação das famílias no Interar-te no período selecionado (43 meses, entre outubro de 2006 e abril de 2010) para identificar os participantes que retornaram ao menos uma vez ao programa. No período indicado ocorreram 41 sessões do Interar-te, com 33 programações diferentes. No início algumas propostas foram oferecidas em diversos horários para o levantamento das preferências do público-alvo. Definiu-se, então, que as sessões ocorreriam onze meses por ano de janeiro a novembro, um sábado a cada mês.

Das 103 famílias presentes nas 33 programações diferentes oferecidas no período delimitado para estudo, 18 participaram do Interar-te mais de uma vez e formaram os agrupamentos selecionados como amostra da pesquisa.

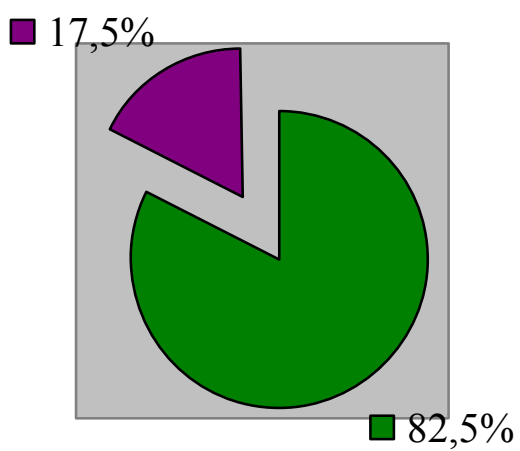

uma vez (85)

mais de uma vez (18) (amostra)

Gráfico 1: Participação das 103 famílias no período estudado.

O contato com os adultos dos 18 agrupamentos familiares selecionados para a pesquisa foi feito pelo envio de mensagens eletrônicas, por ser este o meio de comunicação usual na divulgação de novas sessões do programa para famílias que já frequentaram o Interar-te. 


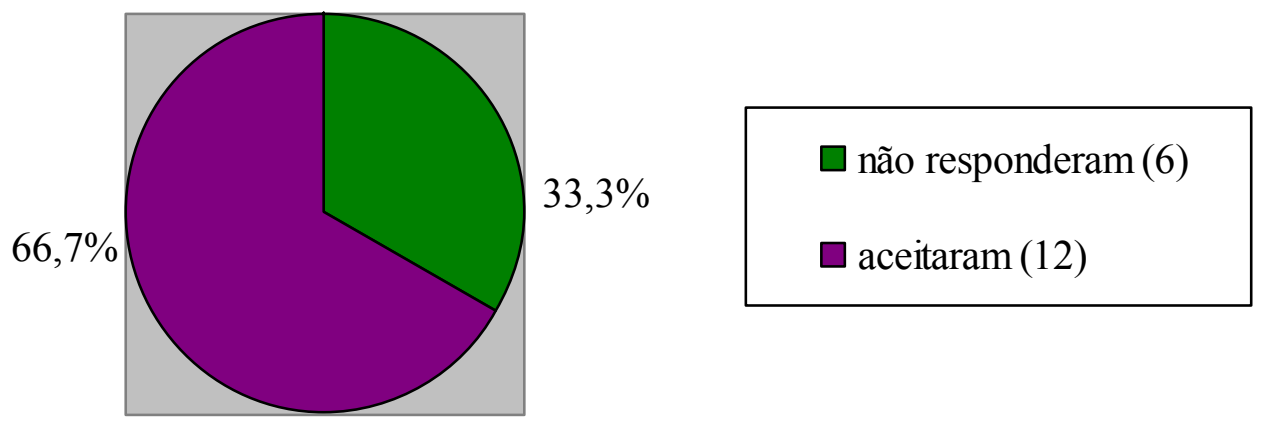

Gráfico 2: Famílias convidadas para a pesquisa (amostra).

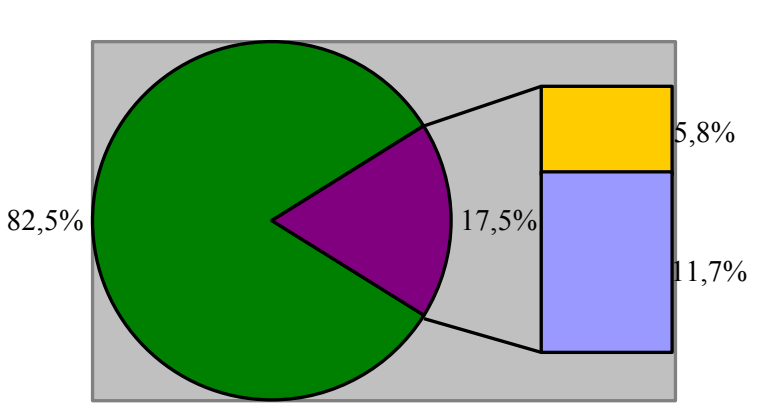

$\square$ participaram uma vez (85)

$\square$ retornaram (18) - amostra

$\square$ não responderam (6)

$\square$ entrevistadas (12)

Gráfico 3: Famílias entrevistadas diante do total que participou do Programa Interar-te.

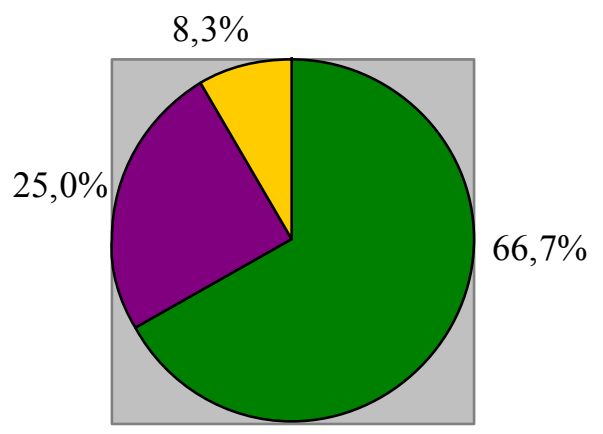
$\square 2$ vezes $(8)$
$\square 3$ vezes (3)
$\square 4$ vezes ou mais (1)

Gráfico 4: Número de vezes que cada família entrevistada participou do Interar-te no período estudado. 


\subsection{Qualificação das famílias}

Dos 12 agrupamentos familiares entrevistados obteve-se depoimento de:

- 13 adultos;

- 9 crianças com idade entre 5 e 11 anos;

- 6 jovens com idade entre 13 e 20 anos.

Diante destes dados, observa-se que 17 crianças e jovens participaram mais de uma vez do Interar-te no período estudado. Destes, 15 foram entrevistados. Entre os adolescentes, alguns já estavam com idade entre 18 e 20 anos à época da entrevista.

A idade mínima indicada para a participação no Interar-te é 5 anos. As crianças que na entrevista estavam com esta idade tinham entre 2 e 4 anos quando participaram do programa na condição de acompanhantes dos mais velhos ${ }^{41}$. Todas estas crianças entrevistadas com 5 anos participaram de sessões nas quais cumpriram a proposta feita para as famílias. Seus depoimentos e os desenhos de apoio versaram sobre as estratégias e os conteúdos programados.

Das 12 famílias entrevistadas em, apenas uma houve dois adultos como respondentes, pai e mãe das crianças frequentadoras do Interar-te. Esse dado tem importância em alguns cálculos de porcentagem da pesquisa: em questões genéricas foram considerados 12 adultos como amostra total (100\%), enquanto que em questões que demandaram respostas individuais foram considerados 13 . O índice utilizado será apontado nos gráficos e quadros.

No quadro abaixo, em que se apresentam características dos entrevistados, para efeito da identificação das famílias os agrupamentos foram numerados por ordem cronológica de realização das entrevistas.

\footnotetext{
${ }^{41}$ As crianças com menos de 5 anos participam da programação do Interar-te se a atividade proposta for pertinente à sua compreensão. Quando isto não é possível, dedicam-se a outras atividades, fora das programadas.
} 


\begin{tabular}{|l|l|l|l|}
\hline & $\begin{array}{l}\text { Adulto (s) / vínculo com } \\
\text { crianças e adolescentes }\end{array}$ & Criança (s) & Jovem (s) \\
\hline Família 1 & Amiga & Sexo feminino, 11 anos & Não há \\
\hline Família 2 & Mãe & $\begin{array}{l}\text { Sexo feminino, 20 anos } \\
\text { Sexo masculino, } 18 \text { anos }\end{array}$ \\
\hline Família 3 & Mãe & $\begin{array}{l}\text { Sexo feminino, 5 anos; } \\
\text { Sexo feminino, 9 anos }\end{array}$ & Não há \\
\hline Família 4 & Pai & $\begin{array}{l}\text { Sexo masculino, 5 anos; } \\
\text { Sexo masculino, } 8 \text { anos }\end{array}$ & Não há \\
\hline Família 5 & Mãe & $\begin{array}{l}\text { Sexo masculino, 6 anos; } \\
\text { Sexo feminino, } 8 \text { anos }\end{array}$ & Não há \\
\hline Família 6 & Tia & Não há & Sexo feminino, 17 anos \\
\hline Família 7 & Mãe & Não há & Sexo feminino, 13 anos \\
\hline Família 8 & Tia & Não há & $\begin{array}{l}\text { Sexo feminino, 13 anos (não } \\
\text { entrevistada) }\end{array}$ \\
\hline Família 9 & Pai & Não há & Sexo feminino, 16 anos \\
\hline Família 10 & Mãe & Sexo masculino, 6 anos & Não há \\
\hline Família 11 & Mãe & Não há & Sexo feminino, 13 anos \\
\hline Família 12 & Pai e mãe & $\begin{array}{l}\text { Sexo feminino, 7 anos; } \\
\text { (não entrevistado) }\end{array}$ & Não há \\
\hline
\end{tabular}

Quadro 1: Qualificação (no âmbito da pesquisa) das famílias entrevistadas.

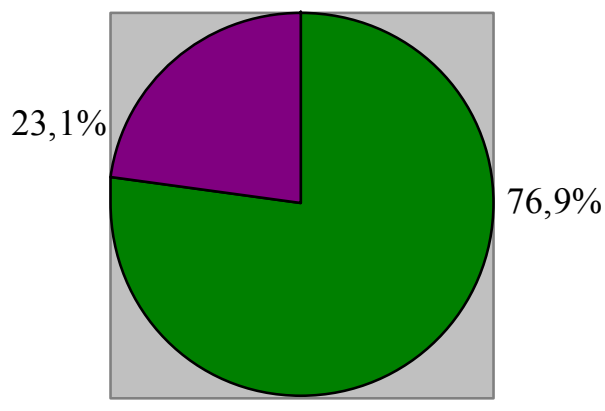

feminino (10)

masculino (3)

Gráfico 5: Gênero dos 13 adultos entrevistados.

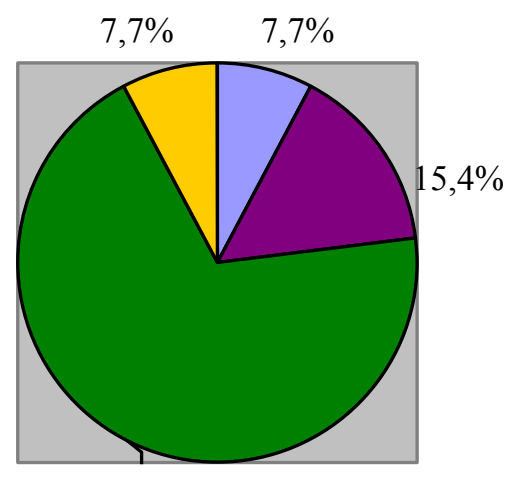

$\square 26-35$ anos (1)

36-45 anos (2)

46-55 anos (9)

$69,2 \%$

$\square 56$ ou mais (1)

Gráfico 6: Idade dos 13 adultos entrevistados 
Nos gráficos 7 e 8, abaixo, o gênero das crianças e jovens, incluindo os 2 não entrevistados:

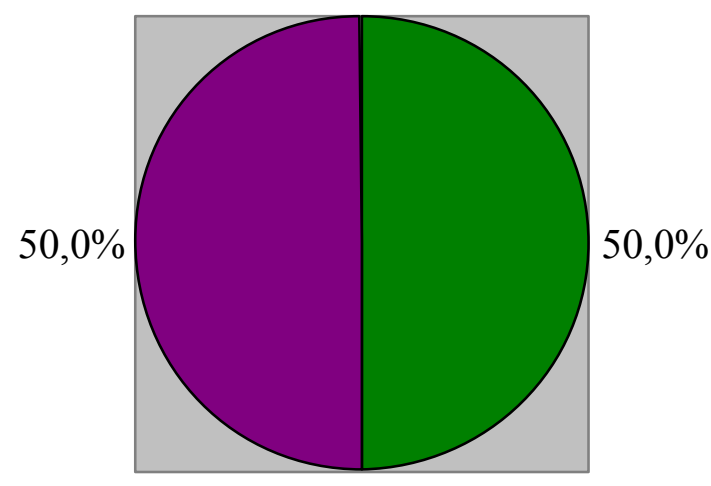

$\square$ feminino (5)

$\square$ masculino (5)

Gráfico 7: Gênero das 10 crianças (5 a 12 anos - idade por ocasião da entrevista)

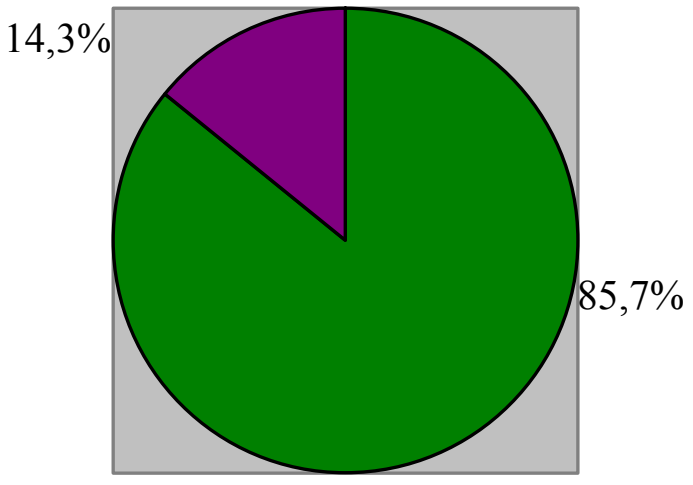

$\square$ feminino (6)

$\square$ masculino (1)

Gráfico 8: Gênero dos 7 jovens (13 a 21 anos - idade por ocasião da entrevista)

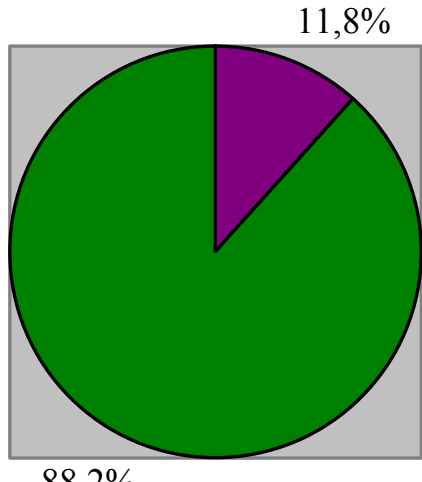

$88,2 \%$ $\square$ rede pública (2)

$\square$ rede particular (15)

Gráfico 9: Rede de ensino das escolas de educação básica onde estudam ou estudaram as 17 crianças e jovens 


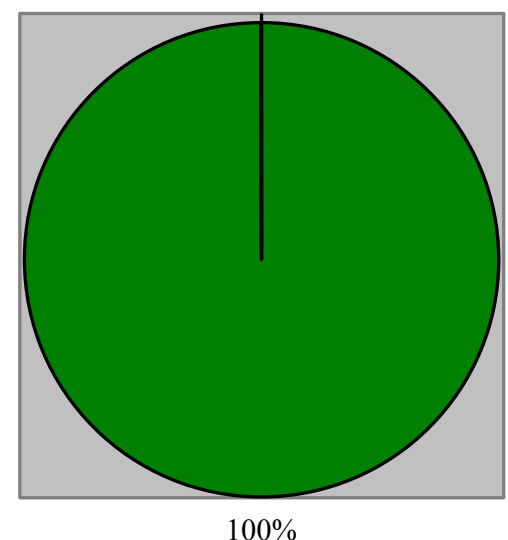

$\square$ ensino superior (13)

educação básica (0)

Gráfico 10: Nível de escolaridade dos 13 adultos entrevistados

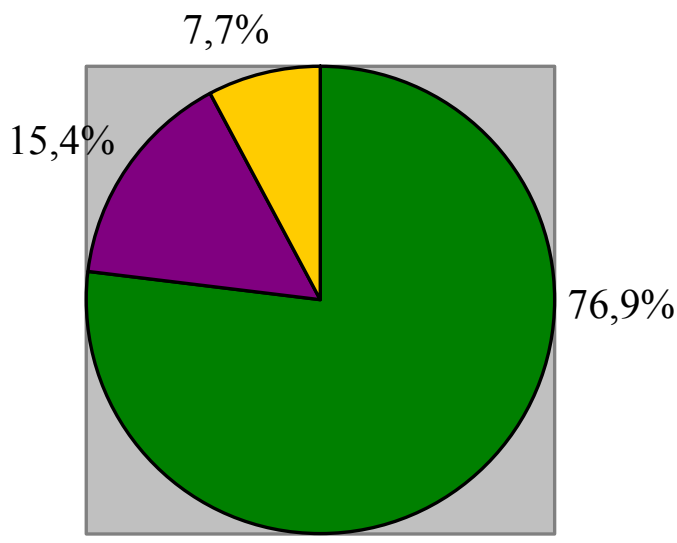

$\square$ pai ou mãe (10)

$\square$ tia (2)

$\square$ amiga (1)

Gráfico 11: Tipo de vínculo dos 13 adultos com as crianças e adolescentes

Entre os 13 adultos participantes do Interar-te, os 3 do sexo masculino são pais das crianças e jovens que acompanhavam, enquanto que, entre os 10 do sexo feminino, 7 são mães, 2 são tias e 1 é amiga da família.

A seguir a classificação econômica dos 12 agrupamentos segundo o Índice de Classificação Econômica Brasil da Associação Brasileira de Empresas de Pesquisa (ABEP) (Apêndice 2), elaborado com base no censo de 2009. Este instrumento classifica as famílias em: A1, A2, B1, B2, C1, C2, D e E.

A amostra constituiu-se apenas pelas classes A (75\%) e B (25\%). 


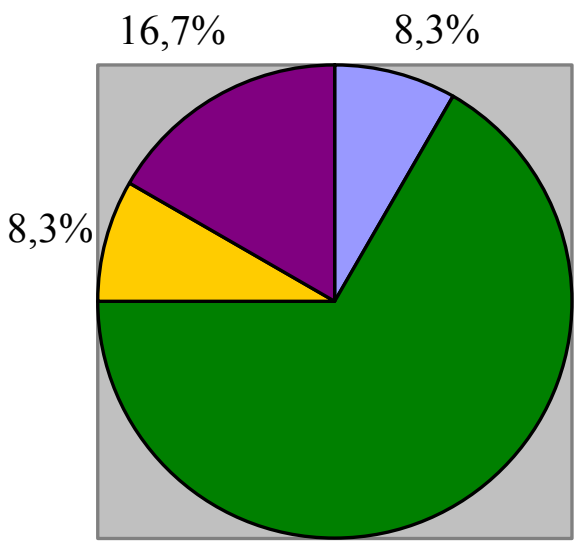

A1 (1)

A2 (8)

$\square \mathrm{B} 1(1)$

B2 (2)

$66,7 \%$

Gráfico 12: Classificação econômica dos adultos dos 12 agrupamentos familiares

A seguir apresentamos informações sobre o local de moradia das famílias em relação à localização do Museu e o meio de transporte utilizado para o percurso.

Abaixo, a distância entre o bairro onde residiam dos entrevistados adultos entre 2006 e 2010 e o MAC USP no Ibirapuera. O cálculo de distância aproximada entre os bairros e o Museu foi feito com base nos parâmetros dos mapas do sítio Google (<www.google.com.br〉, acesso em 27/09/2011), opção de rota para carro, uma vez que 11 dos 12 agrupamentos utilizaram este meio de locomoção para chegar ao Museu, considerando o endereço do Museu (Av. Pedro Álvares Cabral, s/nº, São Paulo-SP) e os bairros indicados.

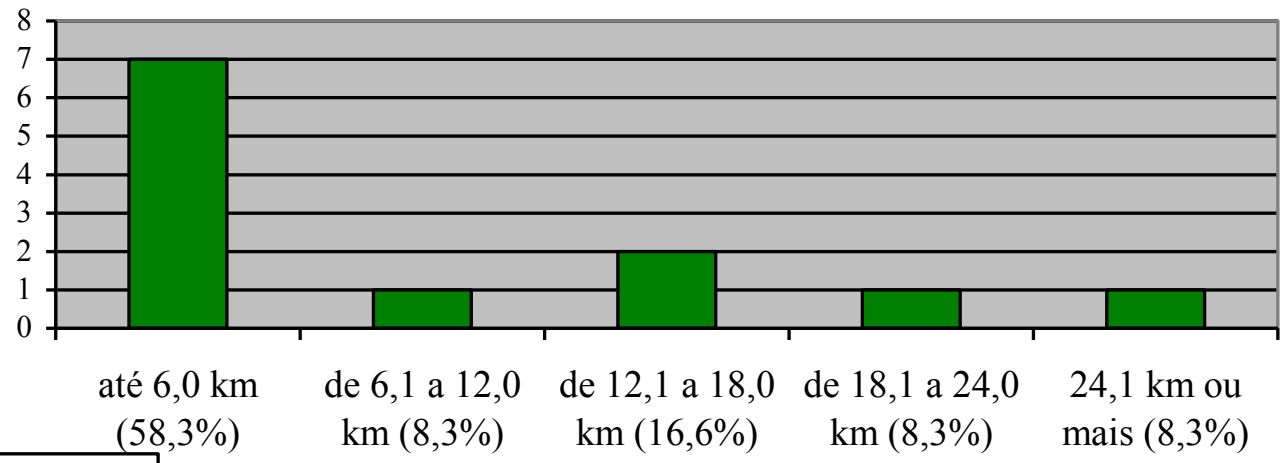

número de famílias

Gráfico 13: Distância em quilômetros entre o bairro em que moram ou moravam os adultos das 12 famílias. 


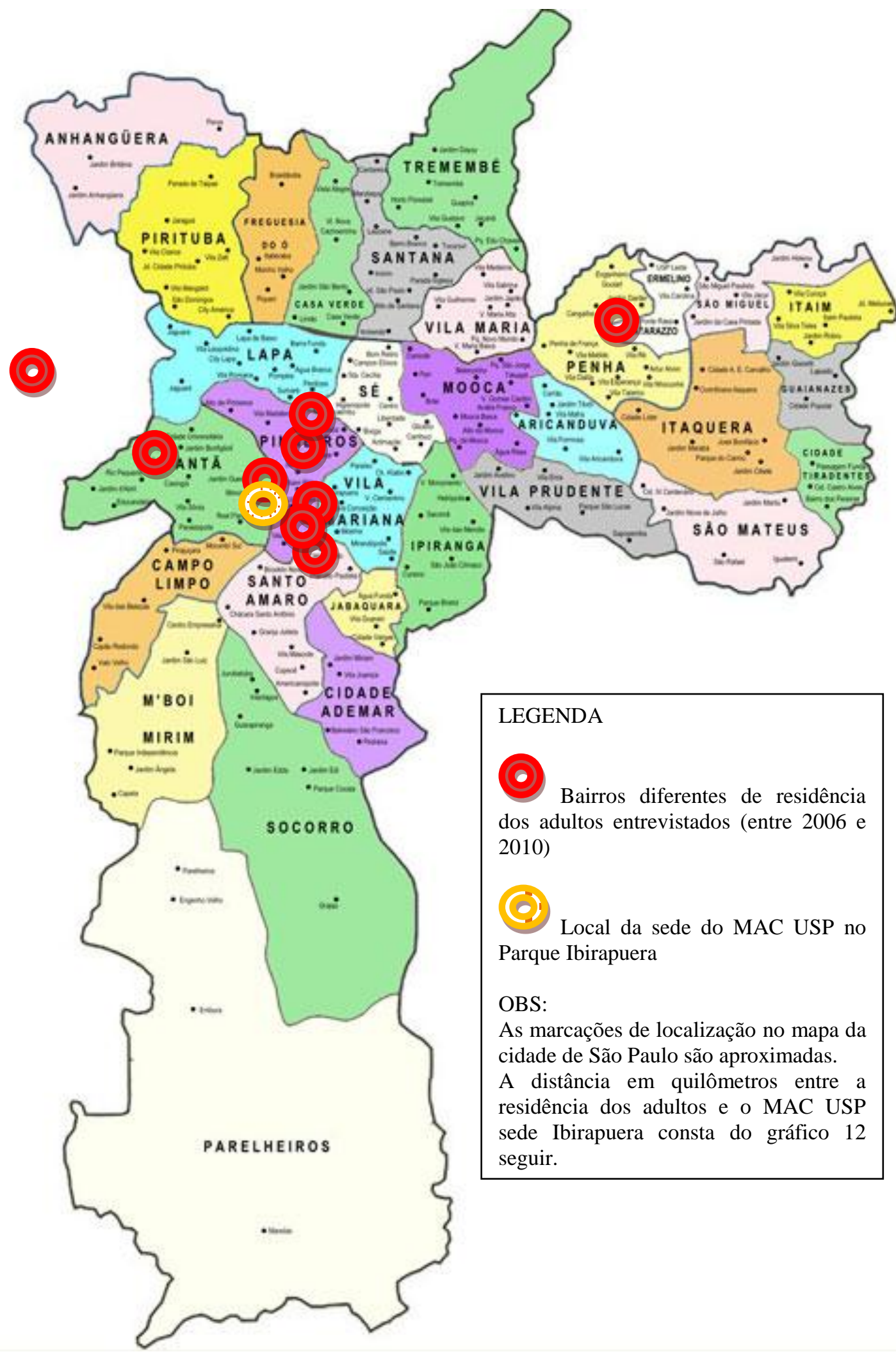

Figura 16: Mapa da cidade de São Paulo ${ }^{42}$ indicando o bairro de residência dos entrevistados adultos na época da participação no programa educativo Interar-te.

\footnotetext{
${ }^{42}$ Fonte: <http://www.sp-turismo.com/bairros-sp.htm>. Acesso em 27/09/2011.
} 


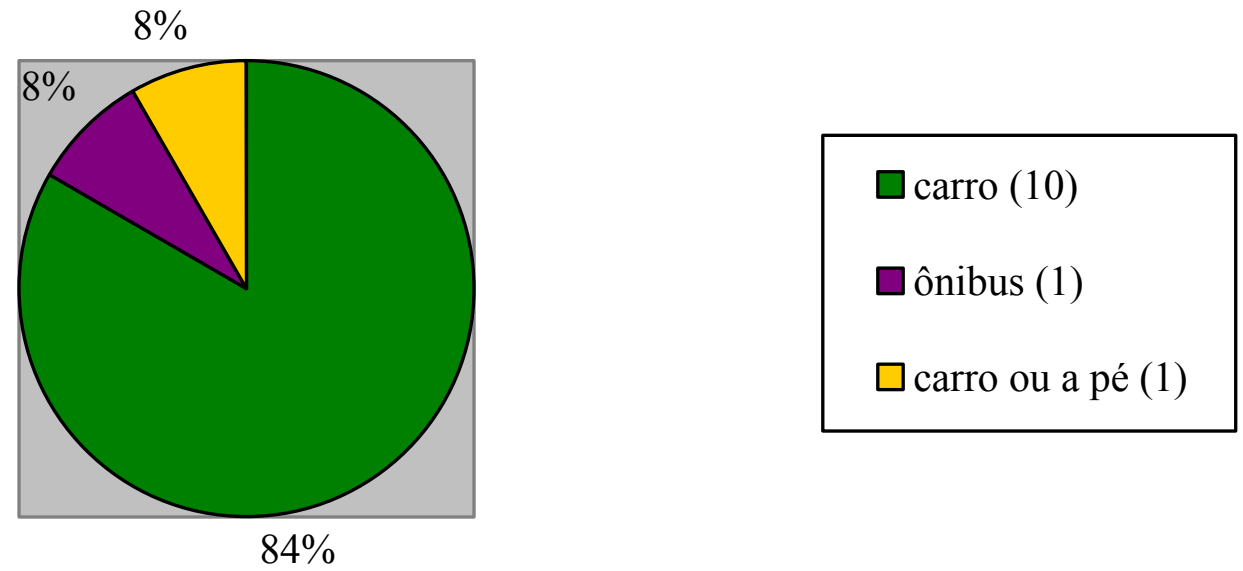

Gráfico 14: Meio de transporte utilizado pelas 12 famílias para irem ao MAC USP no Parque Ibirapuera.

A família que reside mais distante foi a que mais vezes (sete) participou do programa no período estudado (Gráfico 4, p.68) e a única que utilizou transporte público.

\subsection{Análise do corpus da pesquisa}

Diante do problema da pesquisa e das questões levantadas nos capítulos teóricos, apontamos os eixos centrais deste trabalho:

1. Qual a origem do contato dos adultos dos agrupamentos familiares com a arte?

2. Os adultos dos agrupamentos familiares estão proporcionando conhecimento em artes visuais e a formação de hábito de frequentação a exposições de arte às crianças e jovens?

3. O programa Interar-te do MAC USP contribui na promoção do conhecimento sobre artes visuais e incentiva a formação de hábitos de frequentação a instituições culturais?

Estas três questões centrais foram distribuídas nos instrumentos de investigação e na coleta de dados junto às famílias, ou seja, nas entrevistas semiestruturadas com adultos, crianças e jovens. Reiteramos que com as crianças até 12 anos foram utilizados desenhos como estratégia de apoio.

Os dados coletados nas entrevistas foram reorganizados na estrutura de questões do quadro abaixo. 


\section{Origem do contato dos adultos dos agrupamentos familiares com a arte. (investigação dirigida aos adultos)}

1.1. Quais eram suas atividades de lazer na infância e na adolescência?

1.2. Como a arte entrou em sua vida? Como foi a experiência com arte na infância e na adolescência, na escola e fora dela? Qual foi a participação de seus pais? Mais alguém cumpriu esse papel? Quem e como? Quem você considera que influenciou o seu gosto por arte?

1.3. Na sua opinião, o que desenvolve o gosto pela cultura?

\section{Verificação sobre se os adultos dos agrupamentos familiares estão favorecendo} conhecimento em artes visuais e formação de hábito de frequentação a exposições de arte às crianças e jovens.

(investigação dirigida ao grupo - ocasionalmente será indicado se alguma questão foi dirigida especificamente a adultos, jovens ou crianças. adultos, crianças e jovens)

2.1. Quais são as atividades de lazer dos adultos na atualidade? Quem acompanha os adultos em sua programação de lazer?

2.2. Quais são as atividades de lazer da família?

2.3. Quais os procedimentos da família em relação às atividades de lazer? Quem acompanha as crianças e jovens nessas atividades é sempre alguém da família de origem? Quem as escolhe? Qual o critério de escolha da atividade? Onde consultam a programação das atividades que frequentam?

2.4. A família tem o hábito de visitar exposições de arte? Qual a frequência de visita a exposições de arte? A família possui o hábito de frequentar exposições de arte ao viajar? A família tem conhecimento da existência de alguma instituição cultural (museu, ateliê de artista, outros) próxima de sua residência, em seu bairro? Já a visitaram? Os adultos visitam exposições de arte sozinhos, sem as crianças e adolescentes? Qual exposição mais marcou os adultos? Qual exposição mais marcou as crianças e jovens? Quantas vezes as crianças ou adolescentes visitam exposições de arte em um ano com a escola e com a família?

2.5. Aos adultos entrevistados que são os pais dos participantes do Interar-te: quando a escola dos filhos realiza atividade cultural extraclasse, o que acham? Incentivam? Buscam saber onde é a atividade? Conversam com as crianças ou adolescentes sobre esta experiência depois?

2.6. Aos adultos entrevistados que são os pais dos participantes do Interar-te: compram livros sobre arte e literatura, apresentam músicas e filmes aos filhos? Acompanham os que os filhos conhecem, mesmo que não seja na íntegra?

2.7. Qual é o ponto de vista das crianças e dos jovens? Dentre as atividades abaixo, quais preferem fazer com seus pais ou com acompanhantes adultos? Por quê?

a. Assistir um filme; ir ao cinema;

b. ouvir música; ir a shows;

c. ir a exposições;

d. outros.

2.8. Qual é o ponto de vista das crianças e dos jovens? Já foram a exposições de arte com a escola? É igual ou diferente das visitas com os pais ou outros adultos? Por quê? 


\section{Verificação se o programa Interar-te do MAC USP contribui na promoção do conhecimento sobre artes visuais e incentiva a formação de hábitos de frequentação a instituições culturais. \\ (investigação dirigida ao grupo - ocasionalmente será indicado se alguma questão foi dirigida especificamente a adultos, jovens ou crianças)}

3.1. Por que o adulto optou por proporcionar a experiência do programa Interar-te aos seus filhos ou a outras crianças ou adolescentes?

3.2. Como ficaram sabendo do Intera-te ao participarem pela primeira vez? Quem teve a ideia de participar?

3.3. Como foi para todos os entrevistados participar do Interar-te?

3.4. Por que voltaram a participar do Interar-te? Por que não participaram mais vezes? Indicaram o programa ou voltaram com amigos? Se a atividade fosse paga teriam participado?

3.5. O que vocês não sabiam sobre arte e passaram a saber depois de participarem do Interarte? Ocorreu algum outro tipo de conhecimento novo que gostariam de relatar?

3.6. O que fizeram no dia em que participaram do Interar-te, antes e depois da atividade?

Quadro 2: Perguntas feitas às famílias diante das 3 questões centrais da pesquisa a serem investigadas

Diante dessas questões, apresentamos a seguir os dados coletados.

PERGUNTA 1.1. QUAIS ERAM AS ATIVIDADES DE LAZER DOS ADULTOS NA INFÂNCIA E ADOLESCÊNCIA?

\begin{tabular}{|c|c|c|c|c|c|c|c|c|c|c|c|c|c|}
\hline \multicolumn{2}{|c|}{ Atividades $\quad$ Familia } & 1 & 2 & 3 & 4 & 5 & 6 & 7 & 8 & 9 & 10 & 11 & 12 \\
\hline \multirow{2}{*}{$\begin{array}{l}\text { Realivadas na } \\
\text { residência }\end{array}$} & 1. Brincar & $X$ & & & & $X$ & & & $X$ & $X$ & $\mathrm{X}$ & & $\mathrm{X}$ \\
\hline & 2. Assistir TV & & & & & & & & & & & $X$ & $\mathrm{X}$ \\
\hline \multirow{15}{*}{$\begin{array}{l}\text { Realizadas em } \\
\text { locais externos à } \\
\text { residência, na } \\
\text { mesma cidade }\end{array}$} & 1. Ir ao circo & & & $\mathrm{X}$ & & & & & & & & & \\
\hline & 2. Ir ao zoológico & $\mathrm{X}$ & & & & & & & & & & & \\
\hline & $\begin{array}{l}\text { 3. Ir ao clube, parque ou } \\
\text { bosque }\end{array}$ & & & & $\mathrm{X}$ & & & $\mathrm{X}$ & $\mathrm{X}$ & & & & \\
\hline & 4. Andar de bicicleta & & & & & & & & & & & & $\mathrm{X}$ \\
\hline & 5. Ir ao baile & & $\mathrm{X}$ & & & & & & & & & & \\
\hline & 6. Ir ao shopping & & & & & & $\mathrm{X}$ & & & & & & \\
\hline & 7. Visitar parentes & $\mathrm{X}$ & $\mathrm{X}$ & & & & & & & & & & $\mathrm{X}$ \\
\hline & $\begin{array}{l}\text { 8. Ir a feiras de } \\
\text { artesanato/arte popular }\end{array}$ & & & $\mathrm{X}$ & & & & & & & & & \\
\hline & 9. Ir ao cinema & $\mathrm{X}$ & $\mathrm{X}$ & & $\mathrm{X}$ & $\mathrm{X}$ & $\mathrm{X}$ & $\mathrm{X}$ & $\mathrm{X}$ & & & & \\
\hline & 10. Ir ao teatro & & $\mathrm{X}$ & & & & $\mathrm{X}$ & & & & & & \\
\hline & 11. Ir a espetáculo de dança & & & $\mathrm{X}$ & & & & & & & & & \\
\hline & 12. Ir à biblioteca & & & & & & $\mathrm{X}$ & & & & & & \\
\hline & $\begin{array}{l}\text { 13. Visitar exposições; ir ao } \\
\text { museu }\end{array}$ & & & & & & $\mathrm{X}$ & $\mathrm{X}$ & & & & & \\
\hline & $\begin{array}{l}\text { 14. Frequentar cursos de } \\
\text { atividades esportivas }\end{array}$ & & & & & & $\mathrm{X}$ & & & & & & \\
\hline & $\begin{array}{l}\text { 15. Frequentar cursos de } \\
\text { línguas estrangeiras }\end{array}$ & & & & & & $\mathrm{X}$ & & & & & & \\
\hline \multirow{3}{*}{$\begin{array}{l}\text { Realizadas em } \\
\text { outras cidades } \\
\text { (viagens) }\end{array}$} & 1. Ir à praia & $\mathrm{X}$ & & $\mathrm{X}$ & & & & $\mathrm{X}$ & & & & & $\mathrm{X}$ \\
\hline & 2. Ir à casa de familiares & & & $\mathrm{X}$ & & $\mathrm{X}$ & & & & & & & \\
\hline & 3. Turismo em geral & & & $\mathrm{X}$ & & & & $\mathrm{X}$ & & & & $\mathrm{X}$ & $\mathrm{X}$ \\
\hline \multirow{3}{*}{$\begin{array}{l}\text { Outras (sem } \\
\text { indicação do local } \\
\text { de realização) }\end{array}$} & 1. Ler & & & & & & $\mathrm{X}$ & & & & & & \\
\hline & 2. Ouvir música & & & & & & $\mathrm{X}$ & & $\mathrm{X}$ & & & & \\
\hline & 3. Escrever jornalzinho & & & & & & $\mathrm{X}$ & & & & & & \\
\hline
\end{tabular}

Quadro 3: Atividades de lazer dos 13 adultos na infância e adolescência - relatadas espontaneamente. 


\begin{tabular}{|c|c|c|}
\hline Atividades de lazer citadas nos depoimentos & $^{0}$ de vezes & $\% *$ \\
\hline \multicolumn{3}{|l|}{ Relacionadas à realização na residência: } \\
\hline 1. Brincar & 9 & 39,1 \\
\hline 2. Assistir TV & 3 & 13,0 \\
\hline \multicolumn{3}{|l|}{ Relacionadas a locais externos à residência, na mesma cidade: } \\
\hline 1. Ir ao circo & 1 & 4,3 \\
\hline 2. Ir ao zoológico & 1 & 4,3 \\
\hline 3. Ir ao cinema & 7 & 30,4 \\
\hline 4. Ir a exposições; ir ao museu & 2 & 8,7 \\
\hline 5. Ir ao teatro & 3 & 13,0 \\
\hline 6. Ir à biblioteca & 1 & 4,3 \\
\hline 7. Visitar parentes & 2 & 8,7 \\
\hline 8. Ir ao shopping & 1 & 4,3 \\
\hline 9. Ir ao clube, ao parque (municipal); ir ao bosque & 4 & 17,4 \\
\hline 10.Andar de bicicleta & 1 & 4,3 \\
\hline 11.Ir ao baile & 1 & 4,3 \\
\hline 12.Ir a espetáculo de dança & 1 & 4,3 \\
\hline 13.Ir a feiras de artesanato/arte popular & 1 & 4,3 \\
\hline 14.Frequentar cursos de atividades esportivas & 1 & 4,3 \\
\hline 15.Frequentar cursos de línguas estrangeiras & 1 & 4,3 \\
\hline \multicolumn{3}{|l|}{ Relacionados a outras cidades (viagens): } \\
\hline 1. Ir à praia & 4 & 17,4 \\
\hline 2. Ir à casa de familiares & 4 & 17,4 \\
\hline 3. Outras, visando conhecimento de novos lugares & 2 & 8,7 \\
\hline \multicolumn{3}{|l|}{ Outras: } \\
\hline 1. Ler & 1 & 4,3 \\
\hline 2. Ouvir música & 2 & 8,7 \\
\hline 3. Escrever jornalzinho & 1 & 4,3 \\
\hline
\end{tabular}

Quadro 4: Atividades de lazer dos 13 adultos na infância e na adolescência, por categoria (local de realização).

* Porcentagem calculada a partir do número (23) de atividades de lazer comentadas pelos entrevistados.

Entre as 23 atividades diferentes citadas pelos 13 entrevistados, a mais recorrente é o brincar $(39,1 \%)$. Nove entre 13 adultos $(69,2 \%)$ relatou isso. Brincava-se, geralmente, com familiares (irmãos, primos) ou vizinhos. Ir ao cinema aparece em segundo lugar (corresponde a $30,4 \%$ das atividades) e foi citado por $46,1 \%$ dos entrevistados. Ir a exposições e museus constou de dois relatos, ou seja, 15,4\% dos adultos entrevistados, e isso representa $8,7 \%$ das atividades indicadas nos depoimentos.

Podemos verificar nos quadros acima a diversidade de tipos de lazer presente nas práticas infanto-juvenis dos adultos da amostra da pesquisa, inclusive a presença do "ócio produtivo" - os itens 14 e 15 das atividades externas à residência, mas na própria cidade de moradia. 


\section{PERGUNTA 1.2. COMO A ARTE ENTROU NA VIDA DOS ADULTOS?}

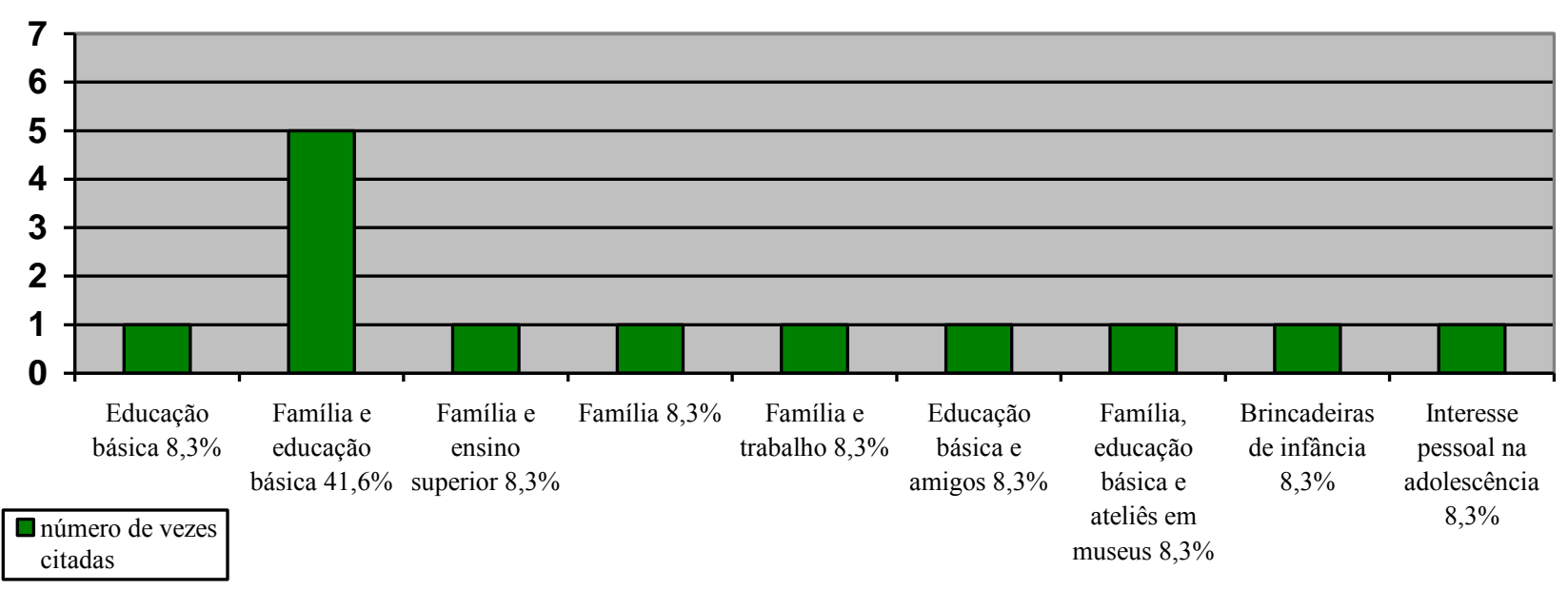

Gráfico 15: Formas de contato inicial com a arte em geral, indicadas pelos 13 adultos, por modalidade.

Como se pode observar no gráfico acima, parte dos 13 adultos entrevistados relataram mais de uma modalidade. A partir das indicações trazidas pelos adultos sobre as formas do seu contato inicial com as artes em geral, organizamos o quadro abaixo, no qual separamos cada tipo de contato indicado em três modalidades: educação formal, não formal e informal. Este dado interessa à pesquisa para podermos observar em que modalidade ocorreu a maior incidência da origem do contato destes adultos com as artes: família (educação informal), escola (educação formal) ou em ações promovidas por instituições culturais (educação não formal).

\begin{tabular}{|l|c|c|}
\hline Formas do primeiro contato dos adultos com a arte em geral & \multirow{2}{*}{ - de vezes citada } & $\% *$ \\
\hline Educação formal (educação básica) & 8 & 61,5 \\
\hline Educação informal (família) & 8 & 61,5 \\
\hline Educação não formal (museus) & 1 & 7,7 \\
\hline Outros & 2 & 15,4 \\
\hline
\end{tabular}

Quadro 5: Primeiro contato dos adultos com a arte em geral, por modalidade.

* Porcentagem calculada a partir do número de adultos entrevistados: 13. Observa-se que alguns apontaram mais de uma modalidade.

Os dados apresentados acima indicam que a maioria dos adultos $(61,5 \%)$ teve sua iniciação às artes tanto devido à influência e iniciativa de suas famílias quanto da escola (educação básica).

Os 8 entrevistados $(61,5 \%)$ que destacaram a família como responsável na iniciação do contato com as artes foram questionados sobre quem eram os familiares protagonistas nesta iniciação. O gráfico abaixo demonstra as respostas obtidas: 


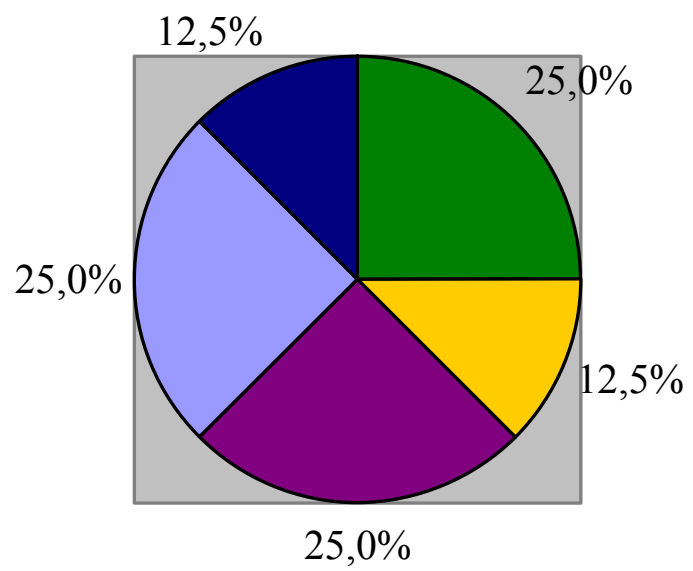
$\square$ irmãos mais velhos (2) $\square$ pai (1)
mãe (2)
$\square$ pai e mãe (2)
irmãos mais velhos e pai (1)

Gráfico 16: Grau de parentesco dos familiares responsáveis pelo primeiro contato com a arte.

Estes dados nos permitem afirmar que a família de origem $^{43}$ exerceu influência significativa nos hábitos culturais dos adultos entrevistados. Este levantamento refere-se ao contato inicial com as artes, mas sabe-se que a formação de hábitos culturais artísticos está relacionada à continuidade do contato e da frequência e, certamente, outras pessoas estão implicadas.

Os 8 adultos (61,5\% dos entrevistados) que se referiram à influência da escola em sua iniciação à frequentação de atividades artístico-culturais destacaram aulas de literatura e idas ao teatro. Apenas $2(15,4 \%)$ citaram o contato com as artes visuais. Estes dois entrevistados comentaram que tiveram aulas de História da Arte na escola. Um deles (família 6) disse: "Eu tinha arte na escola, eu estudei no [cita o colégio particular] e eu tinha história da arte na escola, eu lembro disso". Outro adulto apontou:

Foi na época que eu tava no Científico, que hoje é o ensino médio, né, porque em casa a gente nunca teve muito incentivo pra cultura - só música, porque minha mãe era pianista. Essa parte musical sempre foi muito desenvolvida em casa. E leitura, literatura também sempre foi muito desenvolvida. Artes Plásticas nunca foi uma coisa que eu tivesse muito contato. Aí quando eu tinha uns quinze anos, quatorze pra quinze anos, eu entrei no que era... na época lá... o que é equivalente ao ensino médio de hoje: eu tive uma professora de história que foi magnífica e que nos incentivou pra olhar esse lado de arte. E aí eu comecei a olhar e quis fazer um curso. Fiz um curso no MASP, na época, com aquele cara... como é que ele chamava?... Ele é crítico de arte e dava um curso de arte sempre... Jacob Klintowitz, fiz aula com ele, era o máximo... foi muito legal, fiz aula de História da Arte com ele, e aí que eu comecei a olhar mesmo pra essa coisa da arte, comecei a visitar museus... enfim, foi assim que entrou, através do estímulo de uma professora. (família 12)

Apenas um dos entrevistados apontou a visita a museus em atividades extraclasse. Outros relataram que nas aulas de Educação Artística não se apresentava arte como

\footnotetext{
${ }^{43}$ Pais e irmãos de uma pessoa; em geral, refere-se à família nuclear original de um adulto. (NICHOLS \& SCHWARTZ, 1998, p.486)
} 


\section{conhecimento, com conteúdos específicos da produção social e histórica da arte; praticavam}

atividades artesanais que visavam à confecção de produtos:

Adulta: (...) nas aulas de arte, arte chamava... artes industriais... era assim que chamava, né? Então, a gente fazia trabalhinho manual, assim, de serrinha, modelagem, alguma coisa, mas eu nunca fui boa nisso.

Pesquisadora: E você chegou a ver alguma obra de algum artista? O que você comentava, dessas análises que vocês faziam da literatura, da poesia, por exemplo, até dos trabalhos de vocês, ou de outros autores? Você falou que lia Machado de Assis, lia outros autores brasileiros... Isso acontecia em relação à arte visual, isso é, da pintura, da escultura, do desenho... vocês chegaram a produzir desenho, a discutir desenhos, pinturas, essas esculturas? Adulta: Não, não... acho que não. Desenhar... eu sempre fui péssima, muito, nem na escola eu não... não, a gente não teve incentivo disso aí. Eu lembro de modelagem, tipo com solda, essas coisas... mas, na minha época, não. Eu lembro já que... na... [cita a escola da filha], eles já faziam... a professora... ela vai te falar, ela punha uma cópia de uma Tarsila do Amaral, e eles copiavam, então.. e eu não, eu nunca tive, o professor nunca apresentou um pintor pra gente. Nunca...nunca tive essa... (família 2)

Adulta: Nossa, a minha escola... nossa, eu sou do tempo em que o ensino era muito rígido, olha... vou resgatar aqui... muito tempo atrás... mas no meu primeiro ano eu tinha uma professora chamada Mercedes, era o primeiro grupo escolar [cita o nome da escola], a professora carimbava todo o início de estudo de uma nova palavra, de uma nova letra, ela carimbava... Então, um pato, um pato pra ela... começava o P, aí você repetia PPP, o P naquela linha dividida ao meio, você dividia o tamanho da letra, gente do céu! E eu já gostava de colorir muito essas letras, o alfabeto, então eu já coloria. Isso eu lembro, já fazia um colorido que me agradava. Mas o desenho... olha aí, tinha aulas de puericultura, também podia pintar alguma coisa pra professora, a professora dava assim... mas normalmente desenhos mimeografados de puericultura... imagine, eu tive aula de puericultura! (risos), depois as gregas [desenhos de frisas gregas], que era uma coisa que me agradava fazer também, que ficavam muito bem feitas né, bem acabadas, eu pintava... essa coisa de explorar o lápis de cor, não era deixar só uma tonalidade clara, uma hora pôr muita força no lápis e criar aquela, aquela cor forte... assim, desaparecia o papel em baixo, ficava só uma massa do lápis. Na escola... a arte era o desenho geométrico, as gregas e... eu lembro uma vez de ter feito, de ter participado de concurso - o que era uma coisa terrível... participar de concurso de arte! Eu lembro de fazer um desenho que não era o desenho que eu gostaria de ter feito, eu lembro de mim, crítica com meu desenho, aquele momento que você fala: eu não sei desenhar. Então, eu lembro desse momento assim... e de participar de concurso, que era uma coisa que chegava na escola, você tinha que fazer um desenho pra participar de um concurso, aquelas coisas que você não sabe de onde chegou aquilo, qual era o objetivo... e era uma frustração só né, porque concurso, como diz bem aquela Fanny Abramovich, concurso é o fim: você privilegia uma pessoa em detrimento de não sei quantas, né, eu acho muito terrível a ideia de concurso. E eu lembro daquele concurso na minha infância como uma coisa muito ruim, frustrante. (família 8) 


\section{PERGUNTA 1.3 NA OPINIÃo DOS ADULTOS, O QUE DESENVOLVE O GOSTO PELA CULTURA?}

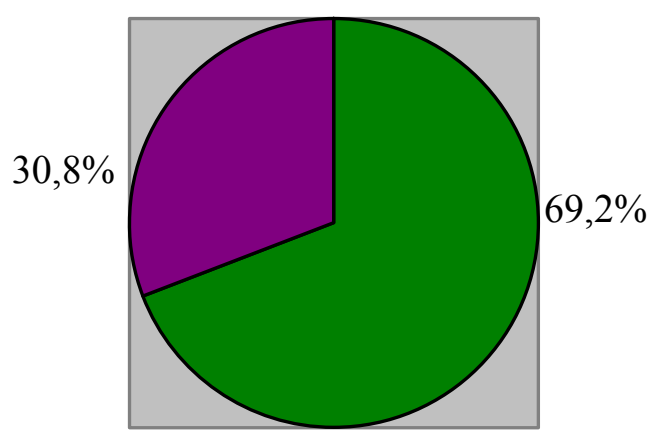

$\square$ frequentação estimulada pela família (9)

contato/frequência de origem indefinida (4)

Gráfico 17: Indicação de fator que desenvolve o gosto pela cultura para os 13 adultos.

O hábito de frequentação de programas culturais é apontado em $100 \%$ das respostas dos adultos à questão sobre o que desenvolve o gosto pela cultura. No gráfico acima separamos aqueles que apontaram a família como a responsável pela formação desse hábito $(69,2 \%)$ dos que não o especificaram claramente $(30,8 \%)$.

Uma das entrevistadas destacou a importância da adequação da atividade cultural à faixa etária das crianças. Para ela, este é um fator determinante do interesse e da motivação delas e está diretamente relacionado ao desenvolvimento do gosto que podem vir a ter por atividades culturais nos momentos de lazer em família. Esta entrevistada ressaltou também o valor do lúdico nas propostas de trabalho para o público infantil:

Pesquisadora: Em sua opinião, o que desenvolve o gosto pela cultura?

Adulta: Eu acho que você apresentar a cultura pra criança, isso desenvolve... por isso que eu acho muito importante ele ir pra museu, teatro, até mesmo cinema. Tanto que ele [o filho] é o que mais participou, né, porque eu acho que é o que desenvolve, não tem outro meio. E de uma maneira lúdica, né, a criança não se estressa... porque ele é de se estressar rápido! Criança...

Pesquisadora: Você está trazendo uma questão: que o grau de atenção da criança não é muito longo. Você acha que as atividades do Interar-te foram adequadas?

Adulta: Sim, porque elas foram lúdicas, respeitavam o cansaço da criança e despertavam o interesse da criança... às vezes, quando a gente tava no espaço [expositivo] e eles ficavam dispersos, era a hora de vir pro ateliê...

Pesquisadora: E você acha que as estratégias, e o tempo delas, foram apropriados?

Adulta: Foi apropriado...

Pesquisadora: Porque vocês ficavam em cada oficina cerca de duas horas, a duas horas e meia. Ele ficou bem e interessado esse tempo todo, todas as 7 vezes em que participaram do Interar-te?

Adulta: Sim, porque era lúdico, ele não percebeu esse tempo todo. O [nome do filho de 6 anos à época da entrevista] é uma criança que não é muito de ficar... você percebeu, né, ele não se estressava muito... foi bom, ele gostou. (família 10) 
PERGUNTA 2.1 QUAIS SÃO AS ATIVIDADES DE LAZER DOS ADULTOS, NA ATUALIDADE?

\begin{tabular}{|c|c|c|c|c|c|c|c|c|c|c|c|c|c|}
\hline \multicolumn{2}{|l|}{ Atividades } & 1 & 2 & 3 & 4 & 5 & 6 & 7 & 8 & 9 & 10 & 11 & 12 \\
\hline \multirow{2}{*}{$\begin{array}{l}\text { Realizadas na } \\
\text { residência }\end{array}$} & 1. Cozinhar & & & & & & & $\mathrm{X}$ & & & & & \\
\hline & 2. Assistir TV & & & & & & & & & $\mathrm{X}$ & & & \\
\hline \multirow{13}{*}{$\begin{array}{l}\text { Realizadas em locais } \\
\text { externos à residência, } \\
\text { na mesma cidade }\end{array}$} & 1. Ir a restaurante & & $\mathrm{X}$ & & & & & & & & & & \\
\hline & 2. Praticar esportes & & & & & $\mathrm{X}$ & & & & $\mathrm{X}$ & & & \\
\hline & 3. Ir ao clube, parque ou bosque & $\mathrm{X}$ & & & & $\mathrm{X}$ & & $\mathrm{X}$ & & & $\mathrm{X}$ & & \\
\hline & 4. Ir ao shopping & $\mathrm{X}$ & & & & & & & & & & & \\
\hline & 5. Visitar parentes & & $\mathrm{X}$ & & & & & & & & & & \\
\hline & 6. Ir a espetáculos musicais & & & & $\mathrm{X}$ & & & & $\mathrm{X}$ & & & $\mathrm{X}$ & $\mathrm{X}$ \\
\hline & 7. Ir ao cinema & & $\mathrm{X}$ & $\mathrm{X}$ & $\mathrm{X}$ & $\mathrm{X}$ & $\mathrm{X}$ & $\mathrm{X}$ & $\mathrm{X}$ & $X$ & & $\mathrm{X}$ & $\mathrm{X}$ \\
\hline & 8. Ir ao teatro & & & & & & & $\mathrm{X}$ & & & $\mathrm{X}$ & $\mathrm{X}$ & \\
\hline & 9. Ir a festas populares & & & & & & & & & & & $\mathrm{X}$ & \\
\hline & 10. Ir à livraria & & & $\mathrm{X}$ & & & & & & & & & \\
\hline & 11. Visitar exposições; ir ao museu & & & $\mathrm{X}$ & $\mathrm{X}$ & $X$ & & & $\mathrm{X}$ & & $\mathrm{X}$ & $\mathrm{X}$ & $\mathrm{X}$ \\
\hline & $\begin{array}{l}\text { 12. Frequentar cursos de atividades } \\
\text { esportivas }\end{array}$ & & & & & $\mathrm{X}$ & & & & & & & \\
\hline & 13. Frequentar cursos de línguas & & & & & & $\mathrm{X}$ & & & & & & \\
\hline \multirow{2}{*}{$\begin{array}{l}\text { Realizadas em outras } \\
\text { cidades (viagens) }\end{array}$} & 1. Ir pescar & & & & $\mathrm{X}$ & & & & & & & & \\
\hline & 2. Turismo em geral & $\mathrm{X}$ & & & & & & & & & & & \\
\hline \multirow{2}{*}{$\begin{array}{l}\text { Outras (sem indicação } \\
\text { do local de realivação) }\end{array}$} & 1. Ler & & & & & & & & & $\mathrm{X}$ & & & \\
\hline & 2. Ouvir música & & & & $\mathrm{X}$ & & & & & & & & \\
\hline
\end{tabular}

Quadro 6: Atividades de lazer dos 13 adultos na atualidade - relatadas espontaneamente.

\begin{tabular}{|l|c|c|}
\hline \multicolumn{1}{|c|}{ Atividades de lazer citadas nos depoimentos } & No de vezes & $\% *$ \\
\hline Relacionadas à realização na residência: & & \\
\hline 1. Cozinhar & 1 & 5,3 \\
\hline 2. Assistir TV & 1 & 5,3 \\
\hline Relacionadas a locais externos à residência, na mesma cidade: & 1 & 5,3 \\
\hline 1. Ir a restaurante & 2 & 10,5 \\
\hline 2. Praticar esportes & 4 & 21,1 \\
\hline 3. Ir ao clube, parque ou bosque & 1 & 5,3 \\
\hline 4. Ir ao shopping & 1 & 5,3 \\
\hline 5. Visitar parentes & 4 & 21,1 \\
\hline 6. Ir a espetáculos musicais & 10 & 52,6 \\
\hline 7. Ir ao cinema & 3 & 15,8 \\
\hline 8. Ir ao teatro & 1 & 5,3 \\
\hline 9. Ir a festas populares & 1 & 5,3 \\
\hline 10. Ir à livraria & 7 & 36,9 \\
\hline 11. Visitar exposições; ir ao museu & 1 & 5,3 \\
\hline 12. Frequentar cursos de atividades esportivas & 1 & 5,3 \\
\hline 13. Frequentar cursos de línguas & & \\
\hline Relacionadas a outras cidades (viagens): & 1 & 5,3 \\
\hline 1. Ir pescar & 1 & 5,3 \\
\hline 2. Turismo em geral & 1 & \\
\hline Outras: & 1 & 5,3 \\
\hline 1. Ler & 1 & \\
\hline 2. Ouvir música & & \\
\hline Q & & 1 \\
\hline
\end{tabular}

Quadro 7: Atividades de lazer dos 13 adultos na atualidade, por categoria (local de realização)

* Porcentagem calculada a partir do número de adultos entrevistados: 13. Observa-se que alguns apontaram mais de uma atividade, totalizando 19 atividades (número correspondente a 100\%). 
No quadro acima pode-se verificar a diversidade de tipos de lazer, incluindo as de "ócio produtivo" (itens 12 e 13 das atividades externas à residência realizadas na própria cidade de moradia) e as atividades familiares no tempo de não trabalho, porém não representativas do "tempo livre", como cozinhar. Entre as 19 atividades citadas pelos entrevistados sobre suas práticas de lazer atuais, ir ao cinema é a mais recorrente $(52,6 \%)$. Dez dos 13 adultos (77\%) a citaram. Ir a exposições aparece em segundo lugar, com 36,9\% das citações. Foi mencionada por 7 dos 13 entrevistados (53,9\%).

Este índice é significativamente maior em relação às práticas de lazer dos mesmos entrevistados em sua infância e juventude (Quadro 4, p.78). Apenas 2 entrevistados $(15,4 \%)$ frequentavam exposições na infância e juventude, enquanto que 7 deles $(53,9 \%)$ relataram ter esta prática em seu lazer pessoal na vida adulta, nos momentos em que não há uma programação planejada para toda a família que abarque o interesse das diferentes faixas etárias. Sabe-se que este alto índice de frequentação a exposições como opção de lazer não é comum à população em geral e ressaltamos que esse hábito foi adquirido pelos adultos da amostra e incorporado às suas práticas de lazer.

Os dados coletados na Pergunta 1.2., sobre como a arte havia entrado na vida dos adultos (Quadro 5, p.79), foram retomados com finalidade comparativa. Com aquelas informações, sabemos que a arte (em geral, não unicamente as artes visuais) entrou na vida destes adultos, quando eram crianças e jovens, por influência predominante da família e da educação básica. Com a Pergunta 2.1. interessou-nos averiguar a forma inicial de frequentação a exposições com obras de arte pelos adultos.

Dos 13 depoimentos colhidos obtivemos informações que apontam diversificadas origens do hábito de visitação a exposições de arte - ou históricas nas quais obras de arte estivessem presentes.

No relato das adultas das famílias 3 e 11, verificamos a importância das vivências culturais e artísticas - em geral na infância e adolescência - para que o contato com exposições de arte em instituições culturais, na vida adulta, fosse incorporado nas práticas culturais das entrevistadas.

Pesquisadora: Como que a arte entrou na sua vida?

Adulta: Então,... arte digamos institucionalizada, de visitar a museus e tudo mais, com certeza foi na época da faculdade, da graduação,... na minha época, as escolas nunca visitavam muito museus, esse tipo de coisa eu não... a gente ia muito à peça de teatro e acho que assim, um pouco o gosto disso que foi introduzido... não intencionalmente, mas os meus pais trouxeram uma ideia de beleza que nos marcou, e eu percebo que eu e meus irmãos, nós estamos marcados por essa noção de beleza que eles nos deram. Por isso que eu digo não institucionalizada, não de trazer a museu, porque eu não me lembro disso, mas... Essa coisa aconteceu mais na graduação, mesmo, que aí eu comecei a entender o que era exposição, 
visitava exposição quase que diariamente, na época da faculdade. E foi assim, foi esse gosto que foi gerando assim um pouco pela música, às vezes até um pouco pela parte crítica da minha mãe, que tinha, que tem isso exacerbado. Isso foi entrando, aos pouquinhos mesmo, e foi gerando para nós uma maturidade, uma cultura, que a gente também carrega, por conta da própria origem da família, né, que é de uma cidade da Chapada Diamantina, uma cidade histórica, com monumentos tombados pelo patrimônio, que tem uma tradição religiosa muito forte. Então tudo isso sempre aconteceu na nossa vida, então desde pequena a gente vai lá, passava as férias todas lá. (família 3)

Pesquisadora: Como que a arte entrou na sua vida, como foi a sua experiência com a arte na infância, na adolescência, pensando na escola e fora dela, com a sua família?

Adulta: Eu diria que, na escola, a minha experiência foi um tanto formal, vamos dizer assim, de um âmbito acadêmico realmente de formação de um olhar daquilo que vem de uma forte marca do acadêmico, na concepção da criação artística. Quando eu, já jovem, comecei a me interessar cada vez mais, eu devo dizer assim - havia na minha família... meu pai era pintor, pintava a óleo, eu tenho uma tia ainda viva que ainda pinta, eu tenho uma prima que fez muito tempo ilustração prá publicações no país e, depois, se transformou em editora de arte, trabalhou muito com edição de arte no país e fora do país - então, havia uma possibilidade no ambiente familiar. Ela era concreta? Não exatamente, mas havia. Quando eu me vejo jovem, eu acho que foi o interesse pela literatura, e, depois da literatura, a descoberta do que podia me trazer é... como contribuição pra abrir o meu olhar... o ambiente... já na graduação em Artes. (família 10)

O incentivo à visitação de exposições de arte também se deu por professores da educação básica. Por exemplo, no caso da adulta da família 12 (depoimento citado à p.80, sobre como a arte havia entrado na vida dos adultos): o estímulo veio de uma professora de História do equivalente, hoje, ao ensino médio. Já para o seu companheiro, a trajetória transita na juventude entre o interesse por poesia e desenho e, na vida adulta, às oportunidades de viagens em sua rotina de trabalho. No depoimento dele é notória a importância da frequentação a museus de arte à sua formação cultural. À época da entrevista, além de continuar trabalhando na carreira profissional iniciada pelo curso de graduação em Administração, dedicava-se às artes visuais com afinco, como artista:

Adulto: Bom, a minha história é assim, de família, nada,.. nenhuma relação. Em algum momento eu comecei a me interessar muito por poesia. Aí, eu escrevia algumas coisas e eu não sei como passei pro desenho. Aí eu fiquei no desenho. Eu já pintava, já desenhava e... até que no final do colegial [atual ensino médio] eu me inscrevi num curso de desenho mesmo, e aí aquilo abriu todo um horizonte pra mim. Eu terminei esse curso de desenho começando minha primeira pintura, mas aí eu entrei na faculdade, entrei em Administração na GV e optei por essa carreira profissional. Mas foi interessante porque, na minha carreira, eu viajava muito pro exterior e aí eu tive a oportunidade de ter muito contato com arte porque eu ia atrás, eu queria ver museu... e aquilo foi acumulando, foi acumulando, acumulando e vira e mexe eu tentava voltar: comecei um curso de pintura, mas eu viajava tanto que era difícil manter essa... esse trabalho paralelo. Mas ele sempre ficou lá, latente, até que, depois, eu resolvi assumir mais isso, mas eu resolvi fazer o mestrado mesmo que foi uma forma de retomar essa parte artística. Mas eu fiquei 20 anos trabalhando em marketing sem um desenvolvimento artístico; eu costumava falar que eu era um artista bissexto, né, produzia assim, de vez em quando, alguma coisa. Então foi essa... a minha história é muito de acumular muita informação, e ter esses caminhos. Você tinha falado de uma exposição importante, talvez a exposição mais importante da minha vida tenha sido uma que eu vi no MASP, que chamava Ernst, Magritte, Miró, era uma apresentação dos surrealistas e foi a partir do surrealismo que eu passei do desenho (que eu tinha um desenho surrealista) pra pintura, que eu fui pro abstracionismo. Então eu fiz todo um caminho a partir dessa... e todo o meu mestrado, ele centrou, depois ele ficou todo explicado por uma pintura do Magritte que é aquela que tá ali na entrada da porta, lá do lado de 
fora, que é O Império da Luz. Porque O Império da Luz explica toda a questão do claro-escuro que tá em todo o meu trabalho. Então aí eu consegui perceber que, naquela exposição, eu consegui... quer dizer, o Magritte me pegou - e ali, a partir dali, eu pesquisei, eu colecionei livros do Magritte, eu fui entender a história dele. E a partir dali eu fiz todo um curso de arte próprio, a partir dessa curiosidade.

Pesquisadora: Como que você dosa a arte hoje, continuando a trabalhar em outra área? Você considera um hobby... é mais que um hobby... Como você nomearia essa relação e que peso isso tem na sua vida, hoje?

Adulto: Ah, hoje é mais importante, eu trouxe prum plano maior. Hoje eu faço muitas coisas, então a arte está um pouquinho mais equiparada com as outras coisas. Antigamente não, antigamente era o trabalho e o que dá mais pra fazer, né... tanto que até...

Adulta: E raramente dava prá fazer muita coisa...

Adulto: Tanto que até a constituição de família, essa coisa, veio muito tempo depois, porque eu era muito dedicado ao trabalho. Mas eu ia acumulando, como se eu ficasse acumulando esse tempo todo... eu fiquei acumulando informações, então eu tive oportunidade de conhecer museus fantásticos como o Hermitage, em Leningrado... São Petersburgo... e...fui a Paris... Bom, aí eu tive muito contato, morei nos Estados Unidos, conheci o Smithsonian inteiro... Gosto muito de arte contemporânea, então ia muito atrás de museus não tão conhecidos... fui pra Rússia, pra buscar os contemporâneos, aí fui atrás do Malevich, e aí... aí foi! Mas sempre num plano meio teórico, meio hobby mesmo, não tava nem produzindo muito. Depois é que eu fui retomar a produção. Como se tivesse deixado meio congelado e, depois, fosse pegar lá na frente. (família 12)

Os três depoimentos acima (famílias 3, 10 e 12) justificam a opção de não inserir, na entrevista semiestruturada, uma questão pontual sobre como os adultos haviam iniciado a frequentação a exposições de arte. Estimava-se que esta atividade era decorrente de vivências artísticas iniciadas em outras áreas, como artes cênicas, literatura, cinema e música. A questão era colocada pela pesquisadora, durante as entrevistas, quando o depoimento apontava a frequentação a exposições, o que não ocorreu com todos os entrevistados. O depoimento a seguir é outro exemplo desta estratégia de abordagem. Nele, a adulta trouxe a informação sobre a visita a museu histórico com a presença de obras de arte, embora ela não tenha comentado claramente ter visto obras de arte durante essa visita.

Pesquisadora: Quando você começou a frequentar museus de arte?

Adulta: Foi depois... Não, eu já tinha ido antes... Minha mãe já tinha levado a gente antes pra museu. Mas, a minha mãe, ela não tem estudo, então era um conhecimento bem, assim, bem superficial, a gente ia porque o museu era bonito, de repente. E aí chegava lá, tinha as histórias e a gente se encantava com as histórias. O primeiro museu que a minha mãe me levou foi o museu do Ipiranga, a gente vinha até conversando no carro, hoje. Então a minha mãe até adorou contar umas histórias, assim, do avô dela, do pai dela, de umas armas que tem lá... aí então a gente se interessava mais. Então a gente ia só por ir, porque ninguém tinha conhecimento em arte... a minha mãe levava sem... sem... como é que fala... sem conhecimento, a gente ia porque era bonito, mesmo o lugar. Ah, vamos num parque, aí chegava lá e tinha um museu, aí a gente ia.

Pesquisadora: Quando foi a primeira vez que você visitou uma exposição só de obras de arte? Adulta: Ai, meu Deus, acho que a primeira vez que eu visitei uma exposição de arte... eu não me lembro? Foi depois da Faculdade, assim, que eu fui visitar com o intuito de visitar uma exposição.

Pesquisadora: Mas e ir mesmo sem esse intuito que você fala de ir para conhecer, já que você estuda arte na faculdade, mas de repente entrar porque é um lugar bonito, também, mas em um lugar que tinha uma exposição só de obras arte, isso chegou a acontecer antes?

Adulta: Chegou a acontecer, foi na Pinacoteca.

Pesquisadora: Com quem você estava? 
Adulta: Eu estava com colegas, fui é... quer ver que exposição que foi... não lembro a exposição, mas eu fui numa exposição pra ver a exposição mesmo.

Pesquisadora: Esses colegas de onde eram?

Adulta: Da escola. Eu tava no terceiro... no segundo ano, do ensino médio. ${ }^{44}$ (família 10)

\section{O entrevistado da família 9 possui uma experiência diferente das apresentadas.}

Comentou que a leitura de revistas em quadrinhos na adolescência despertou seu interesse por conhecer museus de arte.

Pesquisadora: E em relação às artes visuais, a exposições de arte... Quando é que você se aproximou disso?

Adulto: Na escola, primeiro a gente se aproximou do teatro. As artes visuais, eu acho que me aproximei delas primeiro pelos livros, e por ouvir dizer, vendo nos livros, nos livros didáticos (ou mesmo em outros livros), outras obras, mas de ver a arte, arte visual, de me encantar, de visitar, só foi depois dos dezoitos anos. Eu não me lembro de ter acontecido antes.

(...)

Pesquisadora: Você falou que isso começou com você depois dos dezoitos anos, né. Teve a ver com sua área de estudo, teve a ver com alguém que te acompanhava, como é que isso ficou tão presente como é?

Adulto: Eu acredito mesmo que por influência dos gibis. Porque eu lia muitos gibis, eu acho que eu li todos os gibis da minha época, trocava gibi, amontoava gibi, era fanático por gibi, mas, principalmente os gibis da Disney, tinha o Almanaque do Tio Patinhas e sempre tinha uma história que tava ligada num museu ou uma obra... Monalisa... Acho que, se a gente for ver quantas vezes a Monalisa aparece no gibi, se a gente pesquisar isso, é uma grandeza sem tamanho. Então quando eu visitava... a pergunta é interessante, porque me faz recordar que eu conheci alguns artistas por meio dos gibis, acho que esse é meu principal caminho. (família 9)

Ressaltamos, dos depoimentos à Pergunta 2.1., quem acompanha espontaneamente os adultos em suas atividades de lazer no tempo livre. Este levantamento não é equivalente ao das atividades de lazer das famílias, ou seja, à programação escolhida para atender a todos (Pergunta 2.2, cuja análise encontra-se a seguir).

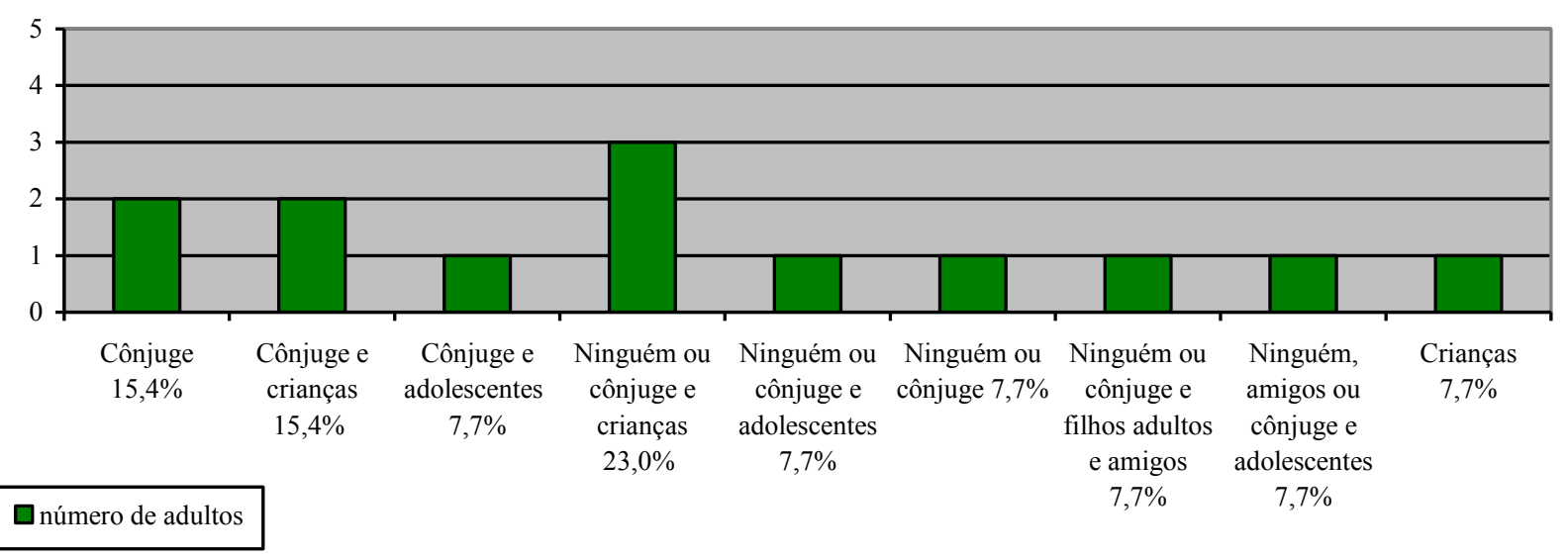

Gráfico 18: Acompanhante(s) dos entrevistados em seu lazer atual.

* Porcentagem calculada considerando o universo de 13 adultos entrevistados.

\footnotetext{
${ }^{44}$ Este depoimento demonstra que a elaboração das respostas não segue uma ordem cronológica. Conforme vão respondendo, a memória vai sendo ativada e os fatos comentados são retomados e revistos. Esta reelaboração ocorreu também com outros depoentes.
} 
Duas das mães entrevistadas priorizam acompanhar os filhos em programações infantis em seus momentos de lazer. Elas abrem mão de atividades para satisfação pessoal, ou, melhor, atrelam seu bem estar a estar em companhia dos filhos. Vejamos:

Pesquisadora: Quais são suas atividades de lazer? Quem te acompanha, quem escolhe?

Adulta: (risos)

Pesquisadora: Você tem lazer?

Adulta: O meu lazer atualmente tá sendo o deles, né, então é cinema infantil, é parquinho, tem sido bem assim mesmo. Meu, basicamente... ah... as exposições (risos).

Pesquisadora: Então, quem te acompanha?

Adulta: As crianças e o meu marido também, às vezes. (família 5)

Pesquisadora: Quais são suas atividades de lazer?

Adulta: Então, eu costumo muito sair com ele [refere-se ao filho de 6 anos] para museus, parque. É... mais assim, porque eu não gosto de ir em shopping, por exemplo, eu não gosto muito... mas ele vai com o pai pra cinema. Eu nunca levei ele pro cinema, agora eu levo ele pra teatro, também.

Pesquisadora: E você R. quais são suas atividades de lazer pessoais?

Adulta: Também são essas...

Pesquisadora: Quem te acompanha?

Adulta: Normalmente é o G [filho]... (risos) (família 10)

Poderíamos associar as práticas de lazer destas mães à falta de oportunidade delas para delegar o cuidado dos filhos para poderem realizar atividades livremente. No entanto, ambas são casadas e não demonstraram interesse em solicitar o apoio dos companheiros para saírem sem os filhos, sozinhas ou em companhia de amigos.

\section{PERGUNTA 2.2 QUAIS SÃO AS ATIVIDADES DE LAZER DAS FAMÍLIAS?}

\begin{tabular}{|c|c|c|c|c|c|c|c|c|c|c|c|c|c|}
\hline \multicolumn{2}{|l|}{ Atividades } & 1 & 2 & 3 & 4 & 5 & 6 & 7 & 8 & 9 & 10 & 11 & 12 \\
\hline \multirow{10}{*}{$\begin{array}{l}\text { Relacionadas a } \\
\text { locais externos à } \\
\text { residência, na } \\
\text { mesma cidade }\end{array}$} & 1. Ir a restaurante & & $\mathrm{X}$ & & & & & & & & & & \\
\hline & $\begin{array}{l}\text { 2. Praticar atividades esportivas (jogar } \\
\text { futebol, andar de bicicleta) }\end{array}$ & & & & & $\mathrm{X}$ & & & & & & & \\
\hline & 3. Ir ao clube, parque ou bosque & $\mathrm{X}$ & $\mathrm{X}$ & & $\mathrm{X}$ & $\mathrm{X}$ & & & & & $\mathrm{X}$ & & $\mathrm{X}$ \\
\hline & 4. Ir ao shopping & $\mathrm{X}$ & & & & & & & & & & & \\
\hline & 5. Visitar parentes & & $\mathrm{X}$ & & & & $\mathrm{X}$ & & & & & & \\
\hline & 6. Ir a espetáculos musicais & & & & & & & & $\mathrm{X}$ & & & $\mathrm{X}$ & $\mathrm{X}$ \\
\hline & 7. Ir ao cinema & & & $\mathrm{X}$ & $\mathrm{X}$ & $\mathrm{X}$ & $\mathrm{X}$ & & $\mathrm{X}$ & $\mathrm{X}$ & & $\mathrm{X}$ & $\mathrm{X}$ \\
\hline & 8. Ir ao teatro & & & & $\mathrm{X}$ & & & $\mathrm{X}$ & & & $\mathrm{X}$ & $\mathrm{X}$ & $\mathrm{X}$ \\
\hline & 9. Ir a festas populares & & & & & & & & & & & $\mathrm{X}$ & \\
\hline & 10. Visitar exposições; ir ao museu & & & $\mathrm{X}$ & $\mathrm{X}$ & $\mathrm{X}$ & $\mathrm{X}$ & $\mathrm{X}$ & $\mathrm{X}$ & & $\mathrm{X}$ & $\mathrm{X}$ & $\mathrm{X}$ \\
\hline \multirow{2}{*}{$\begin{array}{l}\text { Relacionadas a } \\
\text { outras cidades } \\
\text { (viagens) }\end{array}$} & $\begin{array}{l}\text { 1. Ir a propriedades rurais (sítio, } \\
\text { chácara) }\end{array}$ & & & & & $\mathrm{X}$ & & & & & & & \\
\hline & 2. $\quad$ Turismo em geral & $\mathrm{X}$ & & & & & & & & & & & $\mathrm{X}$ \\
\hline Outras & 1. Ouvir música & & & & $\mathrm{X}$ & & & & & & & & \\
\hline
\end{tabular}

Quadro 8: Atividades de lazer das 12 famílias na atualidade - relatadas espontaneamente. 


\begin{tabular}{|l|c|c|}
\hline Atividades de lazer citadas nos depoimentos & No de vezes & $\% *$ \\
\hline Relacionadas à realização na residência & 0 & 0 \\
\hline Relacionadas a locais externos à residência, na mesma cidade: & & \\
\hline 1. Ir a restaurante & 1 & 7,7 \\
\hline 2. Praticar atividades esportivas & 1 & 7,7 \\
\hline 3. Ir ao clube, parque ou bosque & 6 & 46,2 \\
\hline 4. Ir ao shopping & 1 & 7,7 \\
\hline 5. Visitar parentes & 2 & 15,4 \\
\hline 6. Ir a espetáculos musicais & 3 & 23,1 \\
\hline 7. Ir ao cinema & 8 & 61,5 \\
\hline 8. Ir ao teatro & 5 & 38,5 \\
\hline 9. Ir a festas populares & 1 & 7,7 \\
\hline 10. Ir a exposições; ir ao museu & 9 & 69,2 \\
\hline Relacionadas a outras cidades (viagens): & & \\
\hline 1. Ir a propriedades rurais (sítio, chácara) & 1 & 7,7 \\
\hline 2. Turismo em geral & 2 & 15,4 \\
\hline Outras: & & \\
\hline 1. Ouvir música & 1 & 7,7 \\
\hline
\end{tabular}

Quadro 9: Atividades de lazer das famílias na atualidade por categoria (local de realização).

* Porcentagem calculada considerando-se as 13 atividades (100\%) citadas pelos 13 adultos.

Entre as 13 atividades diferentes realizadas pelas famílias (adultos acompanhando crianças ou jovens), a mais recorrente é ir a exposições, tendo sido citada por 9 dos 13 $(69,2 \%)$ entrevistados. Ir ao cinema consta em segundo lugar, sendo citada por 8 dos 13 $(61,5 \%)$ entrevistados.

Para esta questão, não houve referência sobre atividades de lazer realizadas na residência, tais como brincar, assistir TV ou assistir filmes em DVD. Nota-se que quando as crianças e jovens foram questionadas sobre o que preferem fazer na companhia de familiares (Gráfico 31, p.103), obteve-se respostas sobre práticas de lazer realizadas pelas famílias na residência. Um exemplo é o depoimento dos dois filhos jovens da família 2, no qual se nota referência à companhia da mãe:

Pesquisadora: Dessas atividades abaixo, quais vocês preferem fazer com os pais de vocês? Assistir um filme, ir ao cinema; ouvir música, ir ao um show; ir a uma exposição ou alguma outra atividade?

Jovem do sexo feminino: Assistir um filme.

Pesquisadora: Com quem?

Jovem do sexo feminino: Com a minha mãe.

Pesquisadora: Por quê?

Jovem do sexo feminino: Porque ela sempre quer assistir filme comigo. [silêncio]

Pesquisadora: Quem escolhe esse filme?

Jovem do sexo feminino: Eu.

Pesquisadora: Vocês discutem depois?

Jovem do sexo feminino: Não, porque ela sempre tá dormindo! 


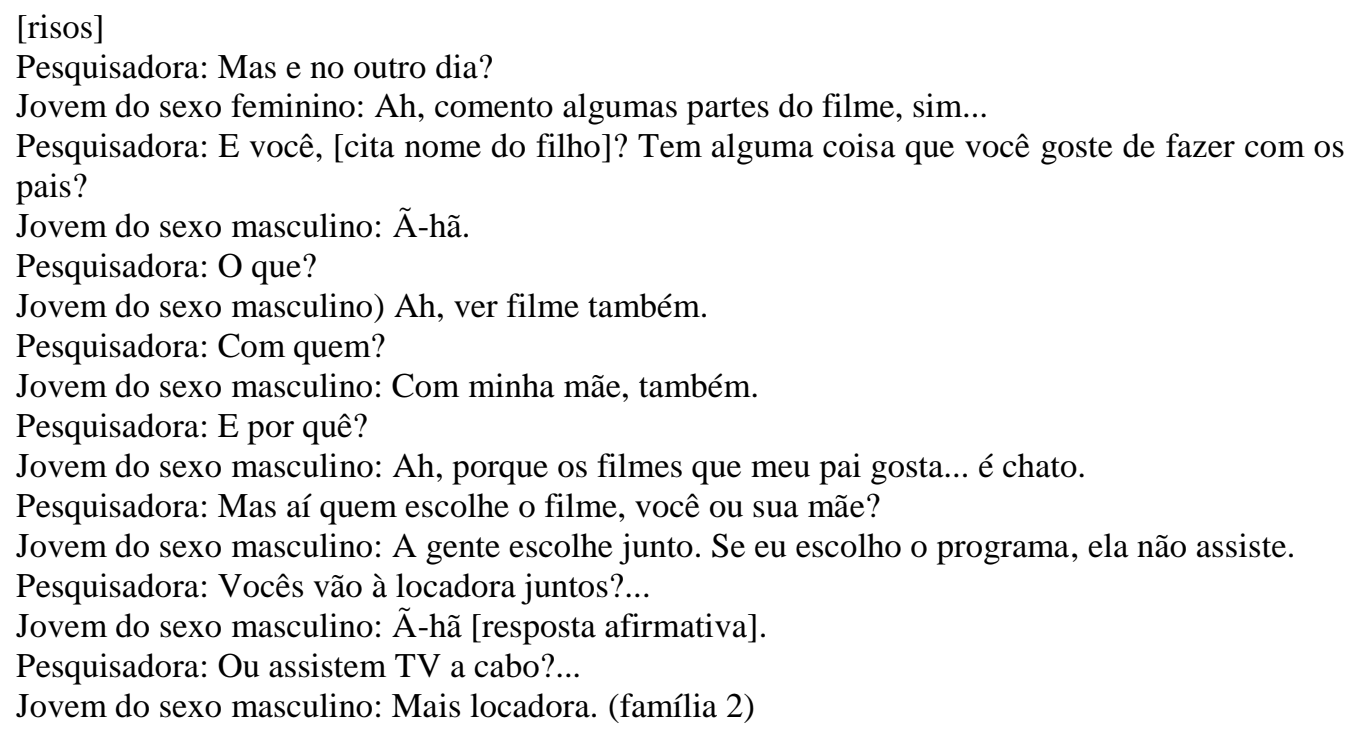

Da análise de questões anteriores sobre o lazer dos adultos entrevistados, obtivemos as informações: na infância e juventude (Quadro 4, p.78), ir ao cinema representava 30,4\% das atividades e ir a exposições 8,7\%. No lazer atual dos adultos (Quadro 7, p.83), ir ao cinema representa 52,6\% das práticas de lazer e ir a exposições 36,9\%. Porém, no lazer em família, ir a exposições $(69,2 \%)$ supera ir ao cinema $(61,5 \%)$. Em relação às atividades de lazer realizadas no tempo livre, individualmente ou por motivação pessoal, os adultos optam mais por frequentar exposições com a família.

Diante destes índices e dados já analisados na Pergunta 1.2 (pp.79-81), constatamos que, para os adultos da amostra, ir a exposições foi um hábito adquirido com as práticas de lazer artístico-culturais, em geral vivenciadas com a família de origem e com a escola (educação básica). O hábito de frequentação de exposições, uma vez adquirido, foi incorporado aos valores dos adultos sobre práticas a serem compartilhadas e estimuladas nas relações familiares atuais. Assim, buscam proporcionar esta vivência a crianças e jovens com os quais se relacionam. Falk e Dierking, em The Museum Experience (2011. p.43) comentam sobre o comportamento de famílias em exposições, embora no contexto de visitação a zoológicos nos Estados Unidos: “(...) that parents seemed to use their children to visit museums. The children's presence somehow sanctioned their visit, although it was often evident that parents were enjoying the social outing."

Sabe-se que, em uma grande cidade como São Paulo, nas duas últimas décadas, as instituições culturais que realizam exposições obtiveram maior visibilidade nos meios de comunicação de massa. Houve, também, aumento de patrocínio destinado aos setores educativos. Estas informações vão além do objeto de estudo desta pesquisa, mas podemos 
comentar que investimentos em educação e formação de público tornaram-se grandes atrativos para empresas que buscam atrelar sua imagem à de contribuintes para melhorias sociais.

De qualquer modo, constatamos com a pesquisa que ir a exposições corresponde, para a amostra estudada, um valor adquirido em relação à educação de seus filhos. $\mathrm{O}$ depoimento abaixo apresenta a insistência como fator de investimento dos adultos na educação dos filhos:

Adulta: O lazer que a gente tem em família, né, que você fala, os quatro? A gente vai, como ela
[filha de 6 anos] falou, à praça, parques... raramente andar de bicicleta no Villa-Lobos
[parque], uma coisa assim... a gente tenta incentivar essa parte artística indo ao museu, mas, às
vezes, eles não têm muita paciência, né, mas a gente ainda assim insiste um pouco. (família 12)

Para uma mãe, a motivação para a filha frequentar exposições é comparada ao consumo:

\footnotetext{
Adulta: Sim, valorizamos o que não é consumo, ou, se pensarmos que sim, poderíamos ensinar nossos filhos a consumir cultura, arte, não só bens de consumo. Então vejo como investimento. (família 7)
}

Em uma sociedade de estrutura econômica capitalista, esta comparação se justifica e faz compreender. No entanto, nos alerta para uma questão: há clareza e discernimento, por parte do público, então consumidor de produtos da indústria cultural, da diferença entre os produtos culturais que visam ao "consumismo" dos de qualidade artística e estética? Cabe-nos indagar, ciente de que esta pesquisa não fornecerá respostas, se estão educados para poder desfrutar da cultura artística em seu cotidiano, a partir de escolhas.

PERGUNTA 2.3. QUAIS OS PROCEDIMENTOS DAS FAMÍLIAS, EM RELAÇÃO ÀS ATIVIDADES DE LAZER:

\section{PERGUNTA 2.3.1. QUEM ACOMPANHA AS CRIANCAS E OS ADOLESCENTES?}

Para analisar esta questão, consideramos ser mais indicativo dos procedimentos de lazer das famílias observar quem os levou ao Interar-te (Gráfico 11, p.72) e apresentar alguns dos depoimentos colhidos.

Sabe-se que as crianças são dependentes dos pais; eles escolhem as atividades dos filhos (Gráfico 19, p.93) e, quando não os acompanham, fornecem condições para que participem, autorizando que familiares ou amigos próximos o façam.

Já os adolescentes são menos dependentes. Passam não só a optar mais pela programação, cedendo menos à vontade dos pais, como optam por não sair com estes, e, sim, com os amigos. Três mães de jovens relatam a diferença de comportamento dos filhos em relação aos interesses sobre as práticas de lazer em família. Vejamos: 
(pesquisadora) Quem que te acompanha nestas atividades?

(mãe) Ah, o L..

(pesquisadora) Seu marido?

(mãe) É.

(pesquisadora) Mas nos passeios, nos jantares, seus filhos nunca vão?

(mãe) Ultimamente, não. Ah, tipo uns dois anos prá cá eles não vão, eles não vão mais, eles iam muito nesses jantares, e a gente ia em família, (...) mas não, ultimamente, não, eles têm o lazer deles... não nos acompanham mais. (família 2)

Pesquisadora: Quais são suas atividades de lazer, M.?

Adulta: Cada vez menos... (risos). Meu lazer é cozinhar, que eu amo de paixão. Mas, em segundo lugar, eu adoro teatro. Semana passada eu fui ao teatro. E, assim, a gente vai ao museu, tem quinze dias a gente foi à Bienal, vamos ao parque...

Pesquisadora: Quem te acompanha?

Adulta: Então... antes a [cita nome da filha de 13 anos] nos acompanhava muito mais, hoje não mais. Por exemplo, há quinze dias atrás que a gente foi à Bienal ela não quis ir... ela quis ficar dormindo...

Adolescente: Eu tinha acabado de sair e ir a uma festa... eu tava com sono!

Adulta: O L. [esposo] me acompanha... Semana passada eu fui ao teatro sozinha.

(...)

Pesquisadora: E quem escolhe geralmente as atividades de lazer de vocês?

Mãe: Ah... depende. Às vezes o L., às vezes eu... mas hoje, na verdade, o lazer dela... ela só quer ir pra balada. Até então nós escolhíamos assim... o que a gente acha legal dela conhecer... é... sabe, essa coisa assim de criar uma oportunidade de ver uma coisa diferente, de fazer uma coisa diferente, né... de aprender a conhecer as coisas, né? Então hoje é complicado... Por exemplo, cinema ela só quer ir com os amigos. Hoje a gente queria ir ao cinema, ela vira e fala assim: ah... mas só tem coisa ruim no cinema... Essa semana ela foi ao cinema... então pai e mãe não rola...

Pesquisadora: Verdade A.? (risos)

Adolescente: É. (família 7)

Pesquisadora: Por que você voltou (ou não voltou) mais vezes a participar do programa?

Adulta: Eu acredito que eu voltei uma única vez e, depois, eu sinto muito não ter conseguido voltar outras vezes. Julgo que, por algumas situações, porque aí eu... uma delas muito específica: eu leciono aos sábados agora, então isso me causa um impedimento. Mas eu diria, assim: porque minha filha agora já é maior, porque esses finais de semana, de alguma maneira, ficam tomados - ou pelos estudos ou por uma atividade que ela já tem na sua própria história de vida (...). (família 11) 


\section{PERGUNTA 2.3.2. QUEM ESCOLHE AS ATIVIDADES?}

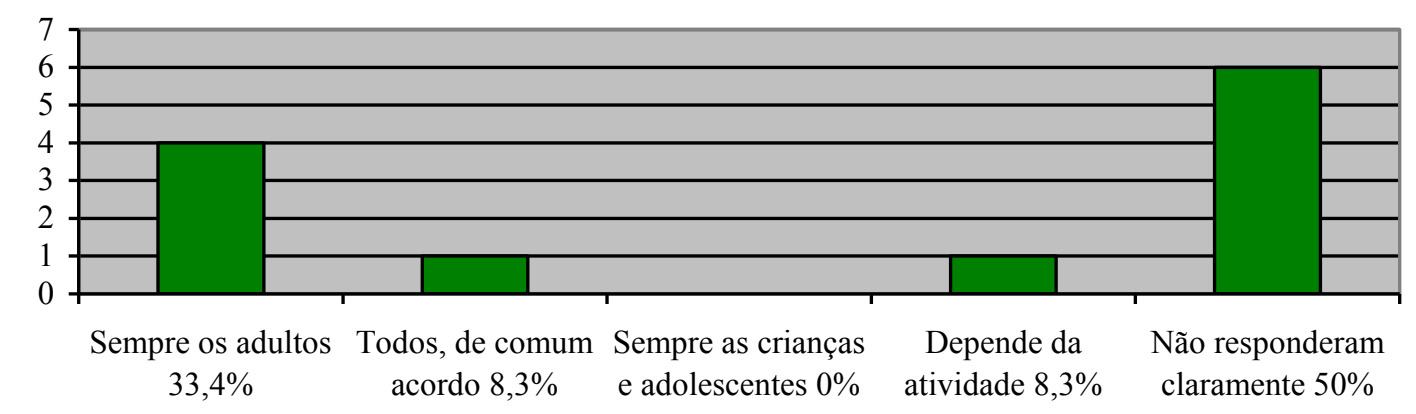

$\square$ número de famílias

Gráfico 19: Indicação sobre quem opta pelas atividades de lazer das famílias.

* Porcentagem calculada a partir do número de famílias entrevistadas: 12.

Para os pais entrevistados da família 12, embora haja discussão com as crianças para verificação do interesse de participação numa programação em família, certas atividades, como viagens, são determinadas por eles, enquanto outras são, por si, determinantes dos interesses - como o cinema infantil.

\section{PERGUNTA 2.3.3. QuAL O CRITÉRIO DE ESCOLHA DA ATIVIDADE?}

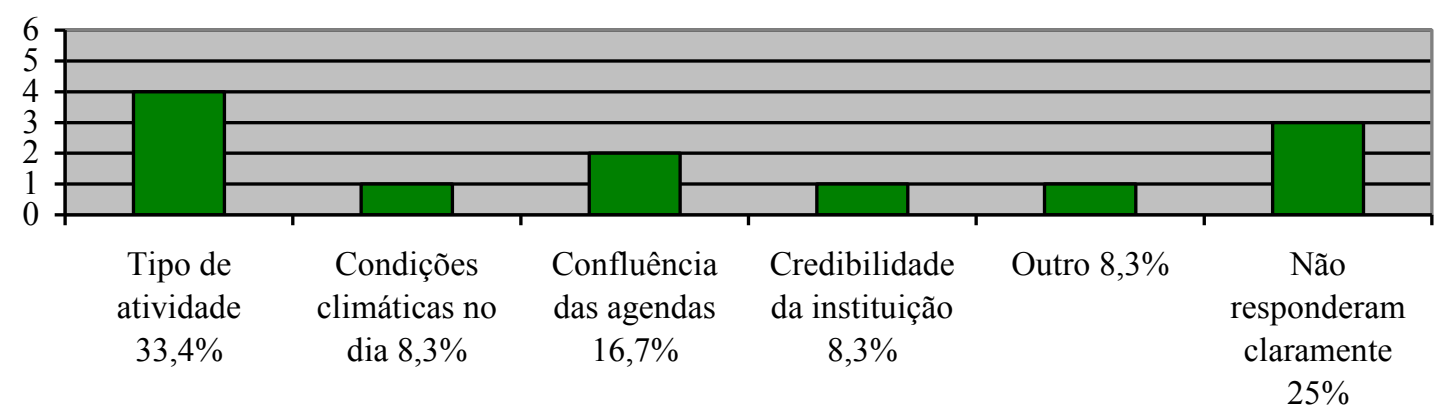

$\square$ número de famílias

Gráfico 20: Critério de seleção das atividades de lazer das famílias.

* Porcentagem calculada a partir do número de famílias entrevistadas: 12.

Para uma das famílias, as condições climáticas são um fator importante e decisivo na escolha de uma programação em família. Em dias chuvosos ou frios é mais difícil que pais de crianças optem por lugares ou trajetos onde haja exposição ao ar livre. É o caso do MAC USP do Parque Ibirapuera, na qual ocorre o Interar-te. Prevendo este aspecto do comportamento das famílias, o programa educativo foi planejado para público espontâneo, ou seja, não há necessidade de inscrição prévia; além disso considera-se esta atividade de lazer pertinente às 
opções das famílias em seu "tempo livre" e a não exigência de inscrição corrobora com essa liberdade.

A família 2, que não reside em São Paulo ou na Grande São Paulo ${ }^{45}$, apresentou uma informação diferente das apontadas pelas demais. A jovem comentou que, na cidade onde moram, a 360 km da cidade de São Paulo, não há opção de escolha pela falta de oferta. Nessa cidade não há teatro nem casa de espetáculo; há um único museu, um museu histórico. Para a jovem de 21 anos este fator aumenta a incidência do uso de álcool entre os jovens.

Pesquisadora: Vocês sentem falta de... de mais atividades na cidade... do que mais vocês sentem falta, aqui?

Jovem do sexo feminino: Ah... de ter um barzinho com música legal, cinema bom, shows...

Adulta: Shows, teatro... eu gostaria que tivesse teatro.

Jovem do sexo feminino: Ai, eu não vou muito a teatro.

Adulta: Grupos de dança... eu e a [cita sua irmã mais nova], a gente sempre ia...

Jovem do sexo feminino: Ah, mesmo na semana da AIA, só tem festa. Mas... a maioria do povo que vai, só vai porque tem festa pro povo beber, né, porque aqui o povo não se interessa por mais nada...

Pesquisadora: E o que é a Semana da AIA?

Jovem do sexo feminino: É a semana universitária.

Pesquisadora: E que tipo de programação tem?

Jovem do sexo feminino: Tem todo tipo de programação, tem festas à noite, tem teatro, discussão, competição de pipa, baralho.

Adulta: Palestras a respeito de todos os assuntos...

Pesquisadora: É uma vez por ano?

Jovem do sexo feminino: É, uma semana. (família 2)

PERgunta 2.3.4. ONDE CONSUltam A PROGRAMAÇ̃̃O DAS ATIVIDAdES QUE FREQUENTAM?

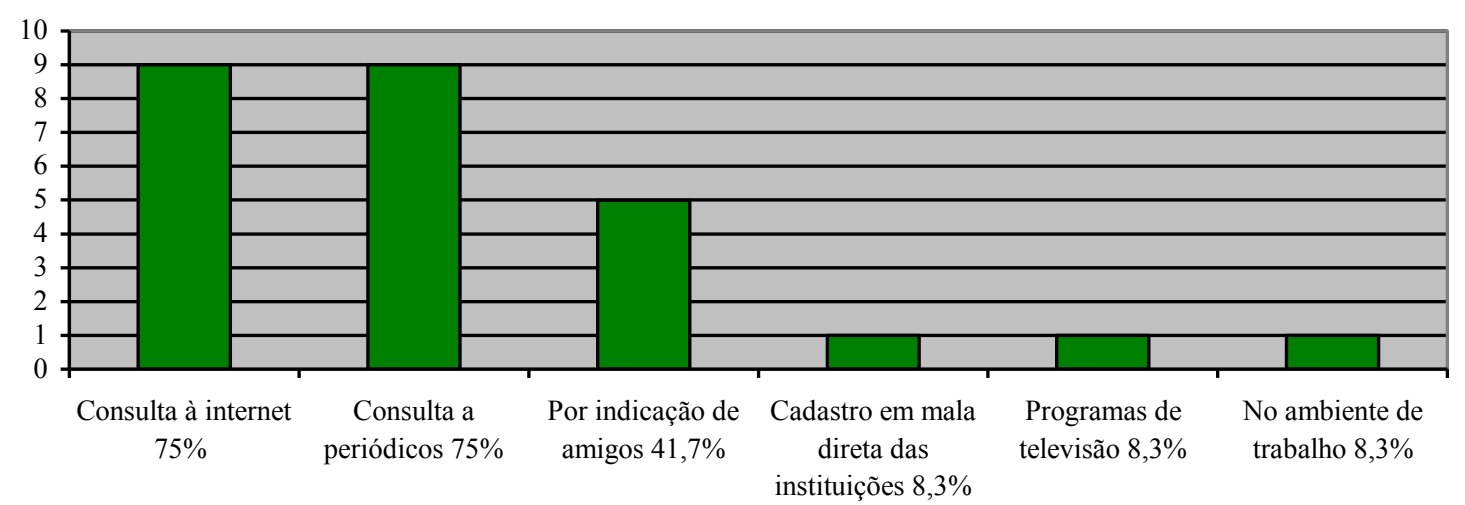

número de vezes citadas

Gráfico 21: Meio de divulgação consultado sobre programações para a família.

\footnotetext{
${ }^{45}$ Frequentam o programa no período de férias escolares, quando visitam parentes que moram em São Paulo.
} 
As famílias apontaram 6 diferentes formas pelas quais se informam sobre programações culturais. Cada depoimento indicou mais de uma forma. A porcentagem foi calculada pelo número de vezes que um determinado fator foi comentado pelas famílias, independente dela ter apontado mais de um fator ou não; 12 corresponde a $100 \%$.

\section{PERGUNTA 2.4. VERIFICAÇ̃̃O SOBRE O HÁBITO DE VISITAÇ̃̃O DE EXPOSIÇ̃̃ES DE ARTE:}

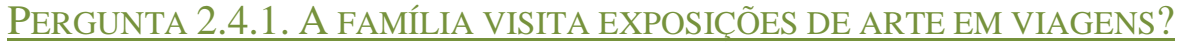

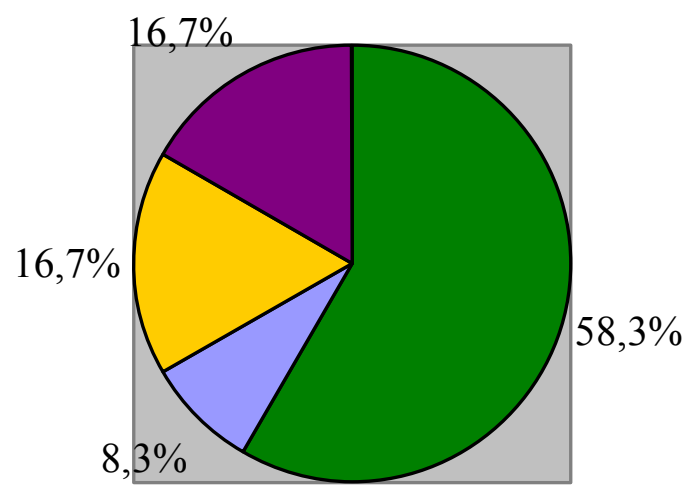

$\square \operatorname{sim}(7)$

$\square$ não (1)

$\square$ sim, para exposições em geral (2)

$\square$ não responderam a questão (2)

Gráfico 22: Frequência a exposições de arte em viagens.

* Porcentagem calculada a partir do número de famílias entrevistadas: 12.

A adulta da família 1 comentou que as viagens que realizam são, na maioria, para cidades do interior do Estado de São Paulo, nas quais não há museus de arte e as exposições de arte em outras instituições são raras. Quando estas cidades possuem um museu, este é histórico. Como exemplo, citou em seu depoimento as cidades de Holambra e Amparo, para as quais já viajou e procurou visitar os museus locais. 
PERGUNTA 2.4.2. A FAMÍlIA OU O ADULTO TEM CONHECIMENTO DA EXISTÊNCIA DE ALGUMA INSTITUIČÃO CULTURAL OU ATELIÊ DE ARTISTA PRÓXIMOS DE SUA RESIDÊNCIA, EM SEU BAIRRO? EM CASO AFIRMATIVO, JÁ OS VISITOU?
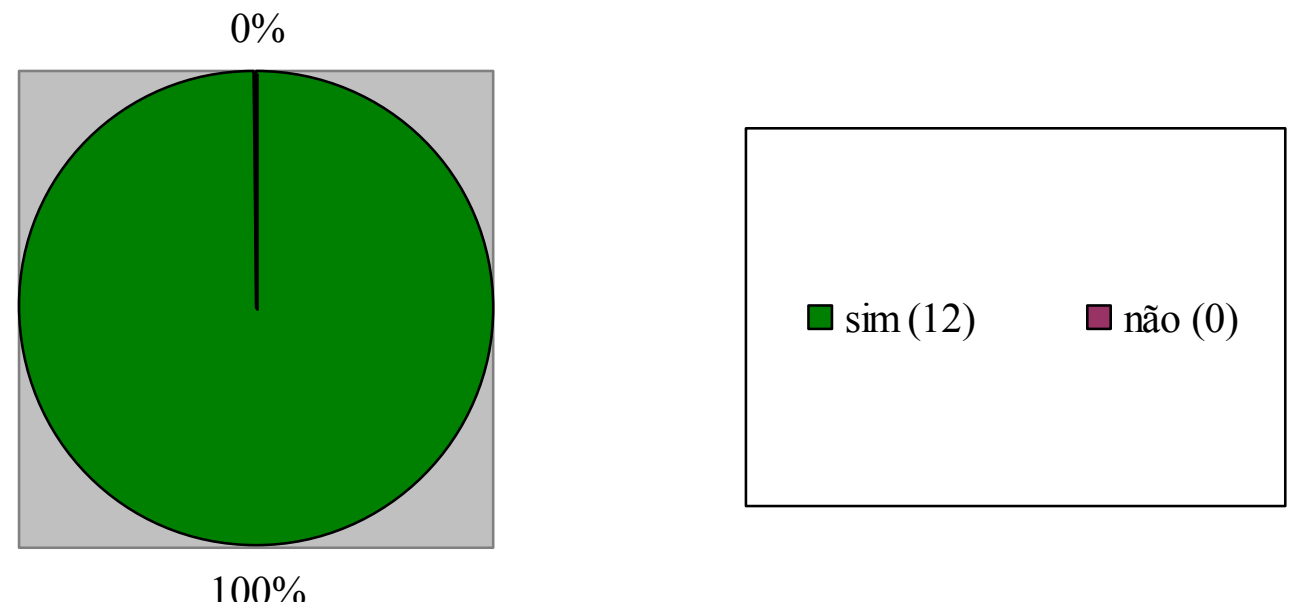

$100 \%$

Gráfico 23: Existência de instituição cultural próxima à residência dos adultos.

* Porcentagem calculada a partir do número de famílias entrevistadas: 12.
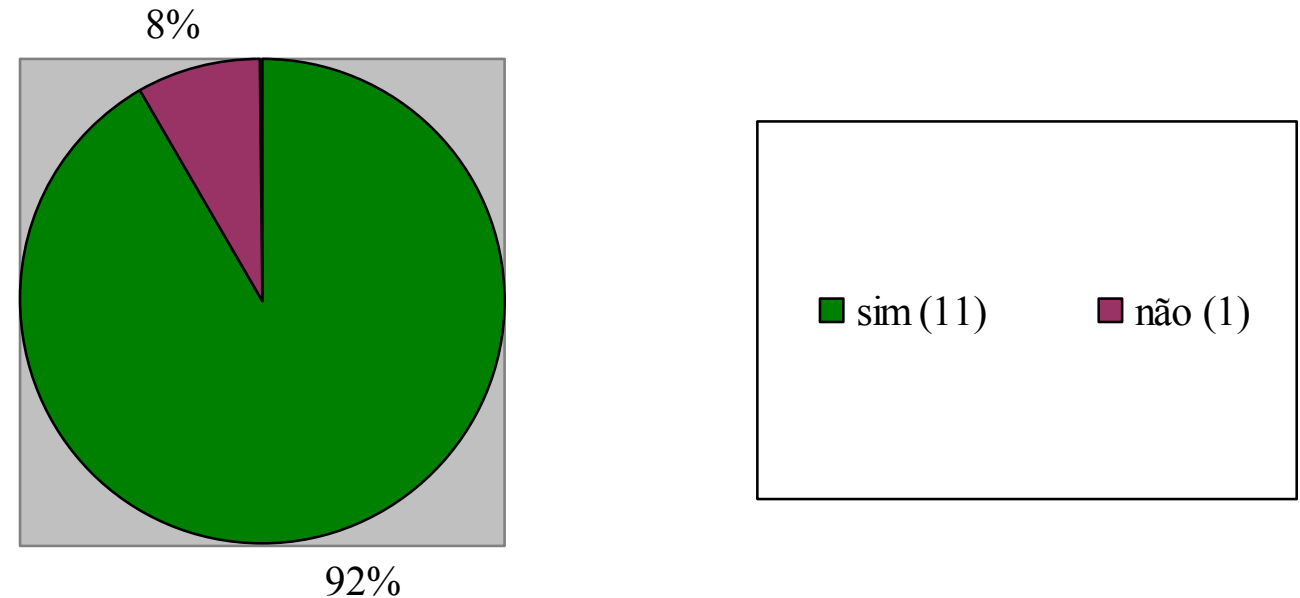

Gráfico 24: Visitação ao local citado no Gráfico 23.

* Porcentagem calculada a partir do número de famílias entrevistadas: 12. 
PERGUNTA 2.4.3. OS ADULTOS VISITAM EXPOSIÇÕES SOZINHOS, SEM AS CRIANÇAS E ADOLESCENTES?

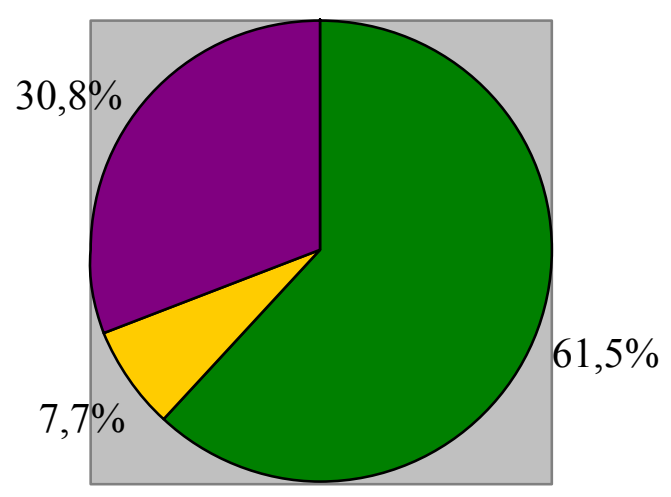

$\square \operatorname{sim}(8)$
$\square$ não (1)
$\square$ não respondeu (4)

Gráfico 25: Visitação de adultos a exposições de arte sem a companhia de crianças e jovens.

* Porcentagem calculada considerando os 13 adultos entrevistados.

\section{PERGUNTA 2.4.4. QUAL EXPOSIÇÃO MAIS MARCOU OS ADULTOS?}

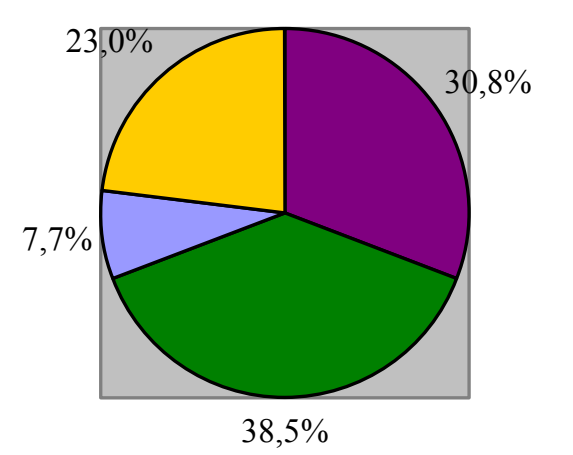

$\square$ em instituição cultural na cidade de moradia (4)

$\square$ em instituição cultural conhecida em viagem (5)

$\square$ outro (1)

$\square$ não respondeu (3)

Gráfico 26: Exposição visitada pelos adultos que lhes foi mais significativa, por modalidade (local).

* Porcentagem calculada considerando os 13 entrevistados adultos como base. Destaca-se que o casal entrevistado da família 12 apresentou opinião diferente.

A família 2, que reside em cidade do interior na qual não há museus de arte, comentou que visitou uma exposição de pinturas de uma artista que reside na mesma cidade num clube local. No gráfico acima este dado consta no item "outro", uma vez que a exposição não ocorreu em uma instituição como museus ou centros culturais, denominados no Gráfico 26 como "instituições culturais". 
PERGUNTA 2.4.5. QUAL EXPOSIC̨ÃO MAIS MARCOU AS CRIANÇAS E JOVENS ?

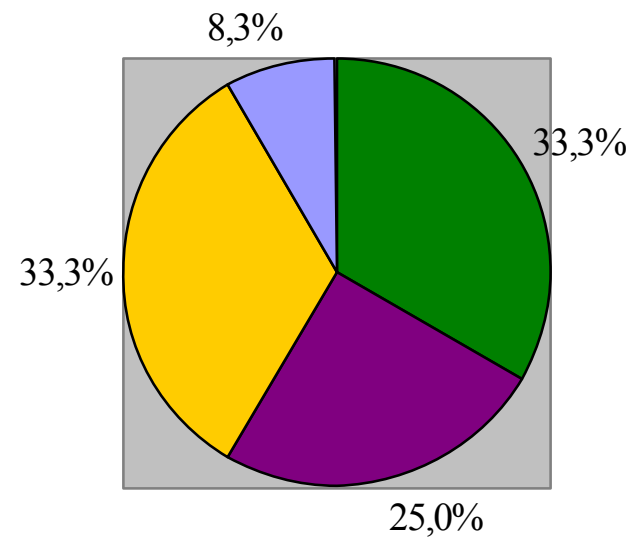

$\square$ em instituição cultural na cidade de moradia (4)

em instituição cultural conhecida em viagem (3)

$\square$ não responderam(4)

$\square$ famílias com crianças ou adolescentes não entrevistados (1)

Gráfico 27: Exposição mais significativa para as crianças e jovens, por família, por modalidade (local).

* Cálculo de porcentagem considerando o universo de 12 famílias entrevistadas.

\section{PERGUNTA 2.4.6. QUANTAS VEZES, EM UM ANO, AS CRIANÇAS E ADOLESCENTES VISITAM EXPOSICCÕES DE ARTE COM A ESCOLA E COM A FAMÍLIA?}

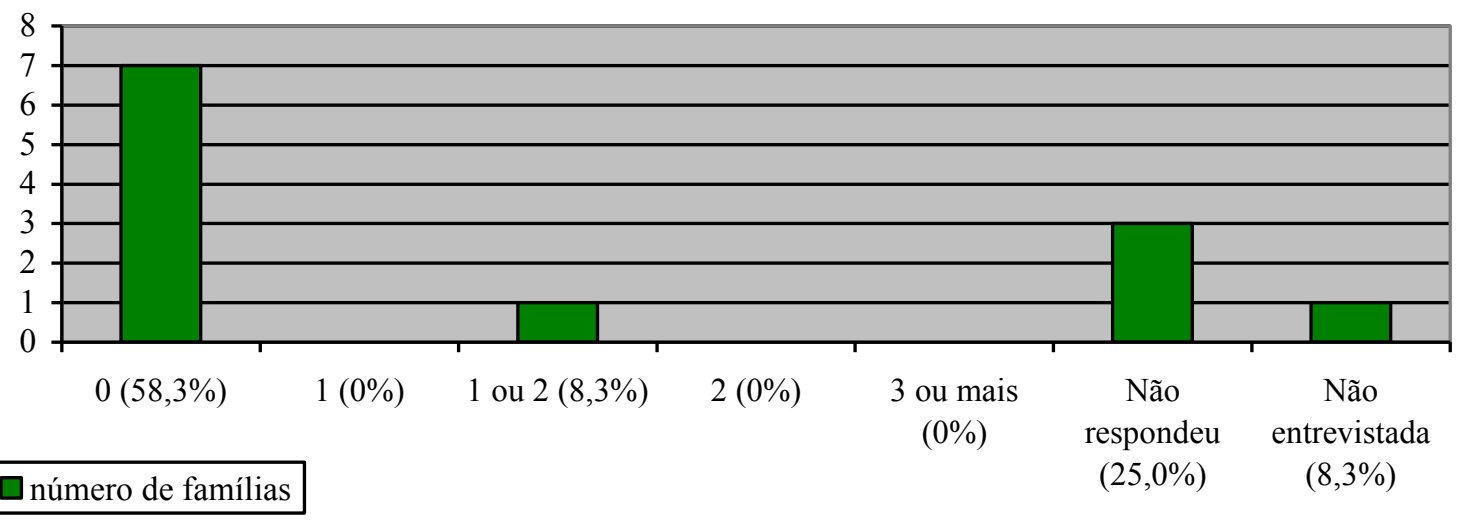

Gráfico 28: Frequência anual das crianças e jovens a exposições de arte com a escola, por família.

* Cálculo de porcentagem considerando o universo de 12 famílias entrevistadas. A família 8 não teve criança ou jovem entrevistado.

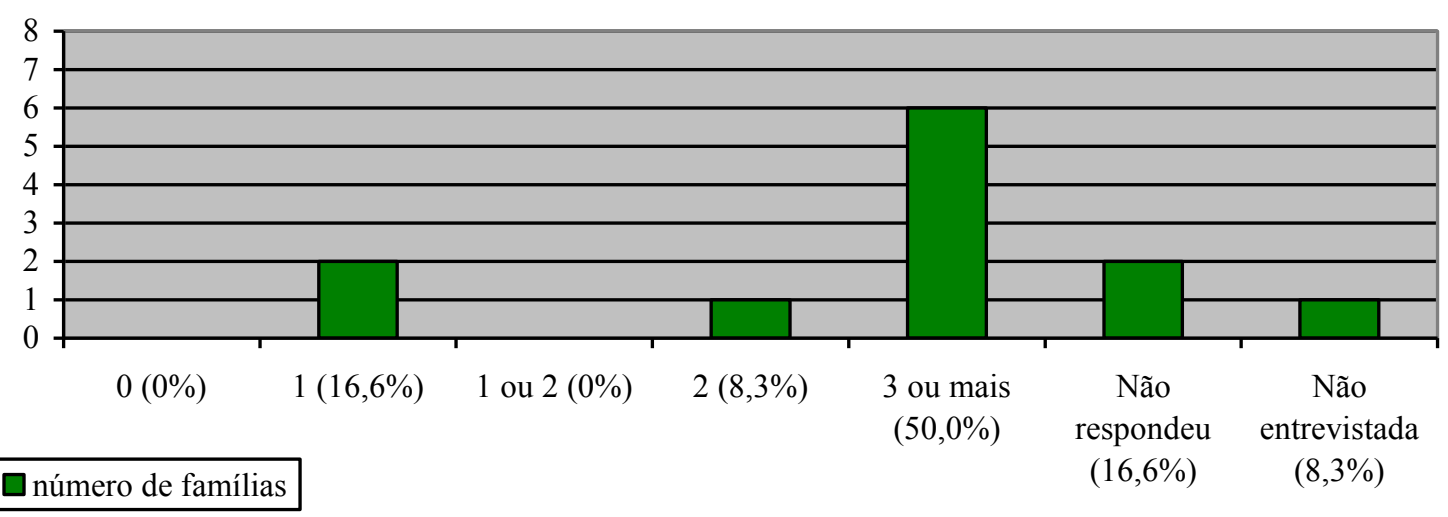

Gráfico 29: Frequência anual das crianças e jovens a exposições de arte com a família, por família.

* Cálculo de porcentagem considerando o universo de 12 famílias entrevistadas. A família 8 não teve criança ou jovem entrevistado. 
Diante dos dados apresentados nos Gráficos 28 e 29, acima, observa-se que se vai muito mais a exposições de arte com a família do que com a escola. Da amostra, 58,3\% não vai a exposições de arte com a escola, enquanto que 9 entre as 12 famílias (75\%) vão, no mínimo, uma vez ao ano a exposições de arte. Destaca-se, ainda, que 50\% da amostra vai 3 vezes ou mais ao ano a exposições de arte. Os depoimentos colhidos indicam um aumento neste índice de frequentação, conforme o gráfico abaixo.

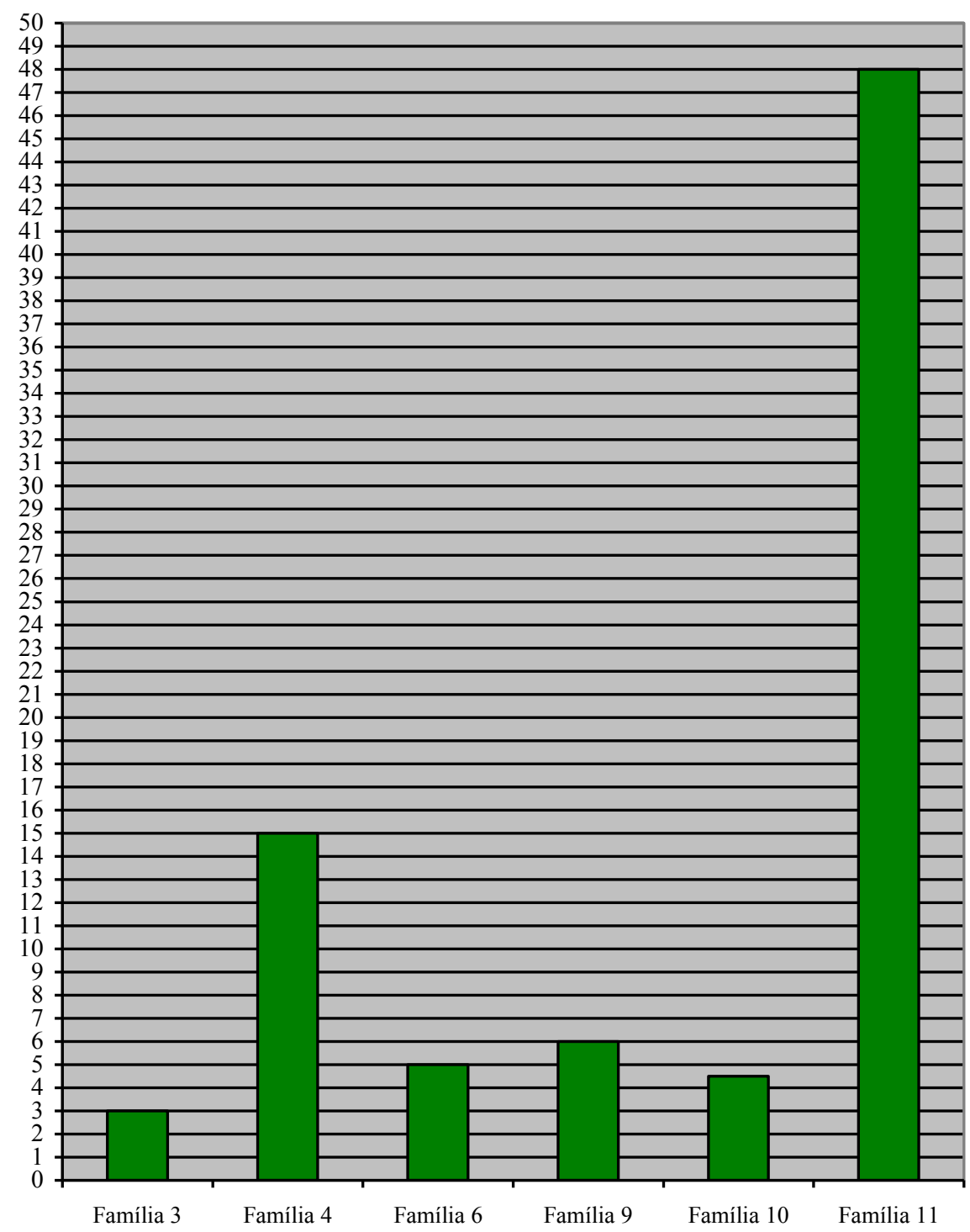

$\square$ número de vezes

Gráfico 30: Frequência anual a exposições de arte das famílias que declararam frequência maior ou igual a 3.

A adulta da família 11 trabalha com artes visuais (pesquisa e curadoria) e costuma levar a família em visitas a exposições. Esta atividade, no caso dela, pode ser caracterizada como de "ócio produtivo" e explica o alto índice de frequência da família dela a exposições. 
A programação destinada ao estudo do meio que as escolas de educação básica promovem implica no planejamento de professores de várias áreas do conhecimento; os de disciplinas como História, Artes e Literatura, com alguma frequência, incentivam visitas a exposições de artes visuais. No entanto, diante do programa anual de atividades dessa natureza, visitas a exposições de arte, quando habituais dentre as estratégias de ensino e aprendizagem das escolas, chegam a ocorrer uma vez ao ano, com exceção em anos de eventos como grandes mostras de intensa divulgação nos meios de comunicação de massa ou Bienais de São Paulo.

O fato de alguns jovens estarem cursando o ensino médio na época da entrevista dificultou a coleta de informações em relação à Pergunta 2.4.6. Nesse caso, tanto as escolas não realizam atividades extracurriculares quanto eles próprios, nos momentos de lazer, restringem as atividades de lazer para dedicação aos estudos preparatórios ao exame vestibular, como podemos constatar na declaração de uma das jovens entrevistadas:

Diante dos resultados e da análise dos Gráficos 29 e 30, podemos inferir que os adultos das famílias da amostra incentivam a formação de hábito de frequentação a exposições de arte das crianças e jovens. 
PERGUNTA 2.5. AOS ADULTOS ENTREVISTADOS QUE SÃO OS PAIS DOS PARTICIPANTES DO INTERAR-TE: QUANDO A ESCOLA DOS FILHOS REALIZA ATIVIDADE CULTURAL EXTRACLASSE, VOCÊS INCENTIVAM? BUSCAM SABER ONDE É A ATIVIDADE? CONVERSAM COM AS CRIANCCAS OU ADOLESCENTES SOBRE ESTA EXPERIÊNCIA, DEPOIS?

Nove respondentes entre os 13 entrevistados nas 12 famílias da amostra são pais das crianças ou jovens acompanhados ao programa Interar-te.

\begin{tabular}{|l|c|c|}
\hline $\begin{array}{c}\text { Receptividade/conduta dos pais sobre atividades extraclasse } \\
\text { realivadas pela escola dos fillhos }\end{array}$ & sim & $\% *$ \\
\hline Há incentivo à participação dos filhos & 9 & 100 \\
\hline Busca saber sobre a atividade antes da realização & 9 & 100 \\
\hline Conversa depois com os filhos & 9 & 100 \\
\hline
\end{tabular}

Quadro 10: Conduta dos entrevistados adultos, pais das crianças e jovens, sobre atividades escolares extraclasse.

* Porcentagem calculada considerando como base os 9 adultos que são pais dos participantes do Interar-te.

Alguns pais apontaram que é preciso insistir com os filhos para que conversem sobre alguma atividade extraclasse.

Pesquisadora: E... depois que elas chegam, você conversa com elas pra saber como foi? Adulta: Muito, muito... exaustivamente. Quando elas conseguem me contar alguma coisa: “ah, mãe, foi legal” (risos) (família 3)

Pesquisadora: Quando elas tinham, na escola, atividade cultural extraclasse, você incentivava, buscava saber onde era, conversava com elas depois?

Adulto: Sim, incentivava bastante, tentava, né, conversar depois. Nem sempre a gente tinha retorno, mas eu sempre me esforçava em conversar, mas nem sempre a comunicação era fácil, ou é fácil. (família 9)

Adulta: E quando eles voltam a gente sempre procura saber, o que eles fizeram lá, o que eles viram... às vezes se eles não sabem dizer muita coisa, a gente tenta puxar, dá umas cutucadas... Adulto: ...cutuca... às vezes eles não são muito de falar, né?

Adulta: ... como é que era, você foi lá e só tomou lanche, não tinha nada, não tinha um teatro, né, como é o caso da Cidade do Livro que tem um teatrinho, tem um monte de coisa, então a gente vai puxando essas coisas e sempre é legal... eles sempre trazem mais - principalmente a M. Agora,sempre traz bastante coisa. (família 12)

Uma entrevistada demonstrou que se empenha para incentivar a participação do filho quando a atividade é em locais desconhecidos pela criança:

Pesquisadora: E você busca saber sobre a atividade antes dele ir, quando você não conhece o lugar?

Adulta: Eu procuro na internet, olho antes, mostro pra ele. (família 10)

Esta conduta da mãe insere-se nas ações preparatórias para uma atividade de estudo do meio. Sabe-se da importância da programação anterior à saída, assim como da continuidade 
do trabalho na escola, chamado de desdobramento. Como se trata de uma atividade escolar, essa atitude demonstra o apoio e o compromisso da família às atividades escolares.

PERGUNTA 2.6. AOS ADULTOS ENTREVISTADOS QUE SÃO OS PAIS DOS PARTICIPANTES DO INTERAR-TE: COMPRAM LIVROS, APRESENTAM MÚSICAS E FILMES AOS FILHOS? ACOMPANHAM OS QUE ELES CONHECEM, MESMO QUE NÃO SEJA NA ÍNTEGRA?

\begin{tabular}{|l|c|c|}
\hline \multicolumn{1}{|c|}{$\begin{array}{c}\text { Receptividade/conduta dos pais sobre oferta e ciência dos } \\
\text { produtos culturais dos filloos }\end{array}$} & sim & $\% *$ \\
\hline Fornecem produtos culturais aos filhos & 9 & 100 \\
\hline Acompanham programação cultural dos filhos & 9 & 100 \\
\hline
\end{tabular}

Quadro 11: Conduta dos entrevistados adultos, pais das crianças e jovens, sobre os produtos culturais que os filhos consomem.

* Porcentagem calculada considerando como base os 9 adultos que são pais dos participantes do Interar-te.

É comum, nos depoimentos, observar que os pais reduzem a oferta de produtos culturais quando os filhos entram na adolescência. Livros e músicas são compartilhados com amigos da mesma faixa etária, assim como ir ao cinema.

\section{PERGUNTA 2.7. QUAL É O PONTO DE VISTA DAS CRIANCCAS E ADOLESCENTES: DENTRE AS ATIVIDADES INDICADAS (ASSISTIR FILME OU IR AO CINEMA; OUVIR MÚSICA OU IR A ESPETÁCULOS MUSICAIS; IR A EXPOSIC̄ÕES; OUTROS: INDICAR) O QUE ELES PREFEREM FAZER COM OS PAIS OU COM OS ADULTOS PRÓXIMOS DA FAMÍLIA? POR QUÊ?}

Foram entrevistadas 15 crianças e adolescentes entre as 12 famílias da amostra respondente à pesquisa.

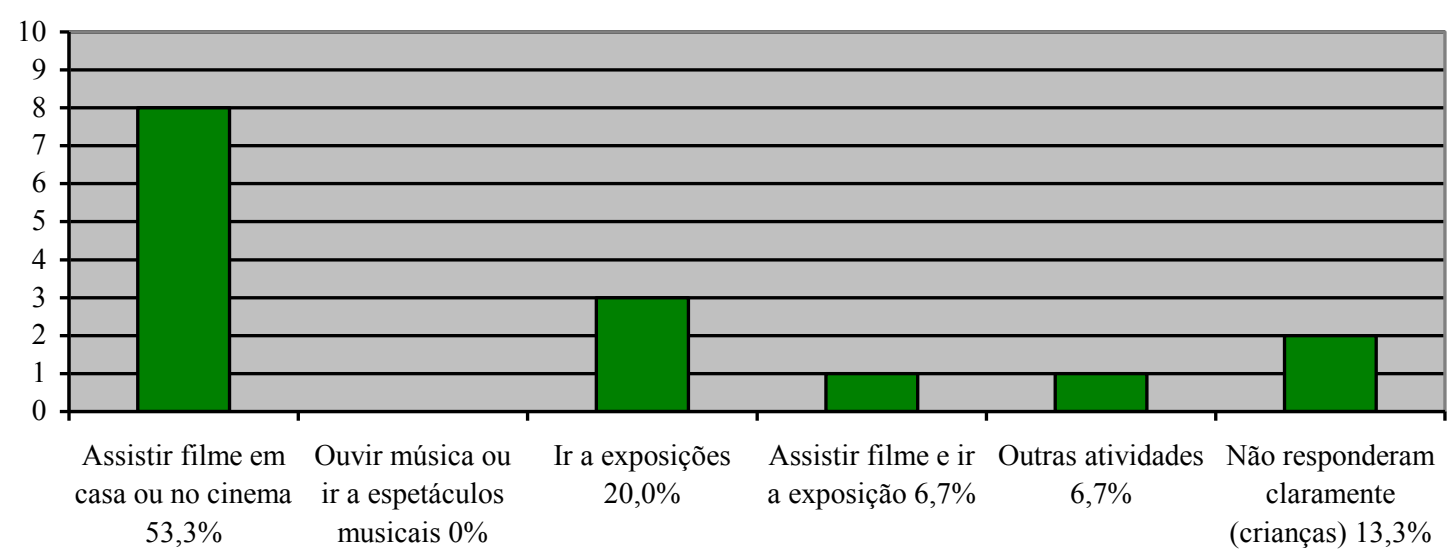

$\square$ número de respondentes

Gráfico 31: Preferência de crianças e jovens sobre práticas culturais para realizar na companhia de adultos.

* Porcentagem calculada considerando as 15 crianças e jovens entrevistados. 
PERGUNTA 2.8. QUAL É O PONTO DE VISTA DAS CRIANÇAS E ADOLESCENTES: JÁ FORAM A EXPOSICCÕES DE ARTE COM A ESCOLA? É IGUAL OU DIFERENTE DAS VISITAS COM OS PAIS OU COM OUTROS ADULTOS PRÓXIMOS DA FAMÍLIA? POR QUÊ?

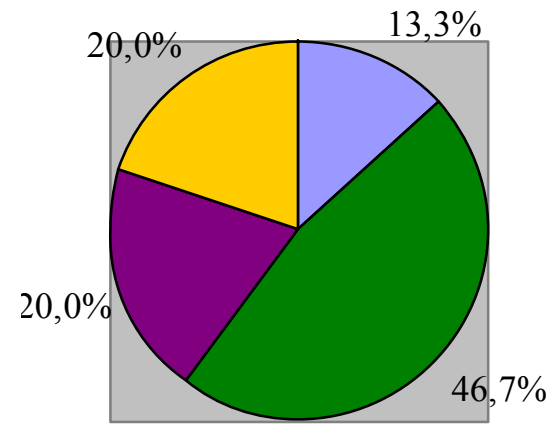

igual (2)

diferente (7)

não vai a exposições com a escola (3)

não respondeu objetivamente (3)

Gráfico 32: Opinião comparativa das crianças e jovens sobre visitar exposições com a família e com a escola.

* Porcentagem calculada considerando as 15 crianças e jovens entrevistados.

No gráfico abaixo, indicamos a preferência dos 7 entrevistados que disseram ser diferente visitar exposições com os pais e com a escola.

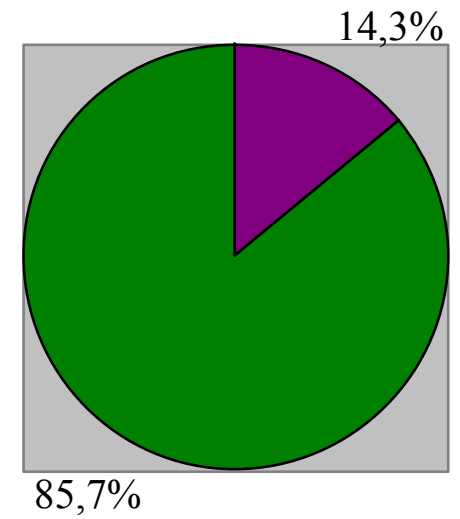

escola (1)

família (6)

Gráfico 33: Preferência de 7 crianças e jovens entre ir a exposições com a escola e com a família.

* Para base de cálculo de porcentagem, 7 corresponde a $100 \%$.

A única respondente que disse preferir ir com a escola a exposições foi uma criança do sexo feminino, de 8 anos, da família 5; ela justificou a preferência pelo fato de que, com a escola, poder estar com os amigos. Para esta estudante, a sociabilidade é valorizada nas atividades promovidas pela escola. Sabe-se que a escola é um locus de aprendizagem e de convívio privilegiado para as crianças, no qual se pode ter contato com valores diferentes dos adquiridos no interior do ambiente familiar.

A importância da sociabilidade também foi comentada por outra criança, uma menina de 11 anos (família 1). Ela foi ao programa Interar-te com uma amiga da família, vizinha de sua avó, que reunia crianças e lhes proporcionava momentos de lazer em parques, lanchonetes e no museu em que é funcionária. A menina, que sempre esteve presente nesses grupos, ao ver 
as imagens de sua participação no Interar-te antes da entrevista, demonstrou entusiasmo ao identificar suas amigas ${ }^{46}$. Isso ganhou relevância na observação de um desenho solicitado à menina (cuja imagem será apresentada adiante, em comentário à Pergunta 3.3), quando da investigação da opinião das famílias sobre a participação no Interar-te

Em contrapartida, entrevistados adolescentes apontaram a presença de amigos como motivo para preferirem visitar exposições com os pais e não com a escola. Para eles, os colegas de classe os distraem e tiram o foco do contato com as obras:

Pesquisadora: Quando você vai a uma atividade com a escola - ou com seus pais - é diferente, pra você?

Adolescente: É...

Pesquisadora: Qual a diferença?

Adolescente: Quando eu vou com a escola, eu não vou prestar tanta atenção, porque eu vou tá com os meus amigos e... com os meus pais eu vou prestar atenção porque... porque eu tô com os meus pais. Mas não quer dizer que eu não preste atenção nas coisas da escola, eu até falo pra minha mãe: ah mãe não sei que que eu fiz... na exposição, no lugar... (...) (família 7)

Pesquisadora: Mesmo pensando no Museu da Língua Portuguesa, quando você vai com a escola, ou você vai com os seus pais, você percebe alguma diferença?

Adolescente: Eu acho que sim, porque com a escola tem os amigos, que não querem prestar atenção em nada, então eles ficam falando. Mas eu ,como gosto de ver isso, sempre gostei, então acho que eles não interferem muito, porque eu ignorava: ia ver e me divertia e, depois, quando dava um tempo eu falava com eles.

Pesquisadora: E com os seus pais como é?

Adolescente: Ah... é legal, tipo a gente tá vendo e de repente: Ah... olha isso daqui que legal. E aí comenta alguma coisa que o outro não tinha percebido, ou então junta dois pontos de vista e fala: nossa, é verdade, não sei o que...! (família 9)

PERGUNTA 3.1 POR QUE O ADULTO OPTOU POR PROPORCIONAR A EXPERIÊNCIA DO PROGRAMA INTERAR-TE A CRIANCAS E ADOLESCENTES?

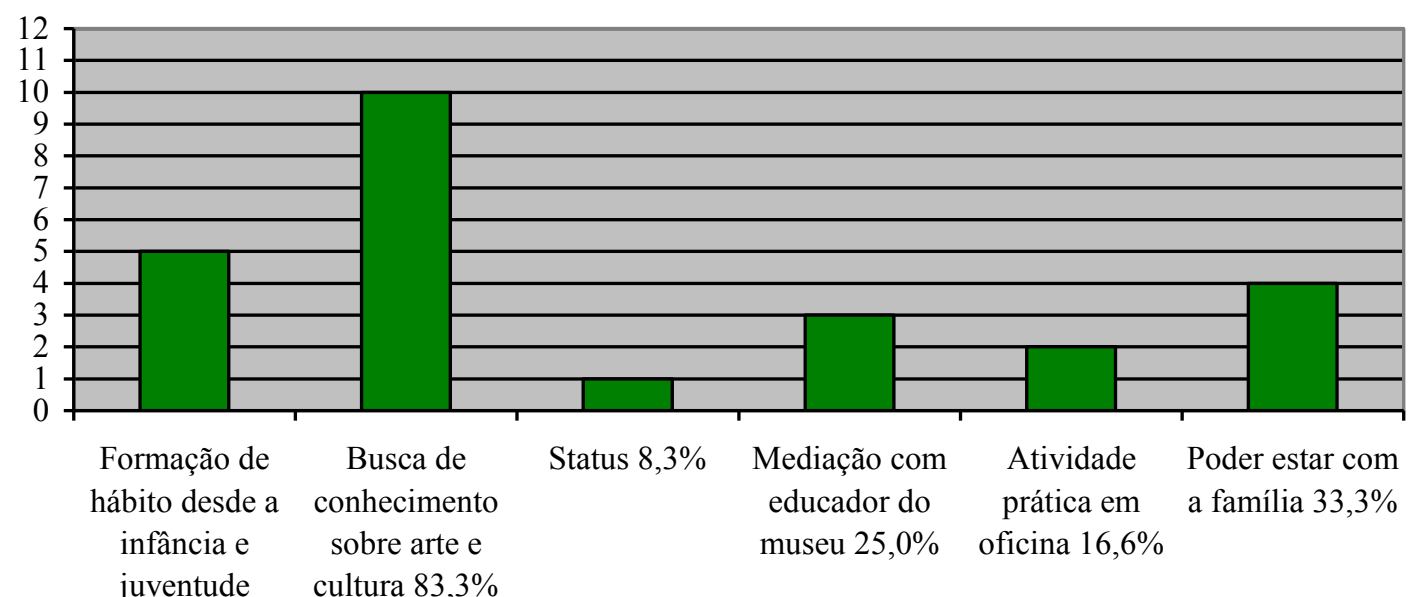

cultura $83,3 \%$

número de vezes

Gráfico 34: Motivos indicados pelos adultos para frequentarem o Interar-te.

* Houve indicação de mais de um motivo por família. Para cada categoria calculou-se a porcentagem. considerando as 12 famílias entrevistadas.

\footnotetext{
${ }^{46}$ Dado registrado no diário de campo da pesquisadora.
} 
Para 10 das 12 famílias entrevistadas (83,3\%), o principal motivo de frequência ao programa Interar-te é a aquisição de conhecimento sobre arte e cultura que a atividade proporciona. A formação do hábito de frequentação a instituições culturais desde a infância e adolescência é o segundo fator, indicado por 5 das 12 famílias (41,7\%).

O pai de dois meninos, um de 5 e outro de 8 anos (família 4), explicou o porquê de levá-los ao Interar-te: “Ah... a satisfação e o compromisso de proporcionar esse contato... de arte... logo no começo da vida, na infância, antes da juventude." Para ele, a infância é momento da formação de hábitos, com os quais a família de origem pode contribuir. Sua percepção em relação ao comportamento dos adolescentes está de acordo com os dados da pesquisa (Pergunta 2.3.1.). Pudemos observar que os adolescentes afastam-se da companhia dos pais e buscam aproximar-se dos amigos. Investindo na formação dos hábitos culturais das crianças, os pais contribuem para proporcionar um repertório mais amplo de experiências aos jovens que perdura na vida adulta.

Diante dos índices apresentados no Gráfico 34 acima podemos afirmar que as famílias frequentam o programa Interar-te em busca de aquisição de conhecimentos sobre arte e cultura, assim como de formação de hábitos de frequentação a instituições culturais para as crianças e jovens.

A possibilidade de estar em família, participando de uma atividade que envolve todos, contemplando as diferentes faixas etárias - um dos objetivos do programa -, foi o terceiro fator mais indicado. Pudemos constatar como os familiares se manifestam em situações que fogem das habituais da convivência cotidiana, além do próprio tempo que destinam para estarem juntos (ao optarem pela participação no Interar-te). Isso fica evidenciado nos depoimentos a seguir:

Pesquisadora: Sobre o programa Interar-te, por que você escolheu proporcionar essa experiência para eles?

Adulta: Eu, quando li a proposta achei muito interessante... a questão da família... ser uma atividade que prevê a família junta porque, às vezes, é difícil conseguir um programa... ou é muito específico e direcionado pra criança, ou é pro adulto, mas tem poucas coisas que a gente encontra assim que são... pra que a família participe né. E com essa correria toda que a gente vive, a gente cada vez tem menos tempo pra estar ali reunido, estar junto, fazer alguma coisa junto; então eu achei muito boa a ideia de uma atividade... e também porque... as crianças, pra eles tudo é divertido, é diversão, mas a participação do pai né, normalmente, principalmente... às vezes é mais difícil né, eles nem sempre se interessam, ou até querem estar junto, participar mais de alguma coisa, mas não veem como, hoje. Eu não sei, eu tenho a impressão de que, apesar de não me lembrar muito de... dos meus pais brincando exatamente comigo, ,estavam mais próximos. Minha mãe, principalmente né, não trabalhava... o tempo todo em casa... então, tudo que queria, precisava, qualquer interrogação que tivesse, tava ali pra responder. E hoje em dia, não. Então, tudo que é pra poder fazer junto eu procuro fazer, né, e às vezes a gente, ficando em casa, a gente fala... Ah... vou ficar em casa, vou brincar... Não, não faz! Então a gente, procurando alguma coisa desse tipo, e como estamos começando a conviver nesse meio 
de arte, né, eu acho que é uma coisa que é importante, que é legal que eles conheçam, que eles convivam. (família 5)

Pesquisadora: Pensando agora no Interar-te, por que você quis proporcionar essa experiência para suas filhas?

Adulto: Eu penso que é fruto... pra mim, eu sempre penso que é fruto da angústia, eu não acredito que isso sirva... pra universalizar... porque cada um tem a sua história e o seu sentimento. Eu acho que, no meu caso, é sempre fruto da angústia. Fruto da angústia e da dificuldade de travar diálogos, de organizar ações... é sempre muito difícil alcançar o objetivo de um diálogo, duma convivência que termine a convivência e você fale: poxa, isso foi legal! O sentimento fica legal, o sentimento fica acomodado. Aí, a possibilidade de vivenciar o Interarte é como vivenciar a terapia, eu acho que é uma sessão de terapia, é uma sessão de... nos encontramos. Agora não tem rota de fuga, não dá pra falar: não enche o saco vai!...Não dá pra rosnar... (risos). Ninguém rosna pra ninguém... eu acho que é uma grande possibilidade. Não é fácil parar de rosnar, não é fácil. (família 9)

Dois dos 12 entrevistados (16,7\%) apontaram que um fator importante para decidiremse por frequentar o programa do MAC USP é a aprendizagem pela vivência de práticas artísticas. Eles relataram a aprendizagem de procedimentos artísticos, a manipulação de materiais e a possibilidade de uma diversidade de resposta às situações criadas - quando do cumprimento dos exercícios propostos na etapa do programa destinada às oficinas, no ateliê do Museu. Esta concepção de aprendizagem vai ao encontro de Dewey (2005). Podemos verificar esta devolutiva no depoimento:

Pesquisadora: Sobre o programa Interar-te, que você veio com as meninas duas vezes: por que você quis proporcionar essa experiência pra elas?

Adulta: Porque eu acho o máximo! Assim... eu fiquei encantadíssima com o programa, eu já falei isso milhões de vezes, você sabe, eu sou fã de carteirinha, e eu fiquei encantada com essa possibilidade de... delas virem no museu e de ter uma pessoa que vai ser... se aprofundar mais naquele tema do artista, e pudesse trazê-las para fazer alguma coisa... Porque eu acho que, quando a gente manipula a matéria, a gente diz muito, né, a gente expressa muito - o que eu acho fundamental, principalmente pra uma criança (...). Acho que tem uma preocupação de preparar o encontro, né, de ir a fundo. Eu acho que esse programa é uma coisa que traz a gente, traz a família pro museu - e mesmo que não esteja completamente inteirado de arte, quando chega aqui, se sente completamente à vontade. Como aquele meu amigo, que era matemático da USP, faz Pós-Doc nos Estados Unidos e tal, sempre me fala: "eu gostei muito", ele sempre me fala: "eu gostei muito daquele programa". Então, é cuidadosamente preparado e essa relação que você faz, entre a obra de arte...fica algo... que atinge, né. Eu ia falar desvendada, mas a obra de arte nunca é completamente desvendada, é que atinge as crianças e o adulto... eu acho fantástica. E o cuidado, um preparo que vocês têm,... de trazer os materiais, de estar com tudo... né, materiais muito simples, que eu acho que é por aí mesmo - e que, de fato, trazem essa possibilidade da criança e do adulto também se apropriar de uma linguagem que talvez nunca tenha se dado ao luxo, ou se dado tempo de fazer. É esse tempo que a gente tá precisando, esse tempo de parar, de olhar, de... contemplar, né, de discutir questões que eu acho que têm a ver muito com a... com tudo, né, com a minha vida, com a vida do outro, o mundo... Acho bem bacana. (família 3) 


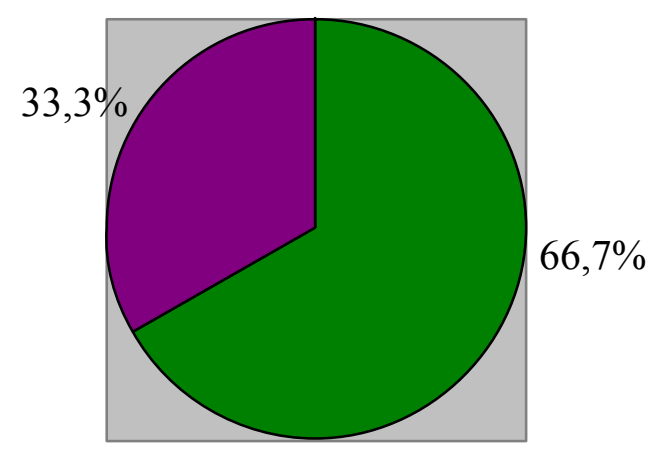

$\square$ divulgação da instituição (8)

$\square$ indicação de conhecido (4)

Gráfico 35: Modo de conhecimento do programa Interar-te.

* Porcentagem calculada com base no universo de 12 famílias.

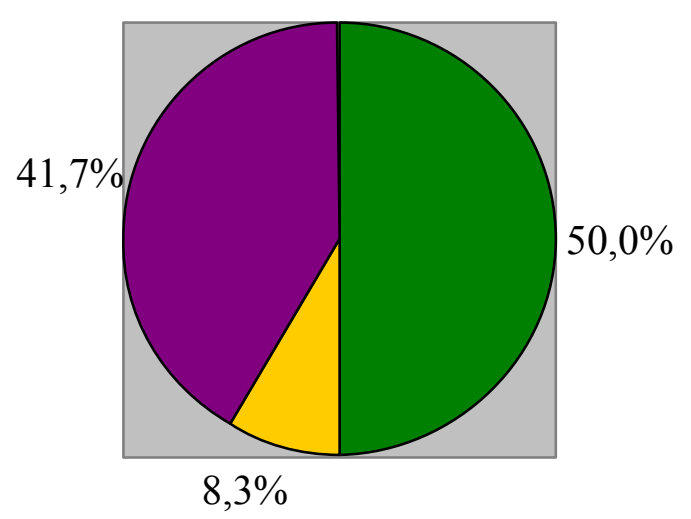

adulto (6)

todos, de comum acordo (1)

não respondeu (5)

Gráfico 36: Membro da família que optou por participar do Interar-te.

* Porcentagem calculada com base no universo de 12 famílias.

Os adultos foram os responsáveis pela escolha de participação no Interar-te em $50 \%$ das famílias e apenas um (8,3\%) discutiu a opção com os acompanhantes menores. Considerando que quando participaram do Interar-te 76,5\% das crianças e adolescentes entrevistadas eram crianças com idade entre 5 e 12 anos, fica evidente o papel decisório dos adultos na seleção das atividades para crianças.

Após os 13 anos, aproximadamente, os jovens começam a optar por atividades que não requerem a presença dos pais; adquirem uma independência parcial e sair com os amigos torna-se mais atraente. Conforme o diálogo entre mãe e filha da família 7 (citado à p.92), a adolescente de 13 anos na época da entrevista exemplifica essa mudança de comportamento dos menores em relação às atividades de lazer em família, e é representativa de outros agrupamentos. 


\section{PERGUNTA 3.3 COMO FOI, PARA A FAMÍLIA, PARTICIPAR DO INTERAR-TE?}

Para a coleta de informações sobre essa questão foram necessários instrumentos de pesquisa diferentes: um para os adultos e adolescentes (entrevista semiestruturada) e outro para as crianças (entrevista semiestruturada e a técnica de apoio de solicitação de desenho, com registro em diário de campo da fala espontânea dos entrevistados e suas respostas às indagações da pesquisadora).

Os desenhos com os depoimentos das crianças, na íntegra, seguidos de observações da pesquisadora, foram organizados no Apêndice 1.2 ao final da pesquisa.

Esta questão motivou muitos comentários indefinidos e vagos, como "gostei" e "foi interessante". Por essa razão não é apresentado um resultado quantitativo, em quadros e gráficos. Optamos por destacar depoimentos que indicam o conhecimento da arte e da importância da integração dos membros familiares quando da participação nas programações do Interar-te.

Algumas indicações nesse sentido já foram dadas em respostas a questões anteriores, cujo objetivo era a investigação destes temas.

No depoimento abaixo, a jovem que foi ao Interar-te com o pai, pela primeira vez, aos 16 anos, ressalta a aquisição de conhecimento sobre procedimentos artísticos da arte contemporânea, os quais ela compara com os meios e materiais tradicionais das artes visuais. Também trata da reverberação da aprendizagem em sua família: a mãe ficou sabendo do trabalho e seu significado (assim como os demais familiares e amigos que não estiveram presentes no Museu) ao visualizar o objeto produzido na oficina quando exposto no ambiente doméstico. O produto da oficina no Museu funcionou como o registro daquele momento e passou a constituir parte da memória familiar sobre o programa, propiciando que fosse compartilhado.

Pesquisadora: E pra você, como foi participar com o seu pai da atividade?

Adolescente do sexo feminino: Ah... eu acho que foi interessante porque, no programa, a gente descobriu uma arte nova, porque as que eu via... as de tintas, eu sabia, eu tinha noção... mas a outra que eu vi, não [participou de atividades na exposição sobre Bonadei, com muitas pinturas e na exposição Arte Contemporânea - Aquisições Recentes, onde houve trabalho a partir de um objeto da artista Nina Moraes]. Então são coisas que a gente discute lá, aprende, leva pra casa, às vezes discute também, ou passa pra uma outra pessoa; então não é uma coisa que fica fechada só entre eu e ele. Quando a gente passa pra outra pessoa, vai crescendo...

Pesquisadora: E pra quem vocês passaram essa experiência?

Adolescente do sexo feminino: Ah, a gente comenta com a minha mãe, né, fala pra elá como é que foi, com amigos meus, com o meu sobrinho... agora que ele foi, nesse que a gente foi [ela e o pai retornaram ao Interar-te pouco antes da entrevista, com o sobrinho dela de 5 anos]... a gente fala não só no fato que aconteceu... vira uma forma de tá junto, né, o dia-a-dia é muito corrido, corrido, corrido! A gente vai num sábado e passa junto um dia, aprendendo...

Adulto: Tem uma outra coisa, a pergunta foi pra ela, mas eu acrescento, a gente leva nossa peça, a gente produz lá, sai um produto do Interar-te e a gente leva nosso produto com orgulho 
[risos], a gente mostra, né, a gaveta da L. ficou lá um tempo em exposição na casa, a gente olhava prá ela... era artista... esse foi um passo no movimento da casa... (família 9)

Uma entrevistada ressaltou a aproximação à poética dos artistas, por ter participado de uma sessão do Interar-te ministrada por uma artista cujas obras estavam em exposição no Museu. Nessas sessões, chamadas de especiais, artistas contemporâneos são convidados a apresentar suas obras e ministrar uma oficina com as famílias. A entrevistada ainda demonstra que o programa oferece informações acerca dos processos de construção de trabalhos. Em seu depoimento, refere-se a uma instalação, realizada na exposição Mulheres Artistas: Relatos Culturais, pela paraguaia Paola Parcerisa.

Pesquisadora: E, pra você, como foi essa experiência de participar do Interar-te?

Adulta: As duas... as duas vezes que eu participei... as duas foram muito intensas: a primeira foi naquele momento, no ateliê, com a artista Beth Moysés... muito intenso porque a Beth realmente tem um trabalho que é um mergulho na intimidade, que nós fazemos assim como se fosse um pouco... um mergulho sem controle, sem limites. Toca muito, fala muito intimamente daquilo que nós temos - até, talvez, de mais reservado. Foi uma experiência muito valiosa. Na segunda ocasião também foi muito importante, porque havia uma questão de processo colocada, nós tivemos a possibilidade de fruir do processo da montagem da exposição, todo o grupo, um grupo de cerca de 20 pessoas. (família 11)

O estímulo do programa Interar-te à frequentação de museus foi outra informação colhida nos depoimentos. A entrevistada do agrupamento familiar 1 relatou: "Eles [as crianças] comentaram que gostaram muito, que queriam voltar outras vezes (...)". Lembramos o depoimento do pai dos dois meninos, um de 5 e um de 8 anos (família 4, citado à p.105), para quem participar do Interar-te representa "a satisfação e o compromisso de proporcionar esse contato... de arte... logo no começo da vida, na infância, antes da juventude".

Para a adolescente do agrupamento familiar 2, que reside com a família em uma cidade do interior do Estado de São Paulo, a vivência da arte no espaço físico do Museu é estimulante em si; ela declarou: “(...) não teve uma obra que mais me marcou, eu gostei do ambiente, assim, mais das pessoas diferentes."

A participação de toda família nas atividades programadas, das crianças aos adultos, foi comentada pela adulta da família 5, mãe de duas meninas, de 6 e 8 anos:

Pesquisadora: Você falou da importância da integração da família o tempo todo numa atividade. E você sentiu que isso realmente acontece? Porque esse é um objetivo do Interar-te. Você acha que, na prática, as atividades realmente proporcionam que os grupos convivam de uma forma interativa?

Adulta: Sim, eu acho que sim, proporcionou isso sim. Pelo menos dos grupos que eu participei, nas duas vezes eu vi que estavam todos envolvidos na atividade. Não foi aquela coisa... ah, é prá família, mas ficam as crianças ali fazendo e os pais tão só olhando... eles estavam participando, se interessando, gostando! Acho que tem, sim... (família 5) 
Complementando esse dado, uma outra entrevistada do agrupamento 9, mãe de um menino de 6 anos, comentou que, nas sessões do Interar-te, os adultos também aprendem.

Para a adulta da família 8, que levou alguns sobrinhos e o filho de uma funcionária a algumas das sessões do programa, a importância do contato com a arte na educação é importante:

Pesquisadora: E como foi, para você, participar com eles?

Adulta: Ah... foi gostoso, eu gostei muito, eu lembro que foi bom, tinha uma coisa... eu lembro muito da coisa de lembrar do pai, né, no Leon Ferrari, cuja a obra é "lembrança do meu pai", que eu gosto muito né, daquele trabalho. Eu gostei de como você trabalhou, Andrea, você resgatou a figura do pai... ali cada um pensou um pouco e falou sobre isso. Eu acho ótimo pôr a criança assim no contexto da arte... (por) que sai, sai um pouco desse... do trivial. Te põe numa outra situação, te põe numa situação inusitada, te põe pra pensar coisas que você não tinha pensado! Eu acho que a arte areja, sabe? Tira teias de aranha... assim... eu acho que faz pensar, eu acho muito interessante. Foi pra isso, foi pra levar os sobrinhos a sentirem um pouco... eu os levei muito à Pinacoteca também (...), e foi bacana (...) Eu acho que é para dar a oportunidade pra eles verem a vida por um outro prisma, eu acho que a arte faz isso. (família 8)

A aprendizagem de conteúdos relacionados a outras áreas não artísticas, no contexto das atividades programadas, foi apresentada no depoimento de outra entrevistada, mãe de um menino de 6 anos. Ela fala da mudança de comportamento do filho em relação a hábitos relacionados ao meio ambiente:

Pesquisadora: Pensando no que vocês vivenciaram juntos, há alguma coisa que você gostaria de relatar?

Adulta: Acho que... da... Barros, Renata Barros [referindo-se à sessão especial da exposição Poéticas da Natureza, ministrada pela artista]. Quando eles foram colher o lixo. Depois daquilo, meu filho nunca mais jogou coisa na rua. E, se ele vir alguém jogando, ele fala. Eu achei que marcou bastante aquilo... que ele achou... A gente chegou a ver peixe ali, no lago, e ele ficou muito... aquilo marcou bastante ele. (família 10)

Nessa oficina, a artista Renata Barros propôs aos participantes a representação de dois lagos sobre uma superfície plástica branca: um com resíduos não poluentes e outro com resíduos poluentes. Os materiais adicionados ao plástico foram coletados pelas famílias no próprio Parque Ibirapuera, em caminhada acompanhada pela artista e pela equipe de educadores do museu. Aos adultos, a artista solicitou a coleta dos resíduos poluentes. Brincou que era a geração deles que havia contribuído à degradação do planeta Terra. Às crianças e jovens, em contrapartida, solicitou a coleta dos resíduos naturais. Imagens dessa atividade foram apresentadas no capítulo de apresentação do programa Interar-te.

O casal da família 12 destaca a convivência em família e a contribuição das atividades do Interar-te ao desenvolvimento infantil:

Pesquisadora: Como foi, pra vocês, participar do Interar-te? O que fica dessa atividade?

Adulta: Da minha parte, eu acho que é um momento de uma convivência familiar em que a gente consegue uma concentração das crianças numa atividade que é interessante; que é, ao 
mesmo tempo, lúdica e que contribui muito pro desenvolvimento deles... a percepção, tudo isso (...)

Adulto: Ah, pra mim é interessante porque eu trago a família, de certa forma, pra esse mundo da arte que eu meio que vivo sozinho [o pai é artista em paralelo às atividades que desenvolve na área da Administração]. Então, é uma chance muito boa de colocar todo muito fazendo. É uma atividade muito prazerosa pra mim, porque eu envolvo todo mundo e... vou discutir essas questões que o artista faz sozinho no ateliê, né. Então, de repente, ali a gente é... é meio que uma brincadeira, né... mas, na brincadeira, a gente tá passando muitos conceitos. E eu acho que a convivência em si é muito importante, o fazer junto acho que dá uma coisa de família, de união, muito legal. (família 12)

As opiniões das crianças, a seguir, vêm acompanhas dos desenhos que lhes foram solicitados como técnica de apoio à entrevista. Foi pedido que representassem, com caneta hidrográfica, preferencialmente de uma só $\operatorname{cor}^{47}$, a experiência de sua participação no Interarte. As crianças foram orientadas a registrar algo importante para elas, tanto sobre o que tinham gostado como aquilo que não gostaram ao participarem do Interar-te. A solicitação do desenho foi feita terem visto imagens digitais ${ }^{48}$ dos momentos em que participaram do programa.

Foram entrevistadas 9 crianças com a utilização deste recurso. Quatro delas $(44,5 \%)$ discorreram sobre as oficinas realizadas no ateliê do Museu, narrando ou descrevendo etapas do processo de construção de seu trabalho pessoal no Interar-te. Três $(33,5 \%)$ destacaram o momento de visitação das obras no espaço expositivo e duas (22\%) comentaram ambas as etapas: contato com obras em exposição e atividades no ateliê do Museu.

Um menino de 8 anos inseriu situações imaginárias ao depoimento sobre a visitação a obras em exposição. O menino mora em uma cidade do interior onde não há museu de arte. Participa do programa Interar-te ao passar as férias com o pai, a madrasta e o irmão paterno, que residem em São Paulo. Para ele, a parte mais importante do programa Interar-te é a visita às obras na exposição e seu desenho possui personagens imaginários, como uma repórter, um cinegrafista e um fotógrafo registrando as obras - uma pintura e uma escultura - além dele e do irmão ${ }^{49}$.

\footnotetext{
${ }^{47}$ Solicitou-se que escolhessem apenas uma cor de caneta para que não se dispersassem colorindo o desenho, mas lhes foram disponibilizadas outras cores quando solicitaram.

${ }^{48}$ Imagens de autoria da pesquisadora para registro das sessões, autoavaliação, planejamento e relatórios.

${ }^{49}$ A presença da pesquisadora como educadora do Museu, quando da participação do menino no Interar-te, permite afirmar que a situação é imaginária.
} 

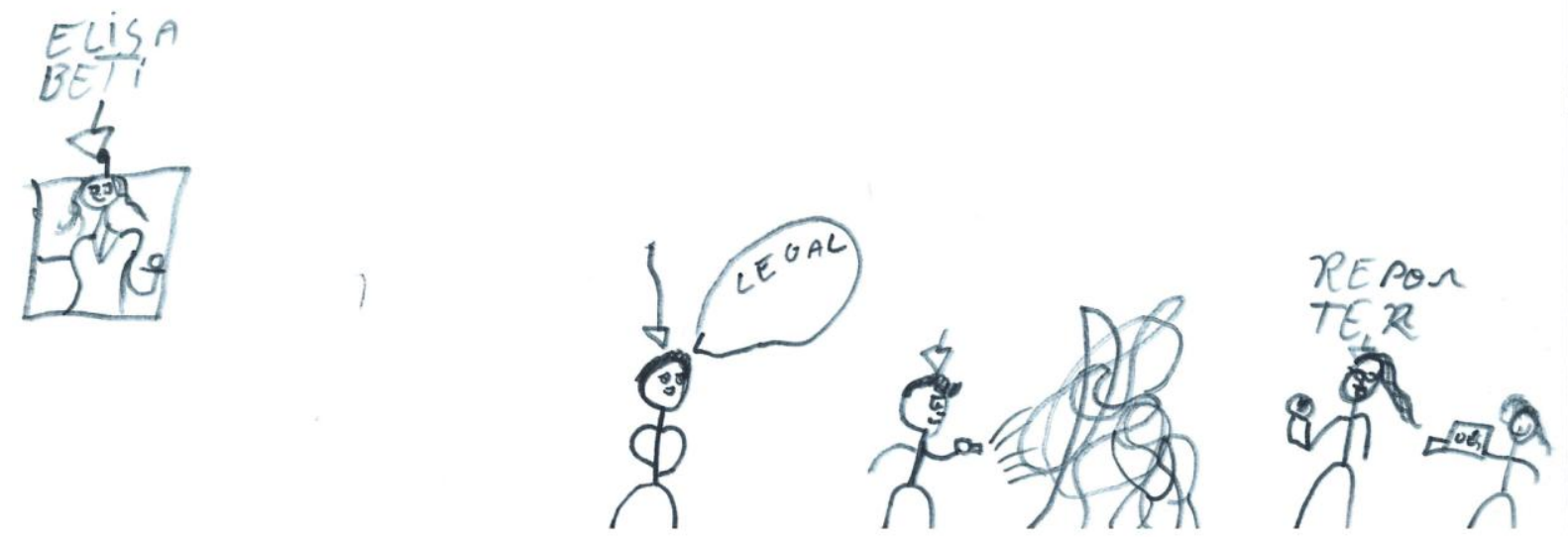

Figura 17: desenho de menino de 8 anos da família 4.

(menino) Tinha várias gentes vendo a obra. Tinha pessoa tirando foto. Tem uma repórter, um cara filmando.

(pesquisadora) Você os viu no museu?

(menino) Não.

(pesquisadora) Então por que você os desenhou?

(menino) Não sei.

(pesquisadora) E quem é a pessoa no quadro?

(menino) A Elizabete. É uma mulher que fica no quadro.

(pesquisadora) E o que você mais gosta quando vai ao museu, naquela atividade [Interar-te]?

(menino) O mais legal é ver as obras de arte.

(pesquisadora) E de qual você mais gostou?

(menino) Eu gostei das do espelho [refere-se às obras de Waldo Bravo, na exposição Cidades Imaginadas, onde imagens distorcidas eram vistas normalmente apenas por um espelho ao alto ou abaixo da imagem] (família 4 - menino de 8 anos. Depoimento colhido durante a realização do desenho.)

A socialização que a atividade proporciona, com a possibilidade de participação com amigos, foi apontada por uma menina de 11 anos. Ela ficou emocionada ao ver as amigas junto dela nas imagens digitais apresentadas pela pesquisadora. Seu desenho, também imaginário, representa-as no Museu. E, sobre ele, a menina comentou: "Eu fiz uma obra, a gente olhando. Eram quatro: eu, a Í., a I. e a J.”.

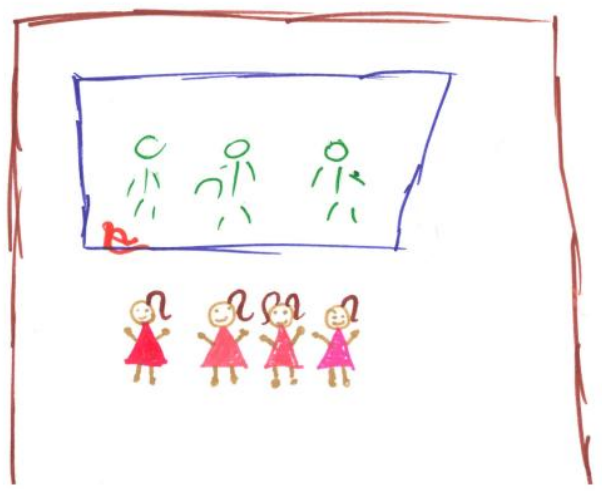

Figura 18: desenho de menina de 11 anos da família 1. 
Um menino de 6 anos comentou sobre algo de que não havia gostado durante a programação do Interar-te. Ele representou a si mesmo diante de esculturas em exposição e comentou: “Aqui, das esculturas, eu não gostei”.

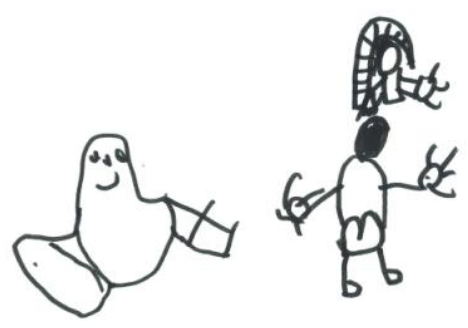

Figura 19: desenho de menino de 6 anos da família 5.

Depois, ao se ver nas imagens digitais da exposição, com sua família, relativizou a opinião negativa: falou que não havia gostado tanto dessa parte. A exposição a que se refere no desenho era de fotografias, não de esculturas, como consta de seu depoimento e da representação. Indagado sobre quais obras não havia gostado, aparentou não se lembrar, apenas completou: “(...) quer dizer, só de algumas” [não havia gostado]. Ou seja, preferiu a atividade prática no ateliê e o contato com a família, em detrimento da leitura das obras na exposição. A primeira participação desse garoto no programa foi com 2 anos e ele ia como acompanhante da irmã mais velha, que iniciou a participação aos 4 anos. Ela seguiu as atividades programadas, apesar da idade inferior à recomendada.

Durante a entrevista, o menino, então com 6 anos, realizou espontaneamente dois desenhos. No segundo, reproduzido abaixo, representou a si próprio com sua família e o produto de uma das oficinas: uma câmara escura, que propicia a visualização do ambiente através de uma imagem formada em uma superfície de papel vegetal. Como o processo de formação de imagem é através de um orifício, esta se forma invertida.

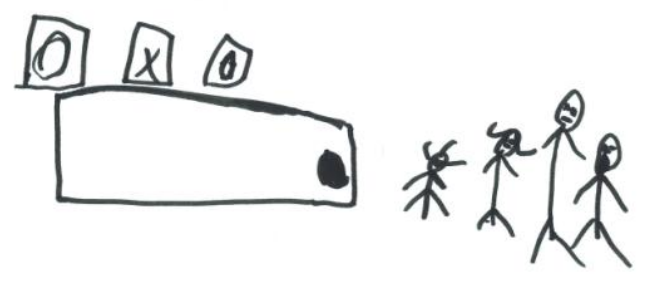

Figura 20: segundo desenho do menino de 6 anos da família 5. 
Sobre o desenho acima, ele comentou: "Eu gostei da câmera, dos quadros e da gente: eu, você [referindo-se à mãe], papai e S. [irmã]”.

Para outra criança de 6 anos, um menino da família 10, o mais marcante da participação no programa Interar-te foi a maceração de pigmentos para a produção de tintas. $\mathrm{Na}$ oficina, conduzida pelo artista Christophe Spoto no contexto das atividades da exposição Poéticas da Natureza, os familiares conheceram elementos compositivos de tintas, a origem de vários pigmentos e, depois, produziram tintas têmpera e aquarela.

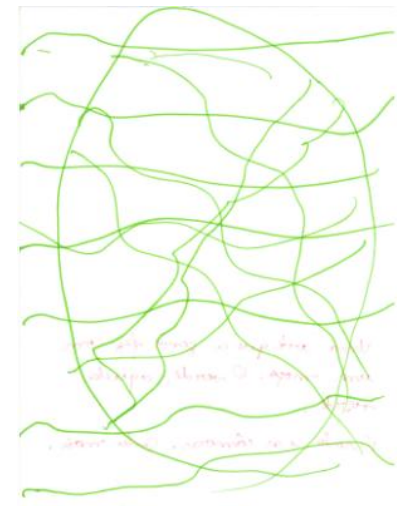

Figura 21: desenho do menino de 6 anos representando o gesto de macerar o pigmento verde.

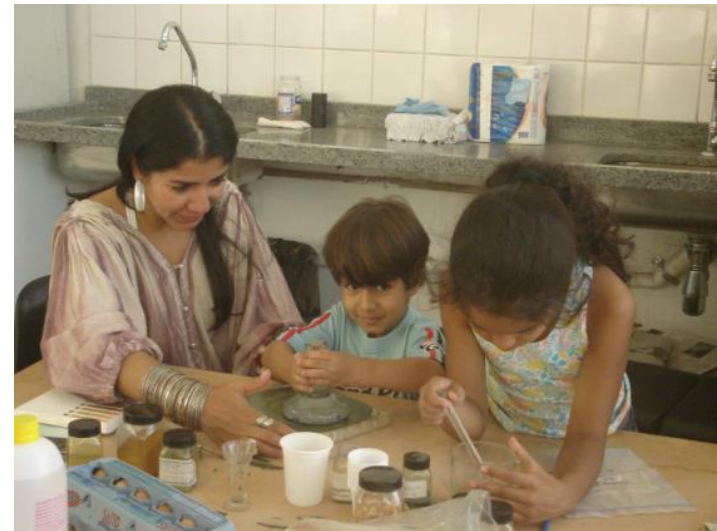

Figura 22: o menino, sua mãe e uma prima durante a ação representada no desenho.

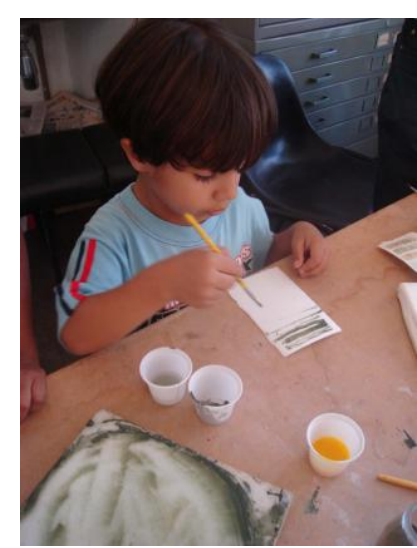

Figura 23: o menino, utilizando a tinta que ele preparou na oficina.

O desenho que o garoto fez durante a entrevista (imagem acima à esquerda) refere-se ao gesto de macerar o pigmento verde preparado por ele anos antes, na oficina ministrada por Spoto. Enquanto desenhava, o menino falou: "É uma arte que a gente fez com um moço. O verde, aquela verde...”. No centro, a foto registra o momento representado no desenho, em que a criança tritura o pigmento com um cadinho. À direta, o menino realiza um teste de intensidades diferentes da cor de tinta que ele preparou, por diluição (adição de água).

\section{PERGUNTA 3.4. Por QUE AS FAMÍLIAS VOLTARAM A PARTICIPAR DO INTERAR-TE? POR QUE NÃO} PARTICIPARAM MAIS VEZES? SE A ATIVIDADE FOSSE PAGA TERIAM PARTICIPADO?

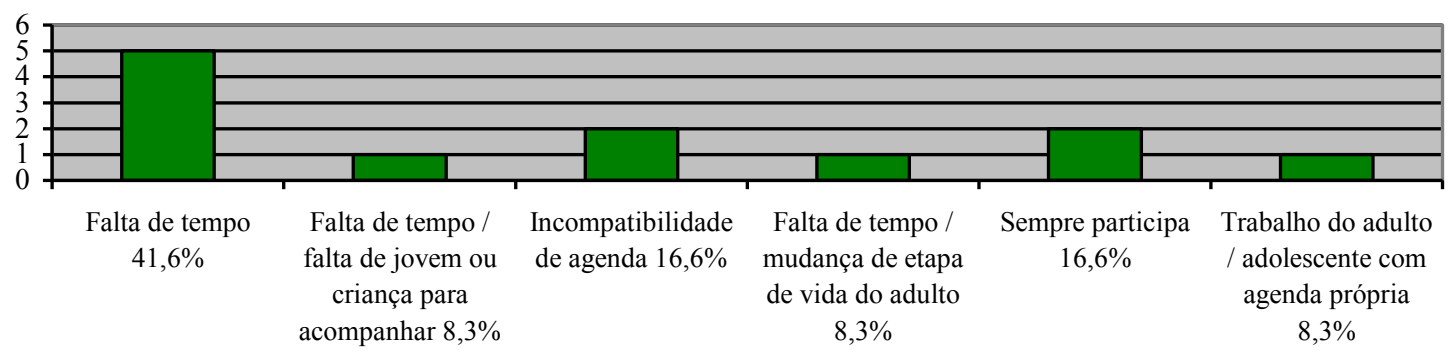

$\square$ número de famílias

Gráfico 37: Justificativa dos adultos das 12 famílias sobre não participar mais vezes do Interar-te. 
Pode-se observar diversos aspectos com as respostas dos adultos sobre a assiduidade nas atividades do programa Interar-te. Um deles é que o tempo de não-trabalho não corresponde ao "tempo livre", dado que ele é destinado às "obrigações paraprofissionais, familiares, religiosas e políticas”. (PUIG \& TRILLA, 2004, p.45)

Durante a entrevista, a adulta da família 8 comentou: "Eu gostaria de ir mais, mas é que, senão, você fica muito só por conta disso e tem aí, né, as questões da família”.

Além disso, podemos afirmar que as crianças iniciam uma agenda de programações sociais, com eventos como festas de aniversário de amigos, desde pequenas, o que compromete e influencia a dinâmica das atividades de lazer da família. O depoimento, do pai de duas crianças, de 5 e 8 anos (família 12) exemplifica isso: "Como eles têm uma vida social muito intensa, daí às vezes a gente tem umas brechas e consegue fazer alguma coisa, mas eles sempre têm alguma atividade, aniversário, então a gente fica por conta deles no fim de semana...".

Ao crescerem, na adolescência, a agenda é estendida aos compromissos exclusivamente com os amigos e à dinâmica de estudos pré-vestibulares. Uma adolescente de 17 anos, cursando o ensino médio, comentou sobre a falta justificando que as horas livres dos finais de semana são destinadas aos estudos e aos encontros com o namorado. Sua tia afirmou: “(...) falta de tempo... ela namora já... e prá quem namora nessa idade o final de semana é tudo o que eles têm, porque não têm muito tempo, eles estudam.” (família 6)

Para a mãe de uma participante de 13 anos, a rotina do jovem é diferente da rotina da infância:

\footnotetext{
Adulta: Eu acredito que eu voltei uma única vez e, depois, eu sinto muito não ter conseguido voltar outras vezes. Julgo que por algumas situações, porque aí eu... uma delas muito específica: eu leciono aos sábados agora, então isso me causa um impedimento. Mas eu diria... porque minha filha agora já é maior, porque esses finais de semana, de alguma maneira, ficam tomados ou pelos estudos ou por uma atividade que ela já tem na sua própria história de vida... e acho que, muito particularmente, porque eu leciono agora aos sábados. (família 11)
}

Ainda que se possa identificar semelhanças entre as rotinas infanto-juvenis dos entrevistados com as de qualquer outro jovem ou criança, lembramos que a amostra é restrita e não representa a diversidade de valores dos jovens de uma grande cidade como São Paulo. 


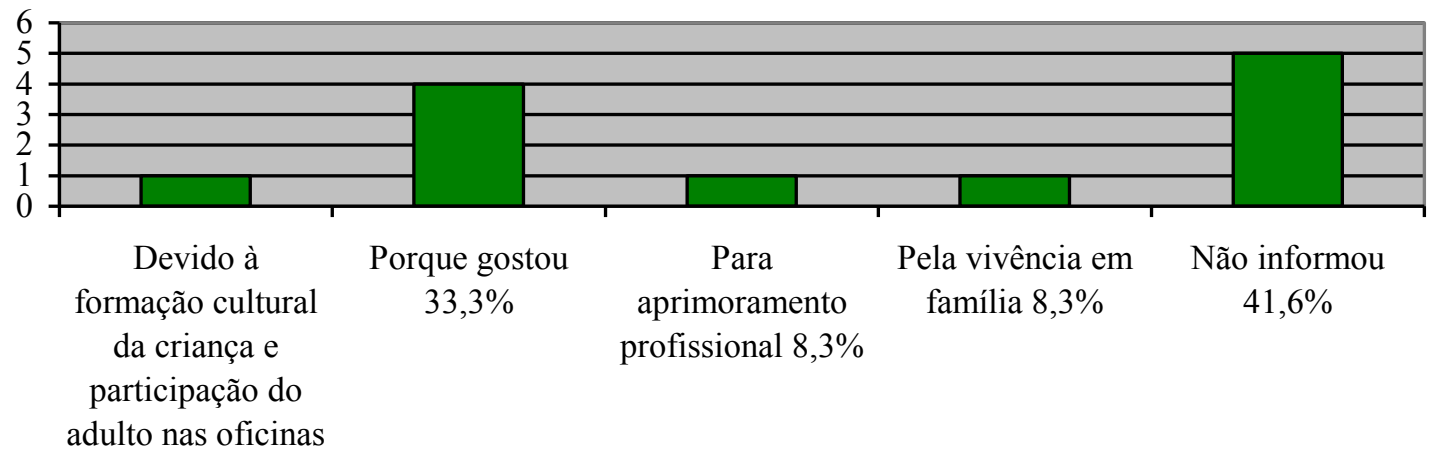

número de famílias

Gráfico 38: Justificativa das 12 famílias para a reincidência na participação no Interar-te.
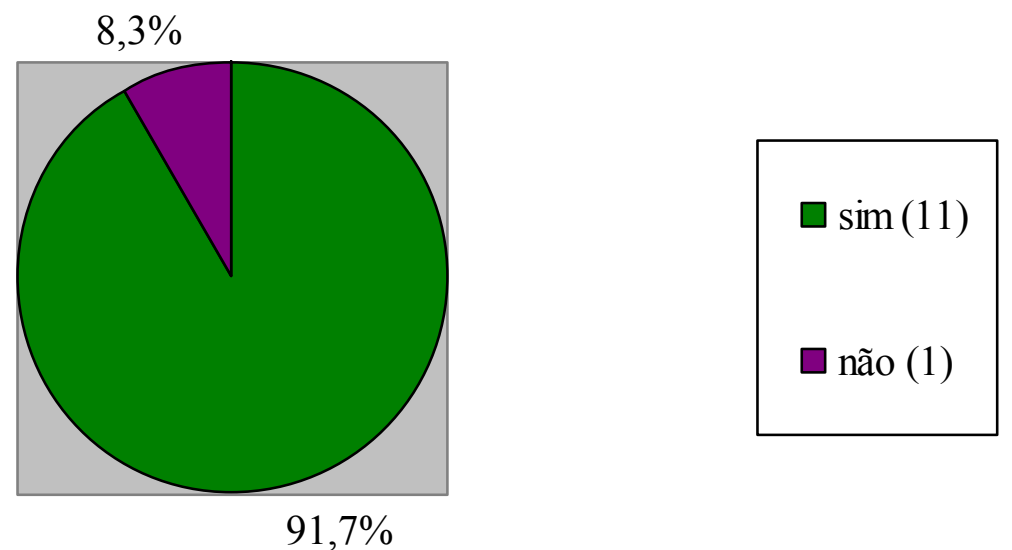

Gráfico 39: Famílias que indicaram o Interar-te para conhecidos.

* Porcentagem calculada considerando o universo de 12 famílias entrevistadas.

O fato de $91,7 \%$ dos entrevistados terem indicado a atividade demonstra satisfação por terem participado do Interar-te. A única entrevistada que declarou não ter indicado $(8,3 \%)$ explicou, em seu depoimento, que não conhece famílias com crianças ou jovens para indicar.

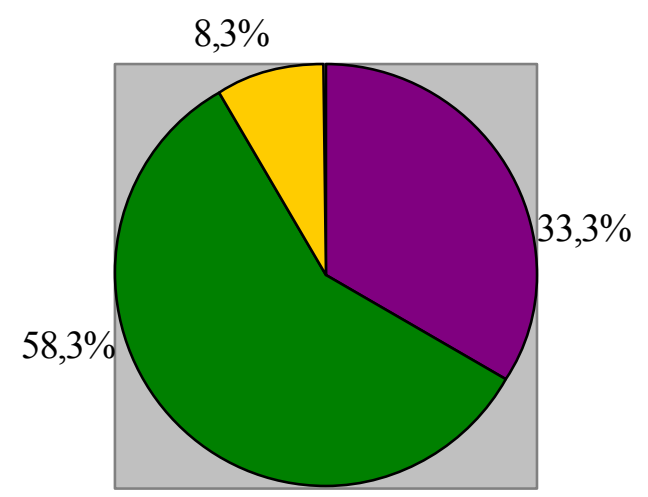

$\operatorname{sim}(4)$

$\square$ acho que $\operatorname{sim}(7)$

$\square$ não (1)

Gráfico 40: Indicação de participação no Interar-te caso a atividade não fosse gratuita.

* Porcentagem calculada considerando o universo de 12 famílias. 
Sete das 12 famílias $(58,3 \%)$, por intermédio de seus membros adultos, responderam "acho que sim" à sobre se frequentariam o Interar-te ainda que fosse pago. Duas dessas famílias justificaram a indecisão dizendo "depende do valor".

Das 4 famílias $(33,3 \%)$ que responderam que participariam mesmo se a atividade fosse paga, uma justificou dizendo que participa regularmente de outras atividades, inclusive pagas, fator que não representa um impedimento. Sabemos que cinema e teatro são pagos, com raras exceções, assim como vários museus na cidade de São Paulo cobram ingresso.

\section{PERGUNTA 3.5. O QUE AS FAMÍLIAS NÃO SABIAM SOBRE ARTE E APRENDERAM APÓS PARTICIPAREM DO INTERAR-TE?}

Esta questão foi elaborada para observarmos se os entrevistados consideram que a participação no Interar-te promove conhecimentos novos sobre artes visuais. Perguntar isso diretamente aos participantes poderia estimular respostas vagas, por isso optamos pela formulação de uma pergunta (Pergunta 3.5.) em que eles pudessem justificar a aprendizagem citando, por exemplo, os conteúdos aprendidos. Com isso, pudemos verificar se a aprendizagem citada referia-se às artes visuais. Para tabulação da informação prescindimos do conteúdo comentado; apontamos no quadro seguinte as respostas à questão aberta (3.5.) em que os entrevistados relataram ocorrência de aprendizagem, separando aquelas que referiram como aprendiz os adultos daquelas que referiram as crianças e jovens e, ainda, a ambos.

\begin{tabular}{|c|c|c|c|c|}
\hline & \multicolumn{4}{|c|}{ Aprenderam sobre artes visuais no Interar-te } \\
\hline & Adultos & Crianças e jovens & $\begin{array}{c}\text { Adultos, crianças e } \\
\text { jovens }\end{array}$ & $\begin{array}{l}\text { Resposta } \\
\text { indefinida }\end{array}$ \\
\hline Família 1 & & & $\mathrm{X}$ & \\
\hline Família 2 & & & $\mathrm{X}$ & \\
\hline Família 3 & & & $\mathrm{X}$ & \\
\hline Família 4 & & & $\mathrm{X}$ & \\
\hline Família 5 & & & $\mathrm{X}$ & \\
\hline Família 6 & & & $\mathrm{X}$ & \\
\hline Família 7 & & & & $\mathrm{X}$ \\
\hline Família 8 & & & $\mathrm{X}$ & \\
\hline Família 9 & & & $\mathrm{X}$ & \\
\hline Família 10 & & & $\mathrm{X}$ & \\
\hline Família 11 & & & & $X$ \\
\hline Família 12 & & & $\mathrm{X}$ & \\
\hline
\end{tabular}

Quadro 12: Indicação de aprendizagem sobre artes visuais pela família.

* Porcentagens abaixo calculadas considerando o universo de 12 famílias. 
Duas das 12 famílias $(16,7 \%)$ responderam positivamente sobre haver aprendizagem, porém não especificamente relacionada às artes visuais. Consideramos estas respostas indefinidas, pois houve aprendizagem mas não há como afirmar ter sido sobre artes visuais.

Dez das 12 famílias $(83,3 \%)$ entrevistadas reconhecem que o programa Interar-te promove conhecimento sobre artes visuais a toda a família. É importante terem declarado haver aprendizagem tanto para crianças quanto aos adultos, uma vez que um dos objetivos do programa é a integração das famílias. Ou seja, programações educativas que contemplem a aprendizagem de diferentes faixas etárias favorecem a troca de experiências e o deslocamento da relação cotidiana de parentesco ou de vínculos de amizade.

No depoimento de uma das adultas observamos não só a referência à aquisição de conhecimentos sobre artes visuais como, também, sobre as estratégias utilizadas nas abordagens dos conteúdos:

\footnotetext{
Pesquisadora: O que vocês não sabiam sobre arte e passaram a saber, depois de participar do Interar-te?

Adulta: Um pouco mais sobre arte contemporânea, com certeza, e também sobre artistas né, pontuais, que você colocou pra gente... falando desses artistas... mais especificamente sobre o artista e sobre arte contemporânea. Eu achei... bacana e também comecei a me interessar mais sobre o assunto.

Pesquisadora: Independentemente da questão artística, em específico, você gostaria de trazer alguma outra área, algum outro conhecimento novo percebido nesse programa?...

Adulta: Ah, eu gostei muito disso que eu já te falei, do jeito como você trouxe as coisas, né, como você coloca as questões... de uma forma bastante didática, né, bastante... oportuna. E a questão didática, como professora, pegando como você dá aula, assim, essa questão didática, pra mim foi fundamental também. Ver e também conhecer como, aqui no Brasil, a gente tem também bons programas, programas de arte tipo esse.. (família 3 )
}

\section{PERGUNTA 3.6 O QUE AS FAMÍLIAS FIZERAM NO DIA EM QUE PARTICIPARAM DO INTERAR-TE,} ANTES OU DEPOIS DA ATIVIDADE?

Esta questão foi inserida na entrevista para observarmos se o fato de a atividade educativa ocorrer na sede do MAC USP em um parque, o Parque Ibirapuera, favorece a participação do público. O público pode usufruir, antes ou depois do Interar-te, das demais programações das diversas instituições que o parque abriga - assim como dos parques infantis, da infraestrutura para piqueniques e das áreas verdes. 


\begin{tabular}{|l|c|c|c|}
\hline $\begin{array}{c}\text { Nos dias em que frequentou o } \\
\text { Interar-te, a família realizou: }\end{array}$ & $\begin{array}{c}\text { Outras atividades } \\
\text { dentro do Parque }\end{array}$ & $\begin{array}{c}\text { Outras atividades } \\
\text { fora do Parque }\end{array}$ & $\begin{array}{c}\text { Nada diferente } \\
\text { da rotina }\end{array}$ \\
\hline Família & $\mathrm{X}$ & $\mathrm{X}$ & \\
\hline Família 1 & & $\mathrm{X}$ & $\mathrm{X}$ \\
\hline Família 2 & $\mathrm{X}$ & & \\
\hline Familia 3 & $\mathrm{X}$ & $\mathrm{X}$ & \\
\hline Família 4 & $\mathrm{X}$ & $\mathrm{X}$ & \\
\hline Família 5 & $\mathrm{X}$ & $\mathrm{X}$ & \\
\hline Familia 6 & & $\mathrm{X}$ & \\
\hline Família 7 & $\mathrm{X}$ & $\mathrm{X}$ & \\
\hline Família 8 & $\mathrm{X}$ & $\mathrm{X}$ & \\
\hline Família 9 & & $\mathrm{X}$ & \\
\hline Familia 10 & & & \\
\hline Família 11 & & & \\
\hline
\end{tabular}

Quadro 13: Indicação de programações da família além do Interar-te nos dias que o frequentaram. Houve indicação de mais de um fator por família.

* Porcentagem abaixo calculadas considerando o universo de 12 famílias.

Para 8 das 12 famílias (66,7\%) o espaço do parque foi aproveitado para a prática de outras atividades de lazer em uma das participações ao programa Interar-te, antes ou depois da ida ao Museu. Para 4 das 12 famílias $(33,3 \%)$ houve a prática de outra atividade de lazer dentro do parque em todas as vezes que participaram do Interar-te.

Sobre o tipo de atividades realizadas, além da participação no Interar-te (às quais não nos deteremos, dado não ser o objetivo da questão), foram destacados: refeições (almoço, jantar, lanche e tomar sorvete), frequentação a outros museus de arte, brincadeiras nos parques infantis e andar de bicicleta.

Falk e Dierking (2011, p.43) apontam que "families came to the zoo with a range of social agendas, such as spending time together or sharing a meal, that were as important as viewing the exhibits". Ou seja, podemos dizer que a programação de lazer das famílias favorece a sociabilização e a convivência. 


\section{CONSIDERAÇÕES FINAIS}

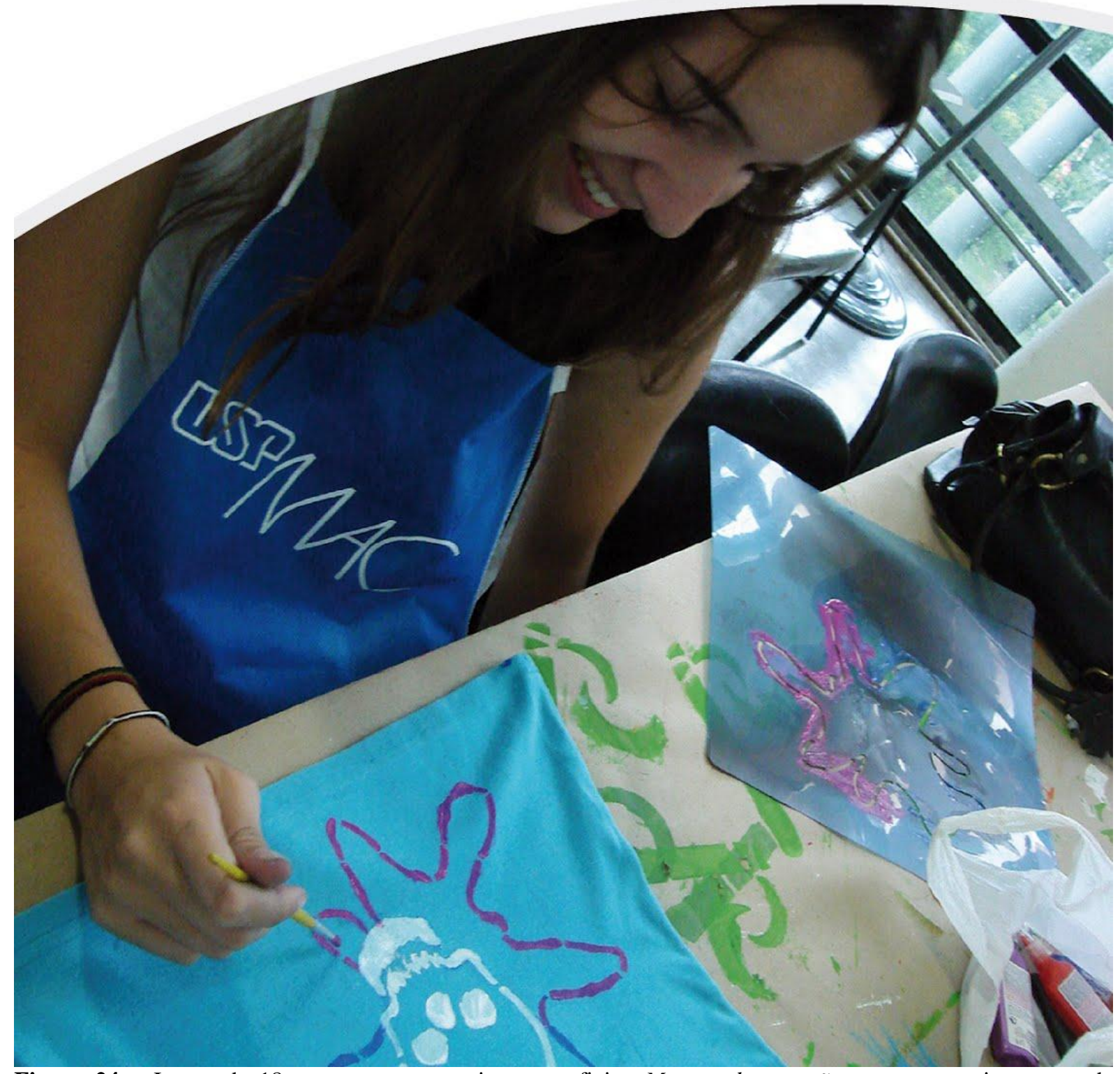

Figura 24 - Jovem de 18 anos estampa camiseta na oficina Marcas de gerações como parte integrante da programação do Interar-te para a exposição Street art - dos grafitos à pintura, em janeiro de 2008. 


\section{CONSIDERAÇÕES FINAIS}

Os dados obtidos na pesquisa demonstram que os adultos entrevistados são os responsáveis pela formação de hábito de frequentação de museus e instituições culturais das crianças e jovens de suas famílias. Os adultos frequentam mais estas instituições nos momentos do lazer em família do que no lazer pessoal e as crianças e jovens vão mais a museus de arte com familiares do que com a escola.

As motivações que levam os adultos a frequentarem exposições de artes visuais com a família atual não são diretamente relacionadas à criação de hábitos de frequentação de museus e instituições culturais com a família de origem, entretanto pode-se afirmar que estão relacionadas a hábitos de contato e frequentação a outras atividades artístico-culturais adquiridos com a família de origem.

Por outro lado, cresceu o número de ações educativas atreladas a exposições na cidade de São Paulo nas duas últimas décadas. E esse aumento da oferta implicou num aumento da variedade de ações, atendendo diferentes faixas etárias. Os familiares estudados nessa pesquisa informaram que procuram o programa Interar-te em busca de conhecimento e de investimento na criação de hábitos de frequentação de museus para suas crianças e adolescentes. Ressaltamos que os adultos entrevistados representam uma pequena parcela da população da cidade de São Paulo e fazem parte das classes econômicas A e B. Para a amostra, valores como educação e cultura são prioridades e questões financeiras como o custo indireto para participarem da programação educativa num museu - deslocamento e alimentação, por exemplo -, não os impedem de participar.

Constatou-se que os entrevistados procuraram o programa educativo Interar-te, do MAC USP mais de uma vez por considerarem que este promove ensino e aprendizagem em artes visuais às diferentes faixas etárias, assim como a integração entre os membros, da família.

Ao mesmo tempo que respondia aos problemas que a motivaram, a pesquisa suscitou novos questionamentos sobre o público frequentador do programa educativo estudado, dentre os quais são relevantes:

1. Por que $82,5 \%$ das famílias participantes da programação, no período entre 2006 e 2010, não retornaram a participar do Interar-te? Elas participaram de atividades culturais em outras instituições?

2. Qual a classificação econômica das famílias que não retornaram? Este é um fator decisivo ou esta questão está relacionada a valores sobre educação? As famílias 
que não retornaram procuraram outras atividades educativas em instituições culturais ou optaram por direcionar as despesas com lazer para atividades relacionadas à indústria do entretenimento $?^{50}$

3. Como descentralizar as ações dos museus, tornando-os mais próximos da população de periferia de uma grande cidade como São Paulo? Ainda, como levar o contato direto com as artes visuais à população destas áreas $?^{51}$ Como promover esta interação de modo não "etnocêntrico"? É possível?

Novas investigações e pesquisas poderão ser desenvolvidas no âmbito do trabalho desenvolvido na Divisão Técnico-Científica de Educação e Arte do MAC USP. Estas novas questões tocam a pesquisadora na condição de educadora idealizadora e responsável pelo programa educativo Interar-te. A reflexão a seguir busca relacionar a experiência e os resultados da pesquisa à prática profissional no programa do setor educativo investigado.

\subsection{Expansão do alcance do programa educativo}

Após ter me apresentado como educadora de artes visuais (Antes do antes, p.11), tomo a liberdade de escrever sobre o depois, sobre o trabalho no Interar-te com a conclusão desta experiência acadêmica.

Os resultados apontam para a possibilidade de se atingir mais famílias e esse é um objetivo que se impõe como consequência dessa pesquisa. Uma possibilidade é que o Interarte seja oferecido aos domingos, por exemplo. Minha expectativa com isso é que o grande volume de público do Parque Ibirapuera, notadamente não frequentador do parque nos demais dias da semana, poderia participar desse programa educativo no Museu.

A construção da pesquisa também levou a um questionamento sobre quem sou como educadora, qual a origem de minha experiência com arte e de minha trajetória profissional desde a formação acadêmica. Essa arte institucionalizada que para mim é significativa, é importante para todos? No entanto, os outros estão realmente desprovidos do contato com as

\footnotetext{
${ }^{50}$ Esclarecemos que as atividades de entretenimento não são entendidas aqui como algo que deva ser evitado. O que se questiona é se as famílias buscam um equilíbrio entre atividades culturais e as estritamente de entretenimento. Além disso, na condição de escolha das pessoas: estão elas optando por esta ou aquela atividade de lazer cientes dos valores que estão reproduzindo ou por falta de opções, de vivência e de educação para o consumo?

${ }^{51} \mathrm{O}$ conhecimento aprofundado de ações nesse sentido se faz atual e necessário. Há experiências, como o programa Lá Vai Maria (Centro Universitário Maria Antônia da USP, a programação Bienal na Cidade (29a Bienal de São Paulo), que exibiu vídeos presentes na mostra em outras instituições da cidade e na região metropolitana, e a ação da artista Mônica Nador à frente do JAMAC (Jardim Miriam Arte Clube). Edições do evento Arte/Cidade, mesmo realizadas em bairros centrais de São Paulo, também podem ser citadas.
} 
artes visuais? Qual é a experiência artística e estética desses a quem chamo de outros? Que podemos dizer sobre sua educação cultural?

As inquietações trazidas por esta experiência acadêmica são mobilizadoras e instigantes. Em busca de elucidar este estado de reflexão, concluo este trabalho citando o final do poema O fim do mundo, de João Cabral de Melo Neto (1994, p.71): "Em vez de juízo final a mim me preocupa o sonho final". Explico: como no relato do pai entrevistado da família 9, também acredito que deveríamos ter mais contato com a arte, onde quer que ela esteja.

(...) nós tivemos uma oportunidade em família de visitar os grandes museus do mundo, então nós tivemos lá uma curiosidade, uma aventura, pegamos uma mochila e... vamos ver de perto! E o museu era como se fosse o ponto de referência, não era chegar no país, era chegar no museu. Então, quando chega lá no Louvre, por exemplo, a gente chegou e pronto, chegamos, sem muito conhecimento, sem muita qualidade de ver as obras específicas, que cada obra é um poder danado, né? A gente via as obras mas a nossa sacada, a nossa vitória, nosso podium era ter chegado ao museu. Então acho que a gente é muito apegado, nós temos muitas histórias com museus, acho que todos nós deveríamos ter mais história com museu. [família 09]

É desejável que as pessoas usufruam dos museus de arte com experiências de qualidade e não de consumismo cultural (BAUMAN, 2008), que os visitem como ao museu imaginário de Marcelo Araújo: “(...) o museu ideal e utópico, para mim, é o museu que se tornasse tão vital e importante para as pessoas que elas passariam a ter com ele uma relação tão essencial e cotidiana como se entrassem em um supermercado, em uma farmácia ou em um cinema". (GROSSMANN \& MARIOTTI, 2011, p.142)

Concluindo, a educação em arte nos museus e instituições culturais pode contribuir à educação visual e cultural das pessoas expandindo o repertório artístico e garantindo acesso aos bens culturais. 


\section{REFERÊNCIAS BIBLIOGRÁFICAS}

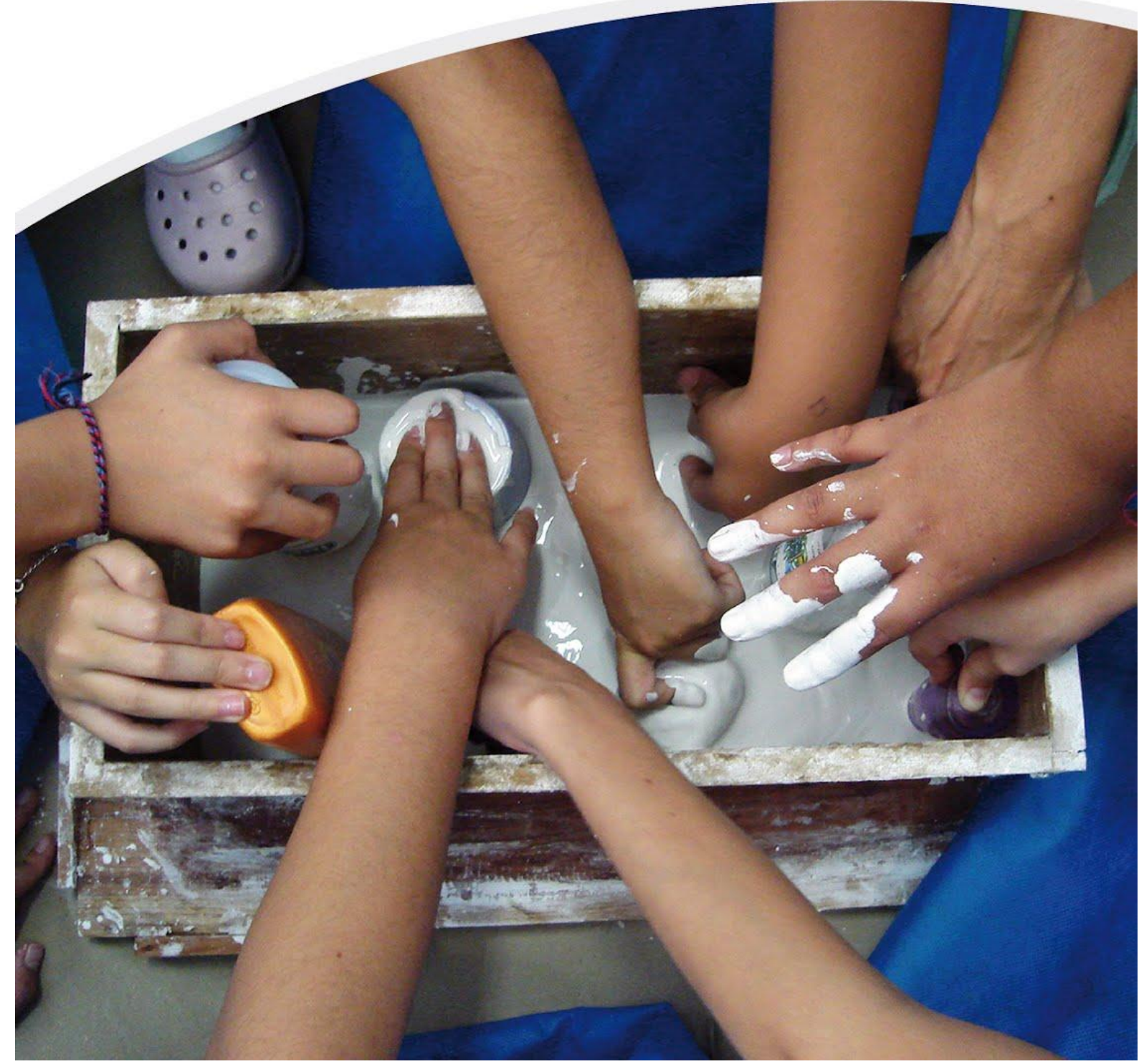

Figura 25 - Participantes da oficina especial com a artista Paola Parcerisa na exposição Mulheres artistas: relatos culturais, em março de 2008. Nessa edição, o público confeccionou peças que foram utilizadas na obra, que estava em construção. Essa foi a única sessão do Interar-te ocorrida antes da abertura de uma exposição, na qual os participantes puderam ver e acompanhar a montagem de obras no espaço expositivo. 


\section{REFERÊNCIAS BIBLIOGRÁFICAS}

ANDRÉ, M.E.D.A. de. Etnografia na prática escolar. São Paulo: Papirus Editora, 1995.

Estudo de caso em pesquisa e avaliação educacional. Brasília: Líber Livro, 2005.

BARBOSA, A.M. A imagem no ensino da arte: anos oitenta e novos tempos. São Paulo: Perspectiva, 2005.

BARDin, L. Análise de Conteúdo. Tradução Luís Antero Reto; Augusto Pinheiro. Lisboa, Edições 70, 1977.

BAUMAN, Z. Vida para consumo: a transformação das pessoas em mercadoria. Rio de Janeiro: Zahar, 2008.

BLEGER, J. Temas de psicologia: entrevista e grupos. 4.ed. São Paulo: Martins Fontes, 1989. (Coleção Psicologia e Pedagogia)

BORDIEU, P. (Org.). A miséria do mundo. 7.ed. Petrópolis: Vozes, 2008.

BOTT, E. Família e rede social. Rio de Janeiro: Francisco Alves, 1976.

BROUGÈRE. G. Brinquedos e companhia. São Paulo: Cortez, 2004.

COELHO, T. Dicionário crítico de política cultural. 2.ed. São Paulo: Iluminuras, 1999.

COLI, J. O que é arte? 11.ed. São Paulo: Brasiliense, 1990.

COLOMBINI, Luis. Aprendi com meu pai. São Paulo: Versar, 2006.

CSIKSZENTMIHALYI, M. A descoberta do fluxo: a psicologia do envolvimento com a vida cotidiana. Rio de Janeiro: Rocco, 1999.

DELVAL, J. Introdução à prática do método clínico: descobrindo o pensamento das crianças. Porto Alegre: Artmed, 2002.

DEWEY, J. Art as experience. New York: The Berkley Publishing Group, 2005.

DIAS, J.A.B.F. Algumas considerações antropológicas sobre o ensino artístico. Revista Gávea, Rio de Janeiro, n.11, p. 195-201, abr. 1994.

DUMAZEDIER, I. et al. Ocio y sociedad de classes. Barcelona, Fontanella, 1971.

FALK, J.H.; DIERKING, L.D. The Museum Experience. Walnut Creek, CA, USA: Left Coast Press, 2011.

FERNANDES, D. Avaliar para aprender: fundamentos, práticas e políticas. São Paulo: Editora UNESP, 2009.

FRANCO, M.L.P.B. Análise de Conteúdo. 3.ed. Brasília: Liber Livro Editora, 2008.

GADOTTI, M. A escola na cidade que educa. Cadernos CENPEC: Educação, Cultura e

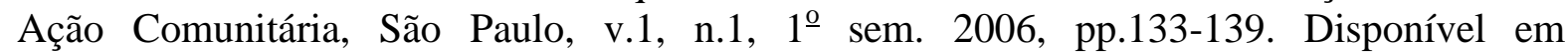
$<$ http://cenpec.org.br/biblioteca/educacao/producoes-cenpec/cadernos-cenpec-n-1-educacaoe-cidade>. Acesso em: 05 out. 2008.

GADOTTI, M.; PADILHA, P. R.; CABEZUDO, A. (Orgs.). Cidade educadora: princípios e experiências. São Paulo: Cortez/Instituto Paulo Freire; Buenos Aires: Ciudades Educadoras America Latina, 2004.

GÓMES, G.R. Metodologia de la investigación cualitativa. Málaga: Aljibe, 1999.

GONZAGA, A.M. A pesquisa em educação: um desenho metodológico centrado na abordagem qualitativa. In: PIMENTA, S.G.; GHEDIN, E.; FRANCO, M.A.S. (Orgs.). Pesquisa em educação: alternativas investigativas com objetos complexos. São Paulo: Loyola, 2006. 
GRINSPUM, D. Educação para o patrimônio: museu de arte e escola - responsabilidade compartilhada na formação de públicos. 2000. Tese (doutorado) - Faculdade de Educação, Universidade de São Paulo, São Paulo, 2000.

GROSSMANN, M. O que é o MAC: catálogo. [São Paulo]: Universidade de São Paulo, Museu de Arte Contemporânea, [1986]. Catálogo de exposição.

GROSSMANN, M. Interação entre Arte Contemporânea e Arte-Educação: subsídios para a reflexão e atualização das metodologias aplicadas. 1988. Dissertação (mestrado) - Escola de Comunicações e Artes, Universidade de São Paulo, São Paulo, 1988.

GROSSMANN, M.; MARIOTTI, G. (Orgs.). Museum art today: Museu arte hoje. São Paulo: Hedra, 2011.

IAVELBERG, R. O desenho cultivado da criança: prática e formação de educadores. Porto Alegre: Zouk, 2006.

KANT, I. Resposta à pergunta: Que é "Esclarecimento"?. In: KANT, I. Textos seletos. Petrópolis: Vozes, 1974.

KEHL, M.R. O tempo e o cão: a atualidade das depressões. São Paulo: Boitempo, 2009.

KISHIMOTO, T. Brincadeiras para crianças de todo o mundo. São Paulo: UNESCO, 2007.

LAFARGUE, P. O direito à preguiça. São Paulo: Editora UNESP/Hucitec, 2000.

LEITE, M.I.; OSTETTO, L.E. (Orgs.). Museu, educação e cultura: encontros de crianças e professores com a arte. Campinas: Papirus, 2005.

LÉVI-STRAUSS, C. As estruturas elementares do parentesco. 4.ed. Petrópolis: Vozes, 2008.

MELO NETO, João Cabral de. Obra completa: volume único. Rio de Janeiro: Nova Aguilar, 1994.

MOURA, M.L.S.; FERREIRA, M.C. Projetos de pesquisa: elaboração, redação e apresentação. Rio de Janeiro: EDUERJ, 2005.

NICHOLS, M.P.; SCHWARTZ, R.C. Terapia familiar: conceitos e métodos. 3.ed. Porto Alegre: Artmed, 1998.

PERROTTI, E. Confinamento cultural, infância e leitura. São Paulo: Summus, 1990.

PIMENTA, S.G.; GHEDIN, E.; FRANCO, M.A.S. (Orgs.). Pesquisa em educação: alternativas investigativas com objetos complexos. São Paulo: Loyola, 2006.

PUIG, J.M.; TRILLA, J. A pedagogia do ócio. 2.ed. Porto Alegre: Artmed, 2004.

QUINTANA, M. Para viver com poesia. Seleção e organização: Márcio Vassallo. São Paulo: Globo, 2007.

ROMANELLI, G. Famílias de camadas médias: a trajetória da modernidade. 1986. Tese (doutorado) - Departamento de Ciências Sociais/FFLCH, Universidade de São Paulo, 1986.

SARTI, C.A. A família como espelho: um estudo sobre a moral dos pobres. 5.ed. São Paulo: Cortez, 2009.

TOJAL, A.P.F. Museu de arte e públicos especiais. 1999. Dissertação (mestrado) - Escola de Comunicações e Artes, Universidade de São Paulo, São Paulo, 1999.

VYGOTSKY, L.; LEONTIEV, A.; LÚRIA, A. El proceso de formación de la psicologia marxista. Moscú: Editorial Progreso, 1989.

WORTHEN, B.R.; SANDERS, J.R.; FITZPATRICK, J.L. Avaliação de programas: concepções e práticas. São Paulo: Gente, 2004.

ZANINI, W. A Expressão Plástica da Criança Excepcional: catálogo. [São Paulo]: Universidade de São Paulo, Museu de Arte Contemporânea, [1972]. Catálogo de exposição. 


\section{APÊNDICES}

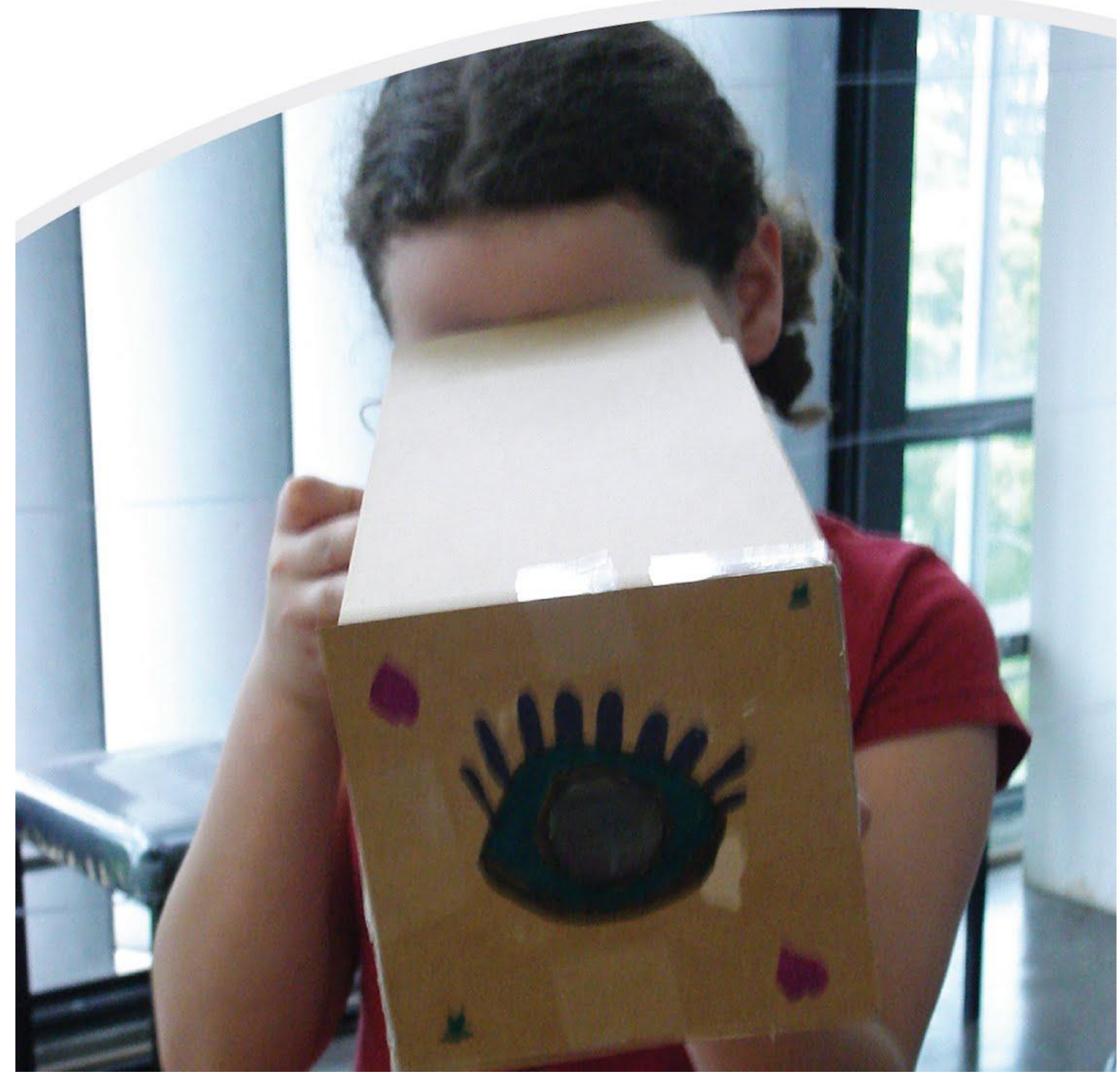

Figura 26 - Criança explora a câmera escura que construiu na oficina Vendo o mundo de ponta-cabeça durante oficina do Interar-te na exposição Fotógrafos da vida moderna, em setembro de 2008. 


\section{Apêndices}

\section{Apêndice 1 - Entrevista semiestruturada aos agrupamentos familiares}

\section{1 - Entrevista dirigida ao grupo familiar}

Família

Participaram do Interar-te

vezes, em

Idade dos participantes infanto-juvenis:

quando participaram

na entrevista

Quem mora na mesma casa?

Quem convive/trabalha na casa, fazendo parte da rotina?

Quais as atividades de trabalho da família (remunerada ou não)?

Qual a escolarização dos pais?

Onde moram? (bairro/cidade)

Onde estudam os menores?

Que meio de transporte utilizam para ir ao Interar-te?

Antes da entrevista, apresentar as imagens dos participantes durante as atividades no MAC USP, no intuito de aproximar o grupo do objeto de estudo.

CRIANÇA / JOVEM (tipo de vínculo: _amizade /_ familiar:

1. Já foram a exposições de arte com a escola? Foi igual ou diferente desta visita com os pais? Explique.

2. Vocês lembram de uma exposição de arte que mais gostaram? Por quê?

3. Se pudesse escolher uma palavra para representar a experiência de participar do Interar-te, qual seria?

4. Entre as atividades abaixo, quais você prefere fazer com seus pais? Por quê?
a. Assistir um filme; ir ao cinema?
b. Ouvir música; ir a um show?
c. Ir a uma exposição?
d. Outros:

ADULTO

1. Quais suas atividades de lazer? Quem o/a acompanha? Quem as escolhe?

2. Compram livros, apresentam músicas e filmes aos filhos? Acompanham os que eles conhecem? (não necessariamente precisam assistir na íntegra)

3. Quando a escola dos seus filhos realiza atividade cultural extra classe, o que você acha? Incentiva? Busca saber onde é? Conversa sobre esta experiência depois?

4. Quem acompanha seus filhos nas atividades de lazer?

5. Na sua opinião, o que desenvolve o gosto pela cultura?

6. Descreva o que você faz para valorizar a cultura da família.

7. Como a arte entrou na sua vida? Como foi sua experiência com arte na infância e na adolescência, na escola e fora dela?

8. Quem influenciou seu gosto por arte? Como/quais eram as atividades de lazer em sua infância e juventude? Qual a participação de seus pais? Mais alguém cumpria este papel? Quem? Como?

9. Sobre o programa Interar-te: por que proporcionar esta experiência aos seus filhos?

10. Se a atividade fosse paga, você teria participado? 


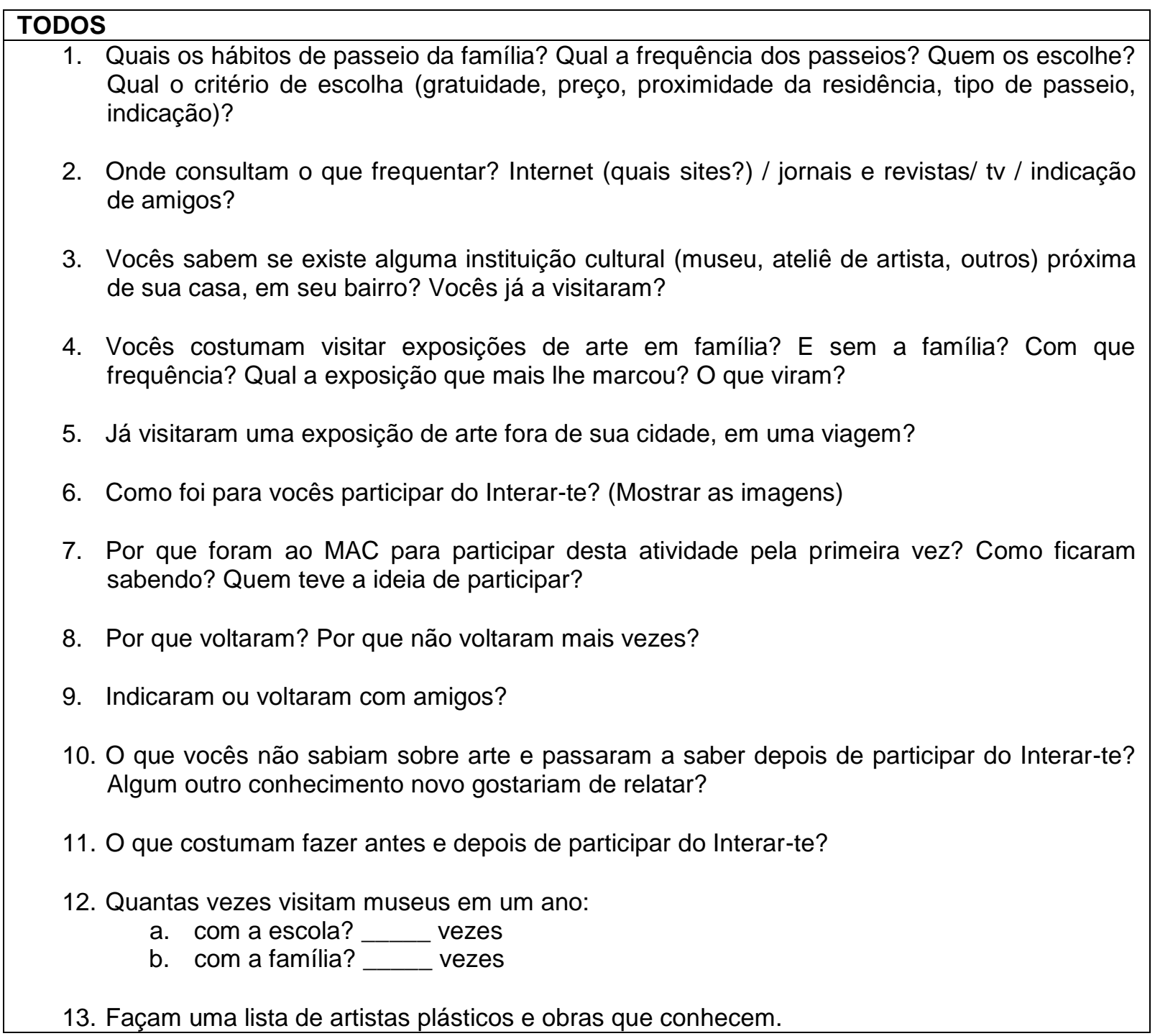




\section{2 - Desenhos solicitados às crianças como instrumento de apoio $\mathrm{e}$ comentários da pesquisadora}

Quadro - Respostas das crianças entrevistadas (05 a 11 anos) quando solicitado que fizessem um desenho (instrumento de apoio à entrevista) que representasse a experiência de participação no programa Interar-te: algo importante, sobre o que tivessem gostado ou não.

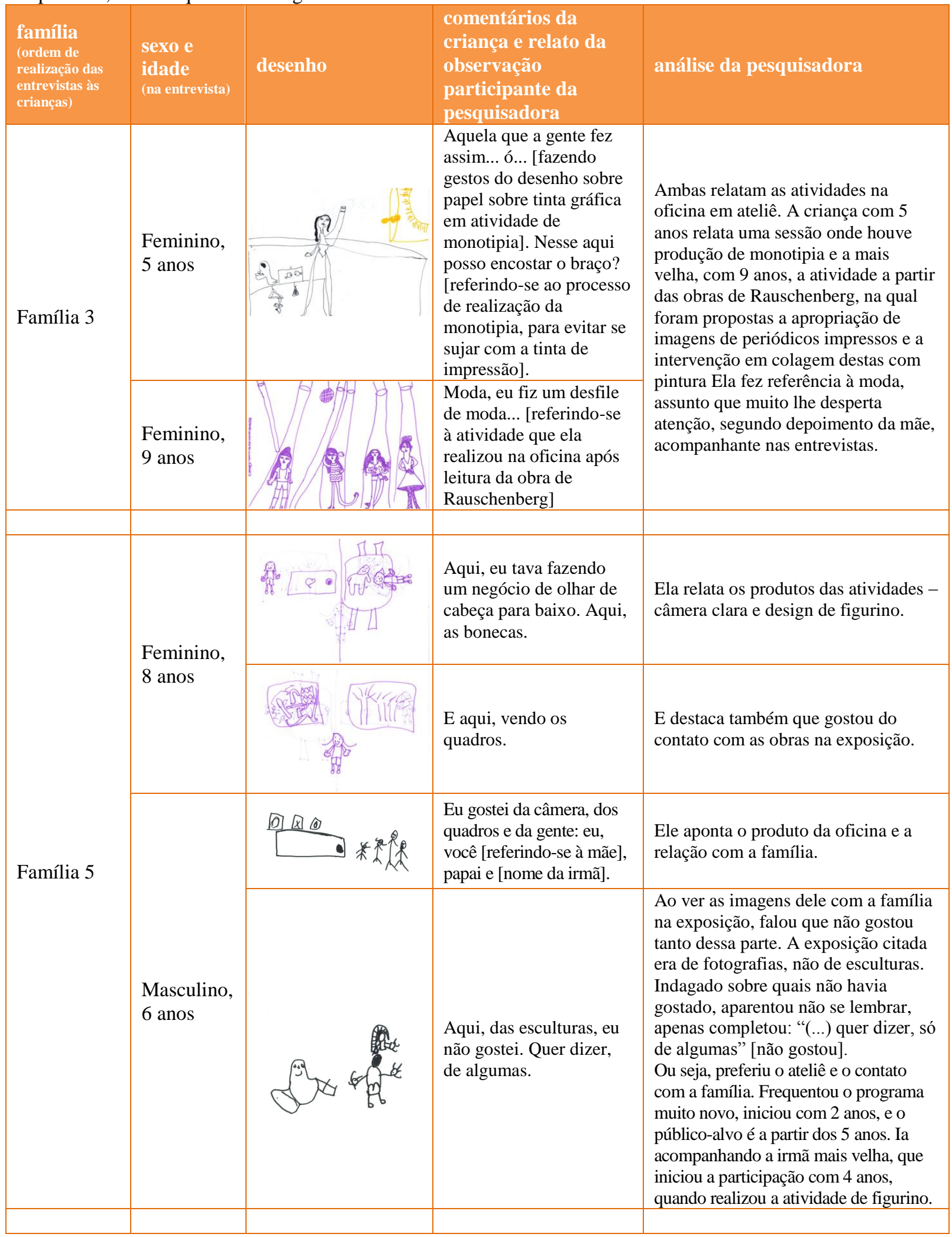




\begin{tabular}{|c|c|c|c|c|}
\hline Família 10 & $\begin{array}{l}\text { Masculino, } \\
6 \text { anos }\end{array}$ & & $\begin{array}{l}\text { É uma arte que a gente } \\
\text { fez com um moço. O } \\
\text { verde, aquela verde. }\end{array}$ & $\begin{array}{l}\text { O desenho refere-se ao gesto de } \\
\text { macerar pigmento verde, preparado } \\
\text { por ele anos antes em oficina de } \\
\text { preparo de tintas (têmpera e aquarela) } \\
\text { ministrada pelo artista, autor da obra } \\
\text { vista na exposição. }\end{array}$ \\
\hline & $\begin{array}{l}\text { Masculino, } \\
5 \text { anos }\end{array}$ & a & $\begin{array}{l}\text { Eu tô fazendo eu pisando } \\
\text { naquele botãozinho } \\
\text { vermelho que faz a } \\
\text { máquina mexer. Eu não sei } \\
\text { fazer a máquina. [Que cor } \\
\text { era a máquina?] Colorida. } \\
\text { [É mesmo?] Não, era preta. } \\
\text { Eu vou fazer o contorno de } \\
\text { preto. [E, antes, coloriu o } \\
\text { desenho brincando com as } \\
\text { canetas, segurando três na } \\
\text { mão para fazer linhas e } \\
\text { pontos de várias cores ao } \\
\text { mesmo tempo]. Ah, tinha } \\
\text { duas dela.... um pouquinho } \\
\text { mais longe... [e fez a outra } \\
\text { máquina] } \\
\text { [Acabou?] Não, falta } \\
\text { desenhar o J. [irmão], falta } \\
\text { desenhar o J. [irmão]. }\end{array}$ & $\begin{array}{l}\text { O menino é filho de uma funcionária } \\
\text { e frequenta muito o Museu. A obra } \\
\text { comentada é do artista francês } \\
\text { Tinguely e não fez parte das } \\
\text { atividades do programa Interar-te. A } \\
\text { criança destacou a interatividade } \\
\text { (acionamento da máquina) e seu } \\
\text { caráter lúdico (movimento). Ou seja, } \\
\text { apontou como importante o contato } \\
\text { com a obra, assim como a companhia } \\
\text { do irmão (paterno) que não mora com } \\
\text { ele e esteve presente em duas sessões } \\
\text { do Interar-te em sua companhia. O } \\
\text { menino (de } 5 \text { anos), já participou de } \\
\text { mais sessões. }\end{array}$ \\
\hline Família 4 & $\begin{array}{l}\text { Masculino, } \\
8 \text { anos }\end{array}$ & 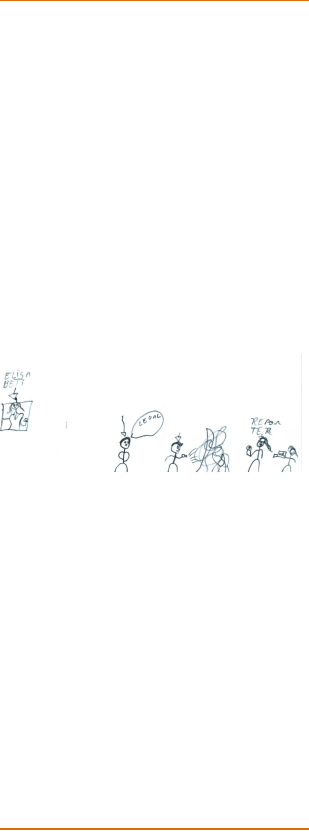 & $\begin{array}{l}\text { Tinha várias gentes vendo a } \\
\text { obra. Tinha pessoa tirando } \\
\text { foto. Tem uma repórter, um } \\
\text { cara filmando. [você os viu } \\
\text { no museu?] Não. [Então } \\
\text { porque você os desenhou?] } \\
\text { Não sei. [E quem é a pessoa } \\
\text { no quadro?] A Elizabeth. É } \\
\text { uma mulher que fica no } \\
\text { quadro. [E o que você mais } \\
\text { gosta quando vai ao museu, } \\
\text { naquela atividade do } \\
\text { Interar-te?] O mais legal é } \\
\text { ver as obras de arte. [E de } \\
\text { qual você mais gostou?] Eu } \\
\text { gostei das do espelho. [obra } \\
\text { de Waldo Bravo na } \\
\text { exposição Cidades } \\
\text { Imaginaddas, onde imagens } \\
\text { distorcidas eram vistas } \\
\text { normalmente apenas por } \\
\text { um espelho ao alto ou } \\
\text { abaixo da imagem.] }\end{array}$ & $\begin{array}{l}\text { Este menino mora em uma cidade do } \\
\text { interior, onde não há museu de arte. } \\
\text { Participa do programa Interar-te ao } \\
\text { passar as férias com o pai, que mora em } \\
\text { São Paulo. Ele destacou as obras de arte } \\
\text { como parte mais importante para ele do } \\
\text { programa Interar-te. O desenho possui } \\
\text { partes imaginárias, como uma repórter, } \\
\text { um cinegrafista e um fotógrafo } \\
\text { registrando as obras, uma pintura e uma } \\
\text { escultura, além dele e do irmão (que não } \\
\text { mora com ele; ele possui um outro } \\
\text { irmão por parte de mãe, com } 2 \text { anos, } \\
\text { que mora com ele). Checando a relação } \\
\text { com os fatos presenciados no Interar-te, } \\
\text { perguntei qual a obra que havia mais } \\
\text { gostado, e a resposta foi sobre obras } \\
\text { discutidas no programa, da qual ele } \\
\text { havia participado. Sem dúvida as } \\
\text { imagens apresentadas os faz relembrar } \\
\text { da participação, muitas vezes até } 4 \text { anos } \\
\text { antes. }\end{array}$ \\
\hline Família 12 & $\begin{array}{l}\text { Feminino, } \\
7 \text { anos }\end{array}$ & 国 & $\begin{array}{l}\text { Aquele negócio que fica } \\
\text { girando... }\end{array}$ & $\begin{array}{l}\text { A garota havia retornado ao Interar-te } \\
\text { na semana da entrevista e associou as } \\
\text { atividades de cinema de animação na } \\
\text { oficina sobre imagem em movimento. } \\
\text { Não fez referência às sessões em que } \\
\text { esteve presente no período pesquisado. }\end{array}$ \\
\hline Família 1 & $\begin{array}{l}\text { Feminino, } \\
11 \text { anos }\end{array}$ & 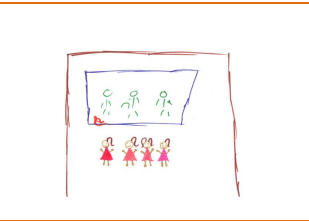 & $\begin{array}{l}\text { Eu fiz uma obra, a gente } \\
\text { olhando. Eram quatro: } \\
\text { eu, a Í., a I. e a J. }\end{array}$ & $\begin{array}{l}\text { Destaca as relações sociais como } \\
\text { fator significativo. Ela e as amigas } \\
\text { citadas iam às sessões do programa } \\
\text { educativo acompanhadas por uma } \\
\text { amiga da família dela (vizinha da avó } \\
\text { da garota num edifício). }\end{array}$ \\
\hline
\end{tabular}




\section{Apêndice 2 - Questionário fechado sobre índice de classificação econômica dos agrupamentos familiares}

\section{Questionário de Classificação Econômica}

Caro participante da pesquisa, estamos the enviando esse questionário como continuidade ao levantamento de dados já iniciado durante a entrevista que o $\mathrm{sr} / \mathrm{a} \mathrm{sr}^{\mathrm{a}}$ nos concedeu. Caso queira consultar os parâmetros de análise, estamos utilizando como base o Critério de Classificação Econômica Brasil da Associação Brasileira de Empresas de Pesquisa, que consta do site: www.abep.org. Com a certeza de contar com a sua colaboração, antecipamos nossos agradecimentos.

1. Sua idade:

(_) 20-25 anos (_) 26-35 anos (_) 36-45 anos (_) 46-55 anos (_) 56 anos ou +

2. Posse de Itens (assinale o número correspondente aos de sua residência):

\begin{tabular}{|l|l|l|l|l|l|}
\hline \multirow{2}{*}{ Item } & \multicolumn{5}{|c|}{ Quantidade de itens } \\
\hline & $\mathbf{0}$ & $\mathbf{1}$ & $\mathbf{2}$ & $\mathbf{3}$ & $\mathbf{4}$ ou + \\
\hline Televisão a cores & & & & & \\
\hline Rádio & & & & & \\
\hline Banheiro & & & & & \\
\hline Automóvel & & & & & \\
\hline Empregada mensalista & & & & & \\
\hline Máquina de lavar & & & & \\
\hline Videocassete e/ou DVD & & & & & \\
\hline Geladeira & & & & & \\
\hline Freezer (aparelho independente ou parte da geladeira duplex) & & & \\
\hline
\end{tabular}

\section{Grau de Instrução do chefe de família}

a. Quem é chefe de sua família?

(_) você (_) cônjuge (_) outros:

b. Grau de instrução do chefe de família (assinale a opção correspondente):

\begin{tabular}{|l|l|l|}
\hline Nomenclatura antiga & Nomenclatura atual & Sim \\
\hline Analfabeto/Primário incompleto & $\begin{array}{l}\text { Analfabeto/Até } 3^{\mathrm{a}} \text { série do Fundamental / } \\
\text { Até } 3^{\mathrm{a}} \text { série do } 1^{\circ} \mathrm{Grau}\end{array}$ & \\
\hline $\begin{array}{l}\text { Primário completo / Ginasial } \\
\text { incompleto }\end{array}$ & $\begin{array}{l}\text { Até } 4^{\mathrm{a}} \text { série do Fundamental } / \text { Até } 4^{\mathrm{a}} \text { série } \\
\mathrm{do} 1^{\circ} \text { grau }\end{array}$ & \\
\hline $\begin{array}{l}\text { Ginasial completo / Colegial } \\
\text { incompleto }\end{array}$ & Fundamental completo $/ 1^{\circ}$ Grau completo & \\
\hline $\begin{array}{l}\text { Colegial completo / Superior } \\
\text { incompleto }\end{array}$ & Médio completo $/ 2^{\circ}$ Grau completo & \\
\hline Superior completo & Superior completo & \\
\hline
\end{tabular}

Critério de Classificação Econômica Brasil, da Associação Brasileira das Empresas de Pesquisa (ABEP) - disponível em www.abep.org. 
Apêndice 3 - Dados da equipe de educadores assistentes (bolsistas e estagiários) do programa Interar-te do MAC USP

\section{1 - Relação de atividades do período em estudo nos quais atuaram}

\begin{tabular}{|c|c|c|c|c|}
\hline № & Oficina & Exposição & $\begin{array}{c}\text { Mês da } \\
\text { oficina }\end{array}$ & \begin{tabular}{|c|} 
PARTICIPEI \\
(assinale com um x)
\end{tabular} \\
\hline 1 & Bonadei: Criando Moda & $\begin{array}{l}\text { Bonadei: Percursos } \\
\text { Estéticos }\end{array}$ & out/06-jan/07 & \\
\hline 2 & Ateliê: Abstraindo... & $\begin{array}{l}\text { Bonadei: Percursos } \\
\text { Estéticos }\end{array}$ & out/06-jan/07 & \\
\hline 3 & $\begin{array}{l}\text { O Mundo e a Arte - } \\
\text { questões de nosso século } \\
\text { nas obras de Rauschenberg }\end{array}$ & $\begin{array}{l}\text { Arte Contemporânea - } \\
\text { Aquisições Recentes } \\
(1990-2005)\end{array}$ & março 07 & \\
\hline 4 & Chegar lá... Onde mesmo? & $\begin{array}{l}\text { Mulheres Artistas: Olhares } \\
\text { Contemporâneos }\end{array}$ & abril 07 & \\
\hline 5 & $\begin{array}{l}\text { Especial com a artista Beth } \\
\text { Moysés }\end{array}$ & $\begin{array}{l}\text { Mulheres Artistas: Olhares } \\
\text { Contemporâneos }\end{array}$ & maio 07 & \\
\hline 6 & Vendo Palavras & $\begin{array}{l}\text { Mulheres Artistas: Olhares } \\
\text { Contemporâneos }\end{array}$ & junho 07 & \\
\hline 7 & $\begin{array}{l}\text { Memórias do dia-a-dia em } \\
\text { transformação }\end{array}$ & $\begin{array}{l}\text { Arte Contemporânea - } \\
\text { Aquisições Recentes }\end{array}$ & julho 07 & \\
\hline 8 & $\begin{array}{l}\text { Quantas cidades nessa } \\
\text { mesma São Paulo! }\end{array}$ & $\begin{array}{l}\text { Radiografias da Cidade: } \\
\text { Gregório Gruber e Bruno } \\
\text { Giovannetti }\end{array}$ & agosto 07 & \\
\hline 9 & Qual é nosso horizonte? & $\begin{array}{l}\text { Radiografias da Cidade: } \\
\text { Gregório Gruber e Bruno } \\
\text { Giovannetti }\end{array}$ & setembro 07 & \\
\hline 10 & $\begin{array}{l}\text { Especial com o artista } \\
\text { Carlos Delfino }\end{array}$ & Dia da Criança Especial & outubro 07 & \\
\hline 11 & Coisas de Família & $\begin{array}{l}\text { Mirada - Latino- } \\
\text { americanos do MAC USP } \\
\text { no Memorial }\end{array}$ & novembro 07 & \\
\hline 12 & Marcas de Gerações & $\begin{array}{l}\text { Street Art - do grafites à } \\
\text { pintura }\end{array}$ & janeiro 08 & \\
\hline 13 & TransformAÇÃO & $\begin{array}{l}\text { Street Art - do grafitos à } \\
\text { pintura }\end{array}$ & fevereiro 08 & \\
\hline 14 & $\begin{array}{l}\text { Especial com a artista } \\
\text { Paola Parcerisa }\end{array}$ & $\begin{array}{l}\text { Mulheres Artistas: Relatos } \\
\text { Culturais }\end{array}$ & março 08 & \\
\hline 15 & $\begin{array}{l}\text { Dia após dia, a gente vai } \\
\text { levando. Até quando? }\end{array}$ & $\begin{array}{l}\text { Mulheres Artistas: Relatos } \\
\text { Culturais }\end{array}$ & abril 08 & \\
\hline 16 & Macias Lembranças & Poéticas da Natureza & maio 08 & \\
\hline 17 & $\begin{array}{l}\text { Especial com o artista } \\
\text { Christophe Spoto }\end{array}$ & Poéticas da Natureza & junho 08 & \\
\hline 18 & $\begin{array}{l}\text { Especial com a artista } \\
\text { Regina Carmona }\end{array}$ & Poéticas da Natureza & julho 08 & \\
\hline 19 & $\begin{array}{l}\text { Especial com a artista } \\
\text { Renata Barros }\end{array}$ & Poéticas da Natureza & agosto 08 & \\
\hline
\end{tabular}




\begin{tabular}{|c|c|c|c|}
\hline 20 & $\begin{array}{l}\text { Vendo o Mundo de Ponta- } \\
\text { cabeça }\end{array}$ & $\begin{array}{l}\text { Fotógrafos da Vida } \\
\text { Moderna }\end{array}$ & setembro 08 \\
\hline 21 & $\begin{array}{l}\text { Quem é você (hoje)? } \\
\text { Dia da Criança }\end{array}$ & $\begin{array}{l}\text { MAC Contemporâneo - } \\
\text { Instalações }\end{array}$ & outubro 08 \\
\hline 22 & $\begin{array}{l}\text { O que seria de nós se eles } \\
\text { não tivessem existido? }\end{array}$ & $\begin{array}{l}\text { MAC Contemporâneo - } \\
\text { Instalações }\end{array}$ & novembro 08 \\
\hline 23 & $\begin{array}{l}\text { Um dia igual porém } \\
\text { diferente }\end{array}$ & Superfícies da Memória & janeiro 09 \\
\hline 24 & $\begin{array}{l}\text { Qual seu pé de árvore mais } \\
\text { querido? }\end{array}$ & Superfícies da Memória & fevereiro 09 \\
\hline 25 & Impressões do Parque & Arte Frágil - Resistências & maio 09 \\
\hline 26 & Denúncia e resistência & Arte Frágil - Resistências & julho 09 \\
\hline 27 & $\begin{array}{l}\text { Arman - Impressões de } \\
\text { resíduos }\end{array}$ & $\begin{array}{l}\text { Uma Aventura Moderna - } \\
\text { Coleção de Arte Renault }\end{array}$ & setembro 09 \\
\hline 28 & $\begin{array}{l}\text { Rauschenberg - } \\
\text { Impressões de olhares }\end{array}$ & $\begin{array}{l}\text { Uma Aventura Moderna - } \\
\text { Coleção de Arte Renault }\end{array}$ & outubro 09 \\
\hline 29 & $\begin{array}{l}\text { Doisneau - Impressões do } \\
\text { trabalho }\end{array}$ & $\begin{array}{l}\text { Uma Aventura Moderna - } \\
\text { Coleção de Arte Renault }\end{array}$ & novembro 09 \\
\hline 30 & São Paulo - Cidade plural & Cidades Imaginadas & janeiro 10 \\
\hline 31 & Memórias de Carnavais & $\begin{array}{l}\text { Coleções sob a guarda } \\
\text { provisória do MAC-USP }\end{array}$ & fevereiro 10 \\
\hline 32 & $\begin{array}{l}\text { Eu quero um bichinho de } \\
\text { estimação! }\end{array}$ & $\begin{array}{l}\text { Coleções sob a guarda } \\
\text { provisória do MAC-USP }\end{array}$ & março 2010 \\
\hline 33 & $\begin{array}{l}\text { Da cidade em que vivemos } \\
\text { à cidade que queremos }\end{array}$ & $\begin{array}{l}\text { Cidades Imaginadas e } \\
\text { Cidades Imaginadas Ibero- } \\
\text { americanas }\end{array}$ & abril 2010 \\
\hline
\end{tabular}




\section{2 - Questionário aberto aos educadores assistentes (antes da entrevista por grupo focal)}

\section{Dados}

Nome:

Idade :

Período do estágio ou bolsa no MAC-USP:

Formação acadêmica (curso, instituição, ano de formação):

Atuação profissional atual (caso graduado):

\section{Questões}

Qual o impacto do estágio em sua formação acadêmica, profissional e pessoal?

Observe as imagens das atividades das quais participou. Qual melhor representa o Interar-te, para você?

Exposição/atividade:

Descrição/justificativa: 


\title{
3.3 - Planejamento da entrevista por grupo focal
}

\author{
Entrevista por grupo focal \\ Assistentes (bolsistas e estagiários) MAC USP
}

Procedimentos dirigidos à pesquisadora:

- Instruir a falarem um por vez, anotando questões para intervenção controlada, para clareza no registro em áudio;

- Entregar o auxílio transporte.

Entrega de formulários aos entrevistados. Solicitar:

- leitura e assinatura, em caso de concordância, do termo de consentimento livre e esclarecido;

- que assinalem, na tabela entregue, as atividades das quais participaram;

- que respondam o questionário.

Questão motivadora da entrevista por grupo focal:

- O que foi mais marcante, para você, no Interar-te? (pesquisadora: focar nos aspectos que puderam observar acerca das relações familiares entre os participantes, assim como nas demais questões pertinentes que forem apontadas pelo grupo). 


\section{4 - Transcrição da entrevista por grupo focal}

\section{Equipe MAC USP - Bolsistas e Estagiários (janeiro/2011)}

Compareceram: D., K., L., P., R. O. e R. S. .

Pesquisadora - A questão motivadora do debate é "O que foi mais marcante para você no Interar-te?"

K. - Bem, para mim primeiro foi o contato com arte contemporânea, porque até o momento em que comecei a fazer estágio lá, a academia falava muito pouco de arte contemporânea, ou nem falava de arte contemporânea. Então, foi o primeiro lugar que eu tive contato com arte contemporânea e comecei a pensar sobre o assunto - porque, a partir do momento que você vai ser um mediador, tem que discutir e já vai buscar referências. Então é mais do que aprender sobre a questão educativa; para mim, foi aprender sobre arte contemporânea... tinha uma questão das relações, tinha a questão familiar, mas, acima de tudo, tinha um processo pra chegar até ali. E isso me marcou muito em muitos aspectos, em ter vontade de começar eu mesma a produzir, vontade de trabalhar com arte-educação... Até então eu não sabia o que era ser um arte-educador, foi meio que junto com as disciplinas, as aulas foram aperfeiçoando isso. E acho que uma outra coisa que me marcou é aquela leitura despretensiosa, não era leitura de estudante de arte, não era leitura de adulto que acha que sabe. Eram crianças e pais que estavam sempre naquela rotina do dia a dia, do cotidiano... então o Interar-te parecia que os trazia pra uma outra realidade que eles não estavam acostumados: quantos pais pintados como os filhos; sujos, iguais aos filhos! Então essa relação colaborativa dos dois era muito marcante, porque a criança tem aquela coisa espontânea, fala coisas legais, foi lá também que eu me "liguei"; e foi muito prazeroso.

L. - Eu acho que o meu depoimento vai ser bem mais egoístico do que o da K., eu acho importante esse contato, de assistir e de participar dessa relação de familiar que pode ser contrastante mas é super rico quando você coloca uma criança junto de um adulto no ateliê, com uma proposta junto, em que as diferenças e as permissões que cada uma das idades traz. E fazem com que a coisa seja construtiva, assim, juntos. Mas eu acho que o Interar-te foi o primeiro trabalho que eu tive, com educativo, que me permitiu assim, ter uma participação crítica. Porque às vezes eu acho que o trabalho educativo dentro do museu pode se perder um pouco, como... como perfumaria ou suporte, ou algum supositório, pra cumprir uma tarefa burocrática, um protocolo do museu. Eu acho que essas atividades dialogavam com as 
atividades do museu, com as exposições e os conteúdos das exposições, mas elas também eram independentes, porque o trabalho educativo dentro do museu não tem que ser só esse suporte, mas ele é uma outra coisa; na verdade, ele trata de educação, mas também de acessibilidade, né. Mas eu acho que o que ele me trouxe de mais interessante foi pensar, foi poder pensar, me aproximar das exposições de arte contemporânea, enfim, como a K. falou, mas poder participar pensando as oficinas, pensando as atividades, e tendo essa interação com os grupos no atelier. Pra mim foi mais rico assim. A maior parte das outras experiências educativas que eu tive me tratavam como educador, me colocavam na posição de educador que era subordinado ao conteúdo, ao que era trazido pelo trabalho do artista, pelo curador, e me fazia com que eu estendesse essa subordinação à participação do público - que também vinha como subordinado. E o trabalho de ateliê coligado com a discussão da exposição e com a visita à exposição, essa conversa que ela consegue com o público, fazia com que ela fosse para outros lugares: com que o público fosse participante também, as crianças, as famílias... [ele trata da mediação numa perspectiva vygotskyana]. Então, pensar as oficinas, pensar os objetos, pensar as atividades de ateliê... testar antes, ter um tempo de, enfim, brincar com os materiais, fazer entre a gente, eu, a Andrea, o D. [bolsista de outros programas educativos que participava do preparo das atividades e discussões, mas não assistia às oficinas aos finais de semana] sei lá, a T. esteve com a gente por um tempo, também... pra mim, era a parte mais rica. E ver acontecer também era muito bacana, era muito gratificante. Também me fez pensar a prática criativa, quando a gente está no ateliê criando, como experiência que não precisa ser individual [interessante colocação na atualidade da produção artística, dado o número de chamados coletivos] e pensar, porque eu também sou... eu também sou artista e aí... pra mim, a coisa do atelier era um pouco... me fechar num lugar e fazer... e acho que foi a primeira experiência. Apesar de estudar numa sala de aula com quarenta pessoas na época da faculdade, eu me fechava no ateliê e fazia o meu e não queria contato. E quando você é o propositor de uma oficina, de um ateliê, você também quer ver um resultado plástico, mas o resultado não é a coisa, mas a interação, a forma como isso se constrói. O que as pessoas vão agregar participando da proposta, fazendo, enfim, faz com a coisa toda do ateliê seja muito mais interessante, muito mais rica. E acho que isso também transformou o que eu achava que era o trabalho de um artista, o que eu achava que seria do meu trabalho como artista. Assim, eu acho que a parte de ateliê foi a mais rica, para mim. [Se estudantes de artes visuais obtiveram esta percepção, embora destacando o processo de elaboração das atividades, da exposição ao ateliê, digo que os participantes podem ter uma experiência educativa com procedimentos, questões e fazeres da linguagem das artes visuais, com o objetivo do 
programa, que é fazê-los aprender arte também pelo contato com procedimentos próximos aos dos artistas, no intuito de facilitar a compreensão da artes]. Eu me encontrei, na verdade. Trabalhei em vários outros lugares depois, e acho que é uma tarefa fundamental, num museu, pensar o público como participante e pensar o departamento educativo. Vamos colocar como uma área independente e importante dentro do museu e, não, uma área subsidiária.

R. S. - Eu tomei contato com o programa numa fase que ele estava mais consolidado já, né, meu próprio viés de olhar é diferente, porque eu não sou das artes, eu sou da História. E pra mim, o que sempre me pega é essa preocupação - e eu vejo isso pouco no museu assim, no MAC, né? - que é bem no sentido do que o L. tava falando, que é essa preocupação com a formação do público. A gente teve algumas experiências que mostram, principalmente no Recreio nas Férias, que o museu pode ser um lugar que é bem opressor até, que as pessoas não conseguem se sentir parte do lugar, né? E eu acho que a forma do programa, essa questão combinada entre a discussão da apreciação estética e a oficina no ateliê colabora pra romper um pouco isso, e é um pouco o museu exercendo sua função pública, né? Isso é uma coisa que pra mim chama bastante a atenção. Porque (acho que todo mundo aqui sabe) são poucos os bons professores de arte. E (eu) mesmo não frequentava instituição cultural, nunca tive essa coisa de ter um ateliê direcionado, uma proposta com objetivo... eu nunca tive em toda minha formação, tanto no primário quanto no ginásio e no colegial. Sempre tive aqueles professores de: “ah, vamos fazer! Pode fazer o que quiser!"... e eu nunca me senti instigado, e eu acho que é a grande questão do ateliê, tal qual ele funciona no programa, é isso: a gente prepara uma proposta e a gente instiga as pessoas, e eu acho que é justamente esse movimento de instigar que faz elas se sentirem parte e tudo o mais. Não é uma proposta demasiado fechada, mas também não é aquela coisa do tipo fazer por fazer.

D. - Bom, eu tenho muito da questão do L. também. Eu tinha muito trauma em relação à educação. Na faculdade, eu não ia seguir por esse caminho. Era uma opção já definida quando eu prestei artes visuais, que tinha já essa nova possibilidade de licenciatura. Mas, a partir do momento que surgiu essa oportunidade do estágio, eu tive contato com o pensamento da Andrea e isso me fez mudar de caminho mesmo. É, essa parte de ter participado do ateliê, de ter participado do Interar-te, de outras atividades e grupos, propostos pela Andrea, me fez ter uma visão muito diferente e muito construtiva acerca da educação mesmo. Na verdade, pensando assim, eu não tive vontade de seguir em outros caminhos de educação mas, como artista, isso me completou. Isso que a K. comentou, de que foram as aulas mais importantes de arte contemporânea, de que isso me trouxe uma consciência artística muito importante mesmo, de estar do outro lado, pensar como o espectador, como uma pessoa comum vai ter o 
contato com a obra, com a arte, através de um mediador... isso me fez ter uma reflexão diferente como artista. Eu acho que esse foi o ponto principal da minha formação. Depois eu também passei por outros trabalhos também ligados à educação, e não tive a mesma vontade de continuar, porque era outra forma, outro pensamento, outra maneira de lidar com isso, e hoje eu estou tendo a oportunidade de idealizar um espaço que tem arte, e a minha vontade é ter um educativo pensado nesses programas que eu vivi dentro do MAC, com a Andrea, pensando nessa fase que, pra mim, foi muito, muito importante, grandioso e... acho que é isso. R. O. - Bom... a minha formação não é artes plásticas, eu venho da letras e, assim como a D., eu não tinha vontade de seguir na área de educação, eu tinha pensado em fazer o bacharel(ado), trabalhar com outras coisas que não estavam ligadas necessariamente à educação e, quando eu entrei no MAC, algo foi ativado pelas oficinas que eu vi e pela vivência com a arte-educação. Por incrível que pareça, eu nunca tinha entrado num educativo, eu não conhecia o trabalho de um setor educativo e tinha até preconceito, na verdade. $\mathrm{E}$, depois que eu comecei a trabalhar no MAC, e a vivenciar as oficinas - tanto do Interar-te como dos outros programas - eu comecei a ver como o trabalho do setor educativo é importante pra gente, não só para compreender o conteúdo da exposição, mas... Foi muito bom pra perceber que, sei lá, eu posso levar em consideração vários outros olhares e perspectivas, da arte mesmo, e o interessante, uma coisa que fica marcada pra mim, é a multiplicidade de pessoas vindas de várias classes sociais participando do Interar-te; isso pra mim foi bastante significativo. Eu já participei de oficinas de arte (ressalta a leitura e o debate, não o discurso fechado sobre a obra. Ela levou a família numa sessão - mãe e primos jovens) não dos educativos de outras instituições, mas um curso de arte dentro da USP mesmo - e, até então, eu nunca tinha visto essa mistura de públicos. Por exemplo, no último Interar-te que foi feito, em janeiro de 2011, estavam participando da oficina: um funcionário da USP, com o filhinho, e pessoas que provavelmente eram moradoras ali da região, do, sei lá, dos Jardins, que circunda o parque do Ibirapuera! E não foi a primeira vez que eu presenciei isso (ressalto que essa sessão não integra o período selecionado para a amostra de entrevistados) e eu acho isso muito bacana. E eu mesma já tive oportunidade de levar meus familiares para participar de oficinas no MAC e isso os aproximou bastante da arte. Assim, por exemplo, eu levei o meu primo, um primo meu que nunca tinha entrado num museu e... ele curtiu pra caramba a oficina, e passou a visitar museus depois desse contato - e depois de fazer a oficina do Interarte (formando hábito de frequentação).

P. - Bom, assim como a R.O., eu não sou das artes plásticas, mas extraoficialmente eu já tive contato com esse universo por conta do meu pai, que foi um artista plástico frustrado, teve 
que abandonar a profissão por outro sonhos também, por algo mais concreto, uma profissão que desse uma certa estabilidade financeira que as artes plásticas não lhe davam. Então, ele acabou se enveredando por outros caminhos, mas a presença de um ateliê sempre foi muito forte na minha casa e, assim como o L. observou, o ateliê, pra mim, era o lugar do meu pai, não era um lugar em que eu e meus irmãos - a minha família é bastante numerosa - não era um lugar que nós poderíamos frequentar a todo e qualquer momento. Era um lugar reservado, que ficava ali, ele com a arte dele, tendo inspirações e tendo, ali, certas ideias que ele ia colocando no papel e depois ia realizando. E era um trabalho comercial, então, nós não interferíamos porque sabíamos que uma interferência poderia desvalorizar o trabalho dele e comprometeria até o nosso orçamento. E, quando eu fui pra universidade, eu já pensava em trabalhar com educação, porque eu já tinha feito magistério e eu gostava muito de artes plásticas. Eu tive bons professores, eu acho que isso foi fundamental pra minha vida, pra constituição do meu eu; assim, embora eu talvez não venha a trabalhar com arte-educação... futuramente tudo pode ser... mas eu sabia que eu gostaria de enveredar pelos caminhos da educação, e eu observava que o desenho tinha um papel fundamental na vida das crianças, inclusive a psicologia tem um estudo que desvenda certos traços de personalidade, ou até mesmo questão da agressão, desvendando os desenhos das crianças. Isso me motivava muito, até pensei fazer psicologia, talvez com foco nessa área, numa espécie de ludoterapia, porque a forma da criança brincar também representa um desenho no espaço físico. E, quando eu vi essa oportunidade de trabalhar no MAC, eu fui consultar aquela planilha qual seria o tipo de trabalho que eu deveria realizar, e o que me chamou muito a atenção foi que o estagiário participaria de todo o processo. Eu não executaria só a monitoria, mas eu participaria de todo o processo, e isso foi muito importante, muito marcante no Interar-te, porque eu via ali a atividade sendo realizada, mas eu tinha participado do processo da elaboração, eu tinha pensado junto com a Andréa e com as outras estagiárias (com a K., muitas vezes, com a D....), e nós pensávamos juntas: o que é que rola, o que é que não rola, o que é que é demais, talvez, pra um público... não que nós estivéssemos subestimando o público que frequentava o MAC, mas arte contemporânea, pra mim, era um mistério também... eu gostava muito de arte, mas estava muito focada numa arte mais clássica, uma arte que representava quase que fielmente as paisagens, era praticamente a fotografia da época. Então a minha ideia de arte era muito diferente de quando eu entrei no museu. E, ali, eu pude perceber que a arte contemporânea não era um bicho de sete cabeças, que ela estava muito mais ligada aos porquês, às questões mais pessoais do artista, do que fazer um trabalho bonito que agradasse ao público. E eu percebi que o público também tinha as mesmas dificuldades que eu tive, no momento de 
adentrar o museu de arte contemporânea porque, por incrível que pareça, a primeira vez que eu pisei no MAC foi quando eu fui fazer a entrevista com a Andrea. Eu nunca tinha ido nem no MAC sede, que ficava lá no campus, passava na frente, achava bonito aquela entrada suntuosa, aquelas obras já ali na frente dialogando com o espaço do campus, mas muitas das obras eu achava "nossa, que piração, que artista maluco!" E foi a primeira vez que eu entrei no MAC, justamente para fazer a entrevista pra trabalhar no projeto, e nós vimos um trabalho da Nina Moraes e a Andrea pediu pra nós falarmos a respeito da obra, e foi uma loucura, falei: “meu Deus, eu vou começar a viajar aqui, quem sabe dá certo!" (risos) E isso acontecia depois, no ateliê, no Interar-te, a gente deixava os adultos falarem, as crianças também falavam - como a K. bem observou - e essa leitura, assim, sem compromisso, "é o que eu acho e pronto, acabou!", isso era muito bacana, porque nós já tínhamos feito todas as pesquisas, já tínhamos lido o que o artista talvez ... qual era a proposta, qual era a poética do artista... mas ali, no Interar-te, não, "eu acho, pronto, e acabou, é isso. E eu vou fazer isso: segundo a proposta que vocês me deram, eu também vou inventar; eu não tô nem aí!” Algumas crianças até relatavam: "ah, eu também vou ser artista, porque aqui eu sou artista!" E isso foi muito legal, porque eu fiquei muito balançada, eu quase mudei de área, comecei a ver de novo o processo seletivo da FUVEST, como seria mudar de área... mas a questão burocrática acabou impedindo que eu fizesse esse caminho, esse retorno, porque eu estava disposta a prestar vestibular de novo, e entrar e fazer artes plásticas, mas eu acabei, por questões da vida, achando que não era o momento, que o momento mesmo já tinha passado, que se essa escolha tivesse que ter sido feita, deveria ter sido feita no momento que eu prestei a FUVEST e fui aprovada no curso de letras. Eu julguei que fosse tarde, mas é algo que me encantou, sempre me encantou muito e eu sou muito apaixonada por essa área. Depois eu fui trabalhar num outro centro cultural ligado à universidade, que é a Casa de Dona Yayá, e tudo o que eu vivenciei no MAC foi muito importante pra que eu estivesse ali, naquele espaço expositivo. Também tinha umas exposições itinerantes... o objeto era a casa em si, mas tinha outras exposições interessantes, e foi um aprendizado pra vida e... foi muito bom.

R. O. - E... o que me fez também querer fazer parte, me fez querer participar, me inscrever lá no programa Aprender com Cultura e Extensão e trabalhar no MAC, foi a questão de eu perceber, no MAC, a vivenciar diariamente a possibilidade de trabalhar com educação e ver que é possível trabalhar a interdisciplinaridade - o que nas outras áreas não se encontra. Por exemplo: eu vou dar aula de português e vou ficar lendo português. Sei lá, é difícil abarcar outras áreas e... essa divisão de saberes sempre me incomodou muito na educação, sempre tive vontade de, sei lá, de trabalhar com essa mistura de saberes de várias áreas e a questão 
que eu percebi em vários Interar-te, que é... percebi que, em vários momento,s em várias oficinas, a atividade rolava tão legal que era como se fosse uma... como se estivesse rolando uma terapia familiar em grupo, sabe, porque hoje em dia é difícil, principalmente nas classes mais altas, os pais se relacionarem com os filhos. É ver de perto algum talento que o filho tenha e, no Interar-te, eu presenciei várias cenas de uma mãe falando: “ai filho, seu trabalho é lindo, eu não sabia que você curtia fazer isso!” A mãe se aproximando mais do filho; eu achei isso super bacana.

K. - Claro que, quando perguntam o que marcou, a gente lembra de algumas coisas e, depois repensa, e aí um outro fala e você fala "eu também acho isso!", e você pensa "não, tem a minha questão, do que me marcou na minha vida, e a questão do que eu acho do programa que eu vejo de relevante dentro desse processo"; e eu acho que todo mundo acabou falando os dois pontos, né?, as questões relevantes e as questões que marcaram algo mais particular. Assim - e pensando agora foi depois de todo mundo falando que eu percebi uma outra coisa, que acho que une também o comentário de várias pessoas - é raro ter um espaço como o MAC tem hoje, que é o Interar-te, porque - assim como as outras pessoas também falaram - quando eu saí do MAC e fui convidada pra ser monitora de um outro espaço cultural, eu vi que não tinha nada lá e que as pessoas nem sabiam o potencial histórico-artístico, enfim, patrimonial, que as instituições de cultura têm. Assim, esse trabalho faz com que a gente tire um pouco dessa coisa meio aurática que as instituições têm. Então, de uma certa forma, não é só a questão da contemporaneidade, que já tem um pouco desse perfil que é tirar essa aura do artista e trazer ele com uma poética material que seja mais acessível, né. Hoje a arte contemporânea não tem mais essa coisa tão aurática como tinha uma arte produzida com materiais mais clássicos, sei lá se eu posso dizer isso, mas não é só a questão do Interar-te num museu de arte contemporânea. Eu acho que a ideia toda do projeto, mesmo se estivesse numa instituição mais patrimonial, eu acho que ela também conseguiria ter um resultado por causa disso, porque a ideia é justamente, como o R.S. falou: formar o público. Então você aproxima, você tira aquela pessoa da sua rotina, então você acaba despertando outras coisas. Então tem essa questão também de ser formação de público - que foi o meu caso, assim, depois que eu fui pra uma instituição que era só patrimonial... eu tentei usar tudo aquilo que eu tinha visto dentro de um museu de arte contemporânea. E algumas coisas deram certo; e aí que eu percebi: “ah, então tá, a ideia via muito mais além de estar num ambiente de arte contemporânea!" E eu achei isso incrível, assim, que talvez todas as instituições devessem, sei lá, ter o educativo conversando mais uns com os outros. Se tem, eu não estou sabendo, mas talvez devesse conversar mais. 
L. -...na verdade eu perdi o fio da meada mas comecei a pensar em outra coisa... Eu acho importante e interessante do projeto o fato de transformar a vivência dentro do museu, a vivência dentro do ateliê em vivência mas, também, em um espaço de convivência, né, pensando como um sufixo de união. E transformar isso em uma prática familiar, um momento familiar. Porque as crianças vão ao museu, às vezes, com a escola e, talvez, depois de uma certa idade, elas possam ter autonomia para irem sozinhas e tal. Mas eu acho interessante que isso vire um tipo de contato entre pai e filho. Assim... a P. comentou da relação dela, por conta do trabalho do pai dela... meu pai trabalhava com arquitetura também, também tinha um olhar meio... acho que eu tenho um olhar mais sensível, pela experiência particular mas, de uma forma ou de outra, por mais que um artista, sei lá, trabalhe com um site specific, tenha um trabalho mais político e tudo o mais, acho que o fato de escolher ser artista e de trabalhar, de se expressar dessa maneira, de expressar o que quer que seja, está ligado, em alguma medida, com a subjetividade. E tem que estar ligado porque, nem sempre, as pessoas que vão olhar vão pensar naquilo como o suporte de um discurso, mas está ligado ao sensível, ao sensível das pessoas também. Então acho que tem esse lado, e acho interessante ligar isso também com a experiência familiar: acho que a coisa do ateliê, de estar ali, e de fazer, e de se sujar, pára um pouco a coisa hierárquica de ser o pai e o filho; ele leva o filho e o filho faz; ele assiste, está ali. Você coloca o filho para colocar uma máscara de gesso no rosto do pai e superar o Édipo dele... asfixiando o pai e, fazendo uma máscara linda depois e... decorada . E eu acho que isso eleva mesmo essa experiência da arte para outros patamares, não só de superação, mas afetivo mesmo, porque eu acho que também cria memórias e cria um outro tipo de vínculo - não necessariamente de afeto, mas de experiência mesmo com a arte, e com o museu.

R.S. - Depois que essa questão mais pessoal foi pautada... por eu não ter a vivência do mundo artístico, muitas vezes, me sugeriam que eu fizesse as oficinas... bem de leve, assim, "faça!". Aí, eu parava o que estava fazendo e participava, ajudava as pessoas e tal, mas isso foi um exercício importante, porque me deu muita dimensão da importância da capacidade do ateliê e aí... tô falando isso porque as pessoas começaram a falar das questões pessoais... e eu, por não ter a vivência no mundo artístico, seja como fruidor, seja como produtor... eu também, a primeira vez que pisei no museu foi para fazer a entrevista com a Silvana e tal. Pra mim, marcou muito a do Arman, assim, na exposição da Renault e tal, que essa questão do trabalho que ele faz com a questão das repetições... e a Andrea teve uma sacada que eu achei genial: o mesmo saco de brinquedos que vocês coletaram e fizeram, juntaram tudo... o Arman faz o trabalho dele subsidiado pela Renault,, então ele usa peças de motor, ferramenta e tal, e aí ela 
propõe que as crianças - as famílias né, na verdade - façam esse exercício com os brinquedos. E aí, o que é que eu achei? Eu fiz também e o que eu achei é que é uma coisa que eu tinha muita dificuldade... essa relação entre forma e conteúdo. Eu já tinha quase um ano de museu; eu entrei em janeiro de 2009 e isso foi, sei lá, outubro, novembro de 2009. O Arman não trabalhou com o que ele trabalhou para... a princípio, acaba sendo um crítica, uma reflexão sobre a modernidade e tudo o mais, ou uma pós-modernidade, seja lá o que for... mas é porque era necessariamente o objeto ao alcance dele. E eu achei muito feliz o exemplo dessa questão de trazer os brinquedos porque eles são o que as crianças têm no dia a dia; então, aquilo que foi o acaso... "ah, porque brinquedo era o que a gente tinha (no ateliê)... foram os brinquedos que vocês tinham coletado"... ali, no caso da oficina, o ateliê funciona muito bem porque as crianças se identificam com aquilo. Daqueles brinquedos todos, se elas não tinham, elas tinham tido contato com um primo, algum vizinho, o irmão, sei lá. Aí você consegue entender essa questão da disponibilidade do objeto, por exemplo, que é a forma né, através do qual o artista realizou o trabalho, o Arman realizou o trabalho dele. Pra mim, isso foi muito importante esse processo todo me fez sentir à vontade pra... você se sente parte (não sei se parte é a palavra, mas...), você ousa, você pisa num espaço, você vai num museu que você nunca foi e você palpita, você se sente à vontade pra arriscar uma interpretação, você não se sente vítima daquilo, você não se sente como um mero receptor,.. Você pode querer discutir uma interpretação e isso acho que é a coisa mais... acho que o número de pessoas que voltam, é um puta indicativo de que isso acontece de fato, de que as pessoas se apropriam das discussões, se apropriam do espaço. E é aquela velha história, né, que é uma coisa que a Andrea uma vez falou pra Silvana e que a Silvana falou muito pra mim e que acho que é a grande virtude do... da Andrea como educadora... e acho que materializa bem no Interar-te que é... a gente nem sempre pode mudar o mundo, né, mas a gente pode, às vezes, fazer o dia de alguém ser diferente. E ser diferente, no caso, é isso, da pessoa se sentir um pouco mais sujeito, porque são espaços públicos, são espaços públicos que às vezes oprimem, né, e são iniciativas como essas que abrem essa barreira, é o fato de você passar três horas... então, você se apropria daquilo, você se sente à vontade, e isso é importante pra caramba, e me fez começar a frequentar as instituições culturais de São Paulo, coisa que eu não fazia.

L. - Obra de arte emancipa! (risos)

Pesquisadora - Se vocês tiverem algo mais pra falar..., senão, se vocês pudessem resumir em uma palavra a experiência no Interar-te, para vocês, sendo estagiários, ex-estagiários, na formação... pensando numa experiência que vocês levaram pra vida, numa experiência de 
vocês com a arte, numa experiência - como o L. falou - da convivência... reforçando aí o "com"... que palavra seria essa?

D. - Uma só? (risos)

Pesquisadora - Pensando numa síntese dessa experiência...

R.S. - Experimentação.

K. - Autoconhecimento.

D. - Humanização.

R.O. -: Resignificação

P. - Democratização.

L. - Responsabilidade.

Pesquisadora - Vocês têm mais alguma questão?

K. - Eu acho que paixão, porque... quando eu fui na sua sala e você estava desesperada com um monte de livros na mão e... falando que você precisava de alguém ali pra te ajudar... para dar seguimento praquele projeto... então, pode parecer a coisa mais besta, mais pieguinha, mais xôxa, mas, assim... eu já vi projetos educativos acabarem porque acabou. Então, eu acho que você tem que querer fazer. Se não quiser fazer, então nem comece...

D. - Acho que estímulo também, acho que estímulo pra mim é muito forte...

Pesquisadora - Muito obrigada! 


\section{Apêndice 4 - Transcrição de entrevista semiestruturada da Prof $\stackrel{\text { a }}{\text {. Dra }}$. Lisbeth Rebollo Gonçalves, diretora do MAC USP na gestão 2006-2010}

Pesquisadora - Professora, dentre as suas várias atuações profissionais, a sra. atua também como curadora de exposições. A seu ver, qual a relação entre curadoria e educação?

Prof $^{\mathbf{a}}$. Lisbeth Rebollo - Eu acredito que toda atividade educacional realizada no museu tem que estar diretamente ligada à curadoria, caso contrário teremos discursos dissonantes. Hoje em dia o trabalho do curador ultrapassa a questão da organização e supervisão de acervo - vai muito mais além. A curadoria assume o sentido de um escrito sobre arte, ou seja, você tem no trabalho de curadoria um trabalho ensaístico, e ao produzir um escrito sobre arte é preciso entender o conteúdo desse escrito. O trabalho do educador só será compatível com o que está sendo mostrado, nesta ou naquela exposição, se estiver em compasso com este escrito, isto é, articulando com a curadoria, senão vai haver confronto de discursos. Se um profissional atua em museu, acredita-se que siga o que o museu projeta e fundamenta como plataforma institucional. É claro que todo espectador que entrar em uma exposição, todo público visitante, todo outro especialista, poderá ter interpretações diversas da que o curador deu à mostra; pode até discordar, mas acho que no caso do trabalho educativo este deve se apoiar no discurso curatorial, e fazer ver aquilo que o curador, este leitor especializado, traz como interpretação. Claro que deve saber que não é a única interpretação possível. O educador deve inclusive apontar isso. Trata-se, na curadoria, de uma leitura formulada, de um espaço que busca desvendar algo que a arte enigmaticamente pode nos comunicar.

P. - A seu ver qual seria a principal função do setor educativo de um museu de arte?

L.R. - Esta função está explicitada no que respondemos antes: o setor educativo dentro de um museu de arte, como acontece na sala de aula, precisa se apoiar em determinados contextos. No caso do museu de arte, são as exposições de arte; o espaço de mediação com o público é a exposição de arte, é a obra de arte em última instância. No museu de arte, um espaço público que reúne uma coleção, nunca se tratará de uma obra isolada, deve-se sempre abordar a obra dentro de um contexto, dentro de uma conjuntura. A exposição é a extroversão das ideias sobre arte e a comunicação de uma coleção de arte com o público. O valor dessa extroversão se dá quando vamos demonstrar algo - se dá na demonstração, porque sempre há o trabalho de curadoria e, portanto, um trabalho de interpretação. Não se trata de algo definitivo nem único. É uma leitura possível, não é verdade? É difícil você pensar um trabalho do educador de arte fora dessa conjuntura. É preciso entender bem o trabalho do curador e entender bem a exposição como estratégia de mediação da arte para poder fazer um trabalho educacional 
coerente com a finalidade do museu. Na sala de aula, ao trabalhar, claro que é possível valerse de ideias da história da arte, referir períodos da história da arte, obras de um artista, etc. Aí, talvez, a gama de critérios de escolha do educador seja mais ampla. No caso do museu, se não for um museu civilizatório, que vai de um período distante no tempo ao contemporâneo, ele tem limites, pois trata de uma época, de um período, de um tipo de arte. E um tipo de produto artístico pode predominar, como a pintura, a escultura, o desenho ou a arte multimídia, a arte contemporânea, a arte conceitual. Haverá elementos dentro dos quais o educador terá que se mover. Não dá para ir para outros campos, à vontade.

P. - Quais as ações de setor educativo que mais lhe chamaram a atenção, observando museus do mundo? Por quê?

L.R. - Eu acho que... A colocação "observando museus do mundo" é muito ampla, mas tomemos o exemplos de museu com forte infraestrutura, com presença importante no cenário mundial: este tipo de museu oferece produtos muito diversificados. Por exemplo: oferece muito mais que uma visita guiada, que informa e orienta a experiência, a vivência estética in loco, no meio do espaço expositivo, pondo à disposição da criança papel para que desenhe, comente, fazendo-a dar respostas às perguntas do orientador; um orientador que conta histórias a respeito da época do artista, da coleção que está ali sendo mostrada. Este tipo de museu pode oferecer ainda uma série de produtos sobre o artista e a arte de um período. Veja o Louvre, veja o Pompidou, especialmente estes dois museus, e também o d'Orsay, mas sobretudo o Louvre e o Pompidou. Eles têm uma diversidade enorme de produtos que são publicações de histórias adaptadas às faixas etárias, jogos, brinquedos, há bonecos e fantasias - no Louvre, você tem fantasias, as roupas que eram usadas pelas princesas, rainhas, pessoas da nobreza que aparecem naqueles quadros de época. Isso faz com que a criança possa teatralizar, vivenciar a época, vivenciar indiretamente o espaço do museu. Há produtos educativos, mesmo para crianças pequenas, como figuras de uma determinada obra em peças que podem ser montadas como quebra-cabeça, e vai sendo construída uma narrativa desde a infância. E há livros especializados para adolescentes. Então, a gama de produtos é imensa, realmente é imensa. E claro que torna mais eficiente a comunicação com as pessoas e a prática educativa. Considere-se, inclusive, que também as famílias visitam os museus em fins de semana. Isto é comum por lá, famílias levando crianças em carrinhos, parando na frente das obras. Então, é um hábito que é adquirido praticamente desde o berço. O museu é uma opção de lazer. Não é só um lugar para ir conhecer, mas aparece como uma opção de lazer para a sociedade, trazendo desde cedo aos indivíduos um potencial de educação diferenciado. 
Desta forma, dizer o que é mais importante: acho que é tudo junto, porque o que acontece é um processo de construção de valores culturais, de consciência cívica, de amor ao patrimônio, de conhecimento de história, de conhecimento das épocas, de conhecimento de si mesmo. A pessoa encontrará muito da sua própria história no espaço do museu.

P. - Em sua gestão como diretora do o MAC USP, entre 2006 e 2010, a sra. incentivou a criação de um programa para famílias. Quais foram seus objetivos com essa medida?

L.R. - Pareceu-me que, na linha do que disse antes, talvez esse tipo de atividade pudesse ser algo fundamental para a formação do futuro cidadão. Em vez de ir ao museu sozinho ou com o grupo de sua escola, ir com a sua família criaria um sentido diferente para esta vivência. Começaríamos a construir uma experiência de sentido como a que se encontra, por exemplo, na França, quando as famílias, levando seus filhos nos carrinhos, ainda sentadinhos nos carrinhos, visitam o museu e compartilham de modo mais afetivo a experiência de aproximação à arte. Começaríamos a colaborar para acontecer a troca de valores sociais fundamentais no momento da socialização primária, que dá as bases para o futuro cidadão. Na educação familiar estão os pilares de socialização que serão complementados depois pela escola. É claro que, paralelamente, da escola mais elementar até a universidade, no convívio dos museus, vai se construindo o gosto pela arte, o hábito de frequentar estas instituições, e acontecerá a sensibilização, fundamental na formação das pessoas.

P. - A sra. considera que os objetivos do programa Interar-te, durante a sua gestão, foram atingidos? Como que a sra. comenta ou justifica sua conclusão?

L.R. - Nas experiências oferecidas, eu acho que sim. O que poderia é ter acontecido uma oferta maior de atividades, em todos os finais de semana. Mas sei que isto não se deu devido à falta de pessoal envolvido. Claro que se fosse possível ofertar atividades em todos os finais de semana, todos os feriados, a longo prazo os resultados seriam mais produtivos do que ofertando apenas uma vez por mês ou a cada quinze dias. Resposta de público foi sem dúvida obtida e acredito que a procura cresceria com mais oferta destas atividades. À instituição cabe ir criando condições para colher sempre mais e melhores resultados. Fizemos o possível.

P. - Obrigada, professora. 
Apêndice 5 - Termo para autorização de pesquisa à Direção do MAC USP

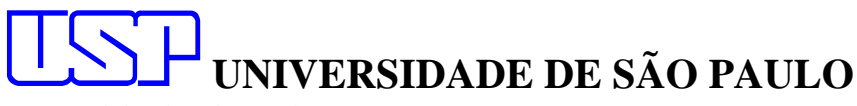

Faculdade de Educação

\section{TERMO DE CONSENTIMENTO LIVRE E ESCLARECIDO Instituição: Museu de Arte Contemporânea da USP}

Sra. Diretora desta instituição,

Estamos desenvolvendo uma pesquisa de título provisório ADULTOS DE AGRUPAMENTOS FAMILIARES QUE FREQUENTAM O PROGRAMA INTERAR-TE DO MAC-USP: MOTIVAÇÕES E ASPIRAÇÕES no âmbito da Pós-graduação, nível Mestrado, na Faculdade de Educação da Universidade de São Paulo e, para isso, gostaríamos de contar com a sua colaboração para autorizar o acesso aos arquivos do programa Interar-te da Divisão Técnico-científica de Educação e Arte do MAC-USP no intuito de levantamento de informações sobre 1 . as estratégias do programa; 2 . contato com a equipe de profissionais e estagiários envolvidos nas atividades; 3. contato com o público frequentador, pelos dados fornecidos para divulgação das atividades, no intuito de convocá-los a participarem do estudo, caso venham a constituir amostra da pesquisa.

Agradecemos sua atenção e colocamo-nos à disposição para dirimir quaisquer dúvidas (Andrea Alexandra do Amaral Silva e Biella - andrea.amaral@usp.br, assim como o contato com a professora orientadora dessa pesquisa: $\operatorname{Prof}^{\mathrm{a}}$. Dr ${ }^{\mathrm{a}}$. Rosa Iavelberg - rosaiave@usp.br).

Nome, cargo e RG

Assinatura

Local e data 


\section{Apêndice 6 - Termo de consentimento livre e esclarecido dos agrupamentos familiares}

\section{TERMO DE CONSENTIMENTO LIVRE E ESCLARECIDO}

Pesquisa: (título provisório) Adultos de grupos familiares que frequentam o programa Interar-te do MAC USP - motivações e aspirações

Instituição: Faculdade de Educação da USP Nível: Mestrado

Pesquisadora: Andrea Alexandra do Amaral Silva e Biella

Orientadora: $\operatorname{Prof}^{\mathrm{a}}$. Dr ${ }^{\mathrm{a}}$. Rosa Iavelberg

Natureza da pesquisa:

Você e as crianças e/ou jovens que lhe acompanharam em sessões do Programa Interar-te do MAC USP serão convidados a participar dessa pesquisa, que tem como finalidade investigar a contribuição dos adultos na formação do hábito de lazer relacionado ao usufruto do patrimônio cultural relacionado às artes, com foco em artes visuais.

\section{Participantes da pesquisa:}

Convite a 18 adultos que frequentaram o programa Interar-te do MAC-USP entre outubro de 2006 e abril de 2010. Participarão os que livremente responderem ao convite para participar das entrevistas.

\section{Sobre as entrevistas:}

As entrevistas serão marcadas com antecedência. Você, as crianças e os jovens terão que responder a algumas perguntas que serão feitas pela pesquisadora, após ela lhes mostrar imagens de vocês em atividade no Programa Interar-te. Além das perguntas, informações básicas serão necessárias, como bairro onde residem, idade e rede escolar dos menores, trabalho formal ou informal dos adultos.

\section{Riscos e desconforto:}

A participação nessa pesquisa não traz complicações, à exceção apenas, talvez, de certa timidez que algumas pessoas têm quando observadas ou gravadas (áudio).

\section{Confidencialidade:}

Todas as informações coletadas nesse estudo são estritamentconfidenciais. A transcrição de áudio das entrevistas, se autorizadas, as atividades realizadas durante as sessões do Interar-te, serão identificados com um código, e não com seu nome ou dos seus acompanhantes menores. Apenas os membros da pesquisa terão conhecimento dos dados. Se você der sua autorização por escrito assinando este termo de consentimento livre e esclarecido, as imagens suas, de seus acompanhantes menores e dos trabalhos realizados no Programa Interar-te (registros digitais) poderão ser utilizados na publicação dessa pesquisa e para fins de ensino durante encontros e debates científicos e acadêmicos.

\section{Benefícios:}

Participando da pesquisa, você e seus acompanhantes menores não terão nenhum benefício direto. Entretanto, esperamos que esse estudo nos dê informações importantes a respeito de motivações e expectativas de adultos que proporcionam atividades de lazer relacionadas à educação a crianças e jovens sob sua tutela. Essas informações poderão ser usadas em benefício de formação cultural e educativa de agrupamentos familiares brasileiros. 


\section{Pagamento:}

Optando por receber a pesquisadora em sua residência ou local de sua preferência (trabalho, entre outros), você não terá nenhum tipo de despesa para participar dessa pesquisa. Também nada será pago por sua participação. No entanto, você receberá cópia dos relatórios da pesquisa contendo resultados do estudo, com foco em sua participação. As imagens digitais de sua participação com os menores acompanhantes lhe serão doadas

\section{Autorizações:}

\section{Uso de imagem}

$\mathrm{Eu}$, , autorizo a mestranda

(FE-USP 2009/2012) Andrea Alexandra do Amaral Silva e Biella a utilizar, para fins da pesquisa (título provisório) “Adultos de grupos familiares que frequentam o programa Interarte do MAC USP - motivações e aspirações", utilizar minha imagem, assim como do(s) menor(es) sob minha responsabilidade nas atividades do Programa Interar-te do MAC-USP, para fins educacionais.

\section{Gravação de voz e publicação de transcrição não identificada} $\mathrm{Eu}$, autorizo a mestranda

(FE-USP 2009/2012) Andrea Alexandra do Amaral Silva e Biella a utilizar, para fins da pesquisa (título provisório) “Adultos de grupos familiares que frequentam o programa Interarte do MAC USP - motivações e aspirações", gravação de voz e publicação de transcrição não identificada, assim como do(s) menor(es) sob minha responsabilidade nas atividades do Programa Interar-te do MAC-USP, para fins educacionais.

Tendo em vista os itens acima apresentados eu, de forma livre e esclarecida, manifesto meu interesse em participar da pesquisa.

Nome completo das crianças ou jovens que me acompanharam nas atividades do Programa Interar-te do MAC USP:

Meu nome completo, como adulto responsável pelos menores acima, número dos documentos abaixo relacionados, assinatura e data:

R.G.:_ órgão expedidor ___ _ _ _

C.P.F.:

Assinatura do adulto responsável

Assinatura da pesquisadora

São Paulo, de de 2010 


\section{Apêndice 7 - Termo de consentimento livre e esclarecido de ex-estagiários ou ex- bolsistas do programa Interar-te do MAC USP}

\section{TERMO DE CONSENTIMENTO LIVRE E ESCLARECIDO de ex-estagiários ou ex-bolsistas do Programa Interar-te do MAC-USP}

Pesquisa: (título provisório) Adultos de grupos familiares que frequentam o programa Interar-te do MAC USP - motivações e aspirações

Instituição: Faculdade de Educação da USP Nível: Mestrado

Pesquisadora: Andrea Alexandra do Amaral Silva e Biella

Orientadora: Prof ${ }^{\mathrm{a}}$. Dr ${ }^{\mathrm{a}}$. Rosa Iavelberg

\section{Natureza da pesquisa:}

A pesquisa tem como finalidade investigar a contribuição dos adultos na formação do hábito de lazer relacionado ao usufruto do patrimônio cultural,com foco em artes visuais.

\section{Participantes da pesquisa:}

Convite a entrevista semi-estruturada aos 18 adultos que frequentaram o programa Interar-te do MAC-USP entre outubro de 2006 e abril de 2010.

Convite a entrevista por grupo focal aos 7 estagiários ou bolsistas que atuaram como assistentes do programa no período citado acima.

Convite a entrevista semi-estruturada à ex-diretora do MAC, diretora no período em estudo.

Participarão os que livremente responderem ao convite para participar das entrevistas.

\section{Sobre as entrevistas:}

As entrevistas serão marcadas com antecedência. Você será convidado a participar de uma conversa com o grupo, a partir de uma questão motivadora que será lançada pela pesquisadora.

Além das perguntas, informações básicas serão necessárias, como formação acadêmica, impacto do estágio em sua vida acadêmica e profissional, idade, atual atuação profissional, caso tenha concluído a graduação.

\section{Riscos e desconforto:}

A participação nessa pesquisa não traz complicações, à exceção apenas, talvez, de certa timidez que algumas pessoas têm quando observadas ou gravadas (áudio).

\section{Confidencialidade:}

Todas as informações coletadas nesse estudo são estritamente confidenciais. A transcrição de áudio das entrevistas, se autorizadas, as atividades realizadas durante as sessões do Interar-te, serão identificados com um código. Apenas os membros da pesquisa terão conhecimento dos dados. Se você der sua autorização por escrito assinando este termo de consentimento livre e esclarecido, as imagens sobre você (registros digitais) poderão ser utilizadas na publicação dessa pesquisa e para fins de ensino durante encontros e debates científicos e acadêmicos. 


\section{Benefícios:}

Participando da pesquisa, você não terá nenhum benefício direto. Entretanto, esperamos que esse estudo nos dê informações importantes a respeito de motivações e expectativas de adultos que proporcionam atividades de lazer relacionadas à educação a crianças e jovens sob sua tutela. Essas informações poderão ser usadas em benefício de formação cultural e educativa de agrupamentos familiares brasileiros.

\section{Pagamento:}

Será oferecido auxílio transporte no valor de sua despesa de deslocamento ao local da entrevista (a partir de 2 conduções, R\$ 6,00); informe o valor à pesquisadora. Por sua participação, nada será pago. No entanto, você receberá cópia dos relatórios da pesquisa contendo resultados do estudo, com foco em sua participação.

\section{Autorizações:}

\section{Uso de imagem}

$\mathrm{Eu}$,

autorizo a

mestranda (FE-USP 2009/2012) Andrea Alexandra do Amaral Silva e Biella a utilizar, para fins da pesquisa (título provisório) "Adultos de grupos familiares que frequentam o programa Interar-te do MAC USP - motivações e aspirações", utilizar minha imagem, nas atividades do Programa Interar-te do MAC-USP, para fins acadêmicos e educativos.

\section{Gravação de voz e publicação de transcrição não identificada}

$\mathrm{Eu}$, autorizo a mestranda (FE-USP 2009/2012) Andrea Alexandra do Amaral Silva e Biella a utilizar, para fins da pesquisa (título provisório) "Adultos de grupos familiares que frequentam o programa Interar-te do MAC USP - motivações e aspirações", gravação de voz e publicação de transcrição não identificada, nas atividades do Programa Interar-te do MAC-USP, para fins acadêmicos e educativos.

Tendo em vista os itens acima apresentados eu, de forma livre e esclarecida, manifesto meu interesse em participar da pesquisa. A assinatura deste termo atesta o recebimento do auxílio transporte.

Meu nome completo, número dos documentos abaixo relacionados, assinatura e data:

R.G.: órgão expedidor (

C.P.F.: 


\section{Apêndice 8 - Termo de consentimento livre e esclarecido da ex-diretora do MAC USP (gestão 2006-2010)}

Pesquisa: (título provisório) Adultos de grupos familiares que frequentam o programa Interar-te do MAC USP - motivações e aspirações

Instituição: Faculdade de Educação da USP Nível: Mestrado

Pesquisadora: Andrea Alexandra do Amaral Silva e Biella

Orientadora: $\operatorname{Prof}^{\mathrm{a}}$. $\mathrm{Dr}^{\mathrm{a}}$. Rosa Iavelberg

\section{Natureza da pesquisa:}

Envolvidos como público e equipe de profissionais relacionados direta ou indiretamente ao Programa Interar-te do MAC USP serão convidados a participar dessa pesquisa, que tem como finalidade investigar a contribuição dos adultos na formação do hábito de lazer relacionado ao usufruto do patrimônio cultural, com foco em artes visuais.

\section{Participantes da pesquisa:}

Convite a: 1.18 adultos e respectivos acompanhantes menores que frequentaram o programa Interar-te do MAC-USP entre outubro de 2006 e abril de 2010; 2.7 educadores assistentes (estagiários e bolsistas) que atuaram no período estudado (10/2006 a 04 de 2010); 3. Diretora do MAC-USP gestão 2006-2010. Participarão os que livremente responderem ao convite para participar das entrevistas.

Sobre as entrevistas:

As entrevistas serão marcadas com antecedência. Você terá que responder a algumas perguntas que serão feitas pela pesquisadora.

\section{Riscos e desconforto:}

A participação nessa pesquisa não traz complicações, à exceção apenas, talvez, de certa timidez que algumas pessoas têm quando observadas ou gravadas (áudio).

\section{Confidencialidade:}

Todas as informações coletadas nesse estudo são estritamente para fins acadêmicos e científicos. A transcrição de áudio da entrevista (se autorizada a gravação) com as informações do depoimento prestado poderá ser utilizada na publicação dessa pesquisa e para fins de ensino durante encontros e debates científicos e acadêmicos.

\section{Benefícios:}

Participando da pesquisa, você não terá nenhum benefício direto. Entretanto, esperamos que esse estudo nos dê informações importantes a respeito de motivações e expectativas de adultos que proporcionam atividades de lazer, relacionadas à educação, para crianças e jovens sob sua tutela. Essas informações poderão ser usadas em benefício de formação cultural e educativa de agrupamentos familiares brasileiros.

\section{Pagamento:}

Optando por receber a pesquisadora em sua residência ou local de sua preferência (trabalho, entre outros), você não terá nenhum tipo de despesa para participar dessa pesquisa. Suas despesas para locomoção até o local da entrevista não serão ressarcidos. Também nada será pago por sua participação. No entanto, você receberá cópia desse termo e dos relatórios da pesquisa contendo resultados do estudo, com foco em sua participação. 


\section{Autorização:}

1. Gravação de voz e publicação de transcrição não identificada

$\mathrm{Eu}$, , autorizo a mestranda da FE-USP (2009/2012)

Andrea Alexandra do Amaral Silva e Biella, para fins educacionais e da pesquisa (título provisório) "Adultos de grupos familiares que frequentam o programa Interar-te do MAC USP - motivações e aspirações", a utilizar gravação de minha voz, assim como da do(s) menor(es) sob minha responsabilidade nas atividades do Programa Interar-te do MAC-USP e a respectiva publicação da transcrição não identificada destas entrevistas.

Tendo em vista os itens acima apresentados eu, de forma livre e esclarecida, manifesto meu interesse em participar da pesquisa.

Meu nome completo, número dos documentos abaixo relacionados, assinatura e data:

R.G.: órgão expedidor (

C.P.F.:

Assinatura do entrevistado

Assinatura da pesquisadora

São Paulo, 28 de abril de 2011 
Apêndice 9 - Termo de autorização de uso de imagem de artista ministrante de oficina em sessão especial do programa educativo Interar-te do MAC USP

S_L

Faculdade de Educação

\section{AUTORIZAÇÃO PARA USO DE IMAGEM}

Pesquisa: (título provisório) Famílias no museu de arte: lazer e conhecimento - um estudo de sobre o programa Interar-te do MAC USP

Instituição: Faculdade de Educação da USP

Nível: Mestrado

Pesquisadora: Andrea Alexandra do Amaral Silva e Biella

Orientadora: $\operatorname{Prof}^{a}$ Dr $^{a}$ Rosa Iavelberg

$\mathrm{Eu}$,

R.G.:

C.P.F.: , autorizo a mestranda (FE-USP 2009/2012) Andrea

Alexandra do Amaral Silva e Biella a utilizar, para fins da pesquisa (título provisório) "Famílias no museu de arte: lazer e conhecimento - um estudo de sobre o programa Interar-te do MAC USP” e consequente dissertação de mestrado que originará, a utilizar minha imagem registrada durante as atividades do Programa Interar-te do MAC-USP, das quais participei como artista ministrante convidada em agosto de 2008. Estou ciente de que após publicação da dissertação, será autorizada sua reprodução parcial ou completa para fins de pesquisa e ensino, não comerciais.

Assinatura

São Paulo, __ de novembro de 2011

Dados para contato: 